\title{
Stress bij ouders van een verstandelijk gehandicapt kind : evaluatie van thuiszorg
}

Citation for published version (APA):

van Berkum, H. W. (1992). Stress bij ouders van een verstandelijk gehandicapt kind : evaluatie van thuiszorg. [Doctoral Thesis, Maastricht University]. Swets \& Zeitlinger.

https://doi.org/10.26481/dis.19920610hb

Document status and date:

Published: 01/01/1992

DOI:

10.26481/dis.19920610hb

Document Version:

Publisher's PDF, also known as Version of record

\section{Please check the document version of this publication:}

- A submitted manuscript is the version of the article upon submission and before peer-review. There can be important differences between the submitted version and the official published version of record.

People interested in the research are advised to contact the author for the final version of the publication, or visit the DOI to the publisher's website.

- The final author version and the galley proof are versions of the publication after peer review.

- The final published version features the final layout of the paper including the volume, issue and page numbers.

Link to publication

\footnotetext{
General rights rights.

- You may freely distribute the URL identifying the publication in the public portal. please follow below link for the End User Agreement:

www.umlib.nl/taverne-license

Take down policy

If you believe that this document breaches copyright please contact us at:

repository@maastrichtuniversity.nl

providing details and we will investigate your claim.
}

Copyright and moral rights for the publications made accessible in the public portal are retained by the authors and/or other copyright owners and it is a condition of accessing publications that users recognise and abide by the legal requirements associated with these

- Users may download and print one copy of any publication from the public portal for the purpose of private study or research.

- You may not further distribute the material or use it for any profit-making activity or commercial gain

If the publication is distributed under the terms of Article $25 \mathrm{fa}$ of the Dutch Copyright Act, indicated by the "Taverne" license above, 
STRESS BUJ OUDERS VAN EEN VERSTANDELIJK GEHANDICAPT KIND EVALUATIE VAN THUISZORG

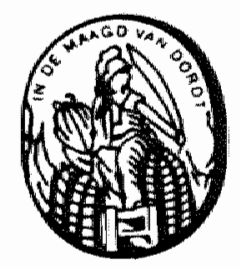

SWETS \& ZEITLINGER B.V. AMSTERDAM / LISSE 


\section{STRESS BIJ OUDERS VAN EEN VERSTANDELIJK GEHANDICAPT KIND}

\section{EVALUATIE VAN THUISZORG}

\section{PROEFSCHRIFT}

ter verkrijging van de graad van doctor

aan de Rijksuniversiteit Limburg te Maastricht, op gezag van de Rector Magnificus, Prof. Mr. M.J. Cohen,

volgens het besluit van het College van Dekanen,

in het openbaar te verdedigen op

woensdag, 10 juni 1992 om 14.00 uur

door

Hillegonda Wilhelmina van Berkum 


\section{Promotores:}

Prof. dr. J.J.C.B. Bremer

Prof. dr. G.J. Kok

Co-promotor:

Dr. J.C.H.M. Wijffels

\section{Beoordelingscommissie:}

Prof. dr. M.A. van den Hout (voorzitter)

Prof. dr. A.P. Buunk

Prof. dr. R.H. Kuijten

Prof. dr. H. Philipsen

Prof. dr. M.J. van Walleghem

Het onderzoek is mogelijk gemaakt door een subsidie van het Praeventiefonds (projectnummer 28-1435).

Het proefschrift is tot stand gekomen dankzij de Stichting Wetenschappelijk Instituut en Historisch Centrum (SWIHC) ten behoeve van de Zorg voor Geestelijk Gehandicapten. 
Opgedragen aan mijn moeder 


\section{CIP-GEGEVENS KONINKLIJKE BIBLIOTHEEK, DEN HAAG}

Berkurn, H.W. van

Stress bij ouders van een verstandelijk gehandicapt kind : evaluatie van thuiszorg / H.W. van Berkum. Amsterdam [etc.] : Swets \& Zeitlinger.

Ook verschenen in handelseditie: Amsterdam [etc.] : Swets \& Zeitlinger, 1992 - Proefschrift Maastricht. - Met lit. opg.

ISBN $90-265-1267-8$

NUGI 758

Trefw: thuiszorg ; geestelijk gehandicapte kinderen / stress ; ouders van geestelijk gehandicapte kinderen.

Omslagontwerp: Rob Molthoff

Druk omslag: Casparie, IJssellstein

Druk: Offsetdrukkerij Kanters B.V., Alblasserdam

\section{Copyright 1992, Swets \& Zeitlinger B.V. Amsterdam/Lisse}

Alle nechten voorbehouden. Niets uit deze uitgave mag worden verveelvoudigd, opgeslagen in een geautomatiseerd gegevensbestand, of openbaar gemaakt, in enige vorm of op enige wijze, hetzij elek-

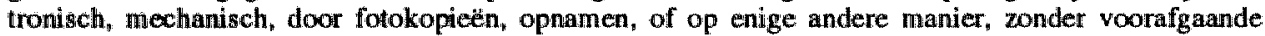
schriftelijke toestemming van de uitgever.

Voor zover het maken van kopieèn uit deze uitgave is toegestaan op grond van artikel 16B Auteurswet $1912 \mathrm{j}^{\circ}$ het Besluit van 20 juni 1974 St.b.351, zoals gewijzigd bij het Besluit van 23 augustus 1985, St.b. 471 en artikel 17 Auteurswet 1912, dient men de daarvoor wettelijk verschuldigde vergoedingen te voldoen aan de Stichting Reprorecht (Postbus 882, $1180 \mathrm{AW}$ Amstelveen). Voor het owernemen van gedeelte(n) uit deze uitgave in bloemlezingen, readers en andere compilatiewerken (artikel 16 Auteurswet 1912) dient men zich tot de uitgever te wenden.

All rights meserved. No part of this publication may be reproduced, stored in a retrieval system, or transmitted, in any form or by any means, electronic, mechanical, photocopying, recording, or otherwise, without the prior written pernnission of the publisher.

ISBN $\quad 9026512678$

NUGI 758 
Voorwoord

\section{$1 \quad$ Inleiding}

1.1 Stress bij ouders van een kind met een verstandelijke handicap 12

1.2 Begeleiding van gezinnen met een verstandelijk gehandicapt kind 13

1.3 Vraagstellingen van het onderzoek 15

2 De stresstheorie van R.S. Lazarus $\quad 17$

$\begin{array}{lll}2.1 & \text { Cognitieve appraisal } & 17\end{array}$

2.2 Coping 19

$\begin{array}{ll}2.3 & \text { Hulpbronnen } \\ 2.32\end{array}$

2.3.1 Utilitaire bronnen $\quad 22$

$\begin{array}{ll}\text { 2.3.2 Persoonlijkheidskenmerken } & 22\end{array}$

$\begin{array}{ll}2.3 .3 & \text { Sociale steun } \\ 2.3 .4 & 23\end{array}$

2.3.4 Besluit: Hulpbronnen 26

$\begin{array}{lll}2.4 & \text { Uitkomsten van het stressproces } & 27\end{array}$

$2.5 \quad$ Besluit: De stresstheorie van R.S. Lazarus 30

$3 \quad$ Stressmodellen bij ouders van een verstandelijk gehandicapt kind 31

3.1 Stress 31

3.2 Het basismodel 32

3.2.1 Kenmerken van het verstandelijk gehandicapte kind 33

$\begin{array}{lll}3.2 .2 & \text { Kenmerken van de ouders } & 37\end{array}$

$\begin{array}{lll}3.2 .3 & \text { Kenmerken van de andere kinderen } & 38\end{array}$

3.2.4 Besluit: Het basismodel $\quad 40$

3.3 Het copingmodel $\quad 40$

3.4 Het sociale-steunmodel $\quad 43$

3.5 Besluit: Stressmodellen 46

4 Ontwikkeling van gezinsbegeleiding 49

4.1 De Conferentie Gezinsbegeleiding (1977) 49

$4.2 \quad$ Overheidsbeleid na $1977 \quad 53$

4.3 Zorg- en dienstverlening aan gezinnen met een verstandelijk 59 gehandicapt kind anno 1991

4.4 Besluit: Ontwikkeling van gezinsbegeleiding 65

$5 \quad$ Hulpvormen ter begeleiding van het gexin 67

$\begin{array}{lll}5.1 & \text { Praktisch Pedagogische Gezinsbegeleiding } & 67\end{array}$

$\begin{array}{lll}5.2 & \text { Praktische Thuishulp } & 71\end{array}$

$\begin{array}{lll}5.3 & \text { Weekendopvang } & 75\end{array}$

5.4 Samenvatting: Hulpvormen ter begeleiding van het gezin 79

$6 \quad$ Methode en instrumentontwikkeling 81

$\begin{array}{lll}6.1 & \text { Vragenlijst } & 81\end{array}$ 
6.1.1 Algemeen gedeelte $\quad 81$

$\begin{array}{lll}6.1 .2 & \text { Specifiek gedeelte } & 88\end{array}$

6.2 Procedure, respondenten en respons $\quad 89$

6.3 Analyses en designs 91

6.3.1 Theoretische vraagstelling: Beschrijving van de analyses 91

6.3.2 Evaluatieve vraagstellingen: Beschrijving van de analyses 96

7 Resultaten I: Toetsing van de stressmodellen 101

7.1 Het basismodel (schema 6.1) 101

7.1.1 Stresserende kenmerken van het verstandelijk gehandicapte kind 103

$\begin{array}{ll}7.1 .2 & \text { Predictie van de concrete problemen van ouders } \\ 705\end{array}$

7.1.3 Predictie van het psychosomatisch onwelbevinden van ouders 108

$\begin{array}{lll}7.2 & \text { Het copingmodel (schema 6.2) } & 110\end{array}$

$\begin{array}{lll}7.3 & \text { Het sociale-steunmodel (schema 6.3) } & 114\end{array}$

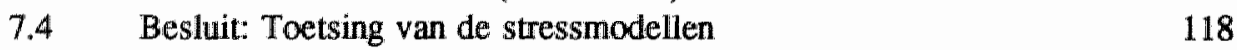

$\begin{array}{lll}7.4 .1 & \text { Samenvatting van de resultaten } & 118\end{array}$

7.4.2 Implicaties voor de hypotheses ten aanzien van de hulpverlening 120

8 Resultaten II: Hulpvragers en hulpvragen 123

$\begin{array}{lll}\text { 8.1 De controlegroep } & 123\end{array}$

8.2 Praktisch Pedagogische Gezinsbegeleiding 125

$\begin{array}{ll}\text { 8.2.1 Beschrijving van de PPG-gezinnen } & 125\end{array}$

$\begin{array}{ll}8.2 .2 & \text { Toetsing van de hypotheses } \\ 8 & 125\end{array}$

$\begin{array}{lll}8.2 .3 & \text { Hulpvragen en subgroepen } & 128\end{array}$

8.2.4 Samenvatting: Hulpvragers en hulpvragen bij PPG 130

$\begin{array}{lll}\text { 8.3 Praktische Thuishulp } & 130\end{array}$

$\begin{array}{ll}\text { 8.3.1 Beschrijving van de PT-gezinnen } & 131\end{array}$

8.3.2 Toetsing van de hypotheses 131

$\begin{array}{ll}\text { 8.3.3 Hulpvragen en subgroepen } & 132\end{array}$

8.3.4 Gewenste frequentie 133

8.3.5 Samenvatting: Hulpvragers en hulpvragen bij PT 133

$\begin{array}{lll}8.4 & & 134\end{array}$

8.4.1 Beschrijving van de WO-gezinnen 134

8.4.2 Toetsing van de hypotheses 135

$\begin{array}{ll}\text { 8.4.3 Hulpvragen en subgroepen } & 136\end{array}$

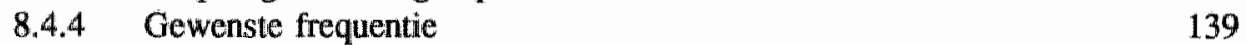

8.4.5 Samenvatting: Hulpvragers en hulpvragen bij WO 139

8.5 Besluit: Hulpvragers en hulpvragen bij thuiszorg 140

9 Resultaten III: Effecten en oordelen 141

$\begin{array}{lll}9.1 & \text { De controlegroep } & 141\end{array}$

9.2 Praktisch Pedagogische Gezinsbegeleiding 143

9.2.1 Beschrijving van de PPG-groep in de nameting 143

$\begin{array}{lll}\text { 9.2.2 Effecten } & 143\end{array}$

9.2.2.1 Effecten voor de totale PPG-groep 144

$\begin{array}{ll}\text { 9.2.2.2 Effecten per subgroep } & 145\end{array}$

9.2.2.3 Samenvatting: Effecten van PPG 147

$\begin{array}{lll}9.2 .3 \text { Oordelen } & 148\end{array}$ 
$\begin{array}{ll}\text { 9.2.3.2 Inhoud } & 149\end{array}$

$\begin{array}{ll}\text { 9.2.3.3 Algemene satisfactie } & 152\end{array}$

9.2.3.4 Samenvatting: Oordelen over PPG 153

9.3 Praktische Thuishulp 154

9.3.1 Beschrijving van de PT-groep in de nameting 154

9.3.2 Effecten 155

9.3.3 Oordelen 156

9.3.3.1 Vormgeving 156

$\begin{array}{ll}\text { 9.3.3.2 Inhoud - } & 157\end{array}$

$\begin{array}{ll}\text { 9.3.3.3 Algemene satisfactie } & 158\end{array}$

9.3.4 Samenvatting: Effecten van en oordelen over PT 158

$\begin{array}{lll}9.4 & \text { Weekendopvang } & 158\end{array}$

9.4.1 Beschrijving van de WO-groep in de nameting 158

$\begin{array}{lll}9.4 .2 & \text { Effecten } & 159\end{array}$

9.4.2.1 Effecten voor de totale WO-groep 159

$\begin{array}{lll}\text { 9.4.2.2 Effecten per subgroep } & 160\end{array}$

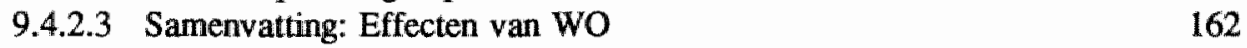

$\begin{array}{lll}\text { 9.4.3 Oordelen } & 162\end{array}$

$\begin{array}{lll}\text { 9.4.3.1 Vormgeving } & 162\end{array}$

$\begin{array}{lll}\text { 9.4.3.2 Inhoud } & 165\end{array}$

$\begin{array}{ll}\text { 9.4.3.3 Algemene satisfactie } & 166\end{array}$

9.4.3.4 Samenvatting: Oordelen over WO 167

9.5 Besluit: Effecten van en oordelen over thuiszorg 167

10 Discussie en aanbevelingen 169

10.1 Stress bij ouders van een kind met een verstandelijke handicap $\quad 170$

$\begin{array}{lll}10.2 & \text { Evaluatie van thuiszorg } & 177\end{array}$

10.2.1 Praktisch Pedagogische Gezinsbegeleiding 178

$\begin{array}{lll}\text { 10.2.2 Praktische Thuishulp } & 182\end{array}$

$\begin{array}{lll}10.2 .3 & \text { Weekendopvang } & 184\end{array}$

$\begin{array}{lll}\text { 10.2.4 Besiuit: Evaluatie van thuiszorg } & 188\end{array}$

$\begin{array}{lr}\text { Samenvatting } & 189\end{array}$

$\begin{array}{ll}\text { Summary } & 195\end{array}$

$\begin{array}{ll}\text { Literatuur } & 201\end{array}$

Bijlagen $\quad 213$

A Tabellen instrumentontwikkeling (Paragraaf 6.1.1) 213

$\begin{array}{lll}\text { B } & \text { Brieven aan de ouders (Paragraaf 6.2) } & 219\end{array}$

C Tabellen stressmodellen (Hoofdstuk 7) 225

D Tabellen voormeting (Hoofdstuk 8) 231

E Tabellen nameting (Hoofdstuk 9) 233

F Lijst met afkortingen 235 
Onderzoek doen naar de stress van ouders van een kind met een verstandelijke handicap heeft meer voor mij betekend dan ik bij de start van deze studie kon voorzien. De gesprekken met de ouders die mij tot twee keer toe in hun gezin hebben willen ontvangen om mij over de vreugde en het verdriet in hun leven te vertellen, vormen niet alleen de basis voor dit proefschrift: zij hebben ook een diepe indruk op mij gemaakt. Deze ouders wil ik als eerste danken yoor de openhartigheid waarmee zij mij te woord stonden. Tevens wil ik alle hulpverleners en directeuren van scholen en dagverblijven danken voor hun medewerking die mij in de gelegenheid stelde dit onderzoek uit te voeren.

Mijn beide promotoren en mijn co-promotor dank ik voor de plezierige en leerzame samenwerking die ik met hen mocht ervaren. Prof. dr. J. Bremer dank ik voor de vlotte, nauwgezette en geruststellende wijze waarop hij mij tijdens alle fasen van het onderzoek heeft begeleid. De veelal summiere opmerkingen van prof. dr. Gerjo Kok zijn altijd bruikbaar gebleken. Dr. J. Wijffels ben ik erkentelijk voor het feit dat hij de gedachte om de Experimentele Weekendopvang op de Severinusstichting met wetenschappelijk onderzoek te begeleiden, in daden heeft weten om te zetten. Tijdens het onderzoek heeft hij mij voortdurend met wijze raad bijgestaan.

Gedurende de gehele onderzoeksperiode heb ik voorts veel steun ontvangen van Dr. Frans Siero. De waardevolle gesprekken over methodologische en andere facetten van de studie waren altijd verhelderend en inspireerden mij telkens weer tot nieuwe ideeën. De opmerkingen van de leden van de Beoordelingscommissie zijn het proefschrift eveneens ten goede gekomen.

De begeleidingscommissie, ingesteld door de Vereniging Regionaal Overlegorgaan Zorg voor Geestelijk Gehandicapten Zuidoost-Brabant, heeft een belangrijke bijdrage aan het onderzoek geleverd. Mevr. J.H. van Lokven (voorzitter), mevr. L. Bouw, mevr. S. Dijkstra, dhr. R. van Engelen, mevr. R. v.d. Eijnde, mevr. E. van Soest, dhr. G. ten Theije Boonkkamp en mevr. B. Verheijen dank ik voor hun enthousiaste en kritische opmerkingen, met name tijdens de fase waarin de vragenlijst geconstrueerd werd en tijdens de fasen waarin de data verwerkt werden.

De Severinusstichting ben ik erkentelijk voor de prettige werkomgeving die men mij gedurende de onderzoeksperiode bood. Mevr. A. Habraken en mevr. I. Wilbrink dank ik voor de accurate secretariële ondersteuning die zij mij gedurende deze tijd boden; zij namen mij hiermee een groot gedeelte van mijn werk uit handen. 
Bernadette Verheijen en Els van Soest dank ik voor de voortreffelijke manier waarop zij zich gekweten hebben van hun taken als paranimfen. De ongekende aandacht waarmee Ben mij heeft omringd, is voor mij en voor het voltooien van mijn werk onmisbaar geweest. Aangezien er tenslotte geen woorden zijn om mijn moeder te danken voor de onvoorwaardelijke interesse die zij altijd in mij heeft gehad, draag ik dit boek aan haar op. 


\section{Inleiding}

Ouders van een kind met een verstandelijke handicap zien zich vaak geconfronteerd met problemen van uiteenlopende aard, zoals emotionele, praktische, relationele, financiële en pedagogische problemen. Meestal komen ouders zelf tot aanvaardbare oplossingen voor deze moeilijkheden. Soms wordt de problematiek echter zo ernstig en hun leven met het verstandelijk gehandicapte kind zo belastend, dat hun geestelijke en lichamelijke draagkracht overschreden wordt of dreigt te worden.

Tot op heden is uit studies geen helder beeld verkregen van de factoren die van belang zijn in het ontstaan of voortbestaan van stress bij ouders van een kind met een verstandelijke handicap. Een belangrijke reden voor dit gebrek aan duidelijkheid ligt in het feit dat onderzoekers deze ouders lange tijd als een homogene groep hebben beschouwd en hun psychosomatisch onwelbevinden als een weliswaar pathologische maar vrijwel onvermijdelijke reactie op de geboorte van een kind met een verstandelijke handicap (Cummings, 1976; Cummings, Bayley \& Rie, 1966; Erickson, 1969; Miller \& Keirn, 1978). Pas sinds de jaren zeventig trachten onderzoekers inzicht te krijgen in de redenen voor de in de klinische praktijk te constateren verschillen in stress tussen ouders van een kind met een verstandelijke handicap. Zij laten zich hierbij vooral inspireren door moderne stresstheorieen (Byme \& Cunningham, 1985; Crnic, Friedrich \& Greenberg, 1983). In 1.1 wordt de meest invloedrijke theorie over stress en coping, namelijk de transactionele, cognitief-fenomenologische theorie van Richard S. Lazarus, kort aan de orde gesteld, omdat de eerste doelstelling van het onderzoek waarvan dit proefschrift de bevindingen presenteert, stress bij ouders van een kind met een verstandelijke handicap betreft.

Als ouders van een verstandelijk gehandicapt kind dat wensen, kunnen zij hulp krijgen bij het leren hanteren of oplossen van hun problemen. Recentelijk zijn hulpvormen ontwikkeld die zich in eerste instantie richten op begeleiding en 
ondersteuning van het gezin, met name de ouders, en niet op begeleiding van het gehandicapte kind. Deze hulpvormen beogen in het algemeen de balans te bevorderen tussen de draagkracht van ouders en de draaglast die het leven met een verstandelijk gehandicapt kind kan meebrengen. Deze vormen van hulp zijn zowel in als buiten de specifieke zorg- en dienstverlening ten behoeve wan mensen met een verstandelijke handicap ontstaan. De tweede vraagstelling van het onderhavige onderzoek heeft betrekking op de evaluatie van drie van deze wormen van gezinsbegeleiding c.q. thuiszorg. Deze worden in 1.2 kort beschireven na een introductie in de achtergronden van het ontstaan van dit soort vormen van hulp.

\subsection{Stress bij ouders van een kind met een verstandelijke handicap}

Richard S. Lazarus ontwikkelde een transactionele en cognitief-fenomenologische theorie over emoties, stress en coping. De term "transactioneel" refereert aan het feit dat mens en omgeving voortdurend op elkaar inwerken. "Transactioneel" impliceert een nieuw abstractieniveau, waarin mens en omgeving niet meer los van elkaar gezien kunnen worden en een nieuwe eenheid vormen. De wijze waarop transacties tussen mensen en hun omgeving plaatsvinden, duidt Lazarus aan met het begrip "cognitief-fenomenologisch". In zijn visie zijn mensen cognitieve, evaluerende wezens die voortdurend betekenis verlenen aan omgevingsstimuli. Deze betekenisverlening gaat vooraf aan de emotionele en gedragsmatige reacties van mensen op hetgeen hen overkomt c.q. op de situatie waarin zij zich bevinden (Lazanus, Averill \& Opton, 1970; Lazarus, Kanner \& Folkman, 1980; Lazarus \& Launier, 1978).

Lazarus vat "stress" op als een bepaalde relatie tussen mens en omgeving. De vraag die hij in zijn theorie tracht te beantwoorden, is: wat maakt een specifieke relatie tot een stressvolle relatie? Volgens Lazarus intervenièren twee processen tussen hetgeen iemand overkomt c.q. de objectieve situatie waarin iemand zich bevindt en zijn of haar uiteindelijke stressreacties: cognitieve appraisall en coping. "Cognitieve appraisal" verwijst naar een complex proces dat bepaalt op wellke wijze en in welke mate een specifieke situatie stressvol is. Men evalueert tijdens dit proces zowel het belang van de situatie voor het persoonlijk welbevinden als de mogelijkheden die men op dat moment heeft om deze specifieke omstandigheden het hoofd te bieden.

"Coping" refereert aan de gedragsmatige, cognitieve en emotionele manieren waarop mensen omgaan met stressvolle gebeurtenissen of omstandigheden. Deze manieren zijn afhankelijk van de uitkomsten van het specifieke cognitieve appraisalproces en van algemene en relatief stabiele hulpbronnen waarover men beschikt, zoals persoonlijkheidskenmerken, utilitaire bronnen en steun uit de sociale omgeving. Er is in Lazarus' visie sprake van psychologische stress wanneer een specifieke transactie met de orngeving in de ogen van de persoon in kwestie de hulpmiddelen die hem of haar ter beschikking staan, te zeer belast of overschrijdt en wanneer deze situatie zijn of haar welbevinden bedreigt (Lazarus \& Folkman, 1984).

Hoofdstuk 2 gaat nader in op de theorie van Lazarus en op de resultaten van de talrijke studies die op deze visie gebaseerd zijn. Ook onderzoekers op het gebied 
van stress bij ouders van een kind met een verstandelijke handicap hebben zich llaten inspireren door Lazarus' stresstheoric. De opvatting dat stress een relationeel begrip is dat betrekking heeft op een discrepantie die iemand ervaart tussen de eisen van zijn of haar omgeving of zichzelf en zijn of haar vaardigheden, behoeften en mogelijkheden om aan deze eisen tegemoet te komen, suggereert dat stress bij ouders van een verstandelijk gehandicapt kind een individuele aangelegenheid is. Het leven met een verstandelijk gehandicapt kind is met andere woorden niet per se belastend, zoals de psychopathologische benadering aannam, maar potentieel stressvol.

Studies onder ouders van een verstandelijk gehandicapt kind bevatten aanwijzingen die erop duiden dat de stress van deze ouders afhankelijk is van kenmerken van het gehandicapte kind, zoals zijn of haar leeftijd, verstandelijk niveau van functioneren en gedragsproblematiek, kenmerken van de ouders, zoals hun zelfwaardering en copingstijlen, en kenmerken van de omgeving, zoals het aantal andere kinderen in het gezin en de steun die ouders uit hun sociale omgeving ontvangen. Het stressonderzoek onder ouders van een kind met een verstandelijke handicap staat echter nog in de kinderschoenen: er bestaat nog geen "succint, truly comprehensive model ... through which one can develop an empirical understanding of families of retarded children" (Cmic et al., 1983, p. 126).

In hoofdstuk 3 worden drie stressmodellen opgesteld die verklaringen trachten te bieden voor het feit dat sommige ouders hun leven met het verstandelijk gehandicapte kind als meer belastend ervaren dan andere ouders: het zogeheten basismodel, het copingmodel en het sociale-steunmodel. Lazarus' visie op stressprocessen dient bij deze modellen als theoretisch uitgangspunt, dat wordt aangevuld met uitkomsten van studies naar stress in het algemeen en van studies onder ouders van een (verstandelijk) gehandicapt of emstig ziek kind in het bijzonder.

\subsection{Begeleiding van gezinnen met een verstandelijk gehandicapt kind}

De Nederlandse zwakzinnigenzorg heeft een enorme ontwikkeling doorgemaakt sinds ds. Van Koetsveld in 1855 de eerste "idiotenschool" oprichtte in Den Haag en deze drie jaar later omzette in het eerste "gesticht voor idioten". Vór de Tweede Wereldoorlog begon de zorg voor geestelijk gehandicapten zich voorzichtig als een aparte zorgvorm te ontwikkelen, naast de zorg voor andere groepen hulpbehoevenden. $\mathrm{Na} 1945$ werden de voorzieningen die voordien veelal vanuit het particulier initiatief waren opgericht, verder uitgebreid en beter over het land gespreid. Het ging hierbij om woonvoorzieningen, scholen voor buitengewoon lager onderwijs (BLO) en nazorg voor oud-leerlingen van deze scholen. Deze snelle en forse volumegroei vond mede plaats onder druk van de ouders die zich na 1945 in ouderverenigingen organiseerden. $\mathrm{Zij}$ werden in hun roep om meer en betere voorzieningen onder andere gesteund door de gespecialiseerde maatschappelijk werkenden die na de oorlog hun intrede deden in de Sociaal Pedagogische Diensten (SPD), waartoe de nazorg voor oud-BLO-leerlingen was uitgegroeid (Kingma, 1984). 
Nog tijdens de explosieve naoorlogse toename in het aantal intramurale voorzieningen voor mensen met een verstandelijke handicap voelden steeds minder ouders ervoor hum verstandelijk gehandicapte kind in een dergelijke institutionele woonvoorziening te plaatsen. Ouders kregen vanaf de jaren zestig ook meer mogelijkheden om hun gehandicapte kind langer thuis te houden omdat nieuwe voorzieningen voor dagopvang, de kinderdagverblijven (KDV) en de dagverblijven voor ouderen (DVO), een gedeelte van de dagelijkse verzorging en opvoeding van het kind uit hun handen namen (Gunters, 1985; Gunters \& De Jong, 1987). Wellicht droegen ook de algehele democratiseringsbeweging in de zestiger jaren en de opkomende normalisatie- en integratiegedachten in de zorg ten behoeve van mensen met een verstandelijke handicap ertoe bij dat een toenemend aantal ouders hun gehandicapte kind zo lang als dat mogelijk was in hun eigen gezin wilde grootbrengen.

De zorg- en dienstverlening was in de zestiger en zeventiger jaren echter niet afgestemd op de problemen en de hulpvragen van ouders van een thuis wonend kind met een verstandelijke handicap. Ouders, hulpverleners, wetenschappers en beleidmakers brachten dit in 1977 tijdens de Conferentie Gezinsbegeleiding onder de aandacht van de overheid. Deze conferentie werd in Noordwijkerhout georganiseerd onder auspicièn van het Nationaal Orgaan Zwakzinnigenzorg, de Stichting Federatie van Ouderverenigingen en het Nederlands Genootschap ter Bestudering van de Zwakzinnigheid en de Zwakzinnigenzorg. De conferentie is een mijlpaal in de zwakzinnigenzorg geworden en de term "gezinsbegeleiding" een sleutelwoord voor tal van vemieuwingen in de zorg- en dienstverlening aan mensen met een verstandelijke handicap en hun directe omgeving.

De overheid nam de noden van ouders die thuis een kind met een verstandelijke handicap trachten groot te brengen, serieus. Een belangrijke reden daarvoor ligt in het feit dat de knelpunten in de zwakzinnigenzorg die men tijdens de Conferentie Gezinsbegeleiding signaleerde, in grote mate overeenkwamen met de oorzaken van de ondoelmatige en ontoereikende dienstverlening in de zorg voor de gezondheid en het welzijn van de bevolking in haar geheel. Deze problemen waren reeds drie jaar voór de conferentie door toenmalig staatssecretaris Hendriks van Volksgezondheid en Milieuhygiëne in de structuurnota Gezondheidszorg (1974) naar voren gebracht. Zij betroffen met name de onvoldoende samenhang en samenwerking tussen voorzieningen, de onevenwichtigheden in het voorzieningenstelsel, een onoverzichtelijke financieringsstructuur en een gemis aan beheersinstrumenten voor de kostenontwikkeling.

Ook enkele maatregelen die men tijdens de Conferentie Gezinsbegeleiding voorstelde om de zwakzinnigenzorg aan te passen aan de veranderde hulpvragen van ouders, stemden overeen met de voorstellen in de structuurnota om de problemen in de gezondheidszorg in haar geheel op te lossen. Men bepleitte vooral een grotere nadruk op het eerste echelon in de zorg en regionalisatie en regionale samenwerking tussen hulpverlenende instellingen in de zorg aan mensen met een verstandelijke handicap. De Conferentie Gezinsbegeleiding en de nawerking ervan moeten dan ook mede worden bezien in het licht van de herstructureringen die vanaf de eerste 
ingreep van de overheid in de structuur van de gezondheidszorg in thaar geheel hebben geleid tot concepten als substitutie, thuiszorg en zorg op maat.

Hoofdstuk 4 gaat nader in op de Conferentie Geainsbegeleiding en op de overheidsmaatregelen die ertoe moesten bijdragen dat ouders meer mogelijkheden zouden krijgen om hun verstandelijk gehandicapte kind in het eigen gezin groot te brengen. Door de bemoeienissen wan overheid, ouders en hulpverleners zijn sinds het eind van de jaren zeventig onder andere enige lacunes in de zwakzinnigenzorg opgeheven door de ontwikkeling van nieuwe hulpvormen, die beogen het evenwicht te bevorderen tussen de draagkracht en de draaglast van ouders van een thuis wonend kind met een verstandelijke handicap (Federatie van Ouderverenigingen, 1980; Landelijke Commissie Gezinsbegeleiding, 1982). De drie belangrijkste hiervan zijn Praktisch Pedagogische Gezinsbegeleiding (PPG), Praktische Thuishulp (PT) en Weekendopvang (WO).

Praktisch Pedagogische Gezinsbegeleiding tracht de draagkracht van ouders te doen toenemen door hun hulp te bieden bij vragen omtrent de omgang met en de opvoeding van het gehandicapte kind. Praktische Thuishulp tracht de balans in de gezinnen te optimaliseren door hulp te bieden bij problemen van praktische aard. Weekendopvang tracht de draaglast van de gezinnen te reduceren door het verstandelijk gehandicapte kind zo nu en dan een weekend uit het gezin te nemen en in een vertrouwde omgeving te laten logeren. PPG is sinds het eind van de jaren tachtig in het reguliere beleid van het ministerie van Welzijn, Volksgezondheid en Cultuur ingepast. Praktische Thuishulp is sinds begin jaren negentig bij de eerste lijns gezondheidszorg ondergebracht. Weekendopvang is nog in afwachting van de herzieningen binnen de zorg voor verstandelijk gehandicapten die naar verwachting in de loop van de jaren negentig hun beslag zullen krijgen.

In hoofdstuk 5 worden de organisatie, doelstelling, doelgroepen en werkwijze van Praktisch Pedagogische Gezinsbegeleiding, Praktische Thuishulp en Weekendopvang nader beschreven. Aangezien deze drie hulpvormen in de onderhavige studie worden geèvvalueerd, zijn op basis van deze beschrijvingen tevens hypotheses opgesteld ten aanzien van de kenmerken van de gezinnen die deze achtereenvolgende hulpvormen aanvragen en ten aanzien van de effecten van de hulp op de stress van de ouders en de determinanten daarvan.

\subsection{Vraagstellingen van het onderzoek}

Het onderzoek waarvan dit proefschrift de uitkomsten weergeeft, kent twee vraagstellingen. De eerste is theoretisch van aard: Wat zijn de determinanten van de stress van ouders van een kind met een verstandelijke handicap? In hoofdstuk 6 wordt beschreven op welke wijze de exploratieve verklaringsmodellen uit hoofdstuk 3 zijn getoetst. De bevindingen van deze analyses worden in hoofdstuk 7 weergegeven. 
De tweede vraagstelling betreft de evaluatie van Praktisch Pedagogische Gezinsbegeleiding, Praktische Thuishulp en Weekendopvang. Deze vraagstelling heeft vier subvraagstellingen:

(1) Wat zijin de kenmerken van de gezinnen die PPG, PT respectievelijk WO aanvragen?

(2) Met welke hulpura(a)g(en) c.q. om welke reden(en) vragen ouders PPG, PT respectievelijk WO aan?

(3) Wat zijn de effecten van PPG, PT respectievelijk WO op de stress van ouders en de determinanten daarvan?

(4) Hoe beoordelen de ouders PPG, PT respectievelijk WO?

Na een bespreking in hoofdstuk 6 van de wijze waarop deze evaluatieve subvraagstellingen zijn getoetst, geeft hoofdstuk 8 de bevindingen weer van de analyses ten aanzien van de twee eerste subvraagstellingen en hoofdstuk 9 die van de twee laatste. Met een discussie over de methodologische problemen in deze studie en met conclusies en aanbevelingen naar aanleiding van de bevindingen van het onderzoek wordt het proefschrift in hoofdstuk 10 afgerond. 


\section{De stresstheorie van R.S. Lazarus}

In hoofdstuk 2 wordt nader ingegaan op de transactionele, cognitief-fenomenologische theorie over emoties, stress en coping van Richard S. Lazarus (zie 1.1). In 2.1 $t / m 2.4$ komen de belangrijkste elementen uit deze theorie aan de orde: cognitieve appraisal, coping, hulpbronnen en de uitkomsten van het stressproces. Tevens worden onderzoeksresultaten besproken die betrekking hebben op deze onderdelen van de theorie.

\subsection{Cognitieve appraisal}

"Cognitive appraisal is a process through which people evaluate both the significance of a specific ... encounter for their well-being (primary appraisal) and the options for coping (secundary appraisal)" (Folkman \& Lazarus, 1986, p. 108). Tijdens het primaire appraisalproces evalueert men of een bepaalde gebeurtenis of situatie irrelevant, heilzaam of stressvol is voor het persoonlijk welbevinden. Een stressvolle situatie kan een verlies inhouden, een uitdaging zijn of een bedreiging vormen (Lazarus, Kanner \& Folkman, 1980). Bij deze evaluatie kunnen verschillende zaken op het spel staan, zoals het zelfrespect, de geestelijke of lichamelijke gezondheid van de persoon in kwestie of van iemand om wie hij of zij veel geeft, ambities op het werk of financièle zaken (Folkman, Lazarus, Dunkel-Schetter, DeLongis \& Gruen, 1986).

Hoewel "secundaire appraisal" een andere connotatie heeft, kan deze vorm van appraisal zowel voorafgaan aan de primaire evaluatie van een gebeurtenis of situatie als deze in de tijd opvolgen. In feite is er sprake van een wederzijdse beinvloeding van beide processen. Het verschil betreft het object van evalluatie: tijdens het secundaire appraisalproces evalueert men de situatie of gebeurtenis ten opzichte van de copingstrategieën en hulpbronnen waarover men beschikt (Lazarus \& Launier, 1978). 
In hel secundaire appraisalproces: (a) gaat men na welke copingstrategieën men heeft om het probleem of de situatie het hoofd te bieden; (b) schat men de kans in dat een (combinatie van) copingstrategie(ën) het gewenste effect bereikt (respons of outcome efficacy); en (c) schat men de kans in dat men zelf in staat is deze copingstrategieèn effectief uit te voeren (self-efficacy; Bandura, 1977, 1986; Lazarus \& Folkman, 1984).

Reappraisal, het derde onderdeel van cognitieve appraisal, verwijst naar een feedbackproces (Coyne \& Lazarus, 1981) en is in de theorie opgenomen om het cyclische karakter en de continuiteit van de transacties tussen mens en omgeving te benadrukken. Primaire en secundaire appraisal leiden tot een gewijzigde relatie, waarin het appraisalproces opnieuw in werking treedt. Dit hemieuwde proces verschilt in essentie niet van appraisal: reappraisal refereert aan een appraisalproces dat volgt op een eerdere appraisal in dezelfde situatie.

Met zijn nadruk op cognitieve elementen legt Lazarus een verbinding tussen de stimulus- en de responsbenaderingen die in de jaren vijftig en zestig ten aanzien van stress ontwikkeld werden. Stimulusbenaderingen classificeren gebeurtenissen en omstandigheden (stressoren) naar de mate van aanpassing die in het algemeen vereist is om deze in het normale leefpatroon in te passen. Met individuele variatie in reacties op deze stressoren wordt nauwelijks rekening gehouden: in onderzoeken waarin de relatie tussen stressoren en gezondheidsstoomissen het onderwerp van studie vormt, worden de stressoren als het ware alls externe ziekteverwekkers beschouwd. De meest bekende en invloedrijke stimulusbenadering is de "life events"-traditie (Holmes \& Masuda, 1974; Holmes \& Rahe, 1967).

Responsbenaderingen besteden weinig aandacht aan stressoren, maar concentreren zich juist op stressreacties (strains). De grondlegger van het wetenschappelijk stressonderzoek, de fysioloog Selye, vat deze lichamelijke en later ook psychische reacties op als pogingen van mensen hun evenwicht te herstellen, dat wil zeggen als verdedigingsmechanismen tegen dnuk van buitenaf (Selye, 1956, 1978). Lazarus meent dat stimulus- en responsbenaderingen beide slechts éen kant van het totale stressproces belichten. Het actieve cognitieve appraisalproces vormt de verbindende schakel tussen hetgeen iemand overkomt en zijn of haar reacties daarop. Niet de objectieve werkelijkheid, maar de wereld zoals deze wordt waargenomen door het individu, ligt ten grondslag aan zijn of haar gedrag en emoties.

Met zijn cognitieve mensvisie stond Lazarus in de jaren zestig tegenover de heersende persoonlijkheidstheorieën in de psychologie, de psychodynamische en de $($ neo -$)$ behavioristische: "mainstream psychology was still some distance from the cognitive revolution" (Lazarus \& Folkman, 1984, p. 22). Lazarus en zijn medewerkers hebben dan ook veel aandacht besteed aan de rol van cognitieve processen in het ontstaan van stressreacties. De laboratoriumstudies uit deze jaren hebben kunnen aantonen dat experimenteel gemanipuleerde variaties in cognitieve appraisal inderdaad variaties in stress- en copingreacties tot gevolg hebben (voor besprekingen van deze studies, zie: Lazarus, Averill \& Opton, 1970, 1974). 
Toen de psychologie in het algemeen en de psychosociale stresstheorieèn in het bijzonder gedurende de zestiger en zeventiger jaren een steeds grotere plaats inruimden voor cognitieve processen (zie bijvoorbeell de herformulering van het "life events"-model van Rahe \& Arthur, 1978), werd het voor Lazarus minder noodzakelijk zich diepgaand met cognitieve appraisal bezig te houden. In zijn theorievorming en in zijn onderzoeken, die zich vanaf de jaren zeventig verplaatsten naar settings buiten het laboratorium, blijft dit proces weliswaar een belangrijke rol spelen. In deze natuurlijke omgevingen kon men overigens ook aantonen dat een gedeelte van de variatie in copingstrategieën en stressreacties kan worden toegeschreven aan variaties in primaire en secundaire appraisal (Folkman \& Lazarus, 1980; McCrae, 1984; Rippetoe \& Rogers, 1987). Vanaf de zeventiger jaren richt Lazarus zijn blik echter meer systematisch op de theoretische definiëring van het begrip coping en in het verlengde daarvan op de ontwikkeling van een instrument om coping te meten.

\subsection{Coping}

Terwijl potentieel stressvolle omstandigheden en gebeurtenissen een onvermijdelijk aspect van het leven zijn, zijn "the ways people cope with stress ... even more important to overall morale, social functioning, and health/illness than the frequency and severity of episodes of stress themselves" (Lazarus \& Launier, 1978, p. 308).

"Coping" is een veel gebruikt begrip, maar de conceptualisering en de operationalisatie ervan vormen nog steeds onderwerpen van discussie. Na hun analyse van recente definities van coping concluderen Tellegen en Winnubst (1986) bijvoorbeeld dat deze nogal uiteenlopen en dat verschillende in hun ogen essentielle aspecten van coping in veel definities onvermeld blijven. Alleen de definities van Lazarus en degenen die zich op zijn werk baseren, voldoen aan de meeste van de door hen opgestelde criteria. Lazarus definieert coping als "constantly changing cognitive and behavioral efforts to manage specific external and/or internal demands that are appraised as taxing or exceeding the resources of the person" (Lazarus \& Folkman, 1984, p. 141).

De definitie van Lazarus en Folkman verwijst naar bewuste, planmatige en op het probleem gerichte coping, naar het reguleren van emoties en naar vermijding, acceptatie van de situatie en een afwachtende houding. De definitie verwijst voorts naar het feit dat mensen beschikken over een repertoire van handelingen en cognities in hun confrontatie met stressvolle omstandigheden. De definitie verwart coping niet met de uitkomsten ervan. Een aspect dat volgens Tellegen en Winnubst (1986) in het algemeen verwaarloosd wordt, komt in de definitie van Lazarus en Folkman echter evenmin aan de orde. Coping wordt geconceptualiseerd als een samenstel van ad hoc reacties. Het aanpassende vermogen van coping op de langere termijn, het preventieve aspect van coping, wordt zelden in definities opgenomen.

Essentieel in de definitie van Lazarus en Folkman is het feit dat coping als een dynamisch proces wordt beschouwd. Hun zogeheten "microanalytische studies" be- 
treffen dan ook de manieren waarop mensen in werkelijkheid omgaan met een specifieke situatie of gebeurtenis, manieren die kunnen veranderen naarmate de situatie zich ontwikkelt. Lazarus en Folkman zetten zich hiermee af tegen de op de psychoanalyse gebaseerde theorievorming, die coping in structurelle termen, als "trail", beschrijft. Coping verwijst dan naar relatief stabiele kenmerken wan personen, die moeten voorspellen mel welke afweermechanismen bepaalde "soorten" mensen, bijvoorbeeld verdringers of vermijders, zich te weer stellen tegen (bepaalde soorten) situaties (Gleser \& Ihilevich, 1969; Plutchik, Kellerman \& Conte, 1979; Vaillant, 1971, 1977). Een dergelijke statische definitie en de unidimensionele meetinstrumenten die erop gebaseerd zijn, doen volgens Lazarus geen recht aan de complexiteit en variabiliteit van copingresponsen in specifieke stressvolle situaties.

De microanalytische benadering van Lazarus en zijn groep van medewerkers heeft weinig navolging gevonden, onder andere vanwege het arbeidsintensieve karakter erwan en vanwege het feit dat wetenschappelijk onderzoek veelal beoogt geaggregeerde trends te voorspellen en niet tot doel heeft uitspraken te doen over enkelvoudige handelingen in concrete situaties (Van Heck \& Vingerhoets, 1989).

Microanalyses verschaffen bovendien geen inzicht in de stabiliteit van copingresponsen op de langere termijn. Het is theoretisch moeilijk te verdedigen, zoals Lazarus lange tijd heeft volgehouden, dat coping geen consistentie en stabiliteit zou kennen. Het idee dat coping alleen variabiliteit zou kennen, is nauwelijks in overeenstemming te brengen met Lazarus' theoretische model waarin coping niet alleen wordt beïnvloed door het situatie-specifieke cognitieve appraisalproces, maar ook door algemene en relatief stabiele hulpbronnen, zoals sociale klasse en persoonlijkheidskenmerken (zie 2.3). Ook is het nauwelijks denkbaar dat alleen situatie-specifieke copingstrategieën verantwoordelijk zouden zijn voor het ontstaan van verstrekkende problemen als psychosomatische klachten (zie 2.4).

In hun boek Stress, appraisal and coping (1984) relativeren Lazarus en Folkman hun eerdere uitlatingen als zou er geen stabiliteit in copingresponsen bestaan, door op te merken dat deze uitlatingen waren ingegeven door kritiek op de meting van stabiliteit en consistentie. Alleen zogeheten "macroanalyses", multidimensionele onderzoeken bij dezelfde respondenten in telkens andere stressvolle omstandigheden, kunnen volgens hen inzicht verschaffen in de mate van variabiliteit en consistentie in coping. Op basis van dit soort onderzoeken concluderen zij dat variabiliteit vooral te zien is in copingstrategieèn die gericht zijn op de oplossing van (het) specifieke proble(e)m(en). Sommige emotieregulerende copingstrategieèn, zoals positieve herwaardering van de situatie, vertonen meer consistentie en zijn dus meer persoonsgebonden (Lazarus \& Folkman, 1987).

In studies naar coping en stress zijn in de loop der jaren zeer uiteenlopende gedragingen en cognities als copingstrategieèn bestudeerd, omdat een inhoudelijke analyse van het totale copingterrein ontbreekt en er geen consensus bestaat over enkele a priori opgestelde classificatiesystemen (Billings \& Moos, 1984; Lazarus, Averill \& Opton, 1974; Lazarus \& Launier, 1978; Pearlin \& Schooler, 1982). Er lijkt overi- 
gens wel overeenstemming te bestaan over het onderscheid dat de genoemde taxonomieën maken naar: (a) het doel van coping, dat wil zeggen de functie en het object ervan, bijvoorbeeld gericht op de oplossing van het probleem, emotieregulatie of evenwichtsherstel; en (b) het soort copingactiviteit, bijvoorbeeld gedragsmatig versus cognitief, actiegenicht versus intrapsychisch, "overt" versus "covert" of actief versus passief.

In het intemationale onderzoek is meer eenheid gekomen sinds vele onderzoekers in de loop van de jaren tachtig de Ways of Coping Checklist (WCC; Folkman \& Lazarus, 1980) zijn gaan gebruiken. De WCC bestaat oorspronkelijk uit 68 items "describing a broad range of behavioral and cognitive coping strategies.... They include items from the domains of defensive coping (e.g., avoidance, intellectualization, isolation, suppression), information-seeking, problem-solving, palliation, inhibition of action, direct action, and magical thinking" (Folkman \& Lazarus, 1980, p. 224). Deze items kunnen in twee categorieèn ingedeeld worden, namelijk op het probleem gerichte en op de regulatie van emoties gerichte items. De WCC bevat acht subschalen: (a) "confrontive coping", (b) "distancing", (c) "self-control", (d) "seeking social support", (e) "accepting responsability", (f) "escape-avoidance", (g) "planful problem-solving" en (h) "positive reappraisal" (Folkman, Lazarus, DunkelSchetter, DeLongis \& Gruen, 1986).

De samenstellers van de in Nederland recentelijk ontwikkelde Utrechtse Coping Lijst (UCL; Schreurs, Tellegen \& Van de Willige, 1984; Schreurs, Van de Willige, Tellegen \& Brosschot, 1988) wekken in tegenstelling tot Lazarus en Folkman niet de indruk met hun lijst het volledige copingterrein te bestrijken. De UCL bestaat uit 47 items waarvan er 44 zijn opgenomen in zeven subschalen: (a) actief problemen aanpakken, confronteren; (b) palliatieve reactie; (c) vermijden, afwachten; (d) sociale steun zoeken; (e) depressief reactiepatroon; (f) expressie van emoties of boosheid; en (g) geruststellende en troostende gedachten. Aan deze subschalen blijken twee dimensies ten grondslag te liggen. De eerste kan omschreven worden als een reactieve, defensieve manier van omgaan met problemen, de tweede als een actieve, offensieve manier van probleemhantering (Schaufeli \& Van Dierendonck, 1992).

De WCC en de UCL overlappen elkaar gedeeltelijk in de inhoud van de copingstrategieèn. Beide lijsten bevatten meer emotieregulerende dan probleemgerichte strategieën. De UCL bevat meer intrapsychische dan actiegerichte copingstrategieèn (Van Heck \& Vingerhoets, 1989), terwijl het zoeken naar socialle steun in deze lijst de prioriteit krijgt (Schaufeli \& Van Dierendonck, 1992). Beide lijsten kunnen, afhankelijk van de instructies aan de respondenten, zowel gebruikt worden om copingstijlen in het algemeen te onderzoeken als om "coping efforts" (Meneghan, 1983) of "hanteringsgedrag" (Buunk \& Janssen, 1991) in specifieke situaties te bestuderen. 


\subsection{Hulpbronnen}

De coping- en stressreacties van mensen hangen niet uitsluitend af van situatiespecifieke processen, zoals cognitieve appraisal. Algemene en relatief stabiele hulpbronnen, "coping resources", acht Lazarus eveneens van belang voor de uitkomsten van stressprocessen omdat deze bronnen hetzij direct, hetzij indirect via hun invloed op cognitieve appraisal, de keuze van copingstrategieën mede bepalen (Folkman, Schaeffer \& Lazarus, 1979; Lazarus \& Folkman, 1984). De hulpbronnen zouden geen directe invloed op de uitkomsten van stressprocessen hebben. Resultaten van onderzoeken naar utilitaire bronnen, persoonlijkheidskenmerken en sociale steun ( $2.3 .1 \mathrm{t} / \mathrm{m}$ 2.3.3) lijken Lazarus' visie in dit opzicht slechts gedeeltelijk te ondersteunen.

\subsubsection{Utilitaire bronnen}

Onder utilitaire bronnen wordt de sociale klasse (beroep en opleiding) en het inkomen verstaan. Een opmerkelijk consistent onderzoeksresultaat in met name epidemiologische studies betreft de samenhang tussen een lage sociale klasse en uiteenlopende lichamelijke en geestelijke gezondheidsstoornissen (Seidman \& Rapkin, 1983; Syme \& Berkman, 1976; Wills \& Langner, 1981).

Voor deze relatie zijn verschillende verklaringen naar voren gebracht: (a) Naarmate men over minder geld beschikt, vormen meer gebeurtenissen of situaties een probleem; (b) mensen die tot een lagere sociale klasse behoren, krijgen te maken met ingrijpender levensgebeurtenissen dan mensen in hogere sociale klassen; (c) in gezinnen met een lager inkomen zijn meer woordenwisselingen over financiële zaken, met alle gevolgen voor de stabiliteit van de partnerrelatie vandien, waaronder een afname van de steun van de partner; en (d) een lagere opleiding en een lagere sociaal-economische positie hangen samen met een geringere zelfwaardering, een geringer zelfvertrouwen en een lagere inschatting van de eigen competentie, hetgeen leidt tot een minder realistische stressperceptie, het gebruik van fatalistische en emotiereducerende copingstrategieèn en een afname van probleemoplossende strategieèn (Menaghan, 1983; Myers, Lindenthal \& Pepper, 1974; Schreurs et al., 1988; Wills \& Langner, 1981).

\subsubsection{Persoonlijkheidskenmerken}

Mensen die gekarakteriseerd worden door een zekere mate van sociale inadequatie, rigiditeil, verongelijktheid, zelfgenoegzaamheid of neuroticisme gebruiken meer intrapsychische en emotieregulerende copingstrategieèn, zoals wegvluchten in fantasieen, zichzelf verwijten maken, passiviteit, besluiteloosheid, vijandige reacties en zich terugtrekken, dan mensen die niet gekenmerkt worden door deze eigenschappen. Extraverte mensen gebruiken voomamelijk copingstrategieèn als rationele actie ondernemen, positief denken en humor (McCrae \& Costa, 1986; Schreurs et al., 1988; Van Heck \& Vingerhoets, 1989). 
De begrippen "self-esteem", "locus of control", "mastery", "hardiness", of, in het Nederlands, zelfwaardering, zelfrespect, zelfvertrouwen, beheersingsorièntatie en controle over het optreden of de uitkomsten van stressvolle gebeurtenissen zijn uit verschillende theorieèn afkomstig en hebben alle een iets andere betekenis (Bandura, 1986; Halfens, 1985; Rotter, 1975). Zij zijn samen te vatten als gegeneraliseerde, min of meer stabiele persoonlijkheidseigenschappen, die positieve oordelen over de eigenwaarde en de eigen vaardigheden en capaciteiten behelzen.

Uit de verschillende onderzoeksterreinen waamaar de genoemde concepten verwijzen, komt in het algemeen naar voren, dat mensen met een positieve mits realistische kijk op zichzelf: (a) zich met name in nieuwe en dubbelzinnige situaties minder angstig en bedreigd voelen (primaire appraisal); (b) valker het idee hebben dat zij iets kunnen doen om de situatie te veranderen (secundaire appraisal); (c) meer probleemgerichte copingstrategieën gebruiken; en (d) zich lichamelijk en geestelijk uiteindelijk beter voelen, dan mensen met weinig zelfvertrouwen en zelfrespect (Folkman, 1984; Folkman, Lazarus, Gruen \& DeLongis, 1986; Kobasa, 1979; Sanderman \& Ormel, 1992; Schaufeli \& Van Dierenđonck, 1992; Schreurs et al., 1988; Strickland, 1978; Van Heck \& Vingerhoets, 1989).

De situatie waarin en de wijze waarop persoonlijkheidskenmerken van invloed zijn op uitkomsten van stressprocessen, zoals welbevinden, zijn verre van duidelijk. Zo blijkt de specifieke stressvolle situatie in ogenschouw genomen te moeten worden: het welbevinden wordt bij financiële problemen en bij problemen in de werksituatie bijvoorbeeld meer beïnvloed door de persoonlijkheid dan door de gehanteerde copingstrategieën en in andere situaties, zoals bij huwelijks- en opvoedingsproblemen, juist meer door de copingstrategieën (Pearlin, Lieberman, Meneghan \& Mullan, 1981; Pearlin \& Schooler, 1982).

Er is eveneens meer onderzoek nodig om de juistheid van de opmerking van McCrae en Costa (1986) te kunnen nagaan. $\mathrm{Zij}$ suggereren dat de relatie tussen coping en welbevinden een schijnrelatie is die verklaard wordt door een gemeenschappelijke oorzaak, namelijk persoonlijkheidskenmerken. Dit is in tegenspraak met Lazarus' bewering dat coping de uitkomsten van stressprocessen direct beïnvloedt, terwijl hulpbronnen alleen een indirecte invloed op deze uitkomsten zouden hebben, namelijk via coping. Als de opmerking van McCrae en Costa juist zou zijn, zou coping niet werkelijk van invloed zijn op de mate waarin mensen zich weten aan te passen aan stresswolle omstandigheden en zou beïnvloeding van de persoonlijkheid meer effect sorteren dan het aanleren van effectieve copingsirategieěn.

\subsubsection{Saciale steun}

De sociale omgeving is van groot belang voor het welbevinden van mensen. Enerzijds kunnen sociale relaties cen bron van stress vormen (Suls, 1982). De "daily hassles", de alledaagse, chronische beslommeringen die vaak als stressvolle omstandigheden worden bestudeerd (Burks \& Martin, 1985; Kanner, Coyne, Schaeffer \& Lazarus, 1981; Vingerhoets, Jeninga \& Menges, 1989; Vingerhoets \& 
Menges, 1988), zijn bijwoorbeeld veelal inherent aan het functioneren in sociale rollen. De afwezigheid wan sociale relaties of het wegvallen ervan, zoals bij de dood van de partner of bij echtscheiding (Holmes \& Rahe, 1967), vormen eveneens een probleem op zich.

Anderzijds kunnen sociale relaties steun verschaffen. Sociale steun wordt gedefinieerd als: (a) communicaties, gedragingen en transacties tussen personen die van positief affect, waardering en geborgenheid getuigen en die de juistheid van persoonlijke waarden, overtuigingen en gevoelens bevestigen. Deze aspecten van sociale steun worden aangeduid als "emotionele sociale steun" en zijn de tegenpool van emotionele eenzaamheid (Peplau, 1985); (b) materièle en tastbare hulp, zoals geld, goederen, diensten en voorzieningen; en (c) informatie, adviezen, richtlijnen en feedback over het eigen functioneren, hetzij direct verstrekt, hetzij via sociale vergelijking overgebracht (Cobb, 1976, 1982; Wilcox \& Vemberg, 1985; Wortman \& Dunkel-Schetter, 1987).

Voor de meting van sociale steun worden structurele en functionele instrumenten gebruikt. Met structurele meetinstrumenten worden objectieve kenmerken van de sociale omgeving gemeten om een idee te krijgen van de sociale integratie en de inbedding van personen in sociale netwerken. Structurele indices voor sociale steun, zoals burgerlijke staat, het aantal en de aard van contacten met vrienden en professionele hulpverleners, het lidmaatschap van verenigingen of een geloofsgemeenschap, hangen positief samen met het wellbevinden (Turner, 1983).

Met functionele meetinstrumenten brengt men de persoonlijke interpretatie en waardering van sociale relaties in beeld. Tevredenheid binnen het huwelijk, tevredenheid met professionele hulpverleners, het gevoel er niet alleen voor te staan en dergelijke, lijken sterker met welbevinden samen te hangen dan structurele sociale ondersteuning (Schaeffer, Coyne \& Lazarus, 1981). De inbedding in een sociaal netwerk of de mate van sociale integratie is waarschijnlijk een noodzakelijke maar onvoldoende voorwaarde voor de ervaring door de omgeving gesteund te worden.

In onderzoeken worden vaak positieve correlaties tussen sociale steun en psychosomatisch welbevinden aangetroffen (Sarason \& Sarason, 1985). De verklaringen hiervoor lopen nogal uiteen. Eén verklaring is dat de correlaties kunstmatig zijn en moeten worden toegeschreven aan: (a) een inhoudelijke overlap tussen de meetinstrumenten voor sociale steun en welbevinden (Dohrenwend, Dohrenwend, Dodson \& Shrout, 1984); (b) een systematische onderschatting van de ontvangen sociale steun door mensen die zich geestelijk en/of lichamelijk niet goed voelen. Deze verklaring is met name van belang wanneer sociale steun met functionele instrumenten gemeten wordt (Wortman \& Dunkel-Schetter, 1987); of (c) een gemeenschappelijke derde variabele, bijwoorbeeld een geringe zelfwaardering, sociale incompetentie of een lage sociale klasse die zowel een geringe sociale ondersteuning als een laag welbevinden tot gevolg heeft (Jones, 1985; Peplau, 1985). 
Ook wanneer de aannemelijkheid van deze verklaringen door een juiste methodologie wordt gereduceerd, blijft het wooralsnog onduidelijk of een zekere mate van sociale steun preventief werkt en onwelbevinden voorkomt, de zogeheten sociale causatie-hypothese, of dat mensen die zich geestelijk en/of lichamelijk niet goed voelen, moeite hebben betekenisvolle rellaties aan te gaan en daarom sociaal geïsoleerd raken en weinig steun ontvangen, de zogeheten sociale selectie-hypothese (Tumer, 1983).

Onderzoekers die de rol van sociale steun in stressprocessen bestzderen, hanteren meestal impliciet de sociale causatie-hypothese. Zij zoeken antwoorden op de vragen hoe groot de invloed van sociale steun is op de uitkomsten van stressprocessen en vooral of deze invloed afhankelijk is van de ernst van de stressvolle omstandigheden. Ondanks de exponentiële groei van dit soort studies in de jaren tachtig is met name deze laatste vraag nog niet bevredigend beantwoord. Uiteenlopende theoretische invalshoeken leiden tot verschillende voorspellingen op dit terrein.

Het symbolisch interactionisme voorspelt voornamelijk hoofdeffecten van sociale steun: de positieve invloed van sociale steun op het welbevinden zou zich voor ieder in gelijke mate voordoen, ongeacht de emst van de stressvolle omstandigheden waarin men zich bevindt. Aangezien sociale relaties volgens deze visie in het algemeen een verhoogde zelfwaardering en gevoelens van veiligheid, eigenwaarde, competentie en controle tot gevolg hebben (Thoits, 1985), acht het symbolisch interactionisme sociale relaties van groot belang voor een ongestoorde persoonlijkheidsontwikkeling. In het verlengde daarvan dragen sociale relaties bij tot positieve uitkomsten in het geval er zich stressvolle situaties voordoen.

Onderzoeken waarin deze tussenliggende variabelen zijn opgenomen, zijn nauwelijks uitgevoerd, zodat als indirecte evidentie voor deze gedachtengang wordt gewezen op de hoofdeffecten die men aantreft wanneer structurele meetinstrumenten voor sociale steun gebruikt worden (Cohen \& Wills, 1985).

Uit Lazarus' stresstheorie worden voornamelijk buffer-effecten afgeleid: de positieve invloed van sociale steun op het welbevinden zou zich met name laten gelden wanneer men in stressvolle omstandigheden verkeert. $\mathrm{Na}$ het optreden van een potentieel stressvolle gebeurtenis zou het gevoel dat men door de sociale omgeving gewaardeerd en van informatie en daadwerkelijke hulp voorzien wordt, ertoe bijdragen dat men deze situatie als minder bedreigend ervaart (primaire appraisal). Als de situatie toch als stressvol wordt ervaren, zou sociale steun ertoe bijdragen dat deze met meer vertrouwen of met meer adequate copingstrategieën wordt tegemoet getreden (secundaire appraisal en coping).

Voor de beschermende invloed van sociale steun zijn eveneens voornamelijk indirecte aanwijzingen voorhanden: functionele metingen van globale emotionele steun en van sociale steun die uit informatie bestaat, blijken in stressvolle omstandigheden meer samenhang met het welbevinden te vertonen dan in minder stressvolle omstandigheden (Cohen \& Wills, 1985). 
men effectiviteit hoeft echter niet samen te vallen met het daadwerkelijk gebruik van deze strategieèn. Bovendien treedt vaak een contaminatie op tussen het aantal en de enst van de problemen waarvoor men zich geplaatst ziet en de waargenomen effectiviteit van copingstrategieèn (Menaghan, 1983).

De effectiviteit van coping kan het best worden onderzocht door het daadwerkelijk gebruik van copingstrategieën te meten en dit samen met de oorspronkelijke stressvolle sibuatie te relateren aan de uitkomsten van het stressproces. Ook op basis van dit soort studies zijn in zijn algemeenheid nauwelijks uitspraken over de effectiviteit van coping te doen. Deze effectiviteit is onder meer afhankelijk van de specifieke stressvolle situatie. Afgezien van het feit dat niet alle copingstrategieën in alle situaties gebruikt kunnen worden, hebben strategieën die wel algemeen te hanteren zijn, in verschillende omstandigheden verschillende effecten. "Positieve vergelijkingen maken" heeft bijvoorbeeld bij echtelijke en opvoedingsproblemen meer effect op het geestelijk welbevinden dan bij financiële problemen en bij problemen in de werksituatie (Pearlin \& Schooler, 1982).

Bovendien hebben sommige copingstrategieèn wel een reductie in het geestelijk onwelbevinden tot gevolg maar geen afname in de oorspronkelijke problemen. Dit is bijvoorbeeld het geval wanneer de copingstrategie "optimistische vergelijkingen maken" gebruikt wordt bij opvoedingsproblemen, terwijl omgekeerd de copingstrategie "directe actie ondernemen" bij echtelijke problemen geen effect op het geestelijk welbevinden heeft maar wel een positief effect op het aantal en de ernst van deze problemen (Menaghan, 1983). Tenslotte is het tijdsperspectief van belang: copingstrategieën die op de korte termijn weinig effectief zijn, kunnen op de langere termijn wel effecten blijken te hebben, terwijl ook het omgekeerde het geval kan zijn (Lazarus \& Folkman, 1984).

Uitspraken over de effectiviteit van copingstrategieën worden verder bemoeilijkt door de relatief beperkte theoretische en in het verlengde daarvan statistische benadering door onderzoekers van de manieren waarop coping effect kan hebben op de uitkomsten van stressprocessen. Onderzoekers die zich voomamelijk baseren op Lazarus' theorievorming voorspellen dat coping vooral in stressvolle omstandigheden een beschermende invloed heeft. Zij zijn dan ook veelal op zoek naar evidentie voor deze zogeheten buffer-effecten.

In het meest onderzochte stress-buffer-model wordt coping opgevat als moderator, dat wil zeggen als een "variable that affects the direction and/or strength of the relation between an independent or predictor variable and a dependent or criterion variable" (Baron \& Kenny, 1986, p. 1174). Moderator-hypotheses specificeren de voorwaarden waaronder stressvolle omstandigheden tot negatieve uitkomsten leiden: wanneer coping als moderator wordt gedefinieerd, interacteert coping als een antecedente conditie met andere condities, bijvoorbeeld stressoren, om een bepaalde uilkomst tot stand te brengen, bijvoorbeeld psychosomatisch welbevinden (Folkman \& Lazarus, 1988). Moderator-modellen voorspellen dat het negatieve effect van stressoren op het psychosomatisch welbevinden tijdens stressvolle omstandigheden 
geringer is bij mensen die een bepaalde copingstrategie vaak gebruiken dan bij mensen die deze wijze van probleemhantering minder frequent gebruiken.

Bij de toetsing van moderator-effecten worden meestal regressie analyses gebruikt. Men is daarbij vooral geïnteresseerd in de invloed van de interactie tussen de predictor (de stressvolle situatie) en de moderator (coping) op de uitkomsten van het stressproces. Aangezien deze interactie zelden een statistisch significant niveau bereikt, wordt vaak geconcludeerd dat coping geen bescherming biedt wanneer mensen zich in stressvolle situaties bevinden (Vingerhoets \& Van Heck, 1990).

Wanneer in dit soort studies hoofdeffecten van coping op het welbevinden worden aangetroffen, worden deze zelden becommentarieerd. Dit in tegenstelling tot de hoofdeffecten van sociale steun, die vanuit verschillende theoretische invalshoeken te verklaren zijn (zie 2.3.3). Een hoofdeffect van coping is vanuit Lazarus' theorievorming echter nauwelijks te verwachten en dan nog alleen wanneer copingstijlen in plaats van "coping efforts" zijn onderzocht. Een positief hoofdeffect betekent namelijk dat mensen die een bepaalde copingstijl in het algemeen frequent gebruiken, zich ongeacht de emst van de stressvolle omstandigheden waarin zij zich bevinden, in sociaal, psychisch en/of somatisch opzicht beter voelen dan mensen die hun problemen in het algemeen niet op de betreffende wijze hanteren.

Eén verklaring voor het aantreffen van hoofdeffecten kan luiden dat een dergelijk effect achterliggende, zogeheten derde variabelen, verhult. Eerder is reeds opgemerkt dat persoonlijkheidskenmerken en mogelijkerwijs ook andere hulpbronnen een gemeenschappelijke oorzaak kunnen vormen van coping en van verschillende uitkomsten van stressprocessen. Hiermee zou een hoofdeffect van coping op deze uitkomsten als een schijneffect ontmaskerd zijn (zie 2.3.2).

Een andere verklaring is vanuit Lazarus' theorievorming wel te rechtvaardigen: coping kan een mediërende functie hebben. "In general, a given variable may be said to function as a mediator to the extent that it accounts for the relation between the predictor and the criterion" (Baron \& Kenny, 1986, p. 1176). Wanneer coping als mediator wordt opgevat, betekent dit dat de invloed van een antecedent, i.c. een stressvolle situatie, op bepaalde uitkornsten, bijvoorbeeld psychosomatisch welbevinden, niet rechtstreeks verloopt maar indirect via én of meerdere copingstrategieën.

Coping kan toch een beschermende werking hebben, namelijk wanneer zou blijken dat stressvolle omstandigheden een bepaalde copingstrategie zouden activeren of mobiliseren én wanneer deze strategie tot gevolg heeft dat men in zich in deze omstandigheden in sociaal, psychisch en/of somatisch opzicht toch prettig voelt. De negatieve invloed van stressvolle omstandigheden wordt dan tenietgedaan door de activering van effectieve copingstrategieën. 


\subsection{Besluit: De stresstheorie van R.S. Lazarus}

Er is opmerkelijk weinig inhoudelijke kritiek op Lazarus' theorievorming over emoties, stress en coping. Zijn visie op stressreacties als resultaat van interacties tussen mens en omgeving, de actieve rol die mensen kunnen spelen om te voorkomen dat stressvolle omstandigheden negatieve consequenties hebben en de nadruk op cognitieve factoren, coping en multicausaliteit in het ontstaan van stressreacties zijn gemeengoed geworden.

Door de grote hoeveelheid variabelen die Lazarus van belang acht en de vele unien bidirectionele relaties tussen deze variabelen, is de theorie in zijn geheel inhoudelijk weliswaar interessant, maar empirisch nauwelijks te onderzoeken. Men beperkt zich meestal tot het opstellen en toetsen van veronderstellingen die op afgebakende onderdelen van de theorie betrekking hebben.

Theoretische modellen waarin meér variabelen zijn opgenomen dan stressvolle omstandigheden, copingstrategieèn en uitkomsten van het stressproces, worden in de literatuur net zo weinig aangetroffen als analyse-modellen die Wheaton (1985) aanduidt als "resource mobilization theories of stress-buffering" (p. 356). Dit soort modellen zou meer inzicht kunnen bieden in de processen die ten grondslag liggen aan de invloed van potentieel stressvolle omstandigheden op de sociale, psychische en somatische gezondheid van mensen dan de huidige, minder complexe onderzoeksmodellen en daarmee meer recht doen aan Lazarus' fundamentele bijdrage aan de theorievorming over stress. Dat men ze in onderzoeksliteratuur relatief weinig aantreft, heeft wellicht als achtergrond dat deze modellen een zekere oorzakelijke of althans hiërarchische ordening tussen variabelen veronderstellen die men moeilijk te verdedigen en te analyseren acht. 


\section{Stressmodellen bij ouders van een verstandelijk gehandicapt kind}

De transactionele, cognitief-fenomenologische en procesmatige visie van R.S. Lazanus op stressprocessen heeft een belangrijke aanzet gegeven tot onderzoek naar verklaringen voor de verschillen in stress tussen ouders van een kind met een verstandelijke handicap. Evenals bij stressonderzoeken in het algemeen (zie 2.5) is in het merendeel van dit soort studies slechts een beperkt aantal variabelen en hun onderlinge relaties bestudeerd.

In $3.2 . t / \mathrm{m} 3.4$ worden daarom drie modellen opgesteld die weliswaar niet de pretentie hebben het gehele stressproces in deze gezinnen in kaart te brengen, maar wel meerdere, ons inziens belangrijke dimensies van dit probleemveld: het zogeheten basismodel, het copingmodel en het sociale-steunmodel. Bij de constructie van deze verklaringsmodellen is gebruik gemaakt van gegevens uit (onderzoeken naar) de stresstheorie van Lazanus in het algemeen en van bevindingen uit studies naar stress bij ouders van een (verstandelijk) gehandicapt of emstig ziek kind in het bijzonder. Voorafgaand aan de constructie van deze modellen wordt in 3.1 eerst nader ingegaan op het begrip "stress".

\subsection{Stress}

De term "stress" wordt in het onderhavige onderzoek gebruikt als aanduiding voor de respons van ouders op hun leven met een verstandelijk gehandicapt kind. Als synoniemen worden ook "belasting" en "druk" gebruikt. "Stress" verwijst met andere woorden naar de afhankelijke variabele in het onderzoek.

In verschillende studies wordt "stress" op uiteenlopende en soms tamelijk willekeurige manieren geconceptualiseerd en geoperationaliseerd: "some investigators may say that the parent of a disabled child is coping adequately if the child is getting to school regularly and behaving appropriately while in school, or if the parent is not depressed, or if the child's siblings are behaving appropriately. A wide variety of 
more or less appropriate ... outcomes (dependent variables) can be operationalized" (Friedrich, Wiltumer \& Cohen, 1985, pp. 130-131).

In de onderhavige studie wordt "stress" op twee manieren geconceptualiseerd, namelijk als (waargenomen) concrete problemen van ouders en als psychosomatisch onwelbevinden. Dit sluit ten eerste aan bij de verschillende soorten uitkomsten van stressprocessen die onderzoekers in de traditie van Lazarus in het algemeen als afhankelijke variabelen bestuderen (zie 2.4).

Ten tweede gebruiken vele onderzoekers op het gebied van stress bij ouders van een (verstandelijk) gehandicapt kind hetzij meetinstrumenten betreffende het psychisch welbevinden van ouders, hetzij speciaal geconstrueerde vragenlijsten die betrekking hebben op de mate waarin ouders verschillende aspecten van hun situatie als belastend beleven (zie bijwoorbeeld Bos, 1977; Friedrich, Greenberg \& Cmic, 1983; Holroyd, 1974; Janssen, 1982; McCubbin et al., 1982; Suurmeijer, 1980; Wels \& Robbroecks, 1991a, 1991b). Afhankelijk van hun doelstellingen hebben laatstgenoemde vragenlijsten betrekking op verschillende soorten problemen, zoals tijdsdruk, financiële problemen, beperkingen in de mogelijkheden van de ouders en de andere kinderen in het gezin, gezinsverstoring, schuld- en schaamtegevoelens, tobben over de ontwikkelingsmogelijkheden van het gehandicapte kind, acceptatie van de handicap, de situatie aankunnen of juist willen veranderen, echtelijke problemen en dergelijke. Hoewel soms de indruk wordt gewekt dat het bij de meting van deze problemen zou gaan om objectief vast te stellen druk, hebben deze vragenlijsten betrekking op cognitieve probleemtaxatie door de respondenten, i.c. de eigen interpretatie door de betreffende ouder van diverse aspecten van de gezinssituatie. Deze subjectieve operationalisatie van stress sluit tenslotte aan bij de kritische opmerking van Cox (1978) betreffende de normatieve gegevens in stimulusbenaderingen (zie ook 2.1): stress bestaat in eerste instantie in de ogen wan de persoon in kwestie en niet in de ogen van de onderzoeker.

De waargenomen concrete problemen van ouders en hun psychosomatisch onwelbevinden zijn de afhankelijke variabelen in alle drie de stressmodellen die in $3.2 \mathrm{t} / \mathrm{m}$ 3.4 ontwikkeld worden. Aangenomen wordt dat, wanneer ouders eén of meer problemen ervaren, dit op den duur kan leiden tot psychosomatische klachten: in de stressmodellen gaan de concrete problemen vooraf aan het psychosomatisch onwelbevinden van ouders.

\subsection{Het basismodel}

In het basismodel ten aanzien van stress bij ouders van een kind met een verstandelijke handicap zijn voomamelijk variabelen opgenomen waarvan uit onderzoeken naar de belasting van deze ouders blijkt dat deze gerelateerd zijn aan de druk die ouders ervaren. In concreto wordt in het basismodel verondersteld dat de concrete problemen van ouders en hun psychosomatisch onwelbevinden afhankelijk zijn van potentieel stressvolle kenmerken van het verstandelijk gehandicapte kind (3.2.1), 
kenmerken van de ouders (3.2.2) en kenmerken van de andere kinderen in het gezin (3.2.3).

\subsection{Kenmerken van het verstandelijk gehandicapte kind}

Kinderen met een verstandelijke handicap verschillen van elkaar op een aantal dimensies. Uit onderzoeken blijkt dat de belangrijkste potentieel stressvolle kenmerken van het verstandelijk gehandicapte kind zijn: het geslacht, het verstandelijk niveau van functioneren, de leeftijd, de lichamelijke gezondheid, de gedragsproblematiek, de sociale redzaamheid en de zelfredzaamheid.

\section{Geslacht}

Onderzoeksbevindingen met betrekking tot de relatie tussen stress bij ouders en het geslacht van het verstandelijk gehandicapte kind spreken elkaar tegen. Ouders van een verstandelijk gehandicapte zoon ervaren in het onderzoek van Gresnigt en Gresnigt-Strengers (1973) meer problemen dan ouders van een gehandicapte dochter. De auteurs schrijven dit toe aan de verschillende verwachtingen van ouders ten aanzien van kinderen in het algemeen: zonen moeten zelfstandig zijn en prestaties leveren terwijl dochters afhankelijker mogen zijn en vooral behulpzaam moeten zijn. Aangezien verstandelijk gehandicapte jongens moeilijker aan de betreffende rolverwachtingen kunnen voldoen dan verstandelijk gehandicapte meisjes, zou het voor ouders van een gehandicapte zoon moeilijker zijn de handicap te aanvaarden. In een onderzoek van Friedrich (1979) rapporteren moeders van een verstandelijk gehandicapte dochter daarentegen meer problemen dan moeders van een gehandicapte zoon. De auteur geeft geen verklaring voor dit verschil. Een aantal andere onderzoekers vindt tenslotte geen relaties tussen het geslacht van het verstandelijk gehandicapte kind en de problemen respectievelijk het emotioneel functioneren van ouders (Cummings, 1976; Cummings, Bayley \& Rie, 1966; Gath, 1977; Janssen, 1982).

\section{Verstandelijk niveau van functioneren}

Zwakzinnigheid wordt van oudsher in eerste instantie gedefinieerd aan de hand van beperkingen in de intellectuele vermogens. "Wij zouden zwakzinnigheid als volgt willen omschrijven: Een aangeboren of in de prille jeugd verworven beperktheid van de geestelijke functies en/of de verdere ontwikkelingsmogelijkheid daarvan. Hierbij is het verstandelijk tekort het meest opvallend, terwijl daamaast de sociale aanpassing bemoeilijkt of onmogelijk is" (Noorda, 1985, p. 16).

Er bestaan verschillende classificatiesystemen die verfijningen in de verstandelijke niveaus aanbrengen op basis van onderzoek ter bepaling van het intelligentiequotiènt, zoals het systeem van de American Association on Mental Deficiency (Grossman, 1973), het DSM-III-R systeem (Koster van Groos, 1989) en het ICIDH-systeem van de World Health Organization (WHO, 1980). Meestal worden vier niveaus van verstandelijk functioneren met een IQ lager dan ongeveer 70 onderscheiden. De terminologie behorend bij deze indelingen verandert voortdurend omdat sommige termen in de loop der jaren tot sociale diskwalificaties c.q. tot scheldwoorden 
verworden. Een vrij gebnuikelijke vierdeling is: zeer emstig of diep verstandelijk gehandicapt (idioot, "profoundly retarded") met een IQ lager dan 20 tot 25; ernstig verstandelijk gehandicapt (laag imbeciel, "severely retarded") met een IQ tussen 20 tot 25 en 35 tot 40; matig verstandelijk gehandicapt (hoog imbeciel, "moderately retarded") met een IQ tussen 35 tot 40 en 50 tot 55; en licht verstandelijk gehandicapt (laag debiel, "mildly retarded") met een IQ tussen 50 tot 55 en 70.

De samerihang tussen het verstandelijk niveau van functioneren van het gehandicapte kind en de stress van ouders is niet geheel duidelijk. Janssen (1982) neemt in zijn onderzoek alleen kinderen op met een IQ lager dan ongeveer 50 en treft geen lineaire verbanden aan met de mate waarin ouders hun situatie als moeilijk ervaren. Het onderzoek van Wishart, Bidder en Gray (1980) leidt tot de conclusie dat ouders van een licht verstandelijk gehandicapt kind in het algemeen minder stress ervaren dan ouders van een kind dat op een lager niveau functioneert. Blacher, Nihira en Meyers (1987) komen tot de bevinding dat de atmosfeer en het sociale klimaat in gezinnen met een ernistig verstandelijk gehandicapt kind wel slechter is dan in gezinnen met een minder emstig verstandelijk gehandicapt kind, maar de huwelijksrelatie, de dagelijkse gang van zaken zoals eten en slapen, en de mate waarin ouders aangeven te kunnen omgaan met de handicap van hun kind niet.

Het onderzoek van Gresnigt en Gresnigt-Strengers (1973) laat een nog meer gedifferentieerd beeld zien. Een emstig verstandelijk gehandicapt kind verstoort de activiteiten van de andere kinderen in het gezin, de vrijetijdsbesteding en de externe relaties van alle gezinsleden meer dan een zeer ernstig of matig verstandelijk gehandicapt kind. In gezinnen met een zeer emstig verstandelijk gehandicapt kind zijn de relaties tussen de ouders onderling en die tussen de ouders en hun andere kinderen, de alledlaagse activiteiten, de nachtrust en de vakanties in gelijke mate verstoord als in gezinnen met een ernstig verstandelijk gehandicapt kind, terwijl in gezinnen met een matig verstandelijk gehandicapt kind ook op deze punten minder verstoring geconstateerd wordt.

\section{Leeftijd}

Het uit de literatuur verkregen beeld met betrekking tot de relatie tussen de leeftijd van het verstandelijk gehandicapte kind en de stress van ouders is eveneens verwarrend. Er zijn studies waarin rechtlijnige verbanden worden aangetoond. De richting van deze relaties is echter niet altijd dezelfde. Soms blijkt dat vaders meer vreugde aan hun verstandelijk gehandicapte kind beleven, minder depressief zijn en minder stress ervaren naarmate dit kind ouder wordt. Voor moeders is deze relatie niet aangetroffen (Cummings, 1976; Cummings et al., 1966). Andere studies tonen daarentegen aan dat ouders hun situatie juist belastender vinden naarmate het gehandicapte kind ouder wordt en het, althans in deze studies, bij het opgroeien meer gedragsproblemen krijgt (Donovan; 1988; Gallagher, Beckman \& Cross, 1983; Janssen, 1982).

In weer andere studies worden geen lineaire verbanden aangetroffen (Beckman, 1983; Friedrich, 1979; Gresnigt \& Gresnigt-Strengers, 1973). Deze laatste bevinding 
kan verklaard worden door het feit dat het chronische onderliggende verdriet van ouders, de zogeheten "chronic sorrow" (Olhansky, 1969), periodiek naar boven komt en wel bij die ontwikkelingsfasen waarin het verschil tussen hoe het kind is en hoe het zou kunnen zijn als het geen achterstand zou hebben, pijnlijk duidelijk is. Markeringspunten voor deze fasen zijn de periode dat het kind normaliter zou moeten gaan leren lopen of praten, de leeftijd dat het kind voor het eerst naar school gaat, de leeftijd dat andere kinderen naar een middelbare school gaan en de periode dat de beslissing tot definitieve uithuisplaatsing genomen wordt. Er zijn aanwijzingen dat de stress van ouders tijdens deze periodes groter is dan tussen deze periodes (Wikler, 1986; Wikler, Wasow \& Hatfield, 1981).

\section{Lichamelijke gezondheid}

De lichamelijke gezondheidstoestand van verstandelijk gehandicapten kan gedefinieerd worden aan de hand van lichamellijke klachten, aandoeningen en handicaps en hiermee samenhangend het medicijngebruik, het bezoek aan artsen, periodes van ziekte en dergelijke. Verschillende onderzoekers komen tot de bevinding dat de stress van ouders groter is naarmate de lichamelijke gezondheid van het kind slechter is.

Een zwakke lichamelijke gezondheid van het kind is een extra bron van zorg voor ouders: zij maken zich ongerust over de huidige conditie van het kind en over de ontwikkeling van zijn of haar gezondheid in de toekomst (Friedrich et al., 1983). Bovendien kumnen gezondheidsstoomissen van het gehandicapte kind problemen voor de overige gezinsleden met zich brengen. De nachtrust van het gezin kan verstoord worden; normale gezinsactiviteiten, zoals een dagje weg gaan, kunnen moeilijker ondernomen worden; door de tijd en de energie die meestal de moeder besteedt aan de zorg voor het kind, kan zij minder aandacht besteden aan zich zelf, haar partner en de andere kinderen; de ouders en soms ook de andere kinderen kunnen moeilijker deelnemen aan sociale activiteiten; en de verzorging van een ziek kind kan een extra druk leggen op de gezinsfinanciën (Beckman, 1983; Bradshaw \& Lawton, 1978; Friedrich et al., 1985; Gresnigt \& Gresnigt-Strengers, 1973; Gallagher et al., 1983; Holroyd \& Guthrie, 1979).

\section{Gedragsproblemen}

Naarmate het gehandicapte kind meer gedragsproblemen heeft, ervaren ouders meer stress. Dit is een consistent onderzoeksresultaat, dat bovendien betrekking heeft op verschillende soorten gedragsproblemen, zoals agressief en destructief gedrag, autisme en automutilatie (Janssen, 1982), "internalizing (shy and timid daydreams) and extemalizing (lies, steals) behavior problems" (Friedrich et al., 1985, p. 133), "harming others, harming self, destroying property, interrupting sleep of others, irritating others, sexual aggressiveness, and "other" problem behavior" (Orr, Cameron \& Day, 1991, p. 446), een moeilijk temperament (Beckman, 1983) en onder- respectievelijk hyperactiviteit (Bradshaw \& Lawton, 1978).

Ouders van een autistisch verstandelijk gehandicapt kind blijken depressiever te zijn, meer teleurgesteld in het kind, meer bezorgd over de toekomst en blijken het kind 
alls storender voor het gezin te ervaren dan ouders van een verstandelijk gehandicapt kind dat niet autistisch is (Donovan, 1988; Holroyd \& McArthur, 1976). Men kan er echter over twisten of autisme, i.c. het onvermogen om tot een adequate synthese van informatie te komen, vooral als een gedragsprobleem gecategoriseerd moet worden of als een gebrek aan sociale vaardigheden. Autisten hebben namelijk vaak een ernstige taalachterstand, zijn achtergebleven in hun sociale ontwikkeling, maken soms bizarre en stereotype bewegingen, hebben vaak vreemde spelpatronen en kunnen schreeuw- en gilbuien krijgen als zij niet begrepen worden. Overigens zijn ook verschillende van deze aspecten wan autisme geassocieerd met problemen en gevoelens văn onwelbevinden van ouders (Beckman, 1983; Bradshaw \& Lawton, 1978: Gallagher et al., 1983).

\section{Sociale redzaamheid}

Sociale redzaamheid kan omschreven worden als de mate waarin mensen met een verstandelijke handicap kumnen voldoen aan de dagelijkse eisen van de maatschappij, i.c. het gezin waartoe zij behoren, de voorziening waarin zij verblijven of de samenleving in bredere zin (Kraijer, 1988). Aangezien deze eisen zeer divers zijn, is het begrip sociale redzaamheid in verschillende studies op witeenlopende manieren geoperationaliseerd. Een vast onderdeel ervan is de mate waarin en de wijze waarop het gehandicapte kind in contact treedt met mensen in zijn of haar omgeving, zoals zijn of haar sociale gerichtheid, sociale vaardigheden (delen, lenen, hulp aanbieden) en vermogens tot communicatie, al dan niet met gesproken taal. In de onderhavige studie wordt het begrip sociale redzaamheid beperkt tot dit soort mogelijkheden tot sociaal contact en valt de zelfredzaamheid van het kind, dikwijls een onderdeel van de operationalisatie van sociale redzaamheid (zie bijvoorbeeld Kraijer \& Kema, 1972; Van der Meulen \& Kema, 1976), buiten de definitie van deze term.

Uit verschillende studies blijkt dat de stress van ouders groter is naarmate het gehandicapte kind zijn of haar wensen minder goed tot witdrukking kan brengen en zijn of haar omgeving minder goed begrijpt, zoals bij autisten het geval is, het minder sociaal gericht is, minder hulp aanbiedt, slechter in staat is relaties aan te gaan en minder goed weet te reageren op sociale stimuli (Beckman, 1983; Gallagher et al., 1983; Janssen, 1982). Bradshaw \& Lawton (1978) vinden geen relatie tussen de mate waarin het kind kan spreken en gesproken taal kan begrijpen en gevoelens van onwelbevinden van moeders.

\section{Zelfredzaamheid}

Zelfredzaamheid duidt de mate aan waarin het verstandelijk gehandicapte kind zonder hulp van anderen kan eten, zich aan en uit kan kleden en voor zijn of haar persoonlijke hygiëne kan zorgen (zich wassen, naar toilet gaan, tanden poetsen en dergelijke). Items over de zelfredzaamheid van het kind worden vaak in éen schaal opgenomen met items betreffende de sociale redzaamheid (Janssen, 1982) of de lichamelijke beperkingen van het kind (Beckman, 1983; Friedrich et al., 1983). Hoewel scores op dit soort samengestelde schalen wel een samenhang vertonen met de stress van ouders, is niet duidelijk in hoeverre de zelfredzaamheid van het gehandicapte kind aan deze relatie bijdraagt, omdat deze items niet afzonderlijk 
worden geanalyseerd. Bradshaw en Lawton (1978) hebben de zelfredzaamheid van het kind wel apart gemeten en geanalyseerd; zij vinden geen relatie met het welbevinden van moeders.

\section{Besluit: Potentieel stressvolle kenmerken wan het verstandelijk gehandicapte kind}

Ouders van een verstandelijk gehandicapt kind bevinden zich in verschillende omstandigheden, afhankelijk van de specifieke kenmerken van het gehandicapte kind. Van een aantal van deze kenmerken zijn de relaties met de stress van ouders niet eenduidig, zoals het geslacht, het verstandelijk niveau van functioneren, de chronologische leeftijd van het kind en een beperkte zelfredzaamheid. Andere kenmerken lijken duidelijker met de stress van ouders samen te hangen, zoals een zwakke lichamelijke gezondheid, een grote mate van gedragsproblematiek en een geringe sociale redzaamheid. Waarschijnlijk hangen sommige kenmerken niet alleen met de stress van ouders, maar ook met elkaar samen: aangezien onderzoekers mogelijke intercorrelaties, voor zover na te gaan, niet bestuderen, is onbekend welke kenmerken van het kind van doorslaggevend belang zijn bij de verschillende concrete problemen van ouders en/of hun psychosomatisch onwelbevinden.

\subsubsection{Kenmerken van de ouders}

In de beschrijving van de stresstheorie van R.S. Lazarus zijn drie hulpbronnen genoemd die in het algemeen een rol spelen bij de uitkomsten van stressprocessen: utilitaire bronnen, persoonlijkheidskenmerken en sociale steun (zie 2.3.1 t/m 2.3.3). Aangezien een apart sociale-steunmodel wordt opgesteld ten aanzien van stress bij ouders van een kind met een verstandelijke handicap (zie 3.4), worden hier alleen de twee andere hulpbronnen behandeld. Hieraan voorafgaand wordt nagegaan in hoeverre de leeftijd van ouders gerelateerd is aan de stress die zij ervaren.

\section{Leeftijd van de ouders}

In het algemeen lijkt de leeftijd van ouders geen samenhang te vertonen met de problemen die zij ervaren of hun psychosomatisch welbevinden (Bradshaw \& Lawton, 1978; Byme \& Cunningham, 1985; Gresnigt \& Gresnigt-Strengers, 1973). Wel wordt gesuggereerd dat naarmate ouders bij de geboorte van het gehandicapte kind ouder zijn, zij zich meer zorgen maken over de toekomst van dit kind. Dit wordt toegeschreven aan het feilt dat oudere ouders het moment dat zij niet meer zelf voor het kind kunnen zorgen, eerder bereiken dan ouders die bij de geboorte van dit kind jonger zijn (Meadow \& Meadow, 1971).

\section{Utilitaire bronnen}

Een gebrek aan utilitaire bronnen gaat in het algemeen samen met een grote mate van stress (zie 2.3.1). Onderzoeken onder ouders van een kind met een verstandelijke handicap laten eveneens bij herhaling zien dat ouders die tot een lage sociale klasse gerekend worden en ouders met een laag opleidings- of beroepsniveau hun situatie als moeilijker ervaren, het verstandelijk gehandicapte kind storender voor het gezin achten, minder tevreden over hun huwelijk zijn en zich lichamelijk en geestelijk slechter voelen dan ouders met meer utilitaire bronnen (Donovan, 1988; 
Gallagher et all, 1983; Gresnigt \& Gresnigt-Strengers, 1973; Janssen, 1982). In twee onderzoeken van Friedrich hangt het aantal en de emst van de problemen van ouders echter niet samen met hun beroeps- en opleidingsniveau (Friedrich, 1979; Friedrich et al., 1985). Aangezien de geciteerde onderzoekers eventuele relaties tussen utilitaire bronnen en andere mogelijke determinanten van de stress van ouders niet nader bestuderen, is er geen duidelijkheid over de wijze(n) waarop of de reden(en) waarom deze hulpbronnen geassocieerd zijn met de stress van ouders.

\section{Persoonlijkheidskenmerken}

In thet algemeen gaan persoonlijkheidskenmerken alls neurotische labiliteit, een gebrek aan zelfrespect en een externe beheersingsoriëntatie samen met een hoge mate van stress (zie 2.3.2). Het leven van ouders van een kind met een verstandelijke handicap kan bestaan wit een aaneenschakeling van grotere en kleinere moeilijkheden, waarvoor vaak geen pasklare oplossingen voorhanden zijn. Uit onderzoeken blijkt dan ook dikwijls dat de gegeneraliseerde, min of meer stabiele persoonlijkheidseigenschappen waarop ouders in voorkomende problematische situaties terugvallen, van belang zijn voor de mate waarin zij hun leven als belastend ervaren.

Neurotische, depressieve en labiele ouders, ouders met een negatief zelfbeeld en weinig zelfwaardering ervaren meer problemen en voelen zich geestelijk slechter dan ouders met meer positieve persoonlijkheidskenmerken (Friedrich, 1979; Friedrich et al., 1983; Gallagher et al., 1983; Janssen, 1982). De mate waarin ouders het optreden van gebeurtenissen toeschrijven aan het eigen handelen (inteme locus of control) of aan krachten die zij niet onder controle hebben, zoals toeval, geluk of machtige anderen (externe locus of control; Rotter, 1975), lijkt in theorie eveneens van belang te zijn voor de stress die zij ervaren. In het enige ons bekende onderzoek waarin deze variabele is opgenomen, gaat een inteme locus of control wel samen met een geringer aantal problemen, maar bereikt deze samenhang geen statistisch significant niveau (Friedrich et al., 1985). Uit de onderzoeken waarin persoonlijkheidskenmerken van ouders zijn opgenomen, wordt overigens niet duidelijk op welke directe of indirecte manier(en) de persoonlijkheid van ouders een rol speelt bij de stress die zij ervaren.

\subsubsection{Kenmerken wan de andere kinderen}

Een kind met een verstandelijke handicap beïnvloedt miet alleen het leven van zijn of haar ouders, maar ook dat van de andere, doorgaans niet gehandicapte kinderen in het gezin. Uit onderzoeken blijkt dat opgroeien met een (verstandelijk) gehandicapte broer of zus zowel positieve als negatieve aspecten kan hebben. Positief is voornamelijk de ontwikkeling van een grote mate van altruissme en tolerantie jegens anderen. Negatieve gevolgen worden vooral geconstateerd bij de oudere zus van het gehandicapte kind, vooral wanneer zij het enige andere kind in het gezin is. Deze negatieve invloed kan bestaan uit: (a) jaloezie vanwege de tijd en aandacht die het gehandicapte kind van de ouders krijgt; (b) een te grote verantwoordelijkheid op jonge leeftijd, hetzij voor het gehandicapte kind hetzij voor huishoudelijke werkzaamheden; (c) emotionele problemen, angst en onzekerheid vanwege een te grote 
betrokkenheid bij het gehandicapte kind; (d) problemen in de socialle contacten met leeftijdgenoten, als gevolg van schaamtegevoelens of pesterijen; (e) concentratieverlies en verminderde prestaties op school; en (f) gedragsproblemen, thuis of op school (Byme \& Cunningham, 1985; Lonsdale, 1978; McAndrew, 1976; Tew \& Laurence, 1973; Walker, Thomas \& Russell, 1971).

Het onderhavige onderzoek heeft niet direct betrekking op de invloed van een gehandicapt kind op zijn of haar broer(s) en/of zus(sen), maar op de mogelijke rol die enkele kenmerken van deze andere kinderen spelen in het ontstaan of voortbestaan van de stress van ouders. Behandeld worden: de leeftijd van de andere kinderen, de gezinsgrootte, de plaats van het gehandicapte kind in de kinderrij en de kwaliteit van de relaties tussen het gehandicapte kind en zijn of haar broer(s) en/of zus(sen).

\section{Leeftijd van de andere kinderen}

Uit het onderzoek van Gresnigt en Gresnigt-Strengers (1973) blijkt dat ouders meer gezinsverstoring ervaren naarmate hun andere kinderen jonger zijn. Ter verklaring van dit overigens vaker aangetroffen lineaire verband wijzen Gallagher et al. (1983) op het feit dat jongere kinderen meer ouderlijke zorg en aandacht behoeven, hetgeen een extra druk op ouders legt. Bovendien gaan de andere kinderen in het gezin vaak een bron van emotionele of daadwerkelijke steun voor ouders vormen wanneer zij ouder worden.

\section{Gezinsgrootte (aantal broer(s) en/of zus(sen))}

Gegevens over de samenhang tussen de grootte van het gezin, i.c. het totaal aantal kinderen in het gezin, en de stress van ouders laten geen duidelijke conclusies toe. Byme en Cunningham (1985) concluderen in hun literatuuroverzicht dat er geen relatie bestaat tussen de gezinsgrootte en de stress van ouders. Sommige studies laten echter zien dat ouders die alleen een verstandelijk gehandicapt kind hebben, minder gezinsverstoring ervaren en zich prettiger voelen dan ouders die naast dit kind eén of meer andere kinderen hebben, terwijl ouders die naast het gehandicapte kind slechts eén ander kind hebben, meer stress ervaren dan ouders zonder andere kinderen én meer dan ouders met minstens twee andere kinderen (Bradshaw \& Lawton, 1978; Gresnigt \& Gresnigt-Strengers, 1973; Korn, Chess \& Fernandex, 1978).

\section{Plaats van het verstandelijk gehandicapte kind in de kinderrij}

Hoewel het onderzoek van Gresnigt en Gresnigt-Strengers (1973) laat zien dat de gezinsverstoring van ouders geen samenhang vertoont met de vraag of het verstandelijk gehandicapte kind het oudste, het middelste of het jongste kind in het gezin is, wordt veelal aangenomen en door onderzoek bevestigd dat de stress van ouders het grootst is wanneer het gehandicapte kind het oudste kind in het gezin is (Korn et al., 1978; Meadow \& Meadow, 1971). Ter verklaring hiervoor wijzen genoemde auteurs erop dat de verwachtingen van ouders bij de geboorte van hun eerste kind hoog zijn en hun teleurstelling des te groter, wanneer het gehandicapt blijkt te zijn. Bovendien zouden ouders zich schuldiger voelen en zich meer ongerust maken over mogelijke 
erfelijke factoren wanneer hun eerste kind gehandicapt is dan wanneer er al én of meer normaal begaafde kinderen zijn geboren.

\section{Relatie van het verstandelijk gehandicapte kind met broer(s) en/of zus(sen)}

Voor zover is na te gaan, is er geen onderzoek gedaan betreffende de samenhang tussen de kwaliteit van de relaties van het gehandicapte kind met zijn of haar broer(s) en/of zus(sen) en de stress van ouders. Toch mag worden aangenomen dat ouders slechtere relaties, met veel ruzies en conflicten, als een extra bron van spanning ervaren. Opmerkelijk is overigens dat zowel de ouders als de broer(s) en/of zus(sen) zelf de relaties met het gehandicapte kind vaak kwalitatief beter vinden dan die tussen deze broer(s) en/of zus(sen) onderling. Als mogelijke verklaring hiervoor wijst McAndrew (1976) op de gevoeligheid van ouders in dezen: "The relationship between the [mentally retarded] child and the siblings and the effect of het former on the latter seem to be very sensitive areas to many parents" (McAndrew, 1976, p. 228). Deze gevoeligheid kan ertoe bijdragen dat ouders hun andere kinderen impliciet of expliciet verbieden zich negatief uit te laten jegens of over hun gehandicapte broer of zus (zie ook: Byrne \& Cunningham, 1985; Cmic, Friedrich \& Greenberg, 1983).

\subsubsection{Besluit: Het basismodel}

Het basismodel ter verklaring van de stress van ouders van een kind met een verstandelijke handicap is in schema 3.1 gevisualiseerd. Dit exploratieve model veronderstelt, dat:

(a) de concrete problemen van ouders direct afhankelijk zijn van kenmerken van het verstandelijk gehandicapte kind, kenmerken van de ouders en kenmerken van de andere kinderen in het gezin (pijlen $\mathrm{a}, \mathrm{b}$ en c); en

(b) het psychosomatisch onwelbevinden van ouders direct afhankelijk is van hun concrete problemen (pijl d), direct afhankelijk is van kenmerken van het verstandelijk gehandicapte kind, kenmerken van de ouders en kenmerken van de andere kinderen (pijlen e, $\mathrm{f}$ en $\mathrm{g}$ ) en indirect van deze kenmerken afhankelijk is via de invloed van deze kenmerken op hun concrete problemen (pijlen $a^{*} d, b^{*} d$ en $c^{*} d$ ).

Eventuele relaties tussen de kenmerken van het verstandelijk gehandicapte kind, de ouders en de andere kinderen in het gezin worden vanwege de aard van deze kenmerken niet als hierarchisch geordend beschouwd; deze kenmerken worden als exogene variabelen opgevat (Pedhazur, 1982).

\subsection{Het copingmodel}

In het tweede model is coping opgenomen naast de variabelen uit het basismodel. Coping wordt gedefinieerd als de gedragsmatige en cognitieve manieren waarop ouders omgaan met de problemen waarvoor het leven met een verstandelijk gehandicapt kind hen stelt en met de emoties die met deze problemen gepaard gaan (zie ook 2.2). 


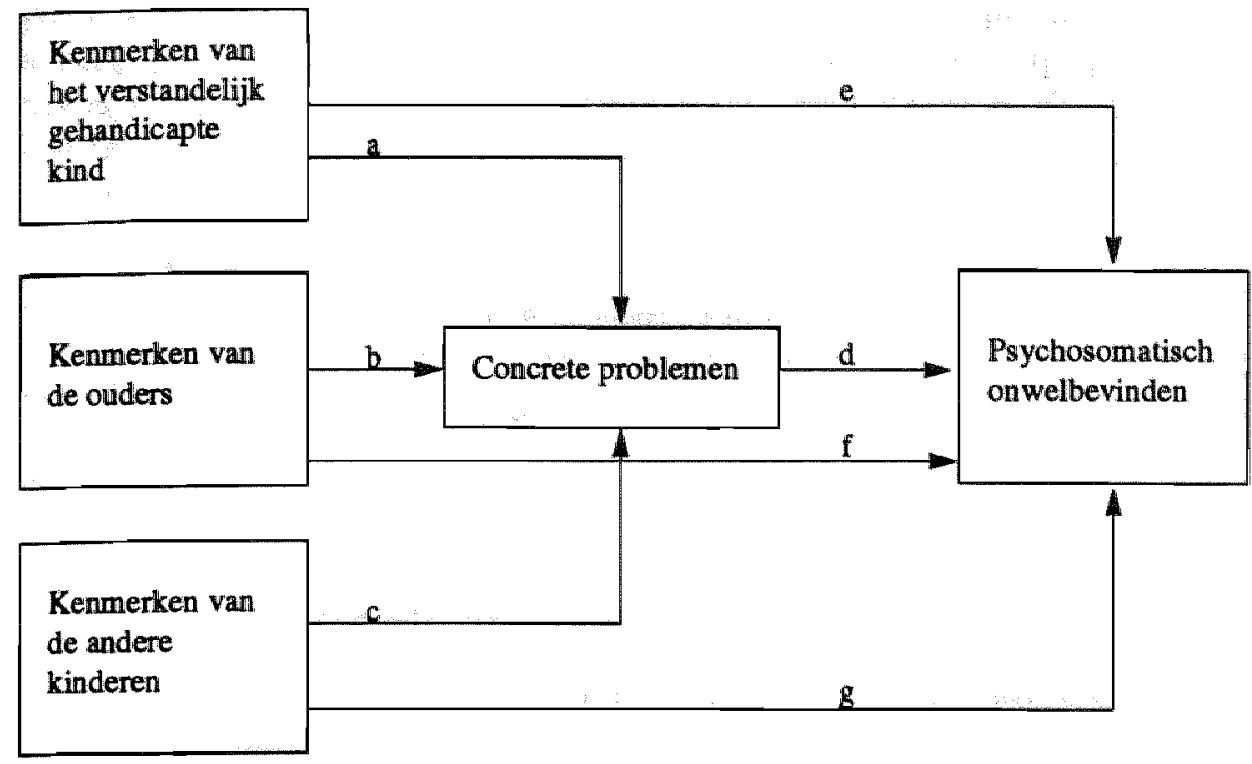

Schema 3.1. Basismodel ten aanzien van stress bij ouders van een kind met een verstandelijke handicap: theoretisch model

In het copingmodel wordt verondersteld wordt dat kennis over de manieren waarop ouders hun problemen en emoties hanteren, een meerwaarde heeft ten aanzien van de verklaring van hun psychosomatisch onwelbevinden boven de kennis die uit het basismodell naar voren komt.

Er is in het stressonderzoek in het algemeen weinig eenstemmigheid over de conceptualisering en de operationalisatie van coping (zie 2.2). Dit geldt ook voor studies naar stress biji ouders van een (verstandelijk) gehandicapt of ernstig ziek kind. Coping wordt vaak impliciet aanwezig verondersteld, maar zelden expliciet gemeten. De scores op de veel gebruikte Questionnaire on Resources and Stress (Holroyd, 1974) en de verkorte versie daarvan worden bijvoorbeeld niet alleen opgevat als indicatie voor (diverse aspecten van) de stress van ouders, maar tevens als indicatie voor copingvaardigheden en de effectiviteit van coping (Friedrich, 1979; Friedrich et al., 1983; Friedrich et al., 1985).

Bovendien zijn uiteenlopende cognitieve en gedragsmatige activiteiten als copingstrategieën opgevat, zoals een realistisch begrip van de conditie en de prognose van het kind en de consequenties ervan, aanvaarding van de handicap en afstemming van de verwachtingen op deze handicap, het actief zoeken en gebruiken van informatie en professionele en informele steun, handhaving van de gezinsintegratie, het zich terugtrekken binnen het gezin en het zich afschermen van de buitenwereld, een open communicatie en samenwerking binnen het gezin, een optimistische definitie van de situatie, overbescherming of verwerping van het gehandicapte kind, verwerving van therapeutische competentie en handhaving van de emotionele stabiliteit (Choi, Josten 
\& Christensen, 1983; Fotheringham \& Creal, 1974; Marcus, 1977; McCubbin, 1979; McCubbin et al., 1983; Shapiro, 1983). Tenslotte is zelden systematisch nagegaan in welke mate en op welke manier(en) copingstrategieèn een rol spelen in het proces dat bij ouders van een verstandelijk gehandicapt kind tot psychosomatisch onwelbevinden leidt.

Een van de weinige uitzonderingen op dit laatste punt vormt het onderzoek van Last (1986) onder ouders van een kind met kanker. Coping is in deze studie gemeten met de Utrechtse Coping Lijst (UCL; Schreurs, Van de Willige, Tellegen \& Brosschot, 1988; zie ook 2.2). Op grond van zijn bevindingen concludeert Last dat: (a) het patroon van copingstrategieèn bij de onderzochte ouders anders is dan bij een normgroep wan overigens niet nader beschreven respondenten: de ouders van cen kind met kanker hanteren de copingstijlen depressief reactiepatroon, sociale steun zoeken, palliatieve reacties, geruststellende gedachten en vermijding vaker dan de normgroep; (b) binnen de groep van ouders van een kind met kanker, ouders die gekenmerkt wordt door een neurotische of labiele persoonlijkheid, vaker een depressieve copingstijl gebruiken en vaker hun emoties en kwaadheid uiten dan ouders met minder neurotische of meer stabiele persoonlijkheidskenmerken; en (c) de copingstijlen depressief reactiepatroon, sociale steun zoeken en expressie van emoties of kwaadheid lineair geassocieerd zijn met een negatieve beleving van de situatie, terwijl de copingstijlen palliatieve reacties en geruststellende gedachten lineair samenhangen met een positieve beleving van de situatie. Last heeft in deze studie overigens niet gerapporteerd over de mogelijk beschermende, bufferende werking van copingstrategieèn.

In schema 3.2 is coping opgenomen in het basismodel ten aanzien van stress bij ouders van een kind met een verstandelijke handicap. Ter bevordering van de overzichtelijkheid zijn in dit schema de relaties tussen de variabelen uit het basismodel (zie schema 3.1) met een hoofdletter aangeduid. Pijl A verwijst naar de relaties tussen de kenmerken van het verstandelijk gehandicapte kind, de kenmerken van de ouders respectievelijk de kenmerken van de andere kinderen en de concrete problemen wan ouders (vergelijk de pijlen a $t / \mathrm{m} \mathrm{c}$ in schema 3.1). Pijl $\mathrm{B}$ verwijst naar de relaties tussen de exogene variabelen en het psychosomatisch onwelbevinden van ouders (vergelijk de pijlen e $t / \mathrm{m} \mathrm{g}$ in schema 3.1). Pijl $\mathrm{C}$ verwijst tenslotte naar de relatie tussen de concrete problemen van ouders en hun psychosomatisch onwelbevinden (vergelijk pijl $d$ in schema 3.1 ).

In het exploratieve copingmodel van schema 3.2 zijn meerdere manieren aangeduid waarop coping een rol kan spelen in het proces dat uiteindelijk leidt tot psychosomatisch onwelbevinden bij ouders van een kind met een verstandelijke handicap:

(a) coping wordt in eerste instantie opgevat als een reactie op de concrete problemen van ouders (pijl a);

(b) coping kan ook rechtstreeks gedetermineerd worden door kenmerken van het verstandelijk gehandicapte kind, kenmerken van de ouders en kenmerken van de andere kinderen in het gezin (pijlen b $t / \mathrm{m} \mathrm{d}$ ); 
(c) coping kan een beschermende werking hebben ten aanzien van het psychosomatisch onwelbevinden, hetzij als moderator (pijl f) hetzij als mediator (pijlen a*e, $b^{*} e, c^{*}$ e en $d^{*} e$ ); en

(d) coping kan onafhankelijk van de overige variabelen in het model een positieve of negatieve invloed op het psychosomatisch welbevinden van ouders uitoefenen (pijl e).

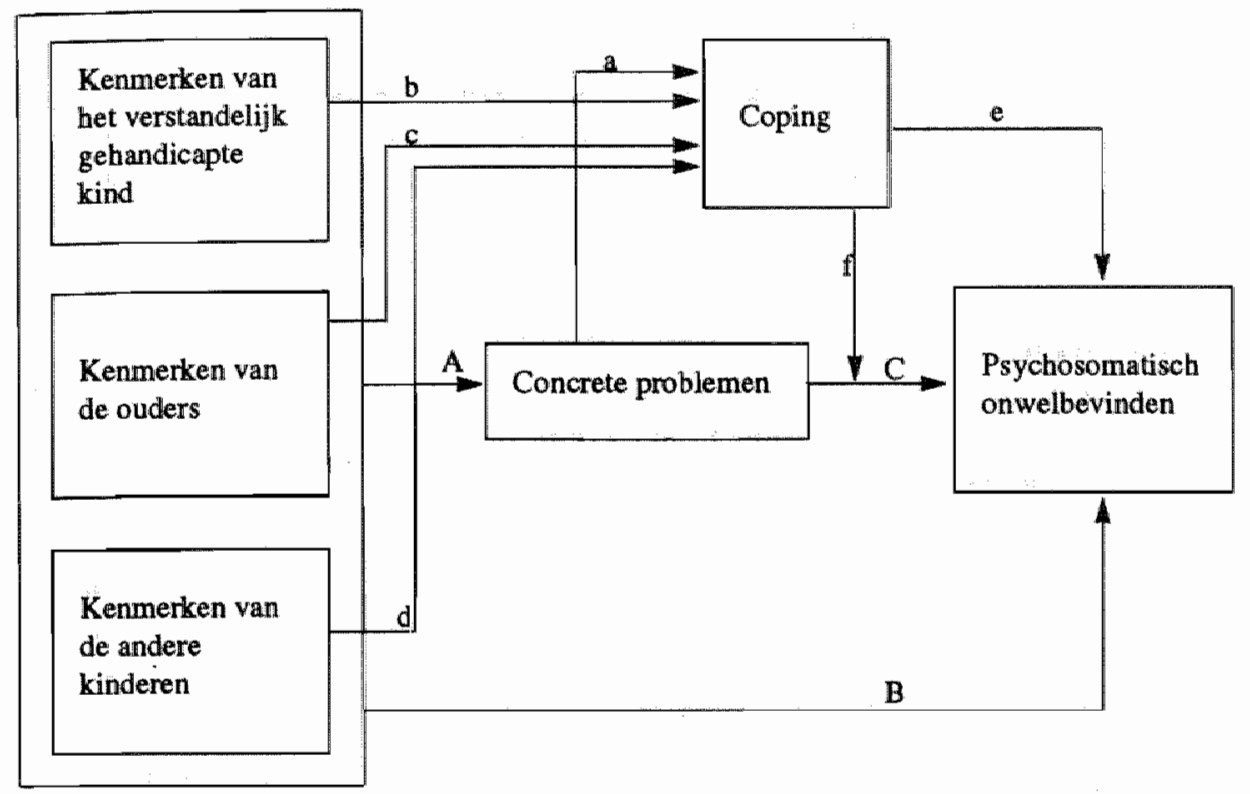

Schema 3.2. Copingmodel ten aanzien van stress bij ouders van een kind met een verstandelijke handicap: theoretisch model

\subsection{Het sociale-steunmodel}

In het derde model wordt sociale steun opgenomen naast de variabelen uit het basismodel. Sociale steun wordt gedefinieerd als de mate waarin ouders zijn geïntegreerd in een sociaal netwerk, de zogeheten structurele sociale steun, en als de persoonlijke interpretatie van sociale relaties en van de mate waarin ouders deze relaties als ondersteunend ervaren, de functionele sociale steun (zie ook 2.3.3). Verondersteld wordt dat kennis over diverse aspecten van de steun die ouders uit hun omgeving ontvangen, een extra bijdrage levert aan het inzicht in de verschillen in het psychosomatisch welbevinden tussen ouders van een kind met een verstandelijke handicap.

Uit onderzoeken op diverse terreinen komt naar voren dat structurele sociale steun in het algemeen positief gerelateerd is aan het welbevinden van alle respondenten, terwijl functionele sociale steun met name positief geassocieerd is met het welbe- 
vinden van die mensen die zich in de meest stressvolle omstandigheden bevinden. Niet geheel duidelijk is de wijze waarop deze relaties tot stand komen (zie 2.3.3).

In literatuur over stress bij ouders van een (verstandelijk) gehandicapt of emstig ziek kind wordt de positieve werking van sociale ondersteuning vaak benadrukt. Hoewel in de betreffende onderzoeken zelden een expliciet onderscheid gemaakt wordt tussen de twee soorten sociale steun, lijkt er meer evidentie te zijn voor de positieve werking van functionele steun dan voor de gunstige effecten van structurele sociale steun.

Van de vaak gebruikte structurele indices van sociale steun lijkt met name de burgerlijke staat van ouders een rol te spelen: alleenstaande ouders ervaren meer financiële problemen en meer beperkingen in hun mogelijkheden en voelen zich geestelijk slechter dan gehuwde of samenwonende ouders (Beckman, 1983; Byme \& Cunningham, 1985; Gallagher et al., 1983; Holroyd, 1974). Bradshaw en Lawton (1978) vinden overigens geen verschil in stress tussen gehuwde en alleenstaande moeders. Voorts wordt aangenomen dat ouders in hun religieuze overtuiging steun vinden voor de acceptatie van de handicap van hun kind, hetgeen zou bijdragen aan een relatief geringe belasting (Crnic et al., 1983). Structurele indices voor godsdienstige of levensbeschouwelijke overtuigingen, zoals het lidmaatschap van een (specifieke) geloofsgemeenschap of levensbeschouwelijke groepering, zijn echter niet altijd gerelateerd aan de stress van ouders. Sommige onderzoekers concluderen op basis van hun bevindingen dat roomskatholieke ouders minder stress ervaren dan protestantse of joodse ouders (Korn et al., 1978; Meadow \& Meadow, 1971), lerwijl Friedrich (1979) geen verschil aantreft tussen roomskatholieke en protestantse ouders in de ernst en het aantal van hun concrete problemen. Ook Byme en Cunningham (1985) concluderen in hun overzichtsartikel dat er te weinig aanwijzingen zijn om te kunnen spreken van relaties tussen stress en structurele indices voor geloofsovertuigingen. Zij suggereren dat functionele indices, zoals vragen naar de waargenomen steun uit religieuze of levensbeschouwelijke opvattingen, wel zouden samenhangen met stress.

In tegenstelling tot hetgeen bij stressonderzoeken in het algemeen wordt aangetroffen, tonen studies onder ouders van een (verstandelijk) gehandicapt kind vaak lineaire relaties aan tussen functionele indices van sociale steun en stress. Ouders ervaren minder problemen en voelen zich geestelijk beter naarmate zij: (a) meer tevreden zijn met hun huwelijk, minder spanningen binnen hun huwelijk hebben, beter communiceren met hun partner en meer de ervaring hebben dat hun partner hen daadwerkelijk steunt; (b) het sociale klimaat binnen het gezin als minder conflictueus en meer cohesief beschrijven; (c) meer de ervaring hebben door mensen uit hun sociale omgeving ondersteund te worden, zoals familie, vrienden, buren of andere ouders; en (d) meer tevreden zijn over de professionele hulpverlening (Bradshaw \& Lawton, 1978; Byrne \& Cunningham, 1985; Friedrich, 1979; Friedrich et al., 1985; Gallagher et al., 1983; Janssen, 1982). 
Studies waarin is onderzocht of sociale steun ouders als het ware beschermt wanneer zij zich in meer stressvolle omstandigheden bevinden, zijn ons niet bekend. Evenmin zijn ons onderzoeken bekend waarin de vraag centraal staat welke ouders zich meer en welke ouders zich minder door hun sociale omgeving ondersteund weten of voelen. Er bestaat dan ook weinig duidelijkheid over de manier(en) waarop de positieve invloed van sociale steun op de stress van deze ouders tot stand komt.

Om te kunnen nagaan in welke mate en op welke manier(en) steun vanuit de sociale omgeving verkregen wordt en vervolgens gerelateerd is aan het psychosomatisch welbevinden van ouders van een kind met een verstandelijke handicap, is het sociale-steunmodel opgesteld. De relaties die reeds in het basismodel zijn opgenomen (zie schema 3.1), zijn in het model in schema 3.3 met de hoofdletters A t/m C aangeduid (zie ook het copingmodel in schema 3.2).

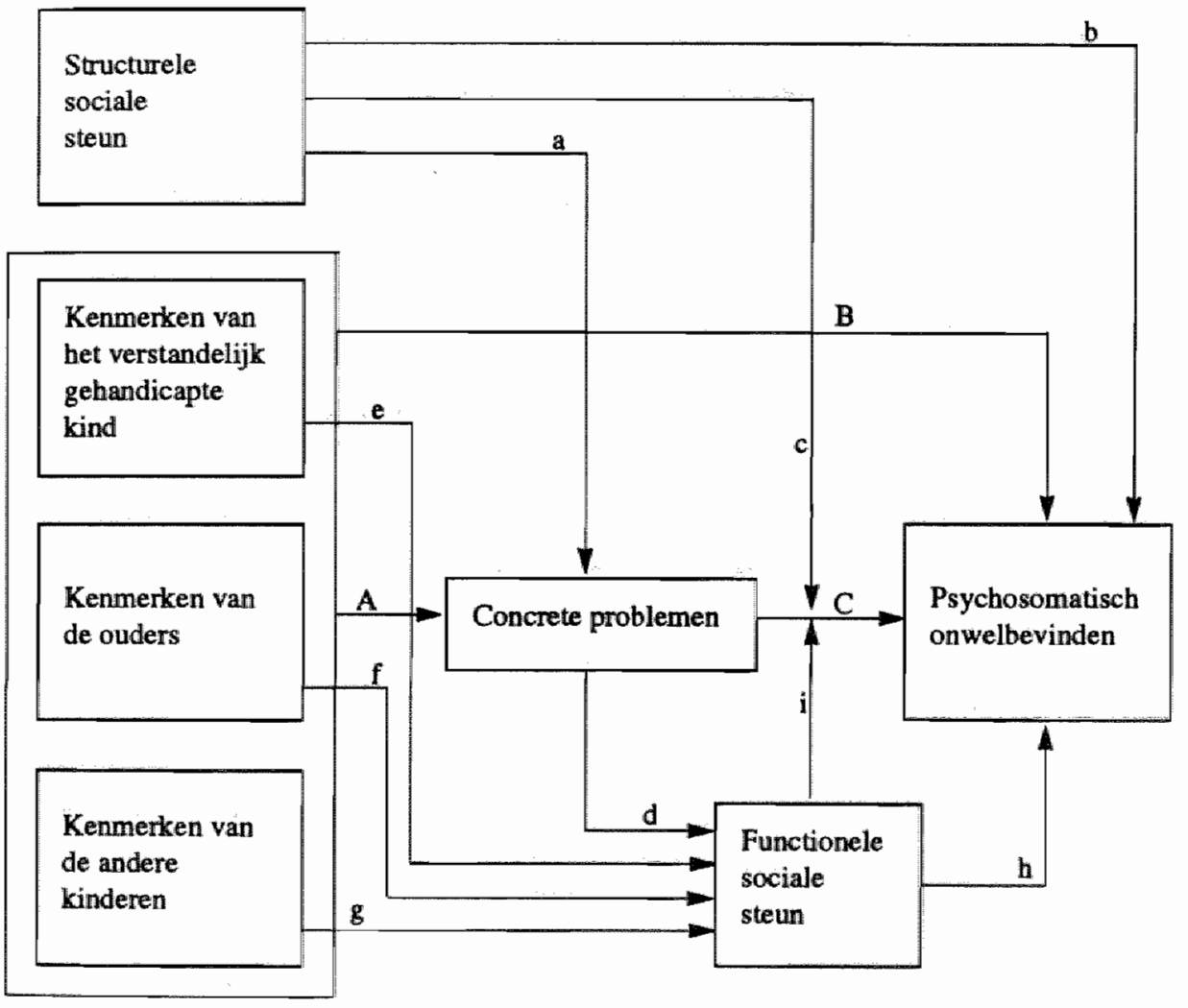

Schema 3.3. Sociale-steunmodel ten aanzien van stress bij ouders van een kind met een verstandelijke handicap: theoretisch model

In het exploratieve sociale-steunmodel in schema 3.3 wordt een onderscheid aangebracht tussen structurele en functionele sociale steun. Verondersteld wordt dat 
structurele sociale steur op verschillende manieren van invloed kan zijn op het psychosomatisch welbevinden van ouders:

(a) structurele sociale steun kan een directe relatie hebben met de concrete problemen van ouders (pijl a) en het psychosomatisch welbevinden van ouders (pijl b);

(b) structurele sociale steun kan indirect gerelateerd zijn aan het psychosomatisch onwelbevinden van ouders via hun concrete problemen (pijl $\mathrm{a}^{*} \mathrm{C}$ );

(c) structurele sociale steun kan een modererende werking op het psychosomatisch welbevinden van ouders hebben (pijl c).

Van functionele sociale steun, i.c. waargenomen steun uit de sociale omgeving, wordt aangenomen dat dit begrip pas aan de orde is wanneer ouders concrete problemen ervaren. Verondersteld wordt dat functionele sociale steun eveneens op verschillende manieren een rol kan spelen in het stressproces bij ouders met een verstandelijk gehandicapt kind:

(d) functionele sociale steun kan afhankelijk zijn van de concrete problemen van ouders, kenmerken van het verstandelijk gehandicapte kind, kenmerken van de ouders en kenmerken van de andere kinderen (pijlen $\mathrm{d} t / \mathrm{m} \mathrm{g}$ );

(e) functionele sociale steun kan een beschermende werking hebben, hetzij als moderator (pijl i), hetzij als mediator (pijlen $d^{*} h, e^{*} h, f^{*} h$ en $g^{*} h$ );

(f) functionele sociale steun kan onafhankelijk van de overige in het model opgenomen variabelen een positieve of negatieve invloed op het psychosomatisch welbevinden van ouders uitoefenen (pijl h).

\subsection{Besluit: Stressmodellen}

In dit hoofdstuk zijn drie modellen opgesteld ter verklaring van de verschillen in stress tussen ouders van een kind met een verstandelijke handicap. Deze stressmodellen zijn exploratief omdat uit theoretische en onderzoeksliteratuur weinig met zekerheid te concluderen is over de variabelen die een rol spelen in de stressprocessen bij deze ouders en over de relaties tussen deze variabelen.

In het eerste model, het zogeheten basismodel, wordt verondersteld dat het psychosomatisch onwelbevinden van ouders te verklaren is uit hun taxatie van verschillende concrete problemen, uit diverse kenmerken van het verstandelijk gehandicapte kind, zoals zijn of haar gedragsproblemen, sociale redzaamheid en lichamelijke gezondheid, uit kenrnerken van de ouders zelf, zoals hun utilitaire bronnen en persoonlijkheidskenmerken, en uit variabelen die de andere kinderen in het gezin betreffen, zoals het aantal andere kinderen en hun leeftijd.

Uit Lazarus" theorievorming kan vervolgens worden afgeleid dat de manier waarop ouders hun problemen hanteren, vooral ouders in de meest stressvolle omstandigheden zou kunnen beschermen tegen de negatieve gevolgen van deze omstandigheden voor hun welbevinden. Studies naar coping in het algemeen leveren echter weinig evidentie op voor deze gedachtengang. Aangezien er bovendien nauwelijks onderzoek verricht is naar de rol van coping in het stressproces bij ouders van een verstandelijk gehandicapt kind, worden in het tweede model, het copingmodel, 
werschillende manieren geëxpliciteerd waarop coping van belang kan zijn voor de stress van deze ouders.

Hoewel het belang van sociale steun voor ouders van een verstandelijk gehandicapt kind met meer onderzoeksbevindingen is gedocumenteerd, maken studies waarin sociale steun is opgenomen, evenmin duidelijk in welke mate en op welke wijze sociale steun zijn vaak gerapporteerde positieve functie vervult. In het derde verklaringsmodel, het sociale-steunmodel, zijn dan ook verschillende manieren aangegeven waarop steun uit de sociale omgeving een rol zou kunnen spelen in het leven van ouders van een kind met een verstandellijke handicap. 


\section{Ontwikkeling van gezinsbegeleiding}

De stress van ouders die hun verstandelijk gehandicapte kind in het eigen gezin wilden grootbrengen, kwam tijdens de Conferentie Gezinsbegeleiding (1977) voor het eerst duidelijk voor het voetlicht. Zoals reeds opgemerkt, wilden steeds meer ouders wanaf de zestiger jaren hun gehandicapte kind thuis grootbrengen (zie 1.2). $\mathrm{Zij}$ hadden tot in de jaren zeventig echter geen reële keuze tussen het kind thuis groot te brengen en het in een institutionele woonvoorziening te plaatsen. Tijdens de Conferentie Gezinsbegeleiding is dit onder de aandacht van de overheid gebracht.

De Conferentie Gezinsbegeleiding en de voorwaarden waaraan de zorg volgens de deelnemers moest voldoen om tegemoet te komen aan de wensen van ouders, worden in 4.1 weergegeven. De wijze waarop de overheid sindsdien heeft getracht aan deze wensen tegemoet te komen, komt in 4.2 aan de orde. Paragraaf 4.3 illustreert de mate waarin de overheidsmaatregelen de keuzemogelijkheden van ouders hebben doen toenemen, aan de hand van de situatie in de zorg- en dienstverlening ten behoeve van mensen met een verstandelijke handicap anno 1991.

\subsection{De Conferentie Gexinsbegeleiding (1977)}

De deelnemers aan de Conferentie Gezinsbegeleiding, ouders, hulpverleners, wetenschappers en beleidmakers, waren het erover eens dat er nogal wat schortte aan de kwaliteit van de hulpverlening ter ondersteuning van het gezin, hoe uitgebreid en geprofessionaliseerd de zwakzinnigenzorg in de jaren zeventig ook was. Men trachtte voorwaarden te formuleren waaronder het thuis grootbrengen van een kind met een verstandelijke handicap de meeste kans van slagen heeft.

De knelpunten die men signaleerde (zie de conferentieverslagen: Meiresonne, 1978; Mij ' $n$ zorg, 1978), geven enig inzicht in de toenmalige structuur- en functioneringsproblemen in de zwakzinnigenzorg. Deze knelpunten betreffen de afstemming 
van het hulpaanbod op de hulpvraag, de samenthang in het hulpaanbod en de houding van hulpverleners en ouders, terwijl er tevens lacunes in de hulpverlening werden geconstateerd.

\section{Afstemming van het hulpaanbod op de hulpvraag}

Het hulpaanbod dient primair te zijn afgestemd op de hulpvragen van (ouders van) verstandelijk gehandicapten en niet op de belangen die voorzieningen hebben bij het verstrekken van hulp. De gegeven zorg moet toegesneden zijn op de maat van de individuele hulpvrager (zie ook: Federatie van Ouderverenigingen, 1980).

De wijze van financiering en de formulering van het verstrekkingenpakket lieten in de zeventiger jaren een flexibel gebruik van voorzieningen niet toe. Het pakket kende drie door de AWBZ erkende voorzieningen: de inrichting, het gezinsvervangend tehuis en het dagverblijf. Mensen die van én van deze voorzieningen gebruik maakten, hadden automatisch recht op alle hulponderdelen van deze voorziening, ook al hadden zij ze niet nodig (overzorg). Zij konden dan geen aanspraak meer maken op de andere voorzieningen (het probleem van de dubbele verstrekking).

Mensen die gegeven de indicatiestelling niet in aanmerking kwamen voor de voorzieningen, bleven verstoken van iedere vorm van AWBZ-hulp, ook al zouden zij wel aanspraak willen maken op bepaalde onderdelen van de hulp. Dit probleem, de zogeheten onderzorg, leidde er bijvoorbeeld toe dat ouders die hun kind thuis wensten op te voeden, niet in aanmerking kwamen voor hulponderdelen van de intramurale voorzieningen.

\section{Samenhang in het hulpaanbod}

Ouders komen met hun twijfels over de ontwikkeling van het kind in eerste instantie vaak terecht bij de eerste lijns gezondheidszorg: de huisarts, het consultatieburo, de wijkverpleging, de gezinsverzorging, het algemeen maatschappelijk werk. Deze hulpverleners moeten beter worden toegerust om de handicap van het kind vroeger te kunnen signalleren, ouders met name op psychosociaal gebied beter te kunnen begeleiden, en hen indien nodig te verwijzen naar de kinderarts of de gespecialiseerde zwakzinnigenzorg. In dit kader is onder andere gesproken over de oprichting van multidisciplinair samengestelde teams voor vroegtijdige onderkenning van ontwikkelingsstoornissen.

Binnen de zwakzinnigenzorg, een "bonte lappendeken van instellingen en organisaties" (Verbraak, 1978, p. 13), zou een meer overzichtelijke structuur de bereikbaarheid en doelmatigheid van de zorg ten goede komen. Tijdens de Conferentie Gezinsbegeleiding bepleitte men een grotere samenhang in het totale hulpaanbod en een betere samenwerking tussen alle hulpverleners die betrokken zijn bij gezinnen met een verstandelijk gehandicapt kind. Deze samenwerking zou op regionaal nivo tot stand gebracht moeten worden om een optimale dienstverlening te bewerkstelligen. 


\section{Houding van hulpverleners en ouders}

De conferentiegangers meenden voorts dat hulpverleners en ouders hun houding tegenover elkaar moesten veranderen. In individuele bulpverleningscontacten moeten hulpverleners de ouders, die immers bij uitstek deskundig zijn wat hun kind(eren) betreft, te allen tijde serieus nemen en hen in hun ouderlijke verantwoordelijkheid respecteren. Terwijl de hulpverlener de neiging heeft zich aan te bieden als vriendelijke deskundige, heeft het gezin vaak meer behoefte aan een deskundige vriend. De Ruijter (1978) vermoedt dat bij een ongecorrigeerde ontwikkeling de hulpverlener steeds minder dienstbaar zal zijn aan de hulpvragende ouder. Ouders moeten daarom mondiger worden en minder afhankelijk van de hulpverlening. Participatie in de zwakzinnigenzorg zou hieraan een bijdrage kunnen leveren.

\section{Lacunes in de hulpverlening}

Tijdens de Conferentie Gezinsbegeleiding zijn tenslotte lacunes in de hulpverlening geconstateerd, en wel ten aanzien van hulp bij de opvoeding, hulp bij praktische problemen en tijdelijke opvang van het gehandicapte kind buiten het gezin.

Hulp bij de opvoeding: Ouders hebben zelf niet altijd oplossingen voor de omgangsen opvoedingsproblemen waarvoor het gehandicapte kind hen stelt. De bronnen van waaruit ouders in het algemeen hun kinderen opvoeden, traditie, inturtie en gezond verstand (Ter Horst, 1980), zijn soms ontoereikend bij verstandelijk gehandicapte kinderen en soms geblokkeerd vanwege emotionele reacties van ouders op de handicap van het kind (Oosterhof-Beugelink, 1984).

De directe sociale omgeving, familie, vrienden, buren, weet vaak evenmin antwoorden op de opvoedingsvragen, terwijl ook professionele hulpverleners in de jaren zeventig vaak een antwoord schuldig bleven. "Ik weét niet hoe een mongooltje moet leren lopen of hoe een zindelijkheidstraining gedaan zou moeten worden. Ik wét niet hoe je een kind dat erg moeilijk slaapt een goede slaapgewoonte bijbrengt, of hoe je het leert eten. Dat zit niet in onze opleiding", aldus formuleert een gespecialiseerde maatschappelijk werkende zijn onmacht (Kiers, 1977, p. 7). En hoewel deze deskundigheid in een kinderdagverblijf wel aanwezig is, ontbreekt het de leiding daar aan praktische mogelijkheden om ouders in hun situatie thuis te helpen.

Ouders kunnen zich onzeker gaan voelen uit angst dat zij door onjuiste handelswijzen het gehandicapte kind te weinig ontplooiingsmogelijkheden bieden. Om tegemoet te komen aan de behoefte van ouders en hulpverleners aan praktische hulp bij opvoedingsvraagstukken, is tijdens de conferentie gesproken over speel-o-theken, waar men ouders kan adviseren over aangepast speelgoed. Tevens werd gevraagd om een snelle ontwikkeling van vormen van pedagogische hulp die bij het gezin thuis worden verstrekt, zoals het project hometraining dat in 1975 van start was gegaan bij de Vakgroep Speciale Pedagogiek van de Vrije Universiteit van Amsterdam en de experimentele projecten die bij verschillende Sociaal Pedagogische Diensten met dit soort hulp waren opgezet. 
Hulp bij praktische problemen: Een tweede vorm van hulp die ontbrak, was taakverlichtende hulp bij praktische problemen, zoals (a) kort- of langdurende achieve oppas overdag, (b) passieve oppas op een tijdstip dat het gehandicapte kind in bed ligt, (c) hulp bij de lichamelijke verzorging en verpleging van het gehandicapte kind, (d) educatieve en recreatieve bezigheidsbegeleiding of speelhulp, (e) hulp bij huishoudelijke werkzaamheden, (f) hulp tijdens weekends of vakanties, en (g) huip bij vervoersproblemen.

Men kon de gezinsverzorging inschakelen voor hulp bij thuishoudelijke en verzorgende taken en de wijkverpleging voor hulp bij de verpleging en verzorging van een gehandicapt kind. Op beide vormen van hulp kon men echter alleen in noodsituaties en als aanvulling op hulp uit het informele circuit een beroep doen. De hulp werd voomamelijk tijdens kantooruren en slechts bij uitzondering voor langere duur verleend. Met de hoge kosten die aan de hulp verbonden waren, leidde dit ertoe dat veel minder ouders van een thuis wonend verstandelijk gehandicapt kind in aanmerking kwamen voor en gebruik maakten van deze hulp dan gewenst zou zijn op basis van de extra praktische zorg die een verstandelijk gehandicapt kind vergt (zie: Bontje \& Van der Post, 1989). Hulpvragen die niet tot het takenpakket van de gezinsverzorging en de wijkverpleging hoorden, bleven bovendien geheel onbeantwoord.

In de zeventiger jaren waren op enkele plaatsen Oppas- en Praktische Thuishulpcentrales opgezet, speciaal gericht op ouders van een (verstandelijk) gehandicapt kind. Tijdens de Conferentie Gezinsbegeleiding bepleitte men een verdere uitbouw van deze centrales.

Tijdelijke opvang buitenhuis: Tot slot was er behoefte aan vormen van hulp die ertoe bijdragen dat de ouders en de andere kinderen in het gezin zo nu en dan op adem kunnen komen, zoals een vertrouwde oppas en een vertrouwd adres waar het gehandicapte kind eén of meer nachten, een weekend of een vakantie kan logeren. Tevens werd gesproken over de mogelijkheid van residentiële opvang voor korte duur, die nodig kan zijn als het kind een paar weken beter niet thuis kan zijn, bijvoorbeeld bij een verhuizing, een ziekenhwisopname van eén van de ouders, de geboorte van een kind of echtscheidingsproblemen.

\section{Besluit: Gezinsbegeleiding}

Ouders van een kind met een verstandelijke handicap hadden in de jaren zeventig behoefte aan begeleiding van het gezin. "Gezinsbegeleiding" beoogt de balans tussen de draagkracht en de draaglast van ouders die thuis een kind met een verstandelijke handicap grootbrengen, te optimaliseren. "Gerinsbegeleiding" stelt gezinnen in staat, door een toename van hun zelfstandigheid, de taken die gezinnen gewoonlijk verrichten, ook uit te voeren wanneer er een kind met een verstandelijke handicap is geboren. "Gexinsbegeleiding" verwijst naar hulpvormen die zijn afgestemd op de hulpvragen van ouders, naar hulpverleningsmethoden waarin ouders gerespecteerd worden in hun verantwoordelijkheid en naar een flexibele en samenhangende organisatie van algemene en categoriale hulpverleningsmogelijkheden. 


\subsection{Overheidsbeleid na 1977}

De centrale overheid reageerde snel op de knelpunten in de zorg voor verstandelijk gehandicapten. Nog geen jaar na de Conferentie Gezinsbegeleiding aanvaardde de Tweede Kamer met algemene stemmen de motie van mw. Cornelissen, mw: Verkerk-Terpstra en mw. Beckers-De Bruijn, die bekend is geworden als Motie 19. Deze motie vraagt aandacht voor de gevoelens van rechtsongelijkheid die ouders van een thuis verblijvend gehandicapt kind ervaren vanwege hun ongunstige financiële en sociale positie in vergelijking met ouders wier kind in een erkende AWBZ-inrichting verblijft. De regering wordt gevraagd een studie naar deze ongelijkheid te verrichten en wegen aan te geven waarlangs deze, eventueel gefaseerd, is op te heffen.

Met het aanvaarden van Motie 19 in 1978, de eerste bemoeienis van de overheid met de problematiek van ouders die hun (verstandelijk) gehandicapte kind thuis wensen groot te brengen, erkende de overheid de noodzaak oplossingen te vinden voor deze problematiek. In de daarop volgende jaren heeft zij met verschillende nota's getracht vorm te geven aan het beleid ten aanzien van de zorg voor mensen met een verstandelijke handicap. De belangrijkste hiervan (zie schema 4.1) worden in het navolgende kort besproken.

1974 Structuumota Gezondheidszorg

1977 Conferentie Gezinsbegeleiding

1978 Motie 19

1981 Notitie Uitgangspunten voor een gecoördineerde beleidsontwikkeling ten aanzien van geestelijk gehandicapten

1983 Hulpverlening aan gezinnen met een gehandicapt kind (Eindnota Motie 19)

1983 Beleidsnota Geestelijk gehandicapten

1987 Commissie Structuur en Financiering Gezondheidszorg: Bereidheid tot verandering

1989 Zorg- en dienstverlening ten behoeve van geestelijk gehandicapten: Regeringsstandpunt

1991 Zorg - en dienstverlening ten behoeve van geestelijk gehandicapten: Werknotitie zorginnovatie verstandelijk gehandicapte personen

Schema 4.1. Nota's en adviezen ten behoeve van de zorg voor mensen met een verstandelijke handicap

Hulpverlening aan gezinnen met een gehandicapt kind (Eindnota Motie 19, 1983) Vijf jaar na de indiening van Motie $19 \mathrm{kwam}$ toenmalig staatssecretaris van Welzijn, Volksgezondheid en Cultuur, Van der Reijden, met de Eindnota Motie 19. Financielle ombuigingen en voomemens daartoe (zie Bij de Vaate, 1986) hadden in de loop van deze jaren de financiële ongelijkheid tussen ouders met een gehandicapt kind thuis en ouders met een gehandicapt kind in een intramurale voorziening voor een belang- 
rijk gedeelte opgeheven. In de Eindnota Motie 19 ligt de nadruk dan ook op een andere belemmering voor het thuis grootbrengen van een gehandicapt kind: het gebrek aan voldoende toegankelijke en samenhangende voorzieningen voor thuis verblijvende gehandicapten. Aangezien ouders hierdoor moeite hebben op het juiste moment, voor de juiste duur en in de gewenste omvang hulp te krijgen, verkeren zij in voortdurende zorg omtrent de continuiteit van de hulpverlening. In aansluiting op de gewijzigde hulpvragen dient het overheidsbeleid daarom gezinsbegeleiding centraal te stellen.

\section{Beleidsnota Geestelijk gehandicapten (1983)}

Samen met de Eindnota Motie 19, die betrekking heeft op alle gehandicapten, bood de staatssecretaris in mei 1983 de beleidsnota Geestelijk gehandicapten aan de Tweede Kamer aan. Deze nota beschrijft het toenmalige systeem van zorg-, hulpen dienstverlening ten behoeve van mensen met een verstandelijke handicap en het gezin waartoe zij behoren.

Als belangrijkste manco wijst de nota op de onvoldoende verschuiving van het zwaartepunt in de zorg van de intra- naar de semi- en extramurale hulpverlening. Deze verschuiving werd voor de gezondheidszorg in haar geheel al in de structuurnota Gezondheidszorg (1974) bepleit, zij het toen voomamelijk om financiële redenen (zie 1.2). Staatssecretaris Van der Reijden noemt in zijn beleidsnota de te verwachten kostenbesparingen slechts als eén van de motieven om in het begin van de jaren tachtig een verdere versterking van de ambulante functies in de zorg voor verstandelijk gehandicapten na te streven. De toegenomen behoefte aan gezinsbegeleiding, in de vorm van oppas, speelhulp, pedagogische advisering, behandeling en emotionele ondersteuning, is een even belangrijke reden. Opheffing van kwantitatieve en kwalitatieve tekorten in de zorg is dan ook eén van de hoofdthema's van het beleid dat hij in de nota voorstelt.

De minder intensieve hulpvormen zijn voorts in overeenstemming met de doelstelling van het overheidsbeleid, zoals geformuleerd in de notitie Uitgangspunten voor een gecoördineerde beleidsontwikkeling ten aanzien van geestelijk gehandicapten (19801981): het beleid moet gericht zijn op erkenning van de verstandelijk gehandicapte als volwaardig lid van de samenleving en er moeten voorwaarden gecreěerd worden om te bereiken dat verstandelijk gehandicapten ook als zodanig worden geaccepteerd. Dat de gewenste accentverschuiving nog onvoldoende gestalte had gekregen, wijt de staatssecretaris aan het gemis aan structurele financiering van minder intensieve vormen van gezinsbegeleiding, de formulering en financiering van het AWBZ-verstrekkingenpakket (zie 4.1), de niet optimale samenwerking tussen voorzieningen en het ontbreken van een kader voor geïntegreerde planning van intra-, semi- en extramurale voorzieningen.

De beleidsnota Geestelijk gehandicapten schetst een model voor de zorg aan mensen met een verstandelijke handicap dat beoogt antwoord te geven op alle zorgvragen. Dit model bestaat uit een functiestelsel, waarbij onder een "functie" een bundeling van activiteiten wordt verstaan waarmee antwoord gegeven kan worden op (een) 
bepaalde zorgvra(a)g(en). Naast de functie van vroegtijdige onderkenning van ontwikkelingsstoomissen, die de overheid beschouwt als voorportaal van de zorg voor (verstandelijk) gehandicapten, onderscheidt de nota: (a) voorlichting, advies en verwijzing; (b) observatie en diagnostiek; (c) begeleiding; waaronder gezinsbegeleiding; (d) onderwijs en vorming; (e) arbeid en dagbesteding; (f) vrijetijdsbesteding; (g) verzorgd verblijf, met mogelijkheden tot een flexibele verblijfduur; (h) behandeling; en (i) verpleging.

De functies moeten regionaal geordend worden om de overzichtelijkheid van het zorgsysteem, de samenhang tussen de onderdelen en de geografische bereikbaarheid ervan te vergroten en de kostenbeheersing te vergemakkelijken. Op regionaal nivo moeten de voorzieningen formeel gaan samenwerken als waarborg voor de continuiteit van de zorg. Tevens moet er bestuurlijk geregionaliseerd worden en moeten de lagere overheden, provincies en gemeenten, financiële kaders toegerekend worden. Als voorwaarde voor een toekomstig zorgsysteem maakt de beleidsnota duidelijk dat wijzigingen in de zorg binnen de beschikbare financiële kaders dienen plaats te vinden. De overheid verwachtte begin jaren tachtig namelijk dat een versterking van de ambulante functies de behoefte aan uitbreiding van intramurale voorzieningen zou doen verminderen.

\section{Zorg- en dienstverlening ten behoeve van geestelijk gehandicapten: Regerings- standpunt (1989)}

De nota Geestelijk gehandicapten is de eerste nota met beleidsvoomemens ten aanzien van de zorg voor verstandelijk gehandicapten. De regering achtte het wenselijk de verdere ontwikkeling van het toekomstmodel dat haar in deze nota voor ogen stond, in bredere kring te laten plaatsvinden. Verschillende organisaties brachten daartoe na 1983 adviezen aan de regering uit, zoals de Nationale Raad voor de Volksgezondheid en de Nationale Raad voor het Maatschappelijk Welzijn (NRV/NRMW, 1986, 1987, 1988), de Ziekenfondsraad (1987a) en de Federatie van Ouderverenigingen $(1987,1989)$.

Als voorlopige afsluiting van deze discussie bood staatssecretaris Dees van WVC in maart 1989 het regeringsstandpunt Zorg- en dienstverlening ten behoeve van geestelijk gehandicapten aan de Tweede Kamer aan. Hoewel hierin enige aandacht wordt besteed aan onderwerpen die buiten de specifieke zwakzinnigenzorg vallen, zoals onderwijs en arbeid, beperken wij de bespreking tot "de zorg in engere zin".

De regering is evenals de adviserende instanties van mening dat de hulpvraag van de verstandelijk gehandicapte en zijn of haar ouders de fundering en de uiteindelijke legitimering vormt van de zorg- en dienstverlening. Het zorgsysteem moet zich daarom ontwikkelen van een voorzieningengericht naar een cliëntgericht systeem, dat zorg op maat kan bieden. Staatssecretaris Dees noemt een functiegericht verstrekkingenstelsel en regionalisatie en regionale samenwerking als voorwaarden voor een dergelijk systeem. 
Functiegericht verstrekkingenstelsel: In een functionele benadering is het hulpaanbod losgekoppeld van de voorzieningen en gebaseerd op de hulpvragen van verstandelijk gehandicapten en hun ouders. De Nationale Raden en de Federatie van Ouderverenigingen geven in hun adviezen opsommingen van alle mogelijke hulpvragen en stemmen daarop het hulpaanbod af.

De Ziekenfondsraad benadert de vernieuwing van het verstrekkingenpakket niet varuit zorginhoudelijke vragen, maar vanuit de aanbodzijde: dit advies betreft alleen de hulp die wanuit de sociale ziektekostenverzekering wordt gefinancierd. Het voorziet in ten AWBZ-verstrekking geestelijk gehandicaptenzorg met 14 deelverstrekkingen: verblijf, verzorging, verpleging, behandeling (gedragswetenschappelijk, paramedisch en geneeskundig), begeleiding (gericht op de verstandelijk gehandicapte: gedragswetenschappelijk, activerend en beschermend; gericht op de ouders en het gezin: gedragswetenschappelijk), onderzoek (gedragswetenschappelijk en geneeskundig), regelmatig vervoer en farmaceutische hulp. Deze deelverstrekkingen, met name de eerste drie, moeten dag en nacht, in deeltijd (vier tot acht uur) en kortdurend (minder dan vier uur per dag) geboden kunnen worden.

In de regio's Amersfoort en Oost-Gelderland zijn in 1988 onder verantwoordelijkheid van de Ziekenfondsraad experimenten gestart met een functiegerichte verstrekkingensystematiek (Ziekenfondsraad, 1987b). Bij deze experimenten zijn alle deelverstrekkingen betrokken. Tevens zijn in beide proefregio's gelden uit de AWBZ ter beschikking gesteld woor zogeheten logeerplaatsen, waar thuis wonende verstandelijk gehandicapten maximaal zeven etmalen per maand kunnen logeren ter ontlasting van het gezin (Federatie van Ouderverenigingen, 1989). De overheid hecht veel belang aan deze hulpvorm: "De logeerfunctie zal te zijner tijd een plaats kunnen krijgen in het gewijzigde verstrekkingenstelsel naast andere intermitterende functies als weekendopvang en de kortverblijffunctie in inrichtingen" (Zorg - en dienstverlening ten behoeve van geestelijk gehandicapten: Regeringsstandpunt, 1988-1989, p. 32). Praktische Thuishulp is niet betrokken bij de experimenten. De overheid en de Ziekenfondsraad (1987a) zijn van mening dat Praktische Thuishulp thuishoort bij de algemene voorzieningen in de eerste lijns gezondheidszorg en niet bij de specifieke voorzieningen in de zorg woor verstandelijk gehandicapten.

Rapportages over de experimenten van het Instituut voor Sociaal Wetenschappelijk Onderzoek van de Katholieke Uniwersiteit Brabant, IVA, (Denis \& Van den Borne, 1989, 1990; Van den Borne, Denis \& Maas, 1988) en de begeleidingscommissie van de experimenten (BOEGG, 1990) hebben de Ziekenfondsraad enerzijds doen concluderen dat het nieuwe verstrekkingenstelsel zoals verwacht meer mogelijkheden biedt om tegemoet te komen aan de gevarieerde hulpvragen dan het oude stelsel.

Anderzijds maken deze rapportages duidelijk dat er geen vloeiende overgang is tussen de toewijzing en de feitelijke realisering van de zorg. De bestaande wachtlijsten zijn hieraan debet, evenals het spanningsveld tussen oude en nieuwe structuren dat de volgens de Ziekenfondsraad noodzakelijke regionale samenwerking tot in 1990 belemmerd heeft. Om de praktische uitvoerbaarheid van het nieuwe systeem 
goed te kunnen evalueren, heeft de Ziekenfondsraad daarom besloten de experimenten, die oorspronkelijk in 1991 zouden worden afgerond tot 1992 te continueren (Ziekenfondsraad, 1990a). In dit extra jaar wordt getracht enige versnelling aan te brengen in het proces van regionale samenwerking.

Regionalisatie en regionate samenwerking: De regering noemt regionalisatie en regionale samenwerking als tweede voorwaarde voor een systeem dat zorg op maat kan bieden. De regionale samenwerking moet betrekking hebben op de informatievoorziening, de indicatiestelling, de zorgtoewijzing, de beroepsmogelijkheden en de toestemming door de verzekeraars, kortom op het hele proces dat van de hulpvraag naar het hulpaanbod loopt. Tevens moet een regionaal samenwerkingsverband de hulpvragen en hulpantwoorden registreren en op basis hiervan planningsadviezen uitbrengen.

Een belangrijke aanzet tot samenwerking is reeds gegeven door de totstandkoming van regionale overlegorganen zwakzinnigenzorg (ROZ). Bij een verdere uitbouw van deze organen stelt de regering ter vermijding van bureaucratische neveneffecten voor het accent meer te leggen op de uitvoering dan op het bestuurlijk overleg. Alle instellingen in een regio en met het oog op toekomstige wetgeving ook de regionale verzekeraars dienen door samenwerkingscontracten bij de inhoud en de uitvoering van de zorg betrokken te zijn. De aanstelling van een projectfunctionaris moet de totstandkoming van regionale samenwerking stimuleren.

Zorg- en dienstverlening ten behoeve van geestelijk gehandicapten: Werknotitie zorginnovatie verstandelijk gehandicapte personen (1991)

In juli 1991 bood staatssecretaris Simons van WVC de Werknotitie zorginnovatie verstandelijk gehandicapte personen aan de Tweede Kamer aan, ook wel bekend als de nota Verstandig veranderen. Hij is daarin van mening dat de toegenomen differentiatie in het zorgaanbod heeft geleid tot een grotere flexibiliteit, een betere afstemming op de hulpvragen en meer keuzemogelijkheden voor (ouders van) mensen met een verstandelijke handicap.

Simons meent echter evenzeer dat het aanbod nog teveel is "voorgesorteerd" en dat "het uitgangspunt dat de verstandelijk gehandicapte persoon moet worden ingepast in de beschikbare zorgstructuur...nog niet [is] vervangen door het uitgangspunt dat de zorgstructuur zich zo goed mogelijk moet aanpassen aan de wensen van de verstandelijk gehandicapte persoon" (Zorg-en dienstverlening ten behoeve van geestelijk gehandicapten: Werknotitie zorginnovatie verstandelijk gehandicapte personen, 1990-1991, p. 13). Geadviseerd door de Ziekenfondraad (1990b), meent Simons de positie van de zorgvrager te kunnen versterken door (ouders van) gehandicapten aanspraak te laten maken op een eigen budget waarmee zij zelf hun "verzorgingsarrangement" kunnen opstellen, daarbij professioneel ondersteund door een onafhankelijke case-manager. Hij kondigt experimenten met deze clièntgebonden budgetfinanciering aan. 
De invoering van een functioneel verstrekkingenpakket blijft een belangrijke plaats innemen bij de wijziging van het zorgstelsel en is voorzien per 1 januari 1993. Staatssecretaris Simons bepleit een vereenvoudiging van het functiestelsel. Hij omschrifft vier globale functies: verzorgd verblijf, begeleiding, dagbesteding en thuiszorg. Hieronder vallen alle huidige voorzieningen en in de toekomst ook pleegzorg en begeleiding bij zelfstandig wonen. Door de rechten van (ouders van) verstandelijk gehandicapten in functionele termen te omschrijven, worden de monopolieposities van instellingen beèndigd: zij mogen een breed scalla van zorgfuncties gaan leveren (schaaloptimalisering). Ook de substitutieregeling die vanaf juli 1991 van kracht is, moet bijdragen aan een grotere differentiatie in het zorgaanbod. Voorzieningen mogen een deel van hun budget aan andere zorgvormen besteden, ook aan hulpvormen die de draagkracht van ouders vergroten.

Decentralisatie blijft eveneens een voorwaarde voor een flexibel zorgsysteem. De regionale samenwerking moet naar Simons' oordeel in een groot aantal regio's echter beter ontwikkeld worden. Hij meent dat de zorgverleners en niet de overheid hiervoor primair verantwoordelijk zijn: er is dan ook geen wetgeving op dit punt te verwachten. Verplichte regionale samenwerking en daarmee vaststelling van regionale budgetten, staan haaks op het uitgangspunt dat in de nota Werken aan zorgvernieuwing (1989-1990) is vasigelegd: zorgverzekeraars en zorgaanbieders moeten in vrijheid overeenkomsten kunnen sluiten om de marktwerking tot zijn recht te laten komen. Bovendien meent Simons dat de samenwerking vooral functionele kenmerken moet hebben en miet voomamelijk territoriale, zoals in de experimenten van de Ziekenfondsraad het geval is. De Ziekenfondsraad reageerde op deze breuk in het overheidsbeleid, namelijk een vrijwillige in plaats van een verplichte regionale samenwerking, met het alsnog beëindigen van zijn experimenten in 1991 (Delfgauw, 1991).

\section{Besluit: Overheidsmaatregelen}

De vernieuwingen in de zorg voor mensen met een verstandelijke handicap zijn niet los te zien van de herstructurering in de gezondheidszorg in haar geheel, waarvoor de structuumota Gezondheidszorg reeds in 1974 de toon zette. Het uiteindelijke doel vain deze vernieuwingen is en blijft de grotere zelfstandigheid en emancipatie van mensen met een verstandelijke handicap, ook al hebben maatschappelijke ontwikkelingen en adviezen geleid tot aanpassingen in de wijze waarop de overheid meent aan deze vernieuwingen vorm te moeten geven.

Vooral het advies van de Commissie Structuur en Financiering Gezondheidszorg, bekend geworden onder de naam van haar voorzitter prof. dr. W. Dekker (1987), is op de vormgeving van de herstructureringen van invloed geweest. Dit advies pleit voor een verminderde wet- en regelgeving, de introductie van marktwerking en concurrentie door een toename in de verantwoordelijkheden van zorgaanbieders en zorgverzekeraars en een versterking van de positie van de consument, en de invoering van eén ziektekosten- ofwel "zorgverzekering". Inhoudelijk blijft de nadruk echter ook in de jaren negentig liggen op preventie, thuiszorg, eerste lijns voorzie- 
ningen, afstemming van het aanbod op de vraag, een functionele basis voor de zorg en een functionele samenhang tussen regionale instellingen.

\subsection{Zorg- en dienstverlening aan gexinnen met een verstandelijk gehandicapt kind anno 1991}

Vanaf de aanvaarding van Motie 19 in 1978 heeft de overheid getracht haar beleid af te stemmen op de veranderde hulpvragen van ouders van een kind met een verstandelijke handicap. In hoeverre dit hun mogelijkheden om het kind in het eigen gezin groot te brengen, daadwerkelijk heeft doen toenemen, wordt in het navolgende geillustreerd aan de hand van de problemen die volgens de deelnemers aan de Conferentie Gezinsbegeleiding het thuis opvoeden van een verstandelijk gehandicapt kind tot in de jaren zeventig in de weg stonden (zie 4.1).

\section{Afstemming van het hulpaanbod op de hulprraag}

Het hulpaanbod was in de jaren zeventig niet afgestemd op de hulpvragen van (ouders van) verstandelijk gehandicapten maar op de door de AWBZ erkende voorzieningen. Dit probleem lijkt te kunnen worden opgelost met het van kracht worden van de substitutieregeling, de invoering van een functionele verstrekkingensystematiek en de mogelijkheid tot een cliëntgebonden budgetfinanciering.

De substitutieregeling stelt alle instellingen in staat nieuwe hulpvormen en hulponderdelen van andere voorzieningen te verzorgen, waaronder zorgvormen die de draagkracht van het gezin vergroten. Op de hulp van een pakket dat is afgestemd op een functionele verstrekkingensystematiek kunnen alle (ouders van) verstandelijk gehandicapten een beroep doen, ongeacht de verblijfplaats van de gehandicapte, de functies waarvan hij of zij daarnaast gebruik maakt en de plaats waar de hulp verleend wordt. (Ouders van) verstandelijk gehandicapten hebben tenslotte meer inspraak in de vormgeving van hun eigen zorgbehoefte wanneer zij de beschikking hebben over een eigen budget.

Van de drie maatregelen is alleen de substitutieregeling vanaf juli 1991 van kracht. Er moet nog worden bezien in hoeverre deze regeling tot een verdere differentiatie in het hulpaanbod leidt. Met de cliëntgebonden budgetfinanciering moet nog worden geèxperimenteerd en een functioneel verstrekkingenpakket wordt op zijn vroegst in 1993 ingevoerd.

De invoering van deze drie maatregelen houdt niet automatisch in dat men de hulp waarvoor men geïndiceerd is, ook werkelijk ontvangt. Op verschillende punten in de zorg voor verstandelijk gehandicapten zijn al langer capaciteitsproblemen. De druk op de huidige wachtlijsten, onder andere voor woonvoorzieningen, zou op de langere termijn mede door een functiegerichte indicatiestelling kunnen afnemen. Men kan dan gebruik maken van de diverse functies van instellingen zonder van het totale aanbod gebruik te hoeven maken. Een aanzienlijke reductie van de bestaande wachtlijsten is op de korte termijn echter niet te verwachten, ook al omdat het totale budget voor de zorg gelijk blijft. Bovendien zal de zorg pas op de langere termijn 
kunnen voldoen aan de nieuwe hulpvragen die ontstaan wanneer ouders meer inspraak krijgen in de vormgeving van de hulp. Er ontstaan wellicht nieuwe wachtlijsten voor de kleinschalige hulp waaraan ouders volgens staatssecretaris Simons bijvororbeeld behoefte hebben.

Pas in de loop van de jaren negentig kan worden nagegaan of de maatregelen tot een verdere differentiatie in het hulpaanbod hebben geleid en of "de zorgverlening .... hierdoor gekenmerkt wordt dat er (binnen redelijke grenzen, dat wil zeggen de eigen verantwoordelijkheid van de burgers moet niet in het geding komen) op alle zorgvragen antwoorden gegeven worden" (Geestelijk gehandicapten, 1982-1983, p. $51)$.

\section{Samenhang in het hulpaanbod}

In de jaren zeventig bestond er te weinig samenhang en inhoudelijke afstemming tussen de onderdelen van het totale hulpaanbod. Tijdens de Conferentie Gexinsbegeleiding constateerde men in de eerste plaats problemen tussen de algemene en de categoriale hulpverlening, met name in de verwijzing van de allgemene eerste lijns gezondheidszorg naar de kinderarts en de gespecialiseerde zwakzinnigenzorg.

Sindsdien zijn ongeveer 60 teams voor Vroegtijdige Onderkenning van Ontwikkelingsstoomissen (VTO) opgericht (bron: Landelijke Commissie VTO, Rijswijk). Deze richten zich op alle (ouders van) kinderen tot zeven jaar met een aanwezige, vermoedelijke of dreigende achterstand op lichamelijk, psychisch of sociaal gebied. In VTO-teams werken alle instellingen en personen in de jeugdhulpverlening samen om ouders en hulpverleners te adviseren en indien nodig over te gaan tot nader onderzoek, behandeling of begeleiding. Medische, psychologische en maatschappelijke disciplines zijn in deze teams vertegenwoordigd (Kuipers \& Van der Velden, 1986).

Het is niet bekend hoeveel ouders via VTO-teams in de zorg voor verstandelijk gehandicapten terechtkomen, omdat een landelijk informatiesysteem op het terrein van VTO ontbreekt. Wel is duidelijk dat steeds meer ouders zich bij VTO-teams aanmelden (van ruim 300 in 1983 tot ruim 1300 in 1988) en dat de aanmeldingsproblematick in de loop van deze jaren complexer is geworden, met een afname van somatische en een toename van opvoedings- en gedragsproblemen (Beerens, 1990). Dit wijst erop dat het totale hulpaanbod voor ouders van een kind met een verstandelijke handicap mede door het ontstaan van een VTO-netwerk meer samenhang is gaan vertonen.

VTO mag niet tot een aparte categorie van hulpverlening of zelfs een afzonderlijk instituut uitgroeien. De overheid is van mening dat de reguliere zorgorganisaties onderling afspraken moeten maken over de wijze waarop zij met ontwikkelingsstoomissen omgaan. De goede samenwerking die dit vereist, kan op gespannen voet staan met een effectieve uitvoering van VTO. 
In de tweede plaats moesten regionalisatie en samenwerking tussen alle personen en instellingen die binnen een regio werkzaam zijn in de gespecialeerde zorg- en dienstverlening ten behoeve van mensen met een verstandelijke handicap, meer samenhang en afstemming tot stand brengen. Bepleit en gestimuleerd door de landelijke overheid hebben de decentralisatie en de regionale samenwerking in de jaren tachtig steeds meer vorm gekregen. Uit de beschrijving van de gefaseerde ontwikkeling van regionale overlegorganen zwakzinnigenzorg (Witteveen, 1985) blijkt dat de totstandkoming van een aaneengesloten circuit van zorg niet zonder meer tot een goed functionerende samenwerking leidt.

Witteveen constateert in 1985 dat veel overlegorganen in een eerste fase zijn blijven steken, waarin men het regionale krachtenveld in kaart tracht te brengen en overeenstemming tracht te bereiken over de doelstellingen, taken, middelen, deelnemers en besluitvormingsprocedures. De richtlijn in het regeringsstandpunt Zorg - en dienstverlening ten behoeve van geestelijk gehandicapten (1988-1989) dat het accent meer op de uitvoering en minder op het bestuurlijk overleg moet komen te liggen (zie 4.2), impliceert dat de meeste overlegorganen zich in 1989 in een tweede fase bevonden, waarin men de in eigen kring gesignaleerde behoeften en knelpunten gezamenlijk begint aan te pakken. In een derde fase groeit tenslotte met de afname van het onderlinge wantrouwen het besef dat men samen verantwoordelijk is voor een goed functionerende zorgverlening. Dit moet bekrachtigd worden door bindende afspraken gericht op de afstemming van het totale aanbod op de vragen uit de regio.

Vanaf eind jaren tachtig is op veel plaatsen een begin gemaakt met de realisering van de derde samenwerkingsfase door de behandeling van hulpvragen in regionale indicatie- en zorgtoewijzingscommissies. Hoewel als gevolg van gevestigde structuren "in een groot aantal regio's" de samenwerking in deze commissies nog niet volwaardig is, zoals staatssecretaris Simons in zijn Werknotitie zorginnovatie verstandelijk gehandicapten personen (1990-1991) opmerkt, getuigen deze commissies van een toegenomen samenhang in het zorgaanbod. De bureaucratisering waarmee deze overlegstructuren bijna noodzakelijkerwijs gepaard gaan, kan echter een negatieve invloed op de uitvoering van de hulp hebben.

\section{Houding van hulpverleners en ouders}

Een volgend knelpunt dat tijdens de Conferentie Gezinsbegeleiding naar voren werd gebracht, betrof het feit dat hulpverleners zich teveel als deskundige autoriteit en te weinig als "vriend" of samenwerkingspartner opstelden in hun contacten met ouders, terwijl ouders te afhankelijk en te weinig mondig waren. Ouders zijn sindsdien meer in de gelegenheid gekomen vorm te geven aan hun ouderlijke verantwoordelijklheid.

Op individueel nivo zijn er meer informele contacten tussen instellingen en ouders. Enige voorbeelden daarvan zijn het zogeheten "schriftje" waarin de ouders en de leiding van een school of dagverblijf elkaar dagelijks informeren over de situatie thuis en in de woorziening, het huisbezoek, de vrijwillige hulp die met name moeders aan de voorzieningen geven en de participatie van ouders in teambesprekingen van hun kind. Bij recent ontwikkelde hulpwormen, zoals Praktusch Pedagogische Gezins- 
begeleiding, Praktische Thuishulp, Weekendopvang en de logeertuizen, komt de ouderlijke verantwoordelijkheid tot uitdrukking in alle fasen van de hulpverlening.

Formele contacten tussen ouders en instellingen zijn eveneens steeds meer tot stand gekomen. In 1983 is bijvoorbeeld een model-intentileverklaring inzake individuele ouderparticipatie opgesteld door het Werkverband van Ouders Rond Intematen en de Nationale Ziekenhuisraad, waarin onder andere het recht op klachtenbehandeling en het recht op privacy bij registratie en rapportage geregeld zijn (Van der Meulen, 1989).

In de jaren tachtig heeft ook de collectieve ouderparticipatie steeds meer vorm gekregen: er zijn model-samenwerkingsovereenkomsten ten behoeve van ouderraden bij intra- en semi-murale voorzieningen opgemaakt en medezeggenschapsraden in het onderwijs ingesteld. Tevens zijn ouders meestal vertegenwoordigd in de besturen van voorzieningen en participeren zij in overlegsituaties op regionaal, provinciaal en landelijk nivo.

Er blijkt vanaf de jaren zeventig veel verbeterd te zijn in de relaties tussen ouders en hulpverleners. Wel moet worden afgewacht in hoeverre deze relaties onder druk komen te staan nu de overheid meer terugtreedt en beide partijen meer verantwoordelijkheden krijgen in de zorg- en dienstverlening. De relaties tussen de verstandelijk gehandicapte met zijn of haar recht op zelfbeschikking, diens ouders met hun ouderlijke verantwoordelijkheid en de hulpverleners met hun professionele verantwoordelijkheid, zullen echter zelden zonder conflicten zijn.

\section{Lacunes in de hulpverlening}

Tijdens de Conferentie Gezinsbegeleiding is tenslotte geconstateerd dat er te weinig hulp bij de opvoeding, hulp bij praktische problemen en tijdelijke opvang van het verstandelijk gehandicapte kind buiten het gezin was.

Hulp bij de opwoeding: In de jaren zeventig is gevraagd naar praktische vormen van hulp bij de opvoeding. Sindsdien zijn ongeveer 600 speel-o-theken opgericht. Deze beogen bij te dragen aan de optimale ontwikkeling van de capaciteiten en vaardigheden van kinderen door eventueel aangepast speelgoed uit te lenen en ouders te adviseren inzake spelen en speelgoed. Ongeveer een kwart van de speel-o-theken is speciaal gericht op (verstandelijk en lichamelijk) gehandicapte kinderen. De meeste daarvan zijn verbonden aan instellingen, zoals kinderdagverblijven en intramurale voorzieningen, en worden door vrijwilligers bemand (bron: Stichting Spel- en Opvoedingsvoorlichting, Den Haag).

De projecten die op een praktische manier bij het gezin thuis opvoedingshulp gaven (zie 4.1), zijn het afgelopen decennium uitgegroeid tot Praktisch Pedagogische Gezinsbegeleiding (PPG). De ontwikkeling van over het land verspreide projecten tot een vast omlijnde hulpvorm was aanvankelijk mogelijk dankzij subsidies van het Nederlands Comité voor Kinderpostzegels en overbruggingssubsidies van het ministerie van WVC. Na de beleidsnota Geestelijk gehandicapten (1982-1983) is in 
1985 door een extra verhoging van de overheidssubsidies de mogelijkheid ontstaan PPG vanuit Sociaal Pedagogische Diensten te organiseren.

Vanaf 1986 wordt Pralktische Pedagogisch Gezinsbegeleiding, voorzover verstrekt vanuit Sociaal Pedagogische Diensten, structureel gefinancierd. Hiermee is de tijdelijke projectvorm vervangen door de blijvende afdelingsworm. In 1989 is PPG onder de werkingssfeer van de AWBZ gebracht en anno 1991 is aan alle Sociaal Pedagogische Diensten een afdeling Praktisch Pedagogische Gezinsbegeleiding verbonden.

Hulp bij praktische problemen: Een aantal projecten Praktische Thuishulp en Oppashulp kreeg tot aan het begin van de jaren tachtig financiële steun van fondsen, vooral van het Nederlands Comité voor Kinderpostzegels en het Nationaal Revalidatie Fonds. Dankzij deze middelen werd aangetoond dat gezinnen geholpen zijn met "een paar extra handen thuis" (NIPTEL, 1987). Hierop trokken de fondsen zich terug om de verantwoordelijkheid over te laten aan de landelijke overheid.

Na tijdelijk de subsidiëring van een aantal projecten te hebben overgenomen, verleent de overheid vanaf 1991 een structurele subsidie aan de provincies voor de coördinatie van het vrijwilligerswerk ten behoeve van praktische hulp aan gezinnen met een gehandicapte huisgenoot. In elke regio kan hiermee een coördinator aangesteld worden die de vrijwilligers aan de gezinnen koppelt. Geadviseerd wordt (Ziekenfondsraad, 1990c) de coördinatoren een plaats te geven bij de gezinsverzorging of het kruiswerk.

Hoe de subsidieregeling gaat uitwerken voor ouders van een verstandelijk gehandicapt kind, moet in de praktijk nog blijken. Het is mogelijk dat de huidige problemen van de projecten die samenhangen met het feit dat men grotendeels met vrijwilligers moet werken, voor een deel afnemen. Wellicht loopt door een gecoördineerde werving het tekort aan gemotiveerde en breed inzetbare vrijwilligers terug. De continuiteit van de hulpverlening, altijd een kwetsbaar punt in vrijwilligersorganisaties, kan verbeteren wanneer de coördinatie en organisatie in handen komt te liggen van een betaalde kracht. Wellicht wordt ook de psychologische bereiklsaarheid vergroot door de hulp vanuit algemene kaders op te zetten.

Anderzijds is de kans aanwezig dat ouders van een verstandelijk gehandicapt kind te weinig aan bod komen nu de hulp vanuit de algemene gezondheidszorg wordt geleverd. Hun hulpvragen lijken zo eenvoudig dat deze mogelijkerwijs niet binnen de indicatiecriteria zullen vallen. Tevens is er het gevaar dat het hulpaanbod versnipperd blijft. De praktische hulpvragen van ouders van verstandelijk gehandicapten lopen nogal uiteen: oppas overdag, 's avonds, gedurende weekends of vakanties, hulp bij verzorging, verpleging of huishoudelijke taken, bezigheidsbegeleiding, en dergelijke. Deze vragen kunnen worden beantwoord door vrijwilligers en professionele betaalde krachten, door de algemene en de categoriale zorg en door ambulante, semi- en intramurale categoriale voorzieningen. 
Door in de nieuwe verstrekkingensystematiek meerdere instellingen de mogelijkheid te geven (onderdelen van) Praktische Thuishulp te verzorgen, is een goede samenwerking van essenticel belang om de ouders duidelijkheid ten aanzien van het aanbod te kunnen bieden, de continuitteit van de zorg in individuele gezinnen te kunnen garanderen, een helder inzicht in de behoeften van deze groep van ouders te verkrijgen alsmede een goed beeld van de mate waarin het totale aanbod hierop aansluit.

Tijdelijke opvang buitenshuis: Tijdens de Conferentie Gezinsbegeleiding is gevraagd naar hulp die ertoe bijdraagt dat de ouders en de andere kinderen in het gezin zo nu en dan even op adem kunnen komen. Het ging voomamelijk om tijdelijk verbliff van het gehandicapte kind buiten het gezin. Naast de zeven kortverblijftehuizen die tussen 1960 en 1970 tot stand kwamen (Te Veldhuis, 1984), zijn plaatselijk initiatieven ontplooid voor tijdelijke opvang buitenshuis. Een beperkt aantal Praktische Thuishulpcentrales kan een beroep doen op gastgezinnen die voor een dag, een weekend of een vakantie verstandelijk gehandicapten in huis opnemen.

In een aantal regio's bieden vakantieplaatsingen in intra- en semi-murale voorzieningen enige soelaas als ouders de vakantie zonder hel gehandicapte kind willen doorbrengen. Voorts zijn in 1989 zeven logeerhuizen opgericht. Per huis kunnen vijftig gezinnen maximaal zeven etmalen per maand gebruik maken van de mogelijkheid het gehandicapte kind in een verantwoorde omgeving te laten logeren. In Oost-Gelderland en Amersfoort zijn logeerplaatsen met dezelfde doelstelling (zie 4.2). Nadat gebleken was dat de logeerhuizen in een behoefte voorzien (Federatie van Ouderverenigingen, 1990a), zijn er in 1991 vijf logeerhuizen bij gekomen.

Tenslotte zijn de laatste jaren de mogelijkheden voor Weekendopvang in intra- en semi-murale woon- en dagverblijfvoorzieningen toegenomen (Krol, 1990). De woonvoorzieningen realiseren deze opvang soms in de groepen als een vaste bewoner thet weekend thuis doorbrengt. Deze Weekendopvang is vooral te beschouwen als gewenning aan een definitieve uithuisplaatsing, de zogeheten gefaseerde opname.

Soms organiseren woonvoorzieningen Weekendopvang in aparte locaties. Deze opvang is evenals de Weekendopvang die sommige dagverblijven organiseren, vooral te beschouwen als ondersteuning voor gezinnen die uithuisplaatsing van het gehandicapte kind op korte termijn niet overwegen, maar wel zo nu en dan op adem willen komen. Deze tweede vorm van Weekendopvang vertoont sterke overeenkomsten met de logeerhuizen: hoewel gezinnen ook door de week van de logeerhuizen gebruik kunnen maken, blijkt dat de meeste gezinnen vooral in de weekends een beroep (willen) doen op deze opvangmogelijkheid (Federatie van Ouderverenigingen, 1990a).

Hoewel de overheid reeds in 1983 erkende dat "alleen wanneer ouders regelmatig adempauzes gegund worden, zij hun veeleisende opvoedingstaak zonder kleerscheuren kunnen volbrengen" (Geestelijk gehandicapten, 1982-1983, p. 35), is dit manco 
niet structureel opgelost. In de loop van de jaren tachtig zijn er weliswaar meer mogelijkheden gekomen voor tijdelijke opvang van het verstandelijke gehandicapte kind buiten het gezin, maar deze hulp is anno 1991 niet landelijk beschikbaar. Naar verwachting zal de nieuwe verstrekkingensystematiek ook de functies "logeren" en "verzorgd verblijf voor korte duur" omvatten, zodat de mogelijkheden voor tijdelijke opvang buitenshuis in de loop van de jaren negentig zullen toenemen.

\section{Besluit: Zorg- en dienstverlening anno 1991}

Voor ouders die dat wensen is het in 1991 in een aantal opzichten eenwoudiger een kind met een verstandelijke handicap thuis groot te brengen dan het voordien was. Er zijn en worden nog steeds hulpvormen ontwikkeld die aansluiten bij de hulpvragen van ouders en hen door hun wijze van werken in staat stellen vorm te geven aan hun ouderlijke verantwoordelijkheid. Tevens is de relatie tussen de ouders en de zwakzinnigenzorg verbeterd door formele en informele participatie van ouders in voorzieningen, besturen en overlegorganen.

Er is meer samenhang in het hulpaanbod gekomen door een betere regionale samenwerking tussen categoriale hulpverleners onderling en tussen de algemene en de categoriale hulpverlening. Het totale hulpaanbod is meer gedifferentieerd, maar in hoeverre dit is afgestemd op de hulpvragen, kan pas in de loop van de jaren negentig worden nagegaan wanneer de definitieve invoering van een functionele verstrekkingensystematiek haar beslag krijgt, de effecten van de substitutieregeling zijn bestudeerd en de voor- en nadelen van de cliëntgebonden budgetfinanciering zijn geanalyseerd.

\subsection{Besluit: Ontwikkeling van gezinsbegeleiding}

Tijdens de Conferentie Gezinsbegeleiding in 1977 maakten ouders van een kind met een verstandelijke handicap duidelijk dat zij zich soms gedwongen voelden dit kind eerder dan zij voor henzelf, de andere kinderen in het gezin en het gehandicapte kind wenselijk of noodzakelijk achtten, uit huis te plaatsen. Zij gaven aan om welke redenen de toenmalige zwakzinnigenzorg hen belemmerde het gehandicapte kind in het gezin groot te brengen: (a) Aangezien het hulpaanbod was afgestemd op de door de AWBZ erkende voorzieningen, kwamen ouders niet in aanmerking voor alle onderdelen van de zorg die in principe beschikbaar waren; (b) ouders konden door de geringe samenhang in het hulpaanbod en de geringe samenwerking tussen hulpverleners, moeilijk hun weg vinden naar en in de zwakzinnigenzorg; (c) ouders hadden het idee door hulpverleners weinig serieus genomen te worden; en (d) vormen van hulp die specifiek op ondersteuning van het gezin gericht waren, ontbraken grotendeels.

De landelijke overheid nam zich de wensen van de ouders ter harte. Begin jaren tachtig formuleerde zij als uitgangspunt voor haar beleid dat dit erop gericht moest zijn de (verstandelijk) gehandicapte als volwaardig lid van de samenleving te beschouwen. Mede als gevolg van de veranderde hulpwragen van de ouders werd "gezinsbegeleiding" én van de centrale thema's in het overheidsbeleid. Zoals 
aangekondigd in achtereenvolgende nota's, is een belangrijk deel van de belemmeringen voor ouders om hun gehandicapte kind thuis op te voeden, in de loop van de jaren tachtig opgeheven. Wanneer in de negentiger jaren de herstructurering van de gezondheidszorg in haar geheel is voltooid, zouden ouders vrij moeten kunnen kiezen tussen het kind thuis te houden of het in een woonvoorziening te plaatsen.

De organisatie van de zorgverlening die langzaam maar zeker vorm krijgt en de ontwikkeling van hulpvormen ter ondersteuning van het gezin kunnen afstel van een definitieve uithuisplaatsing niet voorkomen. Ook verstandelijk gehandicapten verlaten vroeger of later hun ouderlijk huis om elders te gaan wonen. De stelling dat de vernieuwde zorg- en dienstverlening tegen lagere kosten voor grote groepen mensen tot uitstel van uithuisplaatsing zal leiden, moet eveneens nog bewezen worden. Naar onze indruk leiden de vernieuwingen er vooral toe dat het leven tot aan een definitieve uithuisplaatsing voor het hele gezin minder belastend en dus plezieriger wordt. 


\section{Hulpvormen ter begeleiding van het gezin}

Vanaf de jaren zeventig zijn drie nieuwe vormen van gezinsbegeleiding ontstaan: Praktisch Pedagogische Gezinsbegeleiding, Praktische Thuishulp en Weekendopvang. Deze hulpvormen zijn gericht zijn op de bevordering van het evenwicht tussen de draagkracht van ouders en de draaglast die het leven met een verstandelijk gehandicapt kind kan meebrengen.

In $5.1 \mathrm{t} / \mathrm{m} 5.3$ worden de organisatie, het doel, de doelgroepen en de werkwijze van deze hulpwormen worden besproken. Op grond daarvan worden hypotheses opgesteld ten aanzien van de kenmerken van de gezinnen die deze hulp aanvragen en ten aanzien van de effecten ervan op de stress van ouders en de mogelijke determinanten ervan. Tevens worden de afdelingen en projecten die hun medewerking aan het onderhavige onderzoek hebben verleend, kort gepresenteerd.

\subsection{Praktisch Pedagogische Gezinsbegeleiding}

\section{Organisatie}

Praktisch Pedagogische Gezinsbegeleiding (PPG) is een aparte afdeling binnen de Sociaal Pedagogische Dienst (SPD). Het aantal functionarissen van PPG-afdelingen kan varièren van eén tot meer dan tien, met een gemiddelde van vier tot zes personen (Van Linge \& Janssen, 1987). De personele samenstelling kent verschillende varianten. Een PPG-team bestaat altijd uit een coördinator algemene zaken die belast is met de organisatorische gang van zaken, een cobrrdinator inhoudelijke zaken, veelal een orthopedagoog, die belast is met uitvoerende en ondersteunende pedagogische taken en eén of meer pedagogisch werkenden die het werk in de gezinnen uitvoeren. Soms worden de twee eerste functies door één persoon vervuld. Soms maakt een maatschappelijk werkende deel uit van het PPG-team (SOMMA, 1986). 


\section{Doelstelling en doelgroepen}

Praktisch Pedagogische Gezinsbegeleiding richt zich op gezinnen met een kind dat een verstandelijke handicap heeft of in zijn of haar ontwikkeling bedreigt lijkt te worden en op gezinnen met (een) zwakbegaafd(e) ouder(s). PPG kan worden aangevraagd wanneer ouders de omgang met en de opvoeding van het gehandicapte kind als moeilijk ervaren. In uitzonderingsgevallen en in overleg met andere regionale hulpverleners kan PPG ook verleend worden aan gezinnen met een normaal begaafd kind, bijvoorbeeld als er sprake is van (een vermoeden van) autisme. PPG tracht de draagkracht van ouders te vergroten door hun opvoedingscompetentie en probleemoplossend vermogen te doen toenemen. De uiteindelijke doelstelling van Praktisch Pedagogische Gezinsbegeleiding is het gezin zodanig te begeleiden dat het van mening is de opvoeding van het kind weer op eigen kracht aan te kunnen.

Een groot gedeelte van de hulpvragen heeft betrekking op de gedragsproblematiek van het gehandicapte kind. Ouders willen hierbij weten hoe zij het best kurnen omgaan met gedragsproblemen als ongehoorzaamheid, dwingend gedrag, driftbuien, slaap- en eetproblemen. Gedragsproblemen liggen in toenemende mate ten grondslag aan de aanvragen yoor PPG (SOMMA, 1990a).

Een tweede cluster van hulpvragen betreft de stimulering van de ontwikkeling van het kind. Het gaat soms om de totale verstandelijke en lichamelijke ontwikkeling wan met name jonge kinderen, soms om het stimuleren van specifieke aspecten van de ontwikkeling, zoals de taal, het spel, de zelfredzaamheid en de zindelijkheid. Een derde cluster van hulpvragen heeft betrekking op het aanleren van vaardigheden die verstandelijk gehandicapten in staat moeten stellen sociale contacten te leggen en te onderhouden, vooral met leeftijdgenoten buiten het gezin (SOMMA, 1990a; VonkDekkers \& Verhoeven, 1989).

Praktisch Pedagogische Gezinsbegeleiding wordt pas toegekend als niet (meer) volstaan kan worden met een eenvoudig advies (SOMMA, 1990b). Dit betekent dat ouders die PPG krijgen toegewezen, meestal al op verschillende manieren hebben geprobeerd hun opvoedingsproblemen op te lossen, uiteindelijk resultaat. Veel ouders zijn hierdoor onzeker geworden en hebben weinig vertrouwen (meer) in het eigen handelen (Van Linge \& Janssen, 1985). Dit heeft het pedagogische klimaat vaak verder doen verslechteren en aanleiding gegeven tot een verergering van de opvoedlingsproblematiek. In veel gezinnen is dan ook sprake van meerdere opvoedingsproblemen die elkaar gedeeltelijk overlappen (Vonk-Dekkers \& Verhoeven, 1989).

In een aantal gezinnen zijn, naast de pedagogische problemen waarop PPG zich richt, andere problemen aanwezig, bijvoorbeeld moeilijkheden met het voeren van een huishouding, psychische, somatische, relationele of financiele problemen. In de zogeheten multi-problemgezinnen, die veel van deze complexe problemen hebben, wordt PPG vaak beelindigd zonder dat alle pedagogische hulpvragen volledig zijn beantwoord (Janssen \& Meester, 1985; Linssen-Musters, 1988). Dit komt doordat ouders in deze gezinnen vaak weinig energie, emotionele ruimte en tijd hebben om 
zich in te zetten voor de oplossing van hun opvoedingsproblemen, De aanwezigheid van andere problemen is niet per se een contra-indicatie voor Praktisch Pedagogische Gezinsbegeleiding, maar indien ouders niet gemotiveerd of te motiveren zijn om actief mee te werken aan het voor de oplossing van hun opvoedingsproblemen benodigde veranderingsproces, is dat wel een contra-indicatie (SOMMA, 1990b; Verheijen, 1984).

De motivatie van althans eén van de ouders heeft te maken met het begrip "gezinsbegeleiding". Dit verwijst, behalve naar de plaats waar de hulp gegeven wordt, naar het feit dat PPG ouders serieus neemt en respecteert in hun ouderlijke verantwoordelijkheid. De pedagogisch werkenden nemen geen taken van ouders over, maar werken met het gexin samen om de meest geschikte antwoorden op de opvoedingsvragen te vinden. Als ouders niet kunnen of willen meewerken of als cén van hen tegenwerkt, is er onvoldoende perspectief op verbetering van de opvoedingsrelatie en heeft PPG weinig kans van slagen.

De hulpverleningsmethode is praktisch van aard. Kenmerkend is het handelen. Al doende, met spel of andere activiteiten, en al pratende probeert men te ontdekken wat er precies aan de hand is. Door ondervinding wordt getracht de beste oplossingen en antwoorden voor de problemen en vragen te vinden.

\section{Werkwijze}

Praktisch Pedagogische Gezinsbegeleiding kent een aanmeldings-, een werk- en een afsluitingsfase. Tot op heden vindt de aanmelding meestal direct bij de afdeling PPG plaats. Nu de regionalisatie steeds meer vorm krijgt, zal PPG in toenemende mate beschikbaar komen via regionale indicatie- en zorgtoewijzingscommissies. De aanmelding kan plaatsvinden door de ouders zelf, hun maatschappelijk werkende van de SPD en instanties of personen in de regio. Aanmelding door anderen dan de ouders zelf gebeurt alleen met hun toestemming: zij zijn nadrukkelijk zelf verantwoordelijk voor de opvoeding en voor de keuze daarbij al dan niet hulp te vragen (Landelijke Commissie Gezinsbegeleiding, 1982; Verheijen, 1984).

Tijdens een intakebespreking verzamelt de afdeling PPG informatie over de woonplaats van het gezin (binnen het werkgebied van de betreffende SPD), de handicap van het kind (bijkomende handicaps vormen geen contra-indicatie) of de ouders (zwakbegaafdheid), de leeftijd van het kind (er wordt geen leeftijdsgrens gehanteerd), de verblijfplaats van het kind (uit of thuis wonend), de gezinssituatie (gezinssamenstelling, aanwezigheid van meerdere problemen, motivatie) en de hulpvraag (SOMMA, 1990b). Wordt besloten PPG te verlenen, dan introduceert de orthopedagoog, soms samen met de maatschappelijk werkende, een pedagogisch werkende in het gezin.

In de werkfase besteedt de pedagogisch werkende de eerste vier tot zeven huisbezoeken aan participerende observatie en aan gesprekken met de ouders om een relatie met hen op te bouwen en om zich te oriènteren op de pedagogische situatie. Aan het eind van deze observatieperiode stelt de pedagogisch werkende in overleg 
met de orthopedagoog een werkplan op met een gedetailleerde probleemomschrijving, de concrete doelstellingen van PPG, de methode die men gaat volgen om deze te bereiken en de vermoedelijke duur van de hulpverlening. De pedagogisch werkende en de orthopedagoog bespreken het werkplan met de ouders (SOMMA, 1986). Aan de hand hiervan trachten de pedagogisch werkende en de gezinsleden in de volgende zes tot tien huisbezoeken, de zogeheten veranderingsfase (OosterhofBeugelink, 1985), de problemen systematisch op te llossen of hanteerbaar te maken.

De pedlagogisch werkende schrijft van elk huisbezoek een verslag, dat hij of zij met de orthopedagoog bespreekt. De huisbezoeken duren gemiddeld anderhalf uur en vinden meestal eens per week plaats, bij voorkeur op de momenten dat het probleem optreedt.

Na deze reeks huisbezoeken kan, bijvoorbeeld bij complexe problematiek, een verlenging van de werkfase noodzakelijk blijken, Wanneer de doelen bereikt zijn, de ouders zich in staat voelen alleen verder te gaan of PPG niet aanslaat, wordt de hulp afgeslloten door de frequentie van de huisbezoeken te verminderen. In deze afsluitingsfase tracht men het bereikte te bestendigen. PPG wordt afgerond met een eindverslag waarin alle fasen van de hulpverlening aan de orde komen. Aan de hand van dit verslag vindt een eindgesprek met de ouders plaats, waarbij naast de pedagogisch werkende meestal de orthopedagoog en soms de maatschappelijk werkende aanwezig zijn. PPG duurt gemiddeld een half jaar tot een jaar.

\section{Praktisch Pedagogische Gezinsbegeleiding in het onderzoek}

Aan het onderhavige evaluatie-onderzoek werken vier afdelingen PPG mee, alle werkzaam in verschillende regio's van Noord-Brabant. De beschrijvingen van deze afdelingen zijn gebaseerd op jaarverslagen en procedurebeschrijvingen.

(1) De afdeling PPG van de Sociaal Pedagogische Dienst Eindhoven en De Kempen. De afdeling is in 1984 opgericht en is samengesteld uit een coördinator algemene zaken, een orthopedagoog en zeven pedagogisch werkenden. Per jaar wordt aan ongeveer 40 gezinnen hulp geboden.

(2) De afdeling PPG van de Othmanus Stichting te Helmond, een geïntegreerde dienst waaronder ook de Sociaal Pedagogische Dienst ressorteert. Het PPG-team, opgericht in 1985, bestaat uit een orthopedagoog die de inhoudelijke en de algemene zaken coordineert, een maatschappelijk werkende en twee pedagogisch werkenden. Jaarlijks worden ongeveer 10 gezinnen in begeleiding genomen.

(3) De afdeling PPG van de Stichting Regionale Sociaal Pedagogische Dienst voor Noordoost Noord-Brabant en Noordelijk Noord-Limburg te Uden. Deze stichting is in 1988 ontstaan als gevolg van de fusie van de Sociaal Pedagogische Diensten te Oss, Veghel en Boxmeer. In deze Sociaal Pedagogische Diensten is PPG op verschillende tijdstippen ontstaan: in Veghel in 1979, in Oss in 1984 en in Boxmeer in 1985 (Vonk-Dekkers \& Verhoeven, 1989). Het PPG-team in Uden bestaat uit een coördinator algemene zaken, een orthopedagoog, én maatschappelijk werkende 
van elke sub-regio en zes pedagogisch werkenden. Jaarlijks worden ongeveer 30 nieuwe gezinnen in begeleiding genomen.

(4) De afdeling PPG van het Regionaal Sociaal Pedagogisch Centrum "IgnacioStichting" te Rosmalen. De afdeling is opgericht in 1984 en bestaat uit een algemeen coördinator tevens maatschappelijk werkende, een orthopedagoog en twee pedagogisch werkenden. Jaarlijks worden ongeveer 20 gezinnen in begeleiding genomen.

Landelijk bestaan grote overeenkomsten tussen PPG-afdelingen in de inhoud, werkwijze, indicatiecriteria en organisatie van de hulp. Aangezien er geen redenen zijn om aan te nemen dat de bij het onderzoek betrokken teams hiervan in belangrijke mate afwijken, worden deze vier afdelingen beschouwd als exemplarisch voor de hulpvorm Praktisch Pedagogische Gezinsbegeleiding.

\section{Hypotheses}

Op grond van de beschrijving van Praktisch Pedagogische Gezinsbegeleiding zijn hypotheses opgesteld ten aanzien van de kenmerken van de gezinnen die deze hulp aanvragen. Deze hypotheses beginnen met het cijfer 1:

In gezinnen die Praktisch Pedagogische Gezinsbegeleiding aanwragen:

Hypothese 1-1: heeft het verstandelijk gehandicapte kind meer stresserende kenmerken, met name meer gedragsprablemen en een geringere sociale redzaamheid;

Hypothese 1-2: hebben de ouders minder zelfwaardering;

Hypothese 1-3: ervaren de ouders meer concrete problemen; en

Hypothese 1-4: voelen de ouders zich in psychosomatisch opzicht slechter, dan in gezinnen die geen Praktisch Pedagogische Gezinsbegeleiding aanvragen.

De hypotheses ten aanzien van de effecten van PPG beginnen met een $2 . \mathrm{Zij}$ luiden: In gezinnen die Praktisch Pedagogische Gezinsbegeleiding hebben gehad:

Hypothese 2-1: heeft zich een grotere afname in de stresserende kenmerken van het verstandelijk gehandicapte kind voorgedaan, met name wat de gedragsproblematiek en sociale redzaamheid betreft;

Hypothese 2-2: hebben de ouders meer zelfwaardering gekregen;

Hypothese 2-3: heeft een grotere reductie in de concrete problemen van de ouders plaatsgehad; en

Hypothese 2-4: heeft een grotere toename in het psychosomatisch welbevinden van de ouders plaatsgehad, dan in gezinnen die geen Praktisch Pedagogische Gezinsbegeleiding hebben gehad.

\subsection{Praktische Thuishulp}

\section{Organisatie}

In 1990 waren er in Nederland 25 tot 30 centrales voor Praktische Thuishulp of Oppashulp (bron: Stichting Dienstverleners Gehandicapten, Utrecht). De meeste daarvan zijn opgericht door ouders of andere gezinsleden van mensen met een (verstandelijke) handicap. De uiteindelijke verantwoordelijkheid voor de hulp ligt meestal bij de plaatselijke oudervereniging(en), al dan niet in samenwerking met 
regionale instanties die zich bezighouden met de hulpverlening aan gezinnen met een (verstandelijk) gehandicapte huisgenoot.

Binnen de Praktische Thuishulpcentrales zijn voomamelijk vrijwilligers werkzaam. De centralles bestaan meestal uit een coördinator, die soms voor een gedeelte van de tijd betaald wordt, eén of meer contactpersonen en een aantal vrijwilligers. De taken van de coördinator betreffen de organisatie en de $\mathrm{kw}$ waliteitsbewaking van het project, waaronder de verstrekking van informatie en voorlichting, de werving van vrijwilligers en het onderhouden van contacten met andere hulpverlenende instanties.

De contactpersonen, zelf meestal ouders of familielleden van een (verstandelijk) gehandicapte, wonen bij voorkeur in hetzelfde stadsdeel of dorp als de gezinnen. Zij kunnen hen wijzen op het bestaan van Praktische Thuishulp, zoeken na de aanmelding een passende vrijwilliger en introduceren deze in het gezin. Nadien blijven zij contact houden om op de hoogte te blijven van het verloop van de thuishulp.

De vrijwilligers voeren de hulp uit. Voor ieder gezin wordt gezocht naar een vaste vrijwilliger van minimaal 16 jaar die zich betrokken kan voelen bij gezinnen met een gehandicapt familielid. Ervaring of een opleiding in de zorg zijn meestal geen voorwaarden voor het werk (Nass, 1989).

\section{Doelstelling en doelgroepen}

De Praktische Thuishulp- en Oppascentrales beogen aan gezinnen met een (verstandelijk) gehandicapte huisgenoot hulp te bieden bij praktische problemen, voor zover het gezin zelf en andere hulpverlenende instanties daarin niet voorzien. Het uiteindelijke doel is de gezinnen tijdelijk te ontlasten van de extra druk(te) die een gehandicapte huisgenoot met zich brengt.

Sommige projecten bieden praktische hulp aan alle gezinnen met een gehandicapte huisgenoot, ongeacht de aard van de handicap. Deze centrales zijn van mening dat een lage drempel het aanvragen van hulp eenvoudiger maakt. Andere centrales bieden alleen hulp aan gezinnen met een verstandelijk gehandicapte huisgenoot, omdat dit een specifieke deskundigheid en mentaliteit van de vrijwilligers zou vragen. Bij deze laatste projecten vormt een bijkomende lichamelijke handicap overigens geen contra-indicatie. De (verstandelijke) handicap, de regionale afbakening wan het betreffende project en de hulpvraag zijn de enige intake- en indicatiecriteria.

Praktische Thuishulp is binnen haar doelstellingen flexibel in de aard van de hulpverlening. De projecten kunnen uiteenlopende soorten hulp bieden, zoals oppas in of buiten het gezin, gedurende enkele uren, eén of meer dagen, overdag of 's avonds, bezigheidsbegeleiding of speelhulp en hulp bij de verzorging van het (verstandelijk) gehandicapte kind. Ouders kunnen én of meer soorten hulp aanvragen. De hulp kan in de loop der tijd andere vormen gaan bestrijken. De wensen van het gezin staan ook centraal in de frequentie van de hulpverlening. Sommige gezinnen vragen wekelijks hulp, andere enkele malen per jaar. De hulp kan na verloop van tijd meer of minder frequent worden. 


\section{Werkwijze}

Gezinnen met praktische hulpvragen kunnen zich direct bij een coördinator of contactpersoon aanmelden of, met hun toestemming, indirect via een andere hulpverIener. Als de hulpvraag niet binnen de doelstellingen van de centrale ligt, volgt een verwijzing naar een meer geeigende instantie. Kan men wel aan de hulpvraag voldoen en heeft de centrale een geschikte vrijwilliger gevonden, dan kan de hulp zolang duren tot het gezin er geen behoefte meer aan heeft. Andere redenen om Praktische Thuishulp te beëindigen, kunnen liggen in ontevredenheid met de hulp, een verhuizing van het gezin, een definitieve opname van de (verstandelijk) gehandicapte in een dag- en nachtvoorziening of zijn of haar overlijden. In sommige gezinnen liggen de oorzaken van de beeindiging van de hulp bij de vrijwilliger, zoals een verhuizing, de aanvaarding van een betaalde baan of uitbreiding van het eigen gezin. Men tracht dan een andere vrijwilliger te vinden.

\section{Praktische Thuishulp in het onderzoek}

Aan het onderhavige onderzoek werken zes Praktische Thuishulp- en Oppascentrales mee. De beschrijvingen van deze centrales zijn gebaseerd op jaarverslagen en gesprekken met betrokkenen.

(1) De Praktische Thuishulpcentrale Eindhoven en ornstreken. Deze centrale is in 1979 opgericht op initiatief van de ouderverenigingen. De centrale is een samenwerkingsproject van de Vereniging van Ouders van Geestelijk Gehandicapten, afdelingen Eindhoven, de Kempen, Veldhoven en Valkenswaard, de afdeling Eindhoven van de oudervereniging Philadelphia en de Sociaal Pedagogische Dienst Eindhoven en De Kempen. Voor de uitwoering van de hulp is een regionale werkgroep verantwoordelijk, waarin vertegenwoordigers van de ouderverenigingen, de contactpersonen en een maatschappelijk werkende van de SPD zitting hebben. De centrale verleent oppas, speelhulp en hulp bij de verzorging aan gezinnen met een verstandelijk gehandicapte huisgenoot. De centrale beschikt over een coördinator die in deeltijd betaald wordt, ongeveer 20 contactpersonen en 80 vrijwilligers, die jaarlijks hulp verlenen aan 80 tot 90 gezinnen.

(2) Praktische Thuishulp in de regio Helmond. Dit project, in 1986 gestart, is een samenwerking van de Vereniging van Ouders van Geestelijk Gehandicapten, afdelingen Gemert, Helmond, Asten/Someren en Deume, de Othmarus Stichting te Helmond (geintegreerde Sociaal Pedagogische Dienst), de Stichting 't Rijtven te Deume (intramurale voorziening) en de St. Hubertusschool voor ZMLK-onderwijs te Helmond. De eindverantwoordelijkheid is ondergebracht bij de Begeleidingscommissie Regionaal Steunpunt Helmond, die bestaat uit ouders en beroepskrachten van de genoemde instanties en zorg draagt voor een goede afstemming van de hulpverlening in de regio Helmond. Voor de uitvoering van de hulp is een werkgroep verantwoordelijk waarin de ouderverenigingen, het maatschappelijk werk en de vrijwilligers vertegenwoordigd zijn. De hulp, voornamelijk oppas en bezigheidsbegeleiding, is alleen beschikbaar voor gezinnen met een verstandelijk gehandicapte huisgenoot. Met 10 tot 15 contactpersonen en 20 to 25 vrijwilligers biedt het project jaarlijks hulp aan 20 tot 30 gezinnen. 
(3) De Praktische Thuishulpcentrale in de regio's "s-Hertogenbosch en Boxtel. Deze centrale is in 1988 opgericht, nadat een oppascentrale die in 1985 was opgericht door de Vereniging van Ouders van Geestelijk Gehandicapten afdeling 's-Hertogenbosch, niet optimal meer bleek te functioneren. De nieuwe centrale is een samenwerkingsproject van het Regionaal Sociaal Pedagogisch Centrum "Ignacio-Stichting" te Rosmalen waar tevens de eindverantwoordelijkheid berust, de Sociaal Pedagogisehe Zorg in Boxtel en de Stichting Gespecialiseerd Jeugd- en Volwassenenwerk. Een werkgroep waarin vertegenwoordigers van deze instellingen en de contactpersonen zitting hebben, heeft als taken informatie en voorlichting te verstrekken, wrijwilligers te werven, contacten te onderhouden met de gezinsverzorging, het kruiswerk en de ouderverenigingen en het aanbod op de hulpvragen af te stemmen. Met een onbetaalde coördinator, twee contactpersonen en ongeveer 20 vrijwilligers biedt deze centrale jaarlijks oppas en speelhulp aan 20 tot 30 gezinnen met een verstandelijk gehandicapt kind.

(4) De Oppascentrale Tilburg en omstreken. Deze centrale is in 1979 opgericht op initiatief van de Vrijwilligerscentrale, die verantwoordelijk is voor alle vrijwilligerswerk op het gebied van thuiszorg in deze stad. De Oppascentrale is een zelfstandige werkgroep binnen de Vrijwilligerscentrale. Verantwoordelijk voor de Oppascentrale is een werkgroep van vijf leden, onder wie een vertegenwoordiger van de Vrijwilligerscentrale en een vertegenwoordiger van de afdeling Tilburg van de Vereniging van Ouders van Geestelijk Gehandicapten. De Oppascentrale biedt, met één onbetaalde coördinator/contactpersoon en ongeveer tien vrijwilligers, alleen oppas aan de vijf tot tièn gezinnen die zich jaarlijks nieuw aanmelden. De hulp is beschikbaar voor gezinnen met een lichamelijk, verstandelijk of meervoudig gehandicapte huisgenoot.

(5) De Stichting Oppascentrale Midden-Limburg. Deze centrale is in 1980 opgericht op initiatief van de Stichting Pedagogisch Sociaal Werk Midden-Limburg en de Vereniging van Ouders van Geestelijk Gehandicapten, afdeling Roermond. De oppascentrale heeft een bestuur waarin ouders, vrijwilligers en het maatschappelijk werk vertegenwoordigd zijn. De onbetaalde coördinator bemiddelt samen met drie bestuursleden/contactpersonen tussen de gezinnen en de ongeveer 70 vrijwilligers op wie de centrale een beroep kan doen. Jaarlijks wordt voor 50 tot 60 gezinnen bemiddeld: De hulp bestaat wit oppas in de ruimste zin van het woord: passief en actief, binnen het gezin en in gastgezinnen. Indien mogelijk worden ook vragen om hulp bij thuis wonende demente bejaarden en terminale patiënten gehonoreerd. Gezinnen met een lichamelijk, verstandelijk of meervoudig gehandicapte huisgenoot komen in aanmerking voor de hulp.

(6) De Oppas-Thuishulpcentrale Westelijke Mijnstreek. Deze centrale is in 1987 nieuw leven ingeblazen nadat de oorspronkelijke initiatiefnemers zich hadden teruggetrokken. De eindverantwoordelijkheid voor de huidige centrale ligt bij de Sociaal Pedagogische Dienst te Sittard. Een stuurgroep waarin de in deeltijd betaalde coördinator/contactpersoon, twee vrijwilligers en een moeder zitting hebben, verschaft informatie en voorlichting, werft vrijwilligers, stemt het hulpaanbod af op 
de hulpvragen, bewaakt de kwaliteit van de hulpwerlening en organiseert speciale activiteiten, zoals een spelletjes-middag. De 25 tot 30 vrijwilligers bieden jaarlijks hulp aan evenveel gezinnen met een verstandelijk, lichamelijk of meervoudig gehandicapt kind. De hulp bestaat wit oppas, bezigheidsbegeleiding en hulp bij de verzorging van het gehandicapte kind.

\section{Hypotheses}

Praktische Thuishulp kan uiteenlopende vragen om taakverlichting op praktisch gebied beantwoorden. Er zijn nauwelijks indicatiecriteria om de grenzen van de hulp aan te geven. Dit betekent dat ten aanzien van de kenmerken van de hulpvragers éen hypothese is opgesteld. Deze hypothese begint met het cijfer 3:

Hypothese 3-1: In gezinnen die Praktische Thuishulp aanvragen, ervaren de ouders meer praktische druk dan in gezinnen die geen Praktische Thuishulp aanvragen.

Ten aanzien van de effecten van de hulp is eveneens een hypothese opgesteld. Deze begint een 4:

Hypothese 4-1: In gezinnen die Praktische Thuishulp hebben, heeft een grotere reductie in de praktische druk van de ouders plaatsgehad dan in gezinnen die geen Praktische Thuishulp hebben.

\subsection{Weekendopvang}

Aan het onderzoek werken drie projecten Weekendopvang mee, die van vrijdag- tot zondagavond thuis wonende verstandelijk gehandicapten opvangen ter ontlasting van de overige gezinsleden. Aangezien Weekendopvang slechts op enkele plaatsen in Nederland is opgezet en uiteenlopende doelstellingen kan hebben (zie 4.3), hebben de beschrijvingen en de hypotheses alleen op deze projecten betrekking. De beschrijvingen zijn gebaseerd op jaarverslagen en procedurebeschrijvingen.

\section{Organisatie}

(1) In de regio Zuidoost-Brabant wordt vanaf januari 1984 onder auspiciën van de Vereniging Regionaal Overlegorgaan Zorg voor Geestelijk Gehandicapten (ROZ) Weekendopvang georganiseerd. De Severinusstichting te Veldhoven, eén van de intramurale voorzieningen in de regio, en de Sociaal Pedagogische Diensten Eindhoven en De Kempen, Helmond, Boxtel en Uden werken voor de uitvoering van de Weekendopvang samen. De ambulante diensten coördineren de aanmeldingen, verstrekken informatie en voorlichting en begeleiden de gezinnen. De Severinusstichting is verantwoordelijk voor het beheer en de uitwoering van het project. De Weekendopvang wordt begeleid door betaalle Z-verpleegkundigen en gerealiseerd in een accommodatie op het terrein van de Severinusstichting, de zogeheten vakantieboerderij. Deze staat 40 weekends per jaar open voor het project en biedt per weekend plaats aan 8 kinderen en in de zomermaanden, wanneer er activiteiten buiten kunnen plaatsvinden, aan maximaal 10 kinderen. In totaal vindt cen vaste groep van 50 kinderen geregeld een plaats in deze Weekendopvang. 
(2) In de regio Noordoost Noord-Brabant organiseert het Regionaal Sociaal Pedagogisch Centrum "Ignacio-Stichting" te Rosmalen vanaf september 1987 Weekendopvang onder verantwoordelijkheid van het bestuur van het deze SPD. Het kinderdaguerblijf "De Elzengaard" in "s Hertogenbosch is jaarlijks 10 weekends open gesteld voor maximaal 12 thuis wonende kinderen met een verstandelijke handicap. In totaal bereikt deze opvang een groep van 24 gezinnen. De begeleiding is in handen van vrijwilligers, deels $\mathrm{Z}$-verpleegkundigen en mensen met een andere opleiding in de zorg voor verstandelijk gehandicapten, deels leerlingen van middelbare beroepsopleidingen, zoals het MDGO.

(3) In de regio Midden-Brabant wordt vanaf oktober 1989 Weekendopvang gerealiseerd in het kinderdagverblijf "Het Zonnelicht" in Tilburg. Dit project wordt gecoördineerd door een werkgroep bestaande uit maatschappelijk werkenden van de betrokken Sociaal Pedagogische Diensten, te weten Tilburg, Waalwijk en Wijk en Aalburg, de coördinator van het ROZ-bureau Midden-Brabant en de directrice en een spelbegeleidster van het kinderdagverblijf. Het dagverblijf staat 10 weekends per jaar open voor de opvang van thuis wonende verstandelijk gehandicapten. Er is plaats voor 15 kinderen die men dag en nacht kan opvangen; daamaast kunnen 5 kinderen overdag van de opvang gebruik maken. In totaal kan men een groep van 40 kinderen geregeld cen weekend of een dag(deel) opvang aanbieden. De begeleiding vindt door vrijwilligers plaats, voor een gedeelte gediplomeerde Z-verpleegkundigen, voor het overige leerlingen van middelbare beroepsopleidingen.

\section{Doelstelling en doelgroepen}

De drie projecten Weekendopvang beogen het gezin tijdelijk te ontlasten van de (ver)zorg(ing) van het verstandelijk gehandicapte kind door dit kind gedurende enkele weekends per jaar buiten het gezin op te vangen. Gezien deze op ondersteuning van het gezin gerichte doelstelling bieden de projecten geen onderzoeks- of behandelingsprogramma ten behoeve van het kind aan.

Hoewell alle ouders van een thuis verblijvend verstandelijk gehandicapt kind die woonachtig zijn in het verzorgingsgebied van de respectievelijke regionale overlegorganen in aanmerking komen voor de hulp, hebben de projecten wel enige beperkingen aangebracht in hun doelgroepen. Zo is de maximum leeftijd van de deelnemers in Zuidoost-Brabant 17 jaar, in verband met de te gebruiken accommodatie en met het feit dat kinderen van 18 jaar en ouder een eigen bijdrage uit hun AAWuitkering moeten leveren. Bij de twee andere projecten komen kinderen niet meer in aanmerking voor de opvang wanneer zij hun school of kinderdagverblijf verlaten en naar een dagverblijf voor ouderen of een sociale werkplaats gaan (20 jaar). Geen van de projecten stelt een minimum leeftijdsgrens.

De projecten stellen geen expliciete grenzen aan het verstandelijk nivo van functioneren van de deelnemers. In de praktijk blijken de deelnemers echter matig, emstig of zeer ernstig verstandelijk gehandicapt te zijn. In de regio Noordoost NoordBrabant is in eerste instantie ook getracht leerlingen van scholen voor moeilijk lerende kinderen (MLK) bij de opvang te betrekken. Uit de evaluatie van enkele 
proefweekends in 1986 bleek het verschil tussen deze licht verstandelijk gehandicapte kinderen en de overige deelnemers zowel voor de kinderen en hun ouders als voor de leiding echter zo groot te zijn, dat geadviseerd is een aparte Weekendopvang voor licht verstandelijk gehandicapten op te zetten.

De Weekendopvang in Zuidoost-Brabant neemt voorts geen kinderen meer op die met een hoge urgentie op de Centrale Wachtlijst Zwakzinnigen (CWZ) staan. Uit een evaluatie kwam naar voren dat de opvang aan deze kinderen, voor wie een definitieve uithuisplaatsing dringend gewenst is, niet die intensieve begeleiding kan bieden die voor hen en hun ouders noodzakelijk is (Van Berkum, 1986). Deze kinderen worden sindsdien verwezen naar de mogelijkheden voor Weekendopvang in de woongroepen van de intramurale voorzieningen. De twee andere projecten sluiten kinderen die urgent uit huis geplaatst moeten worden, niet van deelname uit:

De drie projecten brengen tenslotte geen expliciete begrenzingen aan in de lichamelijke gezondheid van de kinderen. De accommodaties van de projecten staan echter gelijktijdige opname van meerdere niet-ambulante kinderen niet toe. De verzorging van lichamelijk zwakke of meervoudig gehandicapte kinderen vereist bovendien extra tijd en specifieke deskundigheid. Bij het project in Zuidoost-Brabant is deze deskundigheid gegarandeerd vanwege de opleiding en ervaring van de begeleidende $Z$-verpleegkundigen. In Noordoost Noord-Brabant heeft men in de loop der jaren meer Z-verpleegkundigen kunnen inzetten, hetgeen nodig was vanwege een toenemend aantal meervoudig gehandicapte deelnemers. Aangezien men bij het jongste project, dat in Midden-Brabant, nog op zoek is naar meer specifieke deskundigheid, is men daar terughoudend in het opnemen van meervoudig gehandicapte kinderen.

Ouders hebben verschillende redenen om zich aan te melden voor Weekendopvang (Van Berkum, Bremer, Kok \& Wijffels, 1988). Eén categorie van redenen heeft betrekking op de ouders zelf en de andere kinderen in het gezin, zoals zelf tot rust komen, aandacht geven aan de partner en de andere kinderen, activiteiten ondernemen die met het gehandicapte kind erbij moeilijk te realiseren zijn en ontlast zijn van de voortdurende zorg voor het kind. Een tweede categorie van redenen ligt bij het verstandelijk gehandicapte kind: bevordering van zijn of haar zelfstandigheid, doorbreking van een (dreigende) sociale isolatie vanwege de afwezigheid van speelkameraden thuis en het aanbieden van een logeermogelijkheid die de andere kinderen in het gezin vaak vanzelfsprekend in de familie- of vriendenkring hebben. Soms noemen ouders nog een derde reden voor Weekendopvang, namelijk dat zij zelf, hun gehandicapte kind en hun andere kinderen langzaam willen wennen aan het idee dat het gehandicapte kind niet altijd thuis zal blijven wonen.

\section{Werkwijze}

Wanneer ouders behoefte hebben aan opvang van het gehandicapte kind tijdens de weekends, kunnen zij zich voor de projecten aanmelden bij hun Sociaal Pedagogische Dienst. Naarmate de regionalisatie meer vorm krijgt, zal deze hulp via regionale indicatie - en zorgtoewijzingscommissies beschikbaar komen. Aangezien de vraag naar Weekendopvang het aanbod van de projecten overstijgt, verwijst men het 
gezin soms naar andere opvangmogelijkheden. Soms plaatst men het op een wachtlijst totdat een ander gezin afvalt of laat men het nieuw aangemelde gezin in een lage frequentie van de opvang gebruik maken.

De ouders worden tijdig schriftelijk op de hoogte gesteld wan de data waarop hun kind welkom is in de vakantieboerderij respectievelijk het kinderdagverblijf. Men tracht bij de planning tegemoet te komen aan de wensen van de ouders ten aanzien van de data en de frequentie van deelname. Aangezien dit laatste niet altijd mogelijk is, bepaalt de inschatting van de relatieve bellasting van het gezin de frequentie waarmee het kind in aanmerking komt voor de Weekendopvang.

De ouders dragen zelf zorg voor het vervoer van hun kind van en naar de opvang. De activiteiten die men daar gedurende de weekends onderneemt, zijn recreatief van aard. $Z_{i j}$ wijken nauwielijks af van de activiteiten die gezinnen zelf is weekends ondememen: spelletjes doen, wandelingen maken, boodschappen doen, tv of video kijken, naar muziek luisteren, zwemmen, en dergelijke. Voor de kinderen is de Weekendopvang het best te omschrijven als een weekend logeren in een verantwoorde omgeving. De groepen die de weekends gezamenlijk doorbrengen, zijn heterogeen van samenstelling. $\mathrm{Zij}$ vormen een bont geheel van jongere en oudere kinderen, lichter en zwaarder gehandicapten, drukke en rustige kinderen.

De gezinnen kunnen van de Weekendopvang gebruik blijven maken tot het verstandelijk gehandicapte kind 18 of 20 jaar wordt. Als men vóor die tijd besluit met de opvang te stoppen, kan dat zijn omdat het kind de opvang niet leuk vindt, de ouders ontevreden zijn over de kwaliteit of de frequentie van de opvang, het kind definitief uit huis geplaatst of overleden is.

\section{Hypotheses}

Op basis van de doelstelling, de doelgroepen en de beperkingen daarin, en de redenen die ouders aangeven om zich voor Weekendopvang aan te melden, zijn twee hypotheses opgesteld ten aanzien van de kenmerken van de gezinnen die deze hulp aanvragen. Deze beginnen met het cijfer 5 :

In gezinnen die Weekendopvang aanvragen:

Hypothese 5-1: ervaren de ouders meer concrete problemen; en

Hypothese 5-2: voelen de ouders zich in psychosomatisch opzicht slechter, dan in gezinnen die geen Weekendopvang aanvragen.

De hypotheses ten aanzien van de effecten van Weekendopvang beginnen met een 6 . Zij luiden:

In gezinnen die Weekendopvang hebben:

Hypothese 6-1: heeft een grotere reductie in de concrete problemen van de ouders plaatsgehad; en

Hypothese 6-2: heeft een grotere toename in het psychosomatisch welbevinden van de ouders plaatsgehad, dan in gezinnen die geen Weekendopvang hebben. 


\subsection{Samenvatting: Hulpvormen ter begeleiding van het gezin}

Bij de onderhavige evaluatie van nieuwe vormen van gezinsbegeleiding in de zorg ten behoeve van. verstandelijk gehandicapten zijn vier afdelingen Praktisch Pedagogische Gezinsbegeleiding, zes projecten Praktische Thuishulp of Oppashulp en drie projecten Weekendopvang betrokken. Praktisch Pedagogische Gezinsbegeleiding tracht ouders te helpen bij problemen van opvoedkundige aard, Praktische Thuishulp tracht hulp te bieden bij problemen van praktische aard en Weekendopvang is tén van de mogelijkheden voor tijdelijke opvang van het gehandicapte kind buiten het gezin.

Van de drie hulpvormen is alleen Praktisch Pedagogische Gezinsbegeleiding in het reguliere WVC-beleid en het daarbij behorende financieringssysteem ingepast. PPG werkt met betaalde krachten, kent welomschreven intake- en indicatiecriteria en een duidelijke methodiek. Het is een kortdurende vorm van hulpverlening, die gericht is op vergroting van de draagkracht van ouders, met name wat hun opvoedingscompetentie betreft. Aangezien Praktisch Pedagogische Gezinsbegeleiding pas wordt toegekend wanneer een eenvoudig advies niet meer toereikend is, is de verwachting dat ouders die deze hulp krijgen toegewezen, hun leven met het verstandelijk gehandicapte kind als zeer belastend ervaren. Gezien de intensiteit en de professionaliteit van de hulpverlening wordt verwacht dat Praktisch Pedagogische Gezinsbegeleiding in staat is de draagkracht van de ouders te doen toenemen en daarmee hun stress te reduceren.

Vanaf 1991 is de coördinatie van Praktische Thuishulp bij de algemene eerste lijns voorzieningen in de gezondheidszorg ondergebracht. Weekendopvang is nog in afwachting van de invoering van een nieuwe verstrekkingensystematiek waarin naar alle waarschijnlijkheid "logeren" en "verzorgd verblijf voor korte duur" tot de mogelijkheden gaan behoren. Ten tijde van de dataverzameling voor het onderhavige onderzoek werden Praktische Thuishulp en Weekendopvang niet structureel gefinancierd. De projecten die aan het onderzoek deelnemen, werken dan ook, met uitzondering van de Weekendopvang in Zuidoost-Brabant, voornamelijk met vrijwilligers.

Praktische Thuishulp en Weekendopvang zijn primair gericht op een afname van de draaglast van ouders: beide hulpvormen nemen tijdelijk taken over van ouders of assisteren hen bij taken in de huishouding. Hoewel de intake- en indicatiecriteria van beide hulpvormen ruim geformuleerd zijn, mag verondersteld worden dat het voor ouders dikwijls moeilijk is te erkennen dat een paar extra handen in huis goed wan pas komen respectievelijk dat zij wel eens een weekend zonder het gehandicapte kind willen doorbrengen. Het is dan ook te verwachten dat ouders zich pas bij deze hulpvormen aanmelden wanneer zij een zekere mate van stress ervaren. Praktische Thuishulp kan zolang duren als de ouders wensen, Weekendopvang tot het 18de respectievelijk 20 ste levensjaar van het verstandelijk gehandicapte kind. Ouders zullen naar verwachting alleen van deze hulpvormen gebruik blijven maken wanneer zij als gevolg daarvan een afname in hun gevoelens van belasting ervaren. 



\section{Methode en instrumentontwikkeling}

Het onderhavige onderzoek concentreert zich rond twee vraagstellingen (zie 1.3). De eerste, betreffende de vraag welke variabelen de verschillen in stress tussen ouders van een thuis wonend kind met een verstandelijke handicap verklaren, vormt de theoretische achtergrond voor de tweede, die de evaluatie van drie hulpvormen betreft.

Hoofdstuk 6 gaat in op de methode die gebruikt is om deze vraagstellingen te beantwoorden. In $6.1 \mathrm{komt}$ de constructie van de vragenlijst aan de orde, in 6.2 de respondenten, procedure en respons en in 6.3 wordt per vraagstelling een korte beschrijving gegeven van de designs en de analyses.

\subsection{Vragenlijst}

Ter verwerving van de gegevens is gebruik gemaakt van een uitgebreide vragenlijst. Deze bestaat uit een algemeen gedeelte (6.1.1) en een gedeelte dat specifiek op de drie hulpvormen gericht is (6.1.2). De vragenlijst is geconstrueerd op basis van stresstheoretische literatuur, resultaten van studies naar de belasting van ouders van een kind met een werstandelijke handicap, literatuur over de te bestuderen hulpvormen en gesprekken met ouders en hulpverleners. Naar aanleiding van het commentaar van de 10 ouders aan wie de vragenlijst in concept is voorgelegd, is de lijst bijgesteld en in zijn definitieve vorm gegoten. De vragenlijst kan zonder hulp worden ingevuld.

\subsubsection{Algemeen gedeelte}

Het algemene gedeelte van de vragenlijst is aan alle respondenten voorgelegd. In dit gedeelte zijn de concepten uit de stressmodellen uitgewerkt (zie hoofdstuk 3). Het betreft de kenmerken van het verstandelijk gehandicapte kind, de ouders en de 
andere kinderen, de stress van ouders, dat wil zeggen hun concrete problemen en thun psychosomatisch onwelbevinden, de copingstijlen van ouders en de sociale steun die zil ondervinden.

Bijlage $A_{4}$ tabel 5 bevat een overzicht van deze variabelen, waarin onder andere de scoring en de betrouwbaarheden zijn opgenomen.

\section{Kenmerken wan het werstandelijk gehandicapte kind}

Van het verstandelijk gehandicapte kind zijn gegevens verzameld over:

(I) Gestacht.

(2) Verstandelljk niveau van functioneren. Op basis van de gebrikelijke classificatiesystemen (zie 3.21) zijn vier niveaus van verstandelijk functioneren onderscheiden: licht, matig, emstig en zeer enstig werstandelijk gehandicapt. Ter classificatie van de verstandelijk gehandicapten in deze studie is gebruik gemaakt van de toelatingscriteria van de verschillende vormen van dagbesteding, i.c. KDV's, DVO's en (Z)MLK's, In onduidelijke gevallen is tevens het oordeel van een expert gevraagd. Aangezien er weinig zeer enstig verstandelijk gehandicapten bij het onderzoek betrokken bleken te zijn, zijn deze uiteindelijk in tén groep samengebracht met de emstig verstandelijk gehandicapten.

(3) Leeftijd.

(4) Lichamelijke gezondheid. De volgende zeven dimensies zijn samen genomen om een algemeen beeld te krijgen van de gezondheid van de kinderen: het oordeel van de ouders over de lichamelijke gezondheid van het kind, de mobiliteit, de aard en ernst van lichamelijke klachten en aandoeningen, het medicijngebruik en de frequentic van periodes van ziekte, bezoeken aan een arts en ziekenhuisopnamen gedurende het jaar voorafgaand aan de invulling van de vragenlijst.

(5) Gedragsproblemen. Van 16 gedragsproblemen (zie bijlage A, tabel 1) is gevraagd hoe frequent het kind dit gedrag vertoont. In de lijst zijn aan de thuissituatie aangepaste items uit de schalen agressief en gemengd storend gedrag van de Storend Gedragsschaal voor Zwakzinnigen (SGZ; Kraijer \& Kema, 1977) opgenomen en items uit gesprekken met ouders en hulpverleners. Ter reductie van het aantal gedragsproblemen zijn factoranalyses volgens het principale componentenmodell uitgevoerd over de gegevens van 226 respondenten. Aangezien het item: "Mijn kind kan zich zelf niet bezighouden" op meerdere factoren ladingen groter dan .30 heeft, is dit item buiten de definitieve analyse gehouden. Het wordt als een apart gedragsprobleem beschouwd. Het item: "Mijn kind is overdreven nauwkeurig en

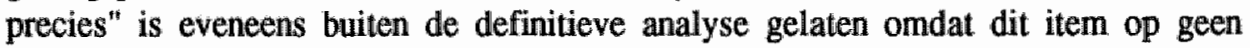
van de factoren een lading groter dan .30 heeft en veel ouders dit gedrag niet als een probleem blijken te ervaren.

Een factoranalyse over de resterende items levert vier factoren op met een eigenwaarde groter dan 1. Deze verklaren gezamenlijk $56.0 \%$ van de totale variantie en zijn na een varimax rotatie goed te interpreteren (zie bijlage $A$, tabel 1). Door ongewogen sommatie en middeling van de waarden van de items met een hoge lading op de betreffende factoren zijn vier schalen geconstrueerd: (a) extravert gedrag (7 items); (b) aandachtvragend gedrag (4 items); (c) eet- en slaapproblemen ( 2 items); en (d) introvert gedrag (2 items). Schaal (a) bevat voomamelijk items die 
in de SGZ verwijzen naar de meest storende gedragingen. Schaal (b) bestaat uit items die door ouders en hulpverleners naar voren zijn gebracht. De twee overige schalen bevatten gedragsproblemen die in de SGZ als minder storend worden opgevat en gescoord.

(6) Sociale redzaamheid. Over de socialle redzaamheid zijn 13 vragen gesteld (zie bijlage $A$, tabel 2). Deze zijn gedeeltelijk ontleend aan de schalen sociale gerichtheid en taal en taalgebruik van de Sociale Redzaamheidsschaal voor Zwakzinnigen (SRZ; Kraijer \& Kema, 1972) respectievelijk de Sociale Redzaamheidsschaal voor Kinderdagverblijfbezoekers (SRK; Van der Meulen \& Kema, 1976) en gedeeltelijk aan gesprekken met hulpverleners en ouders. Ter reductie van het aantal items is een factoranalyse volgens het principale componentenmodel uitgevoerd over de gegevens van 226 respondenten, waarbij alle items zijn betrokken. De eerste drie factoren hebben een eigenwaarde groter dan 1, verklaren gezamenlijk $60.1 \%$ van de totale variantie en zijn na een varimax rotatie goed te interpreteren (zie bijlage A, tabel 2). Door ongewogen sommatie en middeling van de waarden van de items met een hoge lading op de betreffende factoren zijn drie schalen gevormd: (a) sociale vaardigheden (7 items); (b) sociale gerichtheid (4 items); en (c) kwaliteit van het contact binmen het gezin ( 2 items). Vrijwel alle items uit de SRZ respectievelijk de SRK zijn in schaal (a) vervat. De meeste items in de schalen (b) en (c) zijn ontleend aan de gesprekken met ouders en hulpverleners.

(7) Zelfredzaamheid. Als indicatie voor de zelfredzaamheid is de totaalscore berekend over vier vragen ontleend aan de zelfstandigheidsschalen van de SRZ en de SRK (Kraijer \& Kema, 1972; Van der Meulen \& Kema, 1976), betreffende de zindelijkheid van het gehandicapte kind en de mate van zelfstandigheid van het kind met betrekking tot zijn of haar lichaamsverzorging, uit- en aankleden en eten.

\section{Kenmerken van de ouders}

Van de ouders zijn de volgende variabelen gemeten:

(I) Leeftijd van beide ouders.

(2) Sociale klasse. Op basis van het beroepsniveau van de hoofdkostwinner zijn de ouders in sociale klassen ingedeeld. Hierbij is de classificatie gevolgd van de Beroepenklapper, samengesteld door het Instituut voor Toegepaste Sociologie te Nijmegen (1975).

(3) Opleidingsniveau van beide ouders.

(4) Zelfwaardering. Aan de Self-Esteem Scale (Rosenberg, 1965) en de zelfbeoordelingsschalen ten aanzien van globale zelfwaardering (Helbing, 1982) zijn vijf vragen ontleend die na sommatie en middeling een beeld geven van de mate waarin ouders in het algemeen tevreden zijn over zichzelf.

\section{Kenmerken van de andere kinderen}

Met betrekking tot de andere kinderen in het gezin zijn vier soorten gegevens verzameld:

(1) Gemiddelde leeftijd van de andere kinderen.

(2) Totaal aantal broer(s) en/of zus(sen).

(3) Plaats van het verstandelijk gehandicapte kind in de kinderrij. 
andere kinderen, de stress van ouders, dat wil zeggen hun concrete problemen en hun psychosomatisch onwelbevinden, de copingstijlen van ouders en de sociale steun die zij ondervinden.

Bijlage $A_{x}$ tabel 5 bevat een overzicht van deze variabelen, waarin onder andere de scoring en de betrouwbaarheden zijn opgenomen.

\section{Kenmerken van het verstandelijk gehandicapte kind}

Van het verstandelijk gehandicapte kind zijn gegevens verzameld over:

(l) Geslacht.

(2) Verstandelijk niveau van functioneren. Op basis van de gebruikelijke classificatiesystemen (zie 3.2.1) zijn vier niveaus van verstandelijk functioneren onderscheiden: licht, matig, emstig en zeer emstig verstandelijk gehandicapt. Ter classificatie van de verstandelijk gehandicapten in deze studie is gebruik gemaakt van de toelatingscriteria van de verschillende vormen van dagbesteding, i.c. KDV's, DVO's en (Z)MLK's. In onduidelijke gevallen is tevens het oordeel van een expert gevraagd. Aangezien er weinig zeer emstig verstandelijk gehandicapten bij het onderzoek betrokken bleken te zijn, zijn deze uiteindelijk in eén groep samengebracht met de emstig verstandelijk gehandicapten.

(3) Leeftijd.

(4) Lichamelijke gezondheid. De volgende zeven dimensies zijn samen genomen om een algemeen beeld te krijgen van de gezondheid van de kinderen: het oordeel van de ouders over de lichamelijke gezondheid van het kind, de mobiliteit, de aard en ernst van lichamelijke klachten en aandoeningen, het medicijngebruik en de frequentie van periodes van ziekte, bezoeken aan een arts en ziekenhuisopnamen gedurende het jaar voorafgaand aan de invulling van de vragenlijst.

(5) Gedragsproblemen. Van 16 gedragsproblemen (zie bijlage A, tabel 1) is gevraagd hoe frequent het kind dit gedrag vertoont. In de lijst zijn aan de thuissituatie aangepaste items uit de schalen agressief en gemengd storend gedrag van de Storend Gedragsschaal voor Zwakzinnigen (SGZ; Kraijer \& Kema, 1977) opgenomen en items uit gesprekken met ouders en hulpverleners. Ter reductie van het aantal gedragsproblemen zijn factoranalyses volgens het principale componentenmodell uitgevoerd over de gegevens van 226 respondenten. Aangezien het item: "Mijn kind kan zich zelf niet bezighouden" op meerdere factoren ladingen groter dan .30 heeft, is dit item buiten de definitieve analyse gehouden. Het wordt als een apart gedragsprobleem beschouwd. Het item: "Mijn kind is overdreven nauwkeurig en precies" is eveneens buiten de definitieve analyse gelaten omdat dit item op geen van de factoren een lading groter dan . 30 heeft en veel ouders dit gedrag niet als een probleem blijken te ervaren.

Een factoranalyse over de resterende items levert vier factoren op met een eigenwaarde groter dan 1. Deze verklaren gezamenlijk $56.0 \%$ van de totale variantie en zijn na een varimax rotatie goed te interpreteren (zie bijlage $\mathrm{A}$, tabel 1). Door ongewogen sommatie en middeling van de waarden van de items met een hoge lading op de betreffende factoren zijn vier schalen geconstrueerd: (a) extravert gedrag ( 7 items); (b) aandachtvragend gedrag ( 4 items); (c) eet- en slaapproblemen (2 items); en (d) introvert gedrag ( 2 items). Schaal (a) bevat voomamelijk items die 
in de SGZ verwijzen naar de meest storende gedragingen. Schaal (b) bestaat uit items die door ouders en hulpverleners naar voren zijn gebracht. De twee overige schalen bevatten gedragsproblemen die in de SGZ als minder storend worden opgevat en gescoord.

(6) Sociale redzaamheid. Over de sociale redzaamheid zijn 13 vragen gesteld (zie bijlage A, tabel 2). Deze zijn gedeeltelijk ontleend aan de schalen sociale gerichtheid en taal en taalgebruik van de Sociale Redzaamheidsschaal voor Zwakzinnigen (SRZ; Kraijer \& Kema, 1972) respectievelijk de Sociale Redzaamheidsschaal voor Kinderdagverblijfbezoekers (SRK; Van der Meulen \& Kema, 1976) en gedeeltelijk aan gesprekken met hulpverleners en ouders. Ter reductie van het aantal items is een factoranalyse volgens het principale componentenmodel uitgevoerd over de gegevens wan 226 respondenten, waarbij alle items zijn betrokken. De eerste drie factoren hebben een eigenwaarde groter dan 1 , verklaren gezamenlijk $60.1 \%$ van de totale variantie en zijn na een varimax rotatie goed te interpreteren (zie bijlage A, tabel 2). Door ongewogen sommatie en middeling van de waarden van de items met een hoge lading op de betreffende factoren zijn drie schalen gevormd: (a) sociale vaardigheden (7 items); (b) sociale gerichtheid (4 items); en (c) kwaliteit van het contact binnen het gezin ( 2 items). Vrijwell alle items uit de SRZ respectievelijk de SRK zijn in schaal (a) vervat. De meeste items in de schalen (b) en (c) zijn ontleend aan de gesprekken met ouders en hulpverleners.

(7) Zelfredzaamheid. Als indicatie voor de zelfredzaamheid is de totaalscore berekend over vier vragen ontleend aan de zelfstandigheidsschalen van de SRZ en de SRK (Kraijer \& Kema, 1972; Van der Meulen \& Kema, 1976), betreffende de zindelijkheid van het gehandicapte kind en de mate van zelfstandigheid van het kind met betrekking tot zijn of haar lichaamsverzorging, uit- en aankleden en eten.

\section{Kenmerken van de ouders}

Van de ouders zijn de volgende variabelen gemeten:

(1) Leeftijd wan beide ouders.

(2) Sociale klasse. Op basis van het beroepsniveau van de hoofdkostwinner zijn de ouders in sociale klassen ingedeeld. Hierbij is de classificatie gevolgd van de Beroepenklapper, samengesteld door het Instituut voor Toegepaste Sociologie te Nijmegen (1975).

(3) Opleidingsniveau van beide ouders.

(4) Zelfwaardering. Aan de Self-Esteem Scale (Rosenberg, 1965) en de zelfbeoordelingsschalen ten aanzien van globale zelfwaardering (Helbing, 1982) zijn vijf vragen ontleend die na sommatie en middeling een beeld geven van de mate waarin ouders in het algemeen tevreden zijn over zichzelf.

\section{Kenmerken van de andere kinderen}

Met betrekking tot de andere kinderen in het gezin zijn vier soorten gegevens verzameld:

(I) Gemiddelde leeftijd van de andere kinderen.

(2) Totaal aantal broer(s) en/of zus(sen).

(3) Plaats van het verstandelijk gehandicapte kind in de kinderrij. 
(4) Relatie van het verstandelijk gehamdicapte kind met broer(s) en/of zus(sen). De ouders is gevraagd aan te geven hoe goed het gehandicapte kind het kan vinden met elk van de andere kinderen. Deze scores zijn gesommeerd en gemiddeld om grotere met kleinere gezinnen te kunnen vergelijken.

\section{Stress van ouders}

Ten aanzien van de stress van ouders zijn gegevens verzameld over hun concrete problemen en hun psychosomatisch onwelbevinden (zie 3.1).

(I) Concrete problemen. De ouders zijn 13 positief en 13 negatief geformuleerde uitspraken voorgelegd die refereren aan de druk die een verstandelijk gehandicapt kind op het gezin kan leggen (zie bijlage A, tabellen $3.1 \mathrm{t} / \mathrm{m} \mathrm{3.3).} \mathrm{De} \mathrm{problemen}$ waarnaar deze uitspraken verwijzen, zijn ontleend aan gesprekken met ouders en hulpverleners, literatuur over veel voorkomende problemen (Landelijke Commissie Gezinsbegeleiding, 1982), eigen vooronderzoek (Van Berkum, Bremer, Kok \& Wijffels, 1988) en bestudering met betrekking tot hun relevantie van de Amerikaanse Questionnaire on Resources and Stress (QRS; Holroyd, 1974; Holroyd, Brown, Wikler \& Simmons; 1975), de verkorte versie daarvan (QRS-F; Friedrich, Greenberg \& Crnic, 1983; Friedrich, Wiltumer \& Cohen, 1985) en de uitsprakenlijst die Janssen (1982) ontwikkelde als diagnostisch instrument voor maatschappelijk werkenden. De ouders is gevraagd naar de mate waarin zij deze problemen ervaren. Uit de 26 items zijn vier schalen geconstrueerd. De eerste is gevormd door ongewogen sommatie en middeling van de 4 items die refereren aan: (a) problemen met betrekking tot de partner (zie bijlage A, tabel 3.1). De tweede schaal is geconstrueerd door ongewogen sommatie en middeling van de 6 items die verwijzen naar: (b) zorgen over de ontwikkeling van de andere kinderen (zie bijlage A, tabel 3.2). De twee overige schalen zijn gebaseerd op de factoranalyses die over de resterende 16 items zijn uitgevoerd volgens het principale componentenmodel. Het item: "Ik ben bezorgd over de toekomst van mijn verstandelijk gehandicapte kind" heeft op geen van de factoren een lading groter dan .30 en is uit de analyse verwijderd. In de definitieve analyse hebben de eerste drie factoren een eigenwaarde groter dan 1 en verklaren gezamenlijk $53.8 \%$ van de variantie (zie bijlage $\mathrm{A}$, tabel 3.3 ). Door ongewogen sommatie en middeling van de waarden van de items met een hoge lading op de eerste twee factoren zijn de schalen: (c) gezinsverstoring ( 8 items), en (d) praktische druk (4 items) gevormd.

De vier schalen die in het onderhavige onderzoek gebruikt zijn, zijn moeilijk te vergelijken met schallen die in andere studies geconstrueerd zijn. Uiteenlopende doelstellingen leiden immers tot verschillend samengestelde uitsprakenlijsten. Uit de studies van Janssen (1982) en Friedrich et al. (1983) komen bijvoorbeeld schalen naar voren die hetzij slecht aansluiten bij de evaluatieve vraagstelling van het onderhavige onderzoek, zoals "tobben over de ontwikkelingsmogelijkheden van het kind" en "schuld- en schaamtegevoelens", hetzij in het onderhavige onderzoek als onafhankelijke variabelen zijn opgevat, zoals "kenmerken van het gehandicapte kind". Uit de factoranalyses in beide geciteerde studies komt als eerste factor echter een schaal naar voren die inhoudelijk in grote mate overeenkomt met schaal (c) gezinsverstoring, maar tevens items bevat uit de schalen (a), (b) en (d). Om deze reden en vanwege de samenhang tussen de vier schalen in het onderhavige onderzoek 
$(.42 \leq \mathrm{r} \leq .63 ; \mathrm{p}<.001$, een-zijdig), kan geconcludeerd worden dat deze vier schalen verdere verfigningen zijn van een probleemgebied dat als "druk op de gezinsleden" kan worden omschreven. Als zodanig sluiten zij goed aan bij de evaluatieve doelstelling van bet onderzoek.

De derde factor uit de analyse (zie bijlage $A$, tabel 3.3) verwijst naar gevoelens van sociale isolatie. Gezien de conceptuele en statistische overeenkomsten met een aantal maten voor het gebrek aan sociale steun, is de schaal die op deze factor gebaseerd is, niet als een concreet probleem opgevat maar betrokken bij de operationalisatie van sociale steun. Dit is in overeenstemming met de analyses van Friedrich et al. (1983), waaruit blijkt dat geen van de items uit de oorspronkelijke QRS-schaal "sociale steun" voorkomt in de verkorte QRS-F. De auteurs raden dan ook aan sociale steun als een aparte variabele te meten, ook al vanwege de mogelijk interveniërende rol van deze variabele in het stressproces.

(2) Psychosomatisch onwelbevinden. De ouders zijn 18 items voorgelegd die na sommatie en middeling een indicatie geven van hun psychosomatisch onwelbevinden. In dit instrument verwijzen 6 items naar depressieve gevoelens. Deze zijn ontleend aan de Self-Rating Depression Scale en de Nederlandse vertaling daarvan (Dijkstra, 1973; Dijkstra, 1974; Zung, 1965; Zung, Richards \& Short, 1965). Voorts refereren 5 items aan neurotische labiliteit voor zover geuit in psychoneurotische klachten. Deze items zijn ontleend aan de Inadequatie-schaal van de Nederlandse Persoonlijkheids Vragenlijst (NPV; Luteijn, Starren \& Van Dijk, 1985) en de Neuroticismeschaal van de Amsterdamse Biografische Vragenlijst (ABV; Wilde, 1970). Tot slot zijn 7 vrägen naar psychosomatische klachten opgenomen, die zijn gedistilleerd uit de Vragenlijst voor Onderzoek naar de Ervaren Gezondheidstoestand (VOEG; Dirken, 1969), de NS-schaal van de ABV die neurotische labiliteit meet voor zover gemanifesteerd in functionele lichamelijke klachten (Wilde, 1970) en de somatisatieschalen van Nederlandse bewerkingen van de Hopkins Symptom Checklist (HSCL; Luteijn, Kok, Hamel \& Poiesz, 1979), de verkorte MMPI (Luteijn \& Kingma, 1979) en de Symptom Checklist (SCL-90; Arrindell \& Ettema, 1981).

\section{Coping}

De ouders zijn 14 items uit de Utrechtse Coping Lijst (UCL; Schreurs, Van de Willige, Tellegen \& Brosschot, 1988) voorgelegd met de vraag hoe vaak zij in het algemeen op de beschreven manier reageren op problemen of moeilijke situaties. Deze items, i.c. van elk van de zeven UCL-subschalen die twee items met de hoogste lading op de betreffende factor in de onderzoeken van Schreurs et al. (1988), meten copingstijlen en niet de wijze waarop ouders met een specifiek probleem omgaan (zie 2.2). Ter reductie van het aantal copingstijlen is een factoranalyse volgens het principale componentenmodel uitgevoerd op de gegevens van 226 respondenten. De eerste vijf factoren hebben een eigenwaarde groter dan 1 , verklaren samen $64.3 \%$ van de variantie en zijn na een varimax rotatie goed te interpreteren (zie bijlage $A$, tabel 4). Door ongewogen sommatie en middeling van de items met een hoge lading op de respectievelijke factoren zijn vijf copingschalen gevormd:

(I) Depressief reactiepatroon (3 items). De beide items uit de UCL-subschaal "depressief reactiepatroon" hebben een hoge positieve lading op deze factor. De 
hoge negatieve lading van item 3: "Ik bedenk me dat na regen zonneschijn komt", uit de UCL-subschaal "geruststellende gedachten", is een begrijpelijke aanvulling. De schaal komt inhoudelijk overeen met de UCL-subschaal "depressief reactiepatroon". Deze copingstijl heeft een emotieregulerende functie en verwijst naar een intrapsychische activiteit, namelijk het zich somber en piekerend in zich zelf terugtrekken.

(2) Sociale steun zoeken (4 items). Beide items uit de UCL-subschaall "sociale steun zoeken" zijn in deze schaal opgenomen. Daamaast hebben item 4: "Ilk bedenk verschillende mogelijkheden om het probleem op te lossen" (UCL-subschaal "actief problemen aanpakken") en item 7: "Ik bedenk me dat anderen het ook wel eens moeilijk hebben" (UCL-subschaal "geruststellende gedachten") eveneens een hoge positieve lading op deze factor. Naast de emotiegerichte functie van het zoeken van troost en begrip heeft de copingstijl "sociale steun zoeken" in de onderhavige onderzoekspopulatie een actieve probleemgerichte component, namelijk het bespreken van problemen met anderen om verschillende oplossingen te kunnen bedenken (zie ook de negatieve correlatie met "vermijding", tabel 6.1). De copingstijl "sociale steun zoeken" omvat zowel gedragsmatige als cognitieve activiteiten.

(3) Palliatieve reactie (2 items). De items 8: "Ik verdrijf mijn zorgen tijdelijk door er even uit te gaan" en 9: "Ik zoek afleiding" (UCL-subschaal "palliatieve reactie") zijn de enige items met een hoge lading op deze factor. De copingstijl "palliatieve reactie" lijkt in het onderhavige onderzoek een meer neutrale betekenis te hebben dan in de studies van Schreurs et al. (1988). In tegenstelling tot de bevindingen van deze auteurs correleert de copingstijl in de onderhavige onderzoekspopulatie namelijk niet significant met de copingstijlen "depressief reactiepatroon", "vermijding" en "expressie van emoties" (zie tabel 6.1). Het zoeken van afleiding lijkt voor ouders met een verstandelijk gehandicapt kind een vrij gebruikelijke reactie op de voortdurende aanwezigheid van grotere en kleinere moeilijkheden. Het is een gedragsmatige copingstijl met een emotieregulerende functie.

\section{Tabel 6.1}

Intercorrelaties copingstijlen ( $n=226$ )

\begin{tabular}{lcccc}
\hline Copingstijlen & 2 & 3 & 4 & 5 \\
\hline 1. Depressief reactiepatroon & -.11 & -.05 & $.27^{* *}$ & $.25^{*}$ \\
2. Sociale steun zoeken & - & $.35^{* *}$ & $-.24^{*}$ & $.22^{*}$ \\
3. Palliatieve reactie & & - & -.04 & .04 \\
4. Vernijding & & & - & -.05 \\
5. Expressie van emoties & & & & -
\end{tabular}

${ }^{*} \mathrm{p}<.01$, twee-zijdig. ${ }^{* *} \mathrm{p}<.001$, twee-zijdig.

(4) Vermijding (3 items). Beide items uit de UCL-subschaal "vermijding" hebben een hoge positieve lading op deze factor, terwijl item 12: "Ik ga doelgericht te werk om het probleem op te lossen" (UCL-subschaal "actief problemen aanpakken") een hoge negatieve lading heeft. De copingstijl "vermijding" omvat vooral gedragsmatige activiteiten. Het is de enige probleemgerichte copingstijl die in de populatie van ouders van een kind met een verstandelijke handicap is aangetroffen, zij het dat het 
bij deze copingstijl gaat om het min of meer actief uit de weg gaan van problematische situaties.

(5) Expressie van emoties (2 items). De beide items uit de UCL-subschaal "expressie van emoties" zijn de enige met een hoge lading op deze factor. Inhoudelijk komt deze copingstijl overeen met de corspronkelijke UCL-subschaal. Het is een emotieregulerende copingstijl waarbij het gaat om het afreageren van spanningen, verdriet of boosheid.

\section{Sociale steun}

De steun aan ouders door mensen in hun sociale ongeving is op zes manieren gemeten:

\section{(1) Burgerlijke staat.}

(2) Partnersteun. De indicatie voor partnersteun, alleen berekend voor ouders die gehuwd zijn of samenwonen, is het antwoord op de vraag of de partner genoemd is als éen van de mensen die emotionele steun geven.

(3) Totaal aantal steungevenden.

(4) Lidmaatschap van een geloofsgemeenschap of levensbeschouwelijke groepering.

(5) Steun uit het geloof of de levensbeschouwing. Aan ouders die zich tot een geloofsgemeenschap of levensbeschouwelijke groepering rekenen, is gevraagd in hoeverre zij hun geloof of levensovertuiging als verlichtende of verzwarende factor ervaren bij de zorg voor het verstandelijk gehandicapte kind.

(6) Sociale isolatie. Over de antwoorden op vragen naar (a) de aan- of afwezigheid van mensen op wie men een beroep kan doen bij emotionele problemen, (b) de tevredenheid over de aldus verkregen steun en (c) de tevredenheid over het aantal steungevenden, is een totaalscore berekend. Deze hangt in aanzienlijke mate samen met de schaal die is geconstrueerd op basis van de derde factor van de analyse op de concrete problemen van ouders (zie bijlage A, tabel 3.3). Beide maten, in dezelfde richting gecodeerd, verwijzen naar het gevoel er alleen voor te staan. De gesommeerde en gemiddelde scores geven dan ook een indicatie van de gevoelens van sociale isolatie.

Burgerlijke staat, het totaal aantal steungevenden en het lidmaatschap van een geloofsgemeenschap of levensbeschouwelijke groepering refereren aan structurele kenmerken van het sociale netwerk van ouders. Partnersteun, steun uit het geloof en gevoelens van sociale isolatie verwijzen naar de ervaren beschikbaarheid respectievelijk afwezigheid van steun uit de sociale omgeving (zie 2.3.3).

De samenhangen tussen deze indices voor sociale steun zijn met Student's t-toetsen, chi $^{2}$-toetsen en Pearson correlatiecoëfficiènten onderzocht. Van de 13 mogelijke verbanden zijn er 3 significant. Gehuwde of samenwonende ouders voelen zich minder sociaal geisoleerd dan ongehuwde of alleenwonende ouders $(t(163)=2.73$; $\mathrm{p}<.01$, twee-zijdig). Van de gehuwde of samenwonende respondenten noemen ouders die steun wan hun partner ontvangen, in het totaal meer mensen die hen emotioneel steunen dan ouders die niet door hun partner ondersteund worden $(t(152)=-2.51$; $p<.01$, twee-zijdig). Er bestaat eveneens een positieve samenhang tussen het totaal aantal steungevenden en de steun die men uit het geloof of de levensbeschouwing ervaart ( $r=.24 ; p<.01$, twee-zijdig). 


\subsubsection{Speciffiek gedeelte}

Het specifieke gedeelte van de vragenlijst bevat vragen over Praktisch Pedagogische Gezinsbegeleiding (PPG), Praktische Thuishulp (PT) en Weekendopvang (WO).

\section{Voormeting}

Bij de voormeting zijn aan alle ouders dezelfde vragen gesteld:

(I) "Heeft u wel eens van PPG, PT respectievelijk WO gehoord?"

(2) "Heeft $u$ behoefte aan hulp bij de opvoeding van en de omgang met uw gehandicapte kind, respectievelijk aan hulp bij problemen van praktische aard respectievelijk aan opvang van uw kind gedurende de weekends?"

(3) "Heeft u PPG, PT of WO aangevraagd?" en zo ja:

(a) "Om welke reden(en) c.q. met welke hulpvra(a)g(en)?"

(b) Bij PT en WO: "Hoe frequent hoopt u van de hulp gebruik te kunnen maken?"

\section{Nameting}

Bij de nameting zijn de ouders alleen vragen gesteld over de hulp die zij gedurende het jaar ervoor hebben ontvangen. De ouders die PPG, PT respectievelijk WO hebben (gehad), is gevraagd naar:

(I) De vormgeving van de hulp. Bij PPG is gevraagd: "Hoe tevreden bent $\mathrm{u}$ over

(a) de duur en de frequentie van PPG?"

(b) de contacten tussen de pedagogisch werkende en u zelf, uw verstandelijk gehandicapte kind en de andere gezinsleden?"

(c) de wekelijkse en de evaluatiegesprekken, de schriftelijke verslagen, de praktische aanwijzingen, de opdrachten van de pedagogisch werkende en het werken volgens een vast werkplan?"

Bij Praktische Thuishulp is gevraagd: "Hoe tevreden bent u over

(a) de frequentie van de hulp?"

(b) de contacten tussen de vrijwilliger en u zelf, uw verstandelijk gehandicapte kind en de andere gezinsleden?"

(c) uw contacten met de coördinator of de contactpersoon van de Praktische Thuishulpcentrale?"

Bij Weekendopvang is gevraagd: "Hoe tevreden bent u over

(a) de frequentie van de Weekendopvang?"

(b) uw contact met de leiding van de Weekendopvang?"

(c) de verzorging en begeleiding van de groepen, de accommodatie, de activiteiten, de planning en de groepssamenstelling?"

(2) De inhoud van de hulp. De redenen die de ouders gaven voor hun aanmelding bij de hulp c.q. de hulpvragen die zij toen hadden (zie bij "voormeting", vraag 3a), zijn in de nameting in dezelfde bewoordingen aan hen voorgelegd met de vraag: "In hoeverre heeft de hulp voldaan aan deze verwachtingen c.q. in hoeverre zijn deze hulpvragen beantwoord?"

(3) De algemene satisfactie met de hulp:

(a) "In hoeverre bent $u$ in het algemeen tevreden over de hulp?" 
(b) "Zou a gezinnen met gelijksoortige problemen aanraden zich bij PPG, PT respectievelijk WO aan te melden?"

Bij PPG is tevens gevraagd naar de mate waarin het uiteindelijke doel van de hulpverlening is bereikt: "In hoeverre heeft $u$ het gevoel zelf weer verder te kunnen nu Praktisch Pedagogische Gezinsbegeleiding is afgesloten?"

Bij WO is tevens gevraagd: "Zijn de weekends waarin uw gehandicapte kind van de Weekendopvang gebruik maakt, in sfeer en in de activiteiten die uw gezin onderneemt, anders dan de weekends waarin uw kind thuis is? ? $^{\text {ts }}$

\subsection{Respondenten, procedure en respons}

Met de bij het onderzoek betrokken afdelingen Praktisch Pedagogische Gezinsbegeleiding en projecten Praktische Thuishulp en Weekendopvang (zie hoofdstuk 5) is een standaardprocedure overeengekomen ten aanzien van het benaderen van respondenten voor het onderzoek. Het verzoek on hulp behandelde men op de reguliere wijze. Als de hulpvraag gehonoreerd werd, schatten de afdelingen en projecten in of de gezimnen tot de doelgroep van het onderzoek behoorden (soms verleende men hulp aan ouders van een normaal begaafd kind) en of het gewenst was de ouders om medewerking aan het onderzoek te verzoeken (soms beoordeelde men de vragenlijst als te belastend of als verstorend voor de hulpverleningsrelatie). Konden beide vragen positief beantwoord worden, dan vroeg de hulpverlener, in verband met de privacy van de cliënten, de ouders toestemming hun naam aan de onderzoeker door te geven.

Voor de formatie van een controlegroep is aan directeuren van dagverblijven voor kinderen en ouderen, en van scholen voor moeilijk en zeer moeilijk lerende kinderen gevraagd a-select uit hun leerlingenbestand enkele namen van gezinnen te lichten die op dat moment geen gebruik maakten van noch een hulpaanvraag hadden ingediend bij de te onderzoeken hulpvormen. De directeuren vroegen deze ouders om toestemming hun naam aan de onderzoeker door te geven.

De onderzoeker stuurde de ouders vervolgens een brief met informatie over het doel, de achtergronden en de werkwijze van het onderzoek, alsmede over de tijdsinvestering die invulling van de vragenlijst zou vereisen (zie bijlage $B$, brief 1 ). Enige dagen daarna vroeg zij de ouders te willen meewerken aan het onderzoek. Als zij daarin toestemden, werd de vragenlijst verstuurd en een afspraak gemaakt voor het ophalen van de ingevulde lijst. De vragenlijst ging vergezeld van een brief met gedetailleerde informatie over de wijze waarop de lijst diende te worden ingevuld (zie bijlage B, brief 2). Hierin is onder andere benadrukt dat de vragenlijst door éen van beide ouders moest worden ingevuld. Aangezien het in onze maatschappij gebruikelijk is dat moeders meer tijd besteden aan de verzorging en opvoeding van kinderen dan vaders, is de moeders gevraagd dit te willen doen. In $94 \%$ van de gezinnen hebben de moeders de lijst inderdaad ingevuld.

De onderzoeker haalde de ingevulde vragenlijsten bij alle ouders op ter beperking van de non-respons en het aantal missende waarden. Veel ouders bleken het 
bowendien prettig te vinden hun antwoorden in een persoonlijk gesprek te kumnen toelichten. Tijdens deze gesprekken, die gemiddeld ongeveer eén uwr duurden, ging de onderzoeker tevens na of de invulling van de vragenlijst, vanwege het ingrijpende karakter van de vragen, niet een zo grote belasting was geweest dat de hulpverlening daarvan in kennis moest worden gesteld: dit bleek in éen gezin het geval. Het persoonlijke contact droeg er bovendien toe bij dat vele ouders ook hun medewerking aan de nameting verleenden. De voormetingen zijn gerealiseerd tussen januari 1988 en januari 1990.

De ouders uit de controlegroep en de ouders die Praktische Thuishulp of Weekendopvang hadden aangevraagd, ontvingen een jaar na de voormeting een brief waarin hun medewerking nogmaals gevraagd werd (zie bijlage B, brief 3 ). De ouders die Praktisch Pedagogische Gezinsbegeleiding hadden aangevraagd, ontvingen deze brief ook een jaar na de voormeting tenzij de hulpverlening langer dan een jaar duurde. In die gezinnen werd de nameting uitgesteld totdat de hulp was afgesloten. De effecten van Praktisch Pedagogische Gezinsbegeleiding kunnen in tegenstelling tot die van de twee andere hulpvormen pas worden nagegaan nadat de hulpverleningscyclus formeel is afgerond. Ook bij de nameting haalde de onderzoeker de ingevulde vragenlijsten bij alle ouders op. De nametingen vonden plaats tussen januari 1989 en februari 1991.

In tabel 6.2 is een overzicht gegeven van het aantal ouders in de controle- en de hulpverleningsgroepen dat is betrokken bij de analyses in de voor- respectievelijk de nameting. Bij de voormeting is in de hulpverleningsgroepen een verschil te constateren tussen (1) het aantal aangemelde en (2) het aantal aan de onderzoeker doorgegeven ouders. De redenen voor deze verschillen zijn:

(a) het gezin behoort niet tot de doelgroep van het onderzoek (PPG en PT);

(b) de hulpverleners achten de vragenlijst te belastend voor het gezin (PPG);

(c) opname in het onderzoek kan de hulpverleningsrelatie schaden (PPG);

(d) het gezin heeft gedurende de periode van gegevensverwerving geen gebruik van de hulp kunnen maken, vanwege een gebrek aan vrijwilligers (PT) of het ontbreken van een plaats (WO); en

(e) de hulpverlener is vergeten de naam van het gezin aan de onderzoeker door te geven (PPG en PT).

De in tabel 6.2 bij de voormeting weergegeven responspercentages zijn berekend op basis van het aantal gezinnen dat bij de onderzoeker bekend was.

Bij de nameting zijn in totaal 45 gezinnen niet benaderd de vragenlijst nogmaals in te vullen. De redenen hiervoor zijn:

(a) een definitieve uithuisplaatsing van het gehandicapte kind tussen de voor- en de nameting (controlegroep, PPG en WO);

(b) de ouders hebben in de tussentijd hulp gekregen van éen van de te onderzoeken hulpvormen (controlegroep);

(c) de ouders hebben geen hulp gehad (PPG, PT en WO); en

(d) de ouders zijn ten tijde van de nameting al weer met de hulp gestopt (PT en WO). 
De responspercentages bij de nameting hebben alleen betrekking op de ouders die voor de nameting benaderd zijn.

\section{Tabel 6.2}

Aantallen aangemelde en bij de analyses betrokken ouders per groep en responspercentages: voor- en nameting

\begin{tabular}{crll}
\multicolumn{4}{c}{ Groepen } \\
\hline Controle & PPG & PT & WO \\
(n) & (n) & (n) & (n)
\end{tabular}

Voormeting:

(1) Aangemeld

(2) Aan onderzoeker doorgegeven

(3) Niet bereikt

(4) Geweigerd

Bij de analyses betrokken

Responspercentage

Nameting:

(1) Niet benaderd

(2) Niet bereikt

(3) Geweigend

Bij de analyses betrokken

Responspercentage

$\begin{array}{rrrc}- & 105 & 60 & 67 \\ 68 & 61 & 39 & 65 \\ 3 & - & 8 & - \\ 5 & 3 & 6 & 1 \\ 60 & 58 & 25 & 64 \\ 88 \% & 95 \% & 64 \% & 98 \% \\ 7 & 10 & 11 & 17 \\ 3 & - & 3 & 3 \\ 3 & - & - & 2 \\ 47 & 48 & 11 & 42 \\ 89 \% & 100 \% & 79 \% & 89 \%\end{array}$

\subsection{Analyses en designs}

De analyses en designs behorend bij de eerste, theoretische vraagstelling worden in 6.3.1 besproken, de analyses en designs die bij de tweede, evaluatieve vraagstelling zijn gebruikt, worden in 6.3.2 weergegeven.

\subsubsection{Theoretische vraagstelling: Beschrijving van de analyses}

De variabelen uit de drie modellen die in hoofdstuk 3 zijn opgesteld ter verklaring van de verschillen in stress tussen ouders van een kind met een verstandelijke handicap, zijin in 6.1.1 nader geconcretiseerd. De schema's $6.1,6.2$ en 6.3 geven achtereenvolgens het uitgewerkte basismodel, copingmodel en sociale-steunmodel weer.

Deze schema's bevatten eén blok meer dan de theoretische schema's in hoofdstuk 3 , namelijk blok 4 "leeftijden van de gezinsleden". De leeftijden van het gehandicapte kind, zijn of haar ouders en broer(s) en/of zus(sen) bleken zo sterk samen te hangen $(.71 \leq \mathrm{r} \leq .91 ; \mathrm{p}<.001)$ dat deze variabelen samen in een apart blok zijn ondergebracht.

De onderzoeksdesigns waarmee is nagegaan in hoeverre de empirische gegevens in overeenstemming zijn met de theoretische modellen, kunnen als cross-sectioneel omschreven worden. In elk gezin zijn de gegevens die bij deze analyses gebruikt 


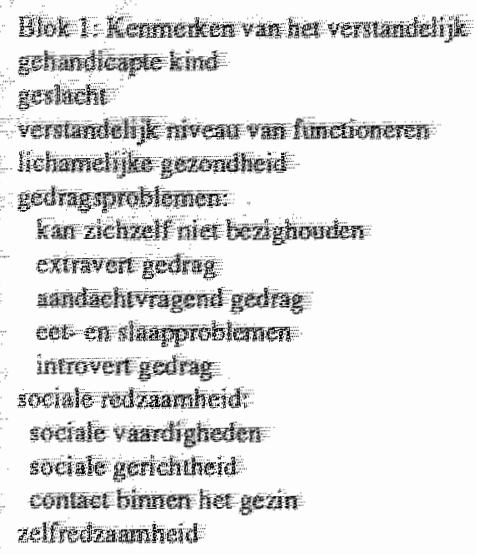

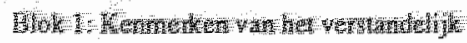
yow

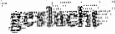

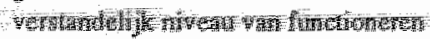

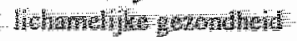

gedrag

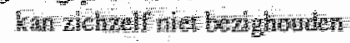

a rath

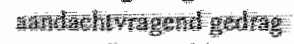

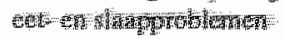

in

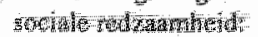

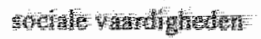

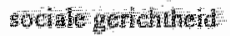

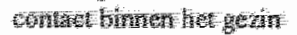

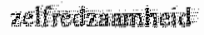

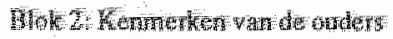

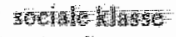

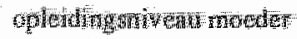

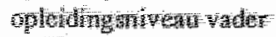

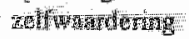

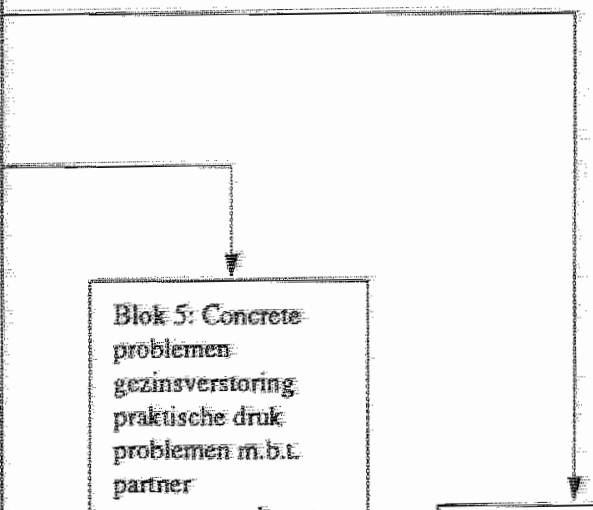

Dow 6 Prydro wrmatseh onwelbetinden-
26 mon ore de mis

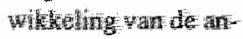

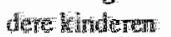

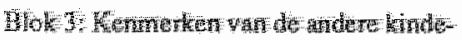
wक्ष

Farith

plaats k.w.h. in de kindertij

relatie k.w.h. met broer(s) enfof zus(sem)

Blok 4: Leeftijden van de gezinsleden leenije k.v.h.

leeftijd moeder

loefitijl vader

gemiddelde leeftijd andere kinderen 
zijn, op hetzelfde moment verzameld. De drie modellen veronderstellen een zekere oorzakelijke of althans hiërarchische ordening tussen verschillende erin opgenomen blokken van variabelen. Deze modellen geven even zo vele visies weer op de werkelijkheid in gezinnen met een verstandelijk gehandicapt kind. Hoewel deze visies met theoretische en onderzoeksmatige argumenten zijn onderbouwd (zie hoofdstuk 2 en 3), moeten conclusies over de causaliteit van de verbanden met de nodige voorzichtigheid worden geinterpreteerd, aangezien deze op correlationele gegevens zijn gebaseerd.

Bij de analyses ten aanzien van de theoretische vraagstelling zijn de 181 ouders betrokken die de vragenlijst tussen januari 1988 en april 1989 voor de eerste keer invulden en die naast het verstandelijk gehandicapte kind één of meer andere kinderen hebben.

\section{Het basismodel (schema 6.1)}

De analyses ten aanzien van het basismodel zijn in drie stappen uitgevoerd. In de eerste stap is getracht de 12 potentieel stressvolle kenmerken van het verstandelijk gehandicapte kind tot een geringer aantal daadwerkelijk stresserende kenmerken te reduceren. Hiertoe is een multiple discriminant analyse uitgevoerd op elk van de vier concrete problemen van de ouders (blok 5) met de potentieel stressvolle kenmerken van het verstandelijk gehandicapte kind (blok 1) als onafhankelijke variabelen. Met deze multivariate analyse (Pedhazur, 1982) is nagegaan welke kenmerken van het kind bijdragen aan het onderscheid tussen ouders die veel, matig en weinig problemen ervaren. De kenmerken die bij éen of meer problemen een discriminerende waarde hebben, zijn tot nieuwe schalen samengevoegd, "de stresserende kenmerken van het verstandelijk gehandicapte kind". Deze zijn in alle volgende analyses gebruikt, terwijl de kenmerken die geen discriminerende waarde hebben, verder buiten beschouwing zijn gebleven.

In de tweede stap is nagegaan welke kenmerken van de verstandelijk gehandicapte kinderen, de ouders en de andere kinderen de verschillen in de ernst van de concrete problemen van de ouders het best kunnen verklaren. Hiertoe is voor elk van de vier concrete problemen (blok 5) een multiple regressie analyse uitgevoerd met alle variabelen uit de blokken $1 \mathrm{t} / \mathrm{m} 4$ als mogelijke predictoren.

In de derde stap is tenslotte nagegaan welke kenmerken van de verstandelijk gehandicapte kinderen, van de ouders en van de andere kinderen en welke concrete problemen van de ouders de verschillen in het psychosomatisch onwelbevinden van de ouders het best verklaren. Hiertoe is een multiple regressie analyse op het psychosomatisch onwelbevinden (blok 6) uitgevoerd waarin alle variabelen uit de blokken $1 \mathrm{t} / \mathrm{m} 5$ als onafhankelijke variabelen zijn ingevoerd.

Alle multiple regressie analyses zijn stapsgewijs uitgevoerd, waarbij de grootte van de partiële correlatiecoëfficiënten de volgorde heeft bepaald waarin de predictoren zijn ingevoerd (Van Knippenberg \& Siero, 1980). Vanwege mogelijke intercorrelaties tussen de predictoren zijn de regressieprocedures stop gezet nadat alle predicto- 
ren mel een significante eigen bijdrage $(p<.01)$ aan de te verklaren variantie in de betreffende afhankelijke variabele in de regressievergelijking waren opgenomen. $O_{p}$ deze wijze zijn nieuwe modellen gevormd waarin telkens een beperkt aantal variabelen is opgenomen die elk een significante eigen bijdrage leveren aan de predictie van de betreffende afhankelijke variabele (volledig verzadigde modellen).

\section{Het copingmodel (schema 6.2)}

Om de rol van coping in het stressproces te bestuderen, is eerst nagegaan of coping iets loevoegt aan de verklaring van de variantie in het psychosomatisch onwelbevinden van de ouders. Hiertoe is een hiërarchische multiple regressie analyse uitgevoerd met het psychosomatisch onwelbevinden als afhankelijke variabele.

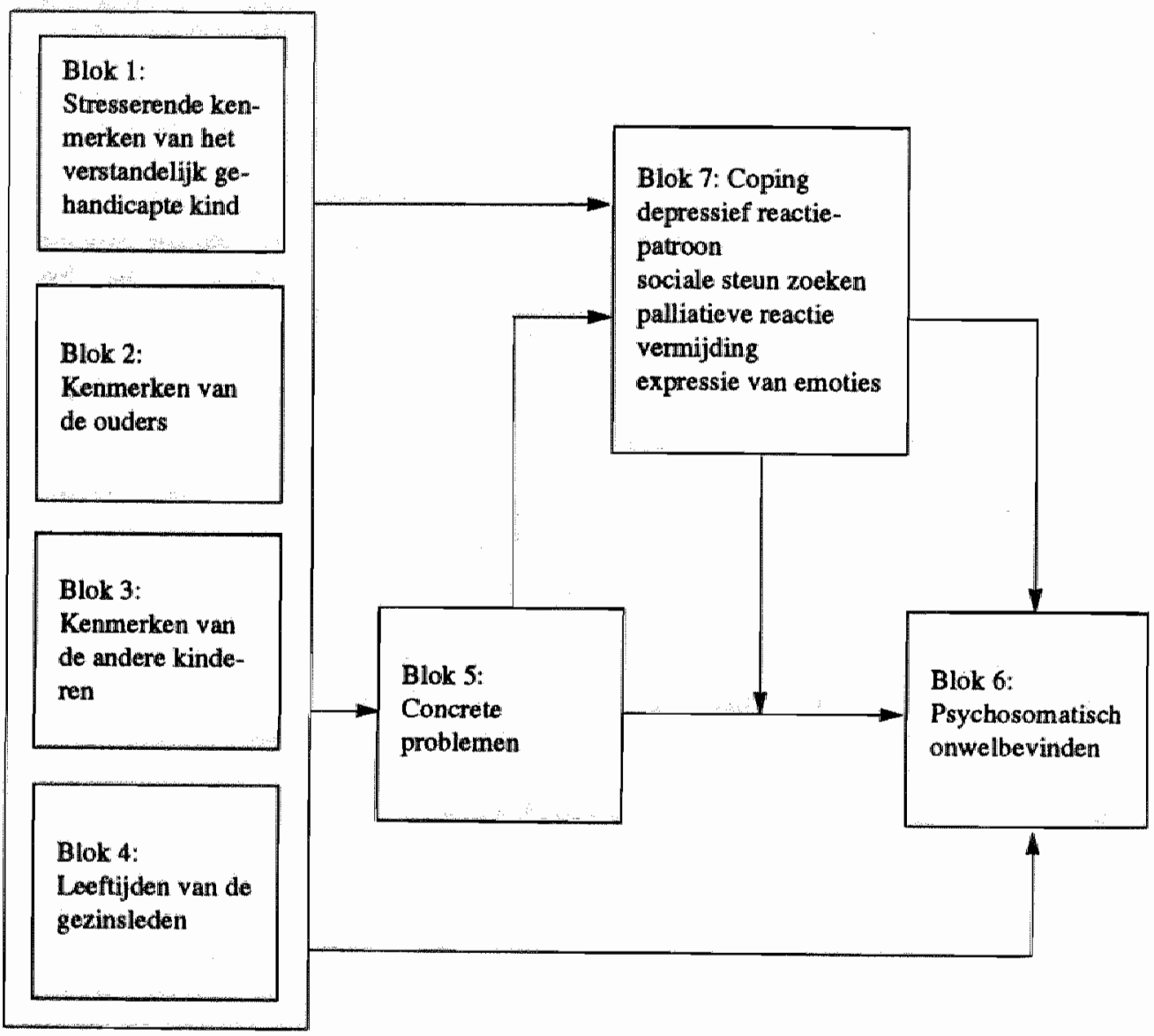

Schema 6.2. Copingmodel ten aanzien van stress bij ouders van een kind met een verstandelijke handicap: meetmodel 
In de eerste stap van de hiërarchische regressie analyse zijn stapsgewijs de determinanten uit het basismodel ingevoerd, in de tweede stap zijn de vijf copingstijlen toegevoegd en in de derde stap de 20 interactietermen van deze copingstijlen met de vier concrete problemen van de ouders. Deze interactietermen zijn berekend door van de oorspronkelijke variabelen het gemiddelde af te trekken. Dit om multicollineariteit tegen te gaan ten gevolge van een sterke samenhang tussen de oorspronkelijke en de interactietermen (Paunonen \& Jackson, 1988). Wanneer het percentage verklaarde variantie in het psychosomatisch onwelbevinden na stap 3 groter is dan na stap 1 (het basismodel), kan geconcludeerd worden dat coping inderdaad een rol speelt in het stressproces van ouders van een verstandelijk gehandicapt kind.

Vervolgens is nagegaan op welke manier(en) de copingstijlen gerelateerd zijn aan het psychosomatisch onwelbevinden van ouders. Hiertoe zijn de standaardpartielle regressiecoëfficiënten, de bêta's, uit de hiërarchische regressie analyse geïnspecteerd.

Ten eerste is nagegaan of coping de auders beschermt tegen psychosomatische klachten wanneer zij concrete problemen ervaren. Wanneer de bêta van éen of meer interactietermen (stap 3) een statistisch significant niveau bereikt, kan worden geconcludeerd dat de betreffende copingstijl een dergelijk modererend effect heeft als blijkt dat ouders met veel concrete problemen meer van de betreffende copingstijl profiteren dan ouders met weinig problemen (zie 2.4).

Ten tweede is nagegaan in hoeverre coping de ouders op een andere, namelijk mediërende wijze beschermt tegen de nadelige gevolgen van de concrete problemen op hun psychosomatisch welbevinden. Van volledige mediatie is sprake wanneer de antecedenten van een bepaalde copingstijl overeenkomen met de determinanten van het psychosomatisch onwelbevinden van de ouders én wanneer deze laatste determinanten hun significante bijdrage aan het onwelbevinden verliezen wanneer de betreffende copingstijl in de analyse wordt betrokken (Baron \& Kenny, 1986).

Om de mediërende rol van coping te onderzoeken, zijn eerst de antecedenten bepaald van die copingstijlen die in de tweede stap van de hiërarchische multiple regressie analyse een significante bijdrage leveren aan de verklaring van het psychosomatisch onwelbevinden van de ouders, dat wil zeggen een statistisch significante bêta hebben. Hiertoe is een stapsgewijze multiple regressie analyse op de betreffende copingstijl uitgevoerd met de variabelen uit de blokken $1 \mathrm{t} / \mathrm{m} 5$ als mogelijke predictoren. Deze regressie(s) is/zijn op dezelfde wijze uitgevoerd als die ten aanzien van het basismodel.

Vervolgens is de hièrarchische multiple regressie analyse op het psychosomatisch onwelbevinden herhaald ter bepaling van de bêta-gewichten van de predictoren, die immers afhangen van de andere in de set opgenomen onafhankelijke variabelen. De determinanten uit het basismodel en de antecedenten van de betreffende copingstijl zijn in stap 1 stapsgewijs ingevoerd, de betreffende copingstijl in stap 2 en de eventuele significante interactie(s) met de concrete problemen in stap 3. Wanneer de determinanten uit het basismodel in deze regressie analyse hun significante eigen 
bijdrage aan de verklaring van het psychosomatisch onwelbevinden verliezen, kan geconcludeerd worden dat de betreffende copingstijl een mediërende functie vervult tussen deze determinanten en het psychosomatisch onwelbevinden van ouders.

Behouden de determinanten uit het basismodel hun significante bijdrage aan de predictie van het welbevinden, dan vormt het gebruik van de betreffende copingstijl een extra probleem voor ouders wannecr deze copingstijl op een negatieve wijze bijdraagt aan hun psychosomatisch welbevinden en een extra steun wanneer deze copingstijl een positieve bijdrage aan hun welbevinden levert.

\section{Het sociale-steunmodel (schema 6.3)}

Bij het sociale-steunmodel is een onderscheid gemaakt tussen structurele en functionele sociale steun.

Bij de analyses van dit model is eerst nagegaan in hoeverre structurele sociale steun een extra bijdrage levert aan de verklaring van de vier concrete problemen van de ouders. Hiertoe is een hiërarchische multiple regressie analyse uitgevoerd op elk van de concrete problemen. Stapsgewijs zijn hierbij telkens de determinanten van deze concrete problemen uit het basismodel in de eerste stap opgenomen en de drie indices voor structurele sociale steun in de tweede. Wanneer het percentage verklaarde variantie in de concrete problemen na stap 2 groter is dan na stap 1 (het basismodel), wordt geconcludeerd dat structurele sociale steun extra informatie geeft.

In het sociale-steunmodel wordt vervolgens verondersteld dat zowel structurelle als functionele sociale steun van belang kan zijn bij de verklaring van het psychosomatisch onwelbevinden van de ouders. De roll van beide soorten sociale steun in de voorspelling van deze afhankelijke variable is in essentie op dezelfde wijze geanalyseerd als de rol van coping in het copingmodel. In plaats van de vijf copingstijlen zijn de zes indices voor sociale steun bestudeerd (zie 6.1.1) alsmede de 24 interacties tussen deze indices en de vier concrete problemen van de ouders.

\subsubsection{Evaluatieve vraagstellingen: Beschrijving van de analyses}

Ter evaluatie van Praktisch Pedagogische Gezinsbegeleiding, Praktische Thuishulp en Weekendopvang zijn vier subvraagstellingen geformuleerd (zie 1.3). De eerste betreft de kenmerken van de gezinnen die de respectievelijke hulpvormen aanvragen.

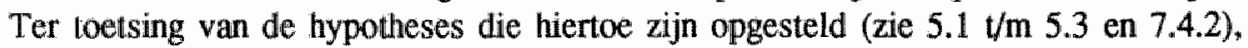
zijn de scores op de voormeting van elk van de achtereenvolgende hulpverleningsgroepen met die van de controlegroep vergeleken. Multivariate variantie analyses (MANOVA's) zijn gebruikt voor zover de hypotheses meerdere samenhangende variabelen binnen éen blok van de stressmodellen betreffen, Student's t-toetsen voor zover de hypotheses é́n afhankelijke variabele betreffen. 
Bllok 8a:

Structurele so ciale steun

burgerlijke staat totaal aantal steungevenden lidmatschap geloofsgemeenschap

\section{Blok 1:}

Stresserende kenmerken van het verstandelijk gehandicapte kind

Bilok 2:

Kenmerken van de ouders

Blok 3:

Kenmerken van de andere kinderen

Blok 4:

Leeftijden van de gezinsleden
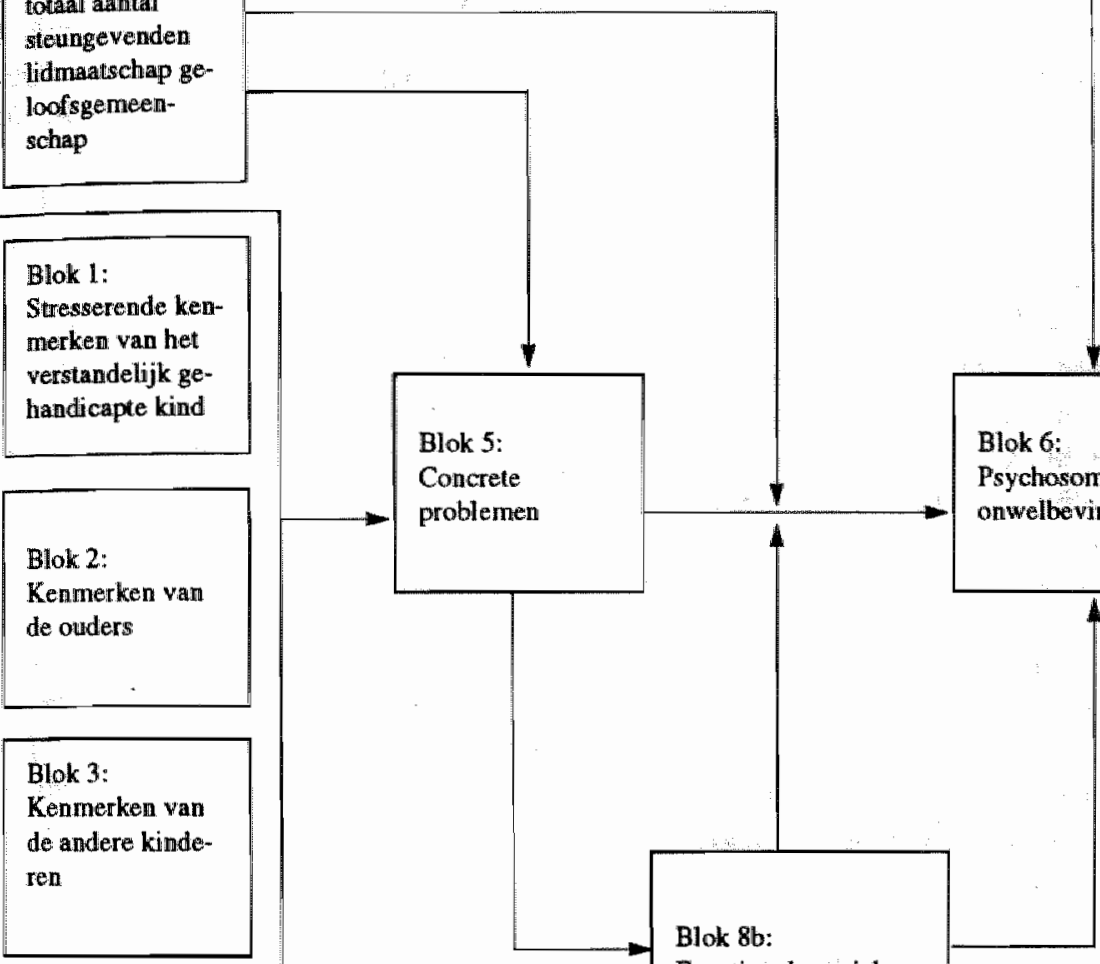

Blok 5:

Concrete problemen

Blok 6:

Psychosomatisch onwelbevinden
Blok 8b:

Functionele sociale steun partnerstewn steun uit geloof sociale isolatie

Schema 6.3. Sociale-steunmodel ten aanzien van stress bij ouders van een kind met een verstandelijke handicap: meetmodel

Wanneer er verschillen tussen de achtereenvolgende hulpverleningsgroepen en de controlegroep worden aangetroffen, is vervolgens nagegaan of deze effecten van het wel of niet aanvragen van hulp tot stand zijn gekomen via (a) demografische kenmerken, zoals het geslacht van het gehandicapte kind, de leeftijd van de gezinnen en de burgerlijke staat van de ouders, of (b) de determinanten van de betreffende variabele die uit de toetsingen van de stressmodellen naar voren zijn gekomen. 
Hiertoe zijn uni- respectievelijk multivariate covariantie analyses ((M)ANCOVA's) uitgevoerd op de scores van de betreffende variabelen, met de in (a) respectievelijk (b) genoemde variabelen als covariaten.

De tweede subvraagstelling heeft betrekking op de hulpvragen van ouders die zich tot PPG wenden respectievelijk op de redenen van ouders om zich bij PT of WO aan te melden. Ouders met een zelfde hulpvraag of reden voor aanmelding zijn in eén subgroep ondergebracht zodat per hulpvorm meerdere subgroepen zijn ontstaan. Om na te gaan of er binnen de totale hulpverleningsgroep verschillen in belasting bestaan die te maken hebben met de hulpvragen van de ouders c.q. hun redenen voor aanmelding, is elke subgroep vergeleken met alle overige gezinnen die zich bij de betreffende hulpvorm hebben aangemeld wat de stress van de ouders en de determinanten daarvan betreft. Bij deze analyses zijn alle variabelen uit de blokken $1 \mathrm{t} / \mathrm{m} 8$ van de stressmodellen betrokken. MANOVA's worden gebruikt voor zover de vergelijkingen bloksgewijs plaatsvinden en meerdere samenhangende variabelen binnen tên blok betreffen. Vergelijkingen die eén afhankelijke variabele betreffen, zijn met Student's t-toetsen uitgevoerd voor zover de waarde van de variabele op interval nivo ligt en met chi $^{2}$-toetsen voor zover de waarde op ordinaal of nominaal nivo ligt.

Ten aanzien van de effecten van Praktisch Pedagogische Gezinsbegeleiding, Praktische Thuishulp en Weekendopvang, de derde subvraagstelling, zijn eveneens hypotheses opgesteld (zie $5.1 \mathrm{t} / \mathrm{m} 5.3$ en 7.4.2). In drie analyse-rondes is nagegaan welke inwloed de hulpverlening op de afhankelijke variabelen in deze hypotheses heeft. Deze drie analyse-rondes worden zowel gebruikt om de effecten van de achtereenwolgende hulpvormen op de totale hulpverleningsgroep te bepalen als om de differentiele effecten per subgroep te kunnen bepalen.

In de eerste analyse-ronde is binnen de controle- en de hulpverleningsgroepen nagegaan of er tussen de voor- en de nameting veranderingen zijn opgetreden in de variabelen waarop de hypotheses betrekking hebben. Hiertoe zijn MANOVA's op de verschilscores tussen de voor- en de nameting gebruikt voor zover de hypotheses meerdere afhankelijke variabelen binnen én blok betreffen en gepaarde Student's ttoetsen zijn zover de hypotheses én afhankelijke variabele betreffen.

Analyses van verschilscores binnen één groep bieden in het algemeen weinig mogelijkheden om de eventueel geconstateerde veranderingen eenduidig aan de interventie toe te schrijwen, vanwege statistische regressie van de scores naar het gemiddelde, maturatie of andere bedreigingen voor de inteme validiteit (Cook \& Campbell, 1979). Ter toetsing van de effecthypotheses zijn daarom in de tweede analyse-ronde de achtereenvolgende hulpverleningsgroepen direct met de controlegroep vergeleken. Hiertoe zijin (M)ANCOVA's op de scores in de nameting uitgevoerd waarbij de betreffende scores in de voormeting als covariaten zijn opgenomen. Deze (M)ANCOVA"s zijn uitgevoerd nadat gecontroleerd was voor de parallelliteit en de lineariteit van de regressielijnen in de controle- en de achtereenvolgende hulpverleningsgroepen. 
In de derde analyse-ronde is tenslotte nagegaan in hoeverre de achtereenvolgende hulpverleningsgroepen na een jaar hulp nog van de controlegroep zijn te onderscheiden. Hierbij zijn alleen gegevens uit de nameting betrokken, zonder correctie voor initiële verschillen. De scores van de hulpverleningsgroepen zijn met die van de controlegroep vergeleken, met behulp van MANOVA's respectievelijk Student's ttoetsen. Evenals in de voormeting is ook na een jaar hulpverlening voor elk van de hulpverleningsgroepen nagegaan of de geconstateerde verschillen in de nameting door demografische kenmerken of door de determinanten uit de stressmodellen worden gemedieerd.

De vierde subvraagstelling betreft tenslotte de oordelen van de ouders over de vormgeving en de inhoud van de hulp die zij ontvangen (hebben) alsmede hun algemene satisfactie met de hulp. Voor zover de oordelen enige variatie te zien geven, is getracht na te gaan welke ouders zich meer en welke ouders zich minder positief uitlaten over PPG, PT respectievelijk WO. 


\section{Resultaten I: Toetsing van de stressmodellen}

In hoofdstuk 3 zijn het basismodel, het copingmodel en het sociale-steunmodel opgesteld ter verklaring van de verschillen in stress tussen ouders van een kind met een verstandelijke handicap. In het onderhavige hoofdstuk worden de resultaten gepresenteerd van de analyses die zijn uitgevoerd om na te gaan in hoeverre de empirie deze theoretische modellen ondersteunt. De resultaten worden in $7.1 \mathrm{t} / \mathrm{m} 7.3$ per model weergegeven en in 7.4.1 samengevat. Op basis van deze resultaten worden in 7.4.2 hypotheses opgesteld ten aanzien van de evaluatie van de drie hulpvormen, in aanvulling op de hypotheses die zijn opgesteld naar aanleiding van de beschrijvingen van deze hulpvormen $(5.1 \mathrm{t} / \mathrm{m} 5.3)$.

Voor een beschrijving van de 181 ouders wier gegevens bij deze analyses zijn gebruikt, wordt verwezen naar bijlage A, tabel 5 waarin van alle variabelen de gemiddelden en standaarddeviaties zijn opgenomen.

\subsection{Het basismodel (schema 6.1)}

De analyses ter bepaling van de determinanten van het psychosomatisch onwelbevinden van ouders vonden in drie stappen plaats (zie 6.3.1). Paragraaf 7.1.1 bevat de resultaten van de eerste stap, betreffende de vraag welke potentieel stressvolle kenmerken van het verstandelijk gehandicapte kind werkelijk bijdragen aan de concrete problemen van ouders (blok $1 \rightarrow$ blok 5). Paragraaf 7.1.2 geeft de resultaten weer van de tweede stap, betreffende de wijze waarop de stresserende kenmerken van het gehandicapte kind, de kenmerken van de ouders en de andere kinderen in het gezin en de leeftijden van de gezinsleden in hun onderlinge samenhang gerelateerd zijn aan de concrete problemen van ouders (blok $1 \mathrm{t} / \mathrm{m} 4 \rightarrow$ blok 5). Paragraaf 7.1.3 presenteert de resultaten van de laatste stap die betrekking heeft op de relaties tussen alle tot nog toe genoemde variabelen en het psychosomatisch onwelbevinden van ouders (blok $1 \mathrm{t} / \mathrm{m} 4 \rightarrow$ blok $5 \rightarrow$ blok 6 ). 
Tabel 7.1

Intercorrelaties tussen de potentieel stressvolle kenmerken van het verstandelijk gehandicapte kind, blok $1(n=181)$

\begin{tabular}{lllllllllll}
\hline Blok 1: Kenmerken van & 2 & 3 & 4 & 5 & 6 & 7 & 8 & 9 & 10 & 11
\end{tabular}

bet werstandelijk ge-

handicapte kind

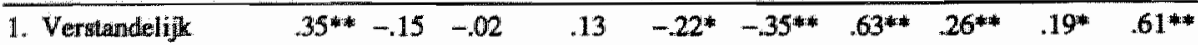
niveau van

functioneren

2. Lichumelijke $\quad-\begin{array}{lllllllll}-.16 & -.07 & -.01 & -.32^{* * *} & -.13 & .46^{* *} & .28^{* *} & .15 & .51 * *\end{array}$ gezondheid

3. Kan zichzelf niet $\quad-\quad .45^{* *} \quad .40^{* *} \quad .26^{* *} \quad .22^{* *}-.33^{* *}-.19 * \quad-.28^{* *}-.29 * *$ bezighouden

4. Extravert gedrag

5. Aandichtwragend gedrag:

6. Eet-en slaapproblemen

7. Introvert gedrag

8. Sociale vaardigheden

9. Sociale gerichtheid

10. Kwaliteit van het contact birnen het gezin

11. Zelfredzaamheid

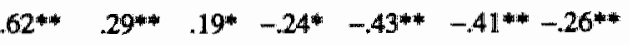

$\begin{array}{llllllll}- & .05 & .02 & -.02 & -.06 & -.06 & -.01\end{array}$

$-.23 *-.36 * *-.34 * *-.25 * *-.43 * *$

$-\quad-54 * *-.46^{* *}-.30 * *-.36 * *$

$-.62 * 0.41 * * .75^{* *}$

- $.55^{* *} .45^{* *}$

$*$ p<.01, twee-zijdig. ${ }^{*}$ * $p<, 001$, twee-zijdig.

Tabel 7.2

Pearson correlaties tussen de potentieel stressvolle kenmerken van het verstandelijk gehandicapte kind, blok 1 , en de concrete problemen van de ouders, blok 5 ( $n=181)$

Blok 5: Concrete problemen

Blok 1: Kenmerken van het verstandelijk gehandicapte kind

\begin{tabular}{llll}
\hline $\begin{array}{l}\text { Gezinswer- } \\
\text { storing }\end{array}$ & $\begin{array}{l}\text { Praktische } \\
\text { drak }\end{array}$ & $\begin{array}{l}\text { Problemen } \\
\text { m.b.t. de } \\
\text { partner }\end{array}$ & $\begin{array}{l}\text { Zorgen over de } \\
\text { ontwikkeling } \\
\text { van de andere } \\
\text { kinderen }\end{array}$
\end{tabular}

1. Verstandelijk niveau van functioneren

2. Lichamelijke gezondheid

3. Kan zichzelf niet bezighouden

4. Extrivert gedrag

5. Aandlachtvragend gedrag

6. Eet- en slaapproblemen

7. Introvert gedrag

8. Sociale waardigheden

9. Sociale gerichtheid

10. Kwaliteit van het contact binnen het gezin

11. Zelfredzanmheid

$-.11$

$-.21 *$

$-.28^{* *}$

$41^{\text {m. }}$

$.57 * *$

$48 * *$

$.44^{* * *}$

$.23 *$

$-32 * *$

$-.43^{* *}$

$-.39 * *$

$-.26 * *$

$-.23 *$

$-.22 *$

$-.33 * *$
$-.12$

$-.04$

.31 **

$-32 * *$

$-.26 * *$

$.27 * *$

$.24^{*}$

$.25 * *$

$.36^{* *}$

.17

$-.25 *$

$-.20 *$

$-.18$

$-.27 * *$

$-.14$

${ }^{*} \mathrm{p}<.01$, twee-zijdig. ${ }^{* *} \mathrm{p}<.001$, twee-zijdig. 


\subsection{Stresserende kenmerken van het verstandelijk gehandicapte kind}

In blok 1 van schema 6.1 zijn twaalf potentieel stresswolle kenmerken van het verstandelijk gehandicapte kind genoemd: het geslacht, het verstandelijk niveau van functioneren, de lichamelijke gezondheid, vijf gedragsproblemen (het kind kan zichzelf niet bezighouden, extravert gedrag, aandachtvragend gedrag, eet- en slaapproblemen en introvert gedrag), drie indices voor sociale redzaamheid (sociale vaardigheden, sociale gerichtheid en de kwaliteit van het contact binnen het gezin) en de zelfredzaamheid van het kind.

Tabel 7.1 laat zien dat er hoge intercorrelaties zijn tussen elf van deze potentieel stressvolle kenmerken. Deze clustering speelt naar verwachting door in de correlaties tussen deze kenmerken en de concrete problemen van ouders. Uit de correlatiematrix in tabel 7.2 is dan ook niet eenduidig af te leiden welke kenmerken van het verstandelijk gehandicapte kind van doorslaggevend belang zijn bij de problemen van de ouders. Uit Student's t-toetsen blijkt overigens dat het twaalfde kenmerk, het geslacht van het gehandicapte kind, met geen van de overige kenmerken samenhangt noch met de concrete problemen van ouders.

Om het aantal potentieel stressvolle kenmerken van het gehandicapte kind terug te brengen tot een geringer aantal (clusters van) kenmerken die daadwerkelijk gerelateerd zijn én of meer concrete problemen, is per concreet probleem én multiple discriminant analyse uitgevoerd. Met deze techniek zoekt men in het algemeen naar combinaties van onafhankelijke variabelen die maximaal discrimineren tussen groepen van respondenten. De ouders zijn voor elk van de vier discriminant analyses in drie groepen ingedeeld:

(1) een groep ouders die op dat specifieke gebied weinig problemen ervaart en een waarde op de schaal voor het betreffende concrete probleem heeft tussen de laagste schaalwaarde en de gemiddelde schaalwaarde;

(2) een groep ouders die op dat specifieke gebied in enige mate problemen ervaart en een schaalwaarde heeft tussen de gemiddelde waarde en dit gemiddelle plus én standaarddeviatie; en

(3) een groep ouders die op dat specifieke gebied veel problemen ervaart en een schaalwaarde heeft die hoger is dan de gemiddelde waarde plus én standaarddeviatie. (N.B. De verdelingen ten aanzien van de concrete problemen zijn scheef, met weinig respondenten die hoog scoren, i.c. veel problemen hebben.)

In elke discriminant anallyse zijn twee discriminantfuncties berekend (zie Pedhazur, 1982). Deze zijn op te vatten als nieuwe variabelen die bestaan uit een gewogen lineaire combinatie van de oorspronkelijke onafhankelijke variabelen, i.c. de kenmerken van het gehandicapte kind, die een maximaal onderscheid maken tussen de drie bij elk concreet probleem genoemde groepen van ouders.

Bij de probleemgebieden "praktische druk" en "problemen met betrekking tot de partner" is alleen de eerste discriminantfunctie significant. Bij de probleemgebieden "gezinsverstoring" en "zorgen over de ontwikkeling van de andere kinderen" bereiken 
beide functies een significant niveau. Bij beide laatstgenoemde probleemgebieden zijn de tweede functies echter buiten beschouwing gebleven omdat deze slechts een gering onderscheidend vermogen bleken te hebben: de variantie tussen de groepen was bij deze functies gering in relatie tot de variantie binnen de groepen, hetgeen tot uitdrukking kwam in kleine eigenwaarden (respectievelijk .18 en .15).

Tabel 7.3

Pearson correlaties tussen de kenmerken van het verstandelijk gehandicapte kind, blok 1 , en de discriminantfuncties ten aanzien van de concrete problemen, blok 5 $(n=181)$

Blok 5: Concrete problemen

Blok 1: Kenmerken wan thet verstandelijk gehandicapte kind

\begin{tabular}{llll}
\hline Gezinswer- & Praktische & Problemen & Zorgen over \\
storing. & druk & m.b.t. de & de ontwik- \\
& & partner & keling van \\
& & de andere \\
& & & kinderen
\end{tabular}

\begin{tabular}{lrrrr}
\hline 1. Geslacht & .11 & -.02 & -.004 & .06 \\
2. Verstandelijk niveau & -.008 & -.29 & -.17 & -.06 \\
$\quad$ van functioneren & & & & \\
3. Lichanelijke gezondheid & -.22 & -.26 & -.74 & -.50 \\
4. Kan zichzolf niet bezighouden & .35 & .45 & .27 & .20 \\
5. Extravert gedrag & .65 & .47 & .38 & .67 \\
6. Aandachtwragend gedrag & .48 & .56 & .37 & .30 \\
7. Eet- en slarapproblemen & .43 & .52 & .60 & .49 \\
8. Introvert gedrag & .22 & .45 & .09 & .12 \\
9. Sociale vardigheden & -.30 & -.62 & -.36 & -.30 \\
10. Sociale gerichtheid & -.50 & -.35 & -.27 & -.42 \\
11. Kwaliteit van het contact & -.53 & -.29 & -.23 & -.47 \\
binnen het gezin & & & & \\
12. Zellfredzalamheid & -.19 & -.47 & -.39 & -.25 \\
\end{tabular}

De correlaties tussen de oorspronkelijke onafhankelijke variabelen en de discriminantfuncties geven inzicht in de vraag welke kenmerken van het gehandicapte kind bijdragen aan de verschillen in de emst van de vier concrete problemen. Tabel 7.3 geeft deze correlaties weer. Voor de interpretatie van de richting van deze correlaties is het van belang te weten dat de gemiddelden van de drie groepen ouders die bij elk concreet probleem zijn onderscheiden, aangeven dat een hogere score op de discriminantfunctie een grotere mate van problemen aanduidt.

Op basis van de correlaties in tabel 7.3 zijn vier clusters van kenmerken van het gehandicapte kind gevormd die gerelateerd zijn aan de concrete problemen van ouders. Voor drie van deze clusters zijn nieuwe schalen geconstrueerd door ongewogen sommatie en middeling van de scores op de oorspronkelijke schalen voor deze kenmerken (zie 6.1.1): 
(1) Gedragsprobllemen: extravert gedrag, aandachtvragend gedrag en eet- en slaapproblemen. Gedragsproblemen spelen een rol bij alle vier concrete problemen (zie tabel 7.3).

(2) Sociale redzaamheid: sociale gerichtheid en kwaliteit van het contact binnen thet gezin. Een geringe sociale redzaamheid is vooral geassocieerd met de gezinsverstoring en de bezorgdheid van de ouders over de ontwikkeling van hun andere kinderen.

(3) Sociale vaardigheden en zelfredzaamheid. Deze vaardigheden zijn gerelateerd aan het verstandelijk niveau van functioneren, maar het niveau op zich is niet in deze schaal opgenomen, omdat deze variabele niet in belangrijke mate correleert met de discriminantfuncties (zie tabel 7.3). Het verstandelijke niveau van functioneren correleert wel hoog met de nieuw geconstrueerde schaal: $r=65$; $p<.001$, een-zijdig. Geringe sociale vaardigheden en een beperkte zelfredzaamheid spelen vooral een rol bij de praktische druk die ouders ervaren en bij de problemen met betrekking tot de partner.

Het vierde kenmerk, dat in hoge mate gerelateerd is aan de problemen met betrekking tot de partner, is de lichamelijke gezondheid van het gehandicapte kind. De schaal waarmee deze variabelen gemeten is, bestaat uit meerdere indices (zie 6.1.1) en is ongewijzigd gehandhaafd.

De twaalf oorspronkelijke potentieel stressvolle kenmerken van het verstandelijk gehandicapte kind zijn gereduceerd tot vier clusters van kenmerken die gerelateerd zijn aan éen of meer concrete problemen van ouders. Deze worden in de verdere analyses aangeduid als "de stresserende kenmerken van het verstandelijk gehandicapte kind". Het geslacht van het kind, zijn of haar verstandelijk niveau van functioneren en de gedragsproblemen "het verstandelijk gehandicapte kind kan zichzelf niet bezighouden" en "introvert gedrag" worden niet bij de verdere analyses betrokken, orndat deze kenmerken nauwelijks van belang zijn in het onderscheid tussen ouders die veel, matig of weinig concrete problemen ervaren.

\subsubsection{Predictie van de concrete problemen van ouders}

In de tweede stap van de analyse van het basismodel is nagegaan in hoeverre de stresserende kenmerken van het verstandelijk gehandicapte kind, kenmerken van de ouders, kenmerken van de andere kinderen en de leeftijden van de gezinsleden op directe wijze gerelateerd zijn aan de concrete problemen van de ouders. Tabel 7.4 geeft een overzicht van de correlaties tussen de concrete problemen van de ouders (blok 5) en de variabelen in blok $1 \mathrm{t} / \mathrm{m} 4$. Bijlage $C$, tabel 1 , geeft een overzicht van de intercorrelaties tussen de variabelen in de blokken $1 \mathrm{t} / \mathrm{m} 4$.

Per concreet probleem is een stapsgewijze multiple regressie analyse uitgevoerd (zie voor een beschrijving 6.3.1). De resultaten van deze vier multiple regressie analyses staan vermeld in tabel 7.5. De bêta's in tabel 7.5 zijn de standaardpartiële regressiecoëfficiënten uit de nieuwe modellen waarin alleen die onafhankelijke variabelen zijn opgenomen die een significante eigen bijdrage leveren aan de te verklaren 
variantie in het betreffende concrete probleem, onder constanthouding van de overige in de regressievergelijking opgenomen predictoren.

\section{Tabel 7.4}

Pearson correlaties tussen de variabelen uit de blokken $14 \mathrm{~m} 4$ en de concrete problemen en het psychosomatisch onwelbevinden, blok 5 en $6(n=181)$

Blok 5: Concrete problemen

Blok 6: Psy-

chosomatisch

onwelbevinden

Blok $1 \mathrm{tm} 4$

\begin{tabular}{|c|c|c|c|c|}
\hline $\begin{array}{l}\text { Gezins- } \\
\text { verstlo- } \\
\text { ring }\end{array}$ & $\begin{array}{l}\text { Praktische } \\
\text { druk }\end{array}$ & $\begin{array}{l}\text { Problemen } \\
\text { mb.t. de } \\
\text { partner }\end{array}$ & $\begin{array}{l}\text { Zorgen ower } \\
\text { de ontwikke- } \\
\text { ling wan de } \\
\text { andere kinderen }\end{array}$ & $\begin{array}{l}\text { Psychosomatisch } \\
\text { onwelbevinden }\end{array}$ \\
\hline
\end{tabular}

Blok 1: Stresserende kenmerken van het verstandelijk gehandicapte kind

$\begin{array}{lllll}\text { 1. Gedragsproblemen } & .66^{* *} & .48^{* *} & .37^{* *} & .45^{* * *}\end{array}$

2. Sociale redzaamheid $\quad-.47 * * \quad-.29 * * \quad-.22 * \quad-.37 * *$

$-.30 * * \quad-.40^{* * *}$

$-30 * *$

$-.21 *$

$-.28 * *$

en zelfredzaamheid

4. Lichamelijke gezond-

$-.28 *-.23 *$

$-.32 * *$

$-.26 * *$

.08

heid

Blok 2: Kenmerken van de ouders

$\begin{array}{llllll}\text { 5. Sociale klasse } & .09 & .18 & .15 & .13 & -.09 \\ \text { 6. Opleidingsniveau moeder } & .07 & .19^{*} & .12 & .04 & -.16 \\ \text { 7. Opleidingsniveau vader } & .05 & .20^{*} & .19 & .04 & -.16 \\ \text { 8. Zelfwaardering } & -.35^{* *} & -.25^{* *} & -.30^{* * *} & -.32^{* * *} & -.61 * *\end{array}$

Blok 3: Kenmerken van de andere kinderen

9. Aantal andere kinderen $\quad-.22 * \quad-.07$

10. Plaats k.v.h. in de $\quad .15 \quad .01$

$.01 \quad-.09$

-.09
-.10

$-.08$ kinderrij

11. Relatie k.w.h. met $-.36^{\text {m** }} \quad-.17$

$-.12$

$-.29 * 4$

$-13$ broer(s) en/of zus(sen)

Blok 4: Leeftijden van de gezinsleden
12. Leeftijd k.v.h.
$-.23^{*} \quad-.19^{*}$
$-.12$
$-.10$
$-.11$
13. Leeftijd moeder
$-.31 * *-.17$
$-.10$
$-.12$
$-.10$
14. Leeftijd vader
$-.21 * \quad-.13$
$-.03$
$-.13$
$-.03$
15. Gemiddelde leeftijd
$-.29 * * \quad-.17$
$-.10$
$-.04$
$-.08$
andere kinderen

Blok 6: Prychosomatisch onwelbevinden

16. Psychosomatisch

$.61^{* *}$ onwelbevinden

Noot. K.v.h. = kind met een verstandelijke handicap.

*p<,01, twee-zijdig. ** $\mathrm{p}<$.001, twee-zijdig. 
Uit tabel 7.5 blijkt dat drie soorten variabelen van belang zijn voor de verklaring van de verschillen in de emst van de concrete problemen van ouders. Ten eerste zijn de vier stresserende kenmerken van het verstandelijk gehandicapte kind in hoge mate geassocieerd met de concrete problemen. Naarmate het gehandicapte kind meer gedragsproblemen heeft, een geringere sociale redzaamheid, minder sociale vaardigheden, een meer beperkte zelfredzaamheid en een slechtere lichamelijke gezondheid, ervaren de ouders meer concrete problemen. De multiple regressie resultaten komen wat de aard van deze relaties betreft grotendeels overeen met de bevindingen uit de multiple discriminant anallyses (zie 7.1.1).

\section{Tabel 7.5}

Resultaten van de vier stapsgewijze multiple regressie analyses op de concrete problemen van de ouders $(n=181)$

\begin{tabular}{|c|c|c|c|c|c|c|c|c|c|}
\hline Stap & Variabele & $\mathbb{R}$ & $\mathbf{R}^{2}$ & $\mathrm{R}^{2}$-change & $F\left(R^{2}\right.$-change $)$ & d.f. & $\mathrm{p}<$ & B & $\mathbf{r}$ \\
\hline \multicolumn{10}{|c|}{ Gezinsverstoring } \\
\hline 1. & Gedragsproblemen & .64 & .41 & .41 & $122.0 !$ & 1,179 & .001 & .51 & .66 \\
\hline 2. & Sociale redzaamheid & .68 & .47 & .06 & 20.37 & 2,178 & .001 & -.24 & -.47 \\
\hline 3. & Zelfwaardering & .71 & .50 & .03 & 12.11 & 3.177 & .001 & -19 & -.35 \\
\hline \multicolumn{10}{|c|}{ Praktische druk } \\
\hline 1. & Gedragsproblemen & .46 & .21 & .21 & 48.70 & 1,179 & .001 & .36 & .48 \\
\hline 2. & $\begin{array}{l}\text { Sociale vaardigheden en } \\
\text { zelfredzaamheid }\end{array}$ & .55 & .30 & .09 & 21.90 & 2,178 & .001 & -.27 & -.40 \\
\hline 3. & Opleidingsniveau vader & .57 & .33 & .03 & 7.50 & 3,177 & .01 & .19 & .20 \\
\hline 4. & Zelfwaardering & .60 & .36 & .03 & 7.53 & 4,176 & .01 & -.17 & -.25 \\
\hline \multicolumn{10}{|c|}{ Problemen m.b.t. de partner } \\
\hline 1. & Gedragsprobiemen & .35 & .12 & .12 & 24.89 & 1,179 & .001 & .28 & .37 \\
\hline 2. & $\begin{array}{l}\text { Lichamelijke } \\
\text { gezondheid }\end{array}$ & .44 & .19 & .07 & 15.12 & 2,178 & .001 & -.22 & -.32 \\
\hline 3. & Zelfwaardering & .48 & .23 & .04 & 8.59 & 3,177 & .01 & -.22 & -30 \\
\hline 4. & Opleidingsniveau vader & .52 & .27 & .04 & 9.28 & 4,176 & .01 & .20 & .19 \\
\hline \multicolumn{10}{|c|}{ Zorgen over de ontwikkeling van de andere kinderen } \\
\hline 1. & Gedragsproblemen & .41 & .17 & .17 & 36.35 & $\mathbb{1}, 179$ & .001 & .29 & .45 \\
\hline 2. & Zelfwaardering & .47 & .22 & .05 & 11.80 & 2,178 & .001 & -.21 & -.32 \\
\hline 3. & Sociale redzaamheid & .51 & .26 & .04 & 8.92 & 3,177 & .01 & -.21 & -37 \\
\hline
\end{tabular}

Ten tweede heeft een geringe zelfwaardering van de ouders negatieve consequenties bij alle vier probleemgebieden. Ouders ervaren op alle onderzochte terreinen meer concrete problemen naarmate zij minder zelfwaardering hebben. Een verbetering in hun zelfwaardering zal een aanzienlijke reductie in hun concrete problemen tot gevolg hebben, ook wanneer hun situatie voor het overige niet verbetert.

De stresserende kenmerken van het gehandicapte kind en de zelfwaardering van ouders zijn niet alleen op directe wijze gerelateerd aan de concrete problemen. Dit is te zien aan het verschil tussen de oorspronkelijke correlaties van de genoemde predictoren met de concrete problemen en de beta's die alleen de directe relaties tussen de predictoren en de problemen weergeven (in tabel 7.5 zijn beide parameters opgenomen). Er blijkt een voor de praktijk van de hulpverlening interessante overlap 
te bestaan tussen cén van de stresserende kenmerken van het gehandicapte kind, namelijk zijn of haar gedragsproblemen, en de zelfwaardering van ouders ( $\mathbb{r}=-.24$; p<.001, twee-zijdig; zie bijlage $C_{\text {, tabel }} 1$ ). Deze overlap houdt in dat een afname van één van beide predictoren, onder de assumpties van het basismodel, niet alleen een directe afname van de concrete problemen tot gevolg heeft, maar ook een indirecte extra daling, namelijk via een afname van de andere predictor.

De derde variabele, die vooral van belang is voor de verklaring van de praktische druk en de problemen met betrekking tot de partner, is het opleidingsniveau van de vaders. Ongeacht de stresserende kenmerken van het verstandelijk gehandicapte kind en de zelfwaardering van de ouders hebben ouders met een hogere opleiding meer problemen met hun partner en ervaren zij meer praktische druk dan ouders met een lager niveau van opleiding.

De overige variabelen uit de blokken $1 \mathrm{t} / \mathrm{m} 4$ zijn niet op directe wijze gerelateerd aan de concrete problemen van ouders. Dit betekent niet dat ze in het geheel geen rol spelen in het ontstaan of verergeren van deze problemen. Zij zijn alleen niet van doorslaggevend belang omdat hun relaties met de concrete problemen zijn af te leiden uit hun samenhangen met de stresserende kenmerken van het gehandicapte kind, de zelfwaardering van de ouders en in mindere mate het opleidingsniveau van de ouders (zie bijlage C, tabel 1 voor deze intercorrelaties).

\subsubsection{Predictie wan het psychosomatisch onwelbevinden wan ouders}

Als laatste stap in de exploratie van het basismodel is nagegaan in hoeverre het psychosomatisch onwelbevinden van de ouders afhankelijk is van de stresserende kenmerken van het gehandicapte kind, de kenmerken van de ouders en de andere kinderen, de leeftijden van de gezinsleden en de concrete problemen van ouders. Voor de correlaties tussen deze variabelen wordt verwezen naar tabel 7.4. Er is eén stapsgewijze multiple regressie analyse uitgevoerd met het psychosomatisch onwelbevinden van de ouders als afhankelijke variabele en alle variabelen uit de blokken $1 \mathrm{t} / \mathrm{m} 5$ als mogelijke predictoren. De resultaten van deze regressie analyse staan in tabel 7.6. De bêta's in deze tabel behoren bij het nieuwe, beperkte model waarin alleen die onafhankelijke variabelen zijn opgenomen die een significante eigen bijdrage $(p<.01)$ leveren aan het psychosomatisch onwelbevinden (zie 6.3.1).

Tabel 7.6

Resultaten van de stapsgewijze multiple regressie analyse op het psychosomatisch onwelbevinden $(n=181)$

\begin{tabular}{lllllllllr}
\hline Stap & Variabele & $\mathrm{R}$ & $\mathrm{R}^{2}$ & $\mathrm{R}^{2}$-change & $\mathrm{F}\left(\mathrm{R}^{2}\right.$-change $)$ & $\mathrm{d} . \mathrm{f}$. & $\mathrm{p}<$ & $\mathrm{B}$ & $\mathrm{r}$ \\
\hline 1. & Gezinsverstoring & .58 & .34 & .34 & 91.91 & 1,179 & .001 & .45 & .61 \\
2. & Zelfwaardering & .71 & .50 & .17 & 59.47 & 2,178 & .001 & -.41 & -.61 \\
3. & Opleidingsniveau & .72 & .52 & .02 & 8.23 & 3,177 & .01 & -.15 & -.16 \\
& moeder & & & & & & & &
\end{tabular}


Schema 7.1 bevat het nieuwe gereduceerde model ten aanzien van de stress van ouders van een kind met een verstandelijke handicap, dat gebaseerd is op de toetsingen van de veronderstelde samenhangen uit het oorspronkelijke, op theoretische inzichiten gefündeerde basismodel uit schema 6.1.

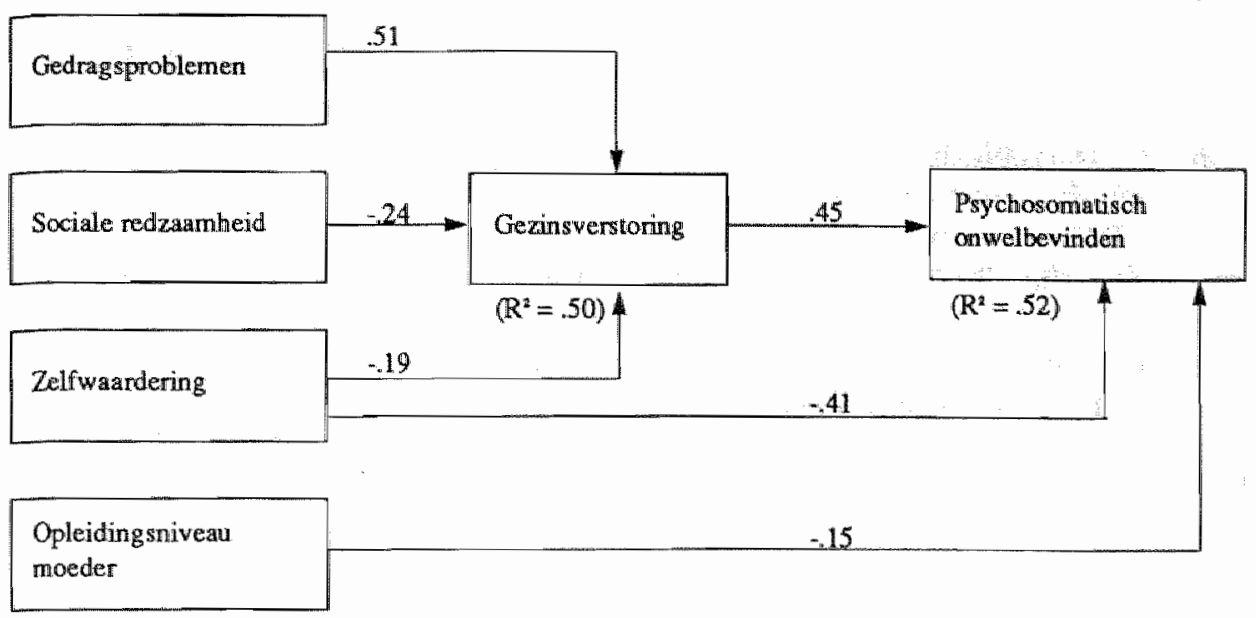

Schema 7.1. Basismodel ten aanzien van stress bij ouders van een kind met een verstandelijke handicap: beperkt model

Uit schema 7.1 wordt duidelijk dat het psychosomatisch welbevinden van ouders ten eerste afhankelijk is van de mate van gezinsverstoring die zij ervaren. De drie andere concrete problemen, praktische druk, problemen met betrekking tot de partner en zorgen over de ontwikkeling van de andere kinderen in het gezin, zijn onder de assumpties van het basismodel niet op directe wijze gerelateerd aan het welbevinden van ouders. Dit betekent niet dat deze problemen in het geheel geen relatie met het welbevinden hebben: ouders voelen zich lichamelijk en geestelijk slechter naarmate zij meer problemen ervaren op elk van de vier onderzochte terreinen (zie tabel 7.4). Gezien de overlap tussen de vier concrete problemen en gezien het feit dat gezinsverstoring het meest algemene probleemgebied is (zie ook 6.1.1), hangt dit probleem het meest met het psychosomatisch onwelbevinden samen en wordt het als eerste in de regressievergelijking opgenomen, daarmee de statistische invloed van de overige problemen tot onder een significant niveau reducerend.

Ten tweede is een lage zelfwaardering van ouders direct gerelateerd aan psychosomatische klachten. Bovendien speelt een geringe zelfwaardering een rol in de gezinsverstoring die ouders ervaren, hetgeen, onder de assumpties van het basismodel, op indirecte wijze bijdraagt aan hun psychosomatissch onwelbevinden.

Ten derde draagt het opleidingsniveau van moeder onder de aannames van het basismodel in geringe mate bij aan het psychosomatisch onwelbevinden: ouders met 
cen lager opleidingsniveau hebben onder overigens gelijk blijvende omstandigheden meer psychosomatische klachten dan ouders met een hoger opleidingsniveau. De relatie van het opleidingsniveau met het psychosomatisch onwelbevinden van ouders is tegengesteld aan de relatie ervan met twee van de concrete problemen: ouders met een hoger niveau yan opleiding ervaren meer praktische druk en meer problemen met de partner dan ouders met een lager niveau van opleiding (zie 7.1.2).

Tenslotte zijn twee van de stresserende kenmerken van het verstandelijk gehandicapte kind gerelateerd aan het psychosomatisch onwelbevinden van ouders: zijn of haar gedragsproblemen en een gebrek aan sociale redzaamheid. Beide kenmerken zijn onder de assumpties van het basismodel niet rechtstreeks aan het welbevinden van ouders gerelateerd, maar op indirecte wijze, namelijk via hun relatie met de gezinsverstoring die ouders ervaren. Bovendien gaat een grote mate van gedragsproblematiek samen met een geringe zelfwaardering van ouders, hetgeen eveneens bijdraagt aan hun psychosomatisch onwelbevinden. Aangezien alle stresserende kenmerken van het verstandelijk gehandicapte kind in blok 1 van het basismodel zijn ondergebracht, wordt de gedragsproblematiek van het verstandelijk gehandicapte kind beschouwd als de variabele die uiteindelijk de belangrijkste determinant van de stress van ouders is.

\subsection{Het copingmodel (schema 6.2)}

In schema 6.2 is de wijze waarop ouders met problemen omgaan, coping, ingebracht als variabele die naast de variabelen uit het basismodel de verschillen in psychosomatisch welbevinden tussen ouders van een kind met een verstandelijke handicap zou kunnen verklaren. Vijf copingstijlen zijn onderzocht: een depressief reactiepatroon, sociale steun zoeken, een palliatieve reactie, vermijding en expressie van emoties (zie 6.1.1). Tabel 7.7 bevat de correlaties van deze copingstijlen met de concrete problemen van ouders (blok 5) en hun psychosomatisch onwelbevinden (blok 6). Bijlage C, tabel 2 bevat de correlaties met de variabelen uit de blokken $1 \mathrm{t} / \mathrm{m} 4$.

Om dle rol van coping in het stressproces bij ouders van een kind met een verstandelijke handicap te bestuderen, is eerst nagegaan of coping überhaupt iets toevoegt aan de verklaring van de variantie in het psychosomatisch onwelbevinden van de ouders naast de determinanten die uit de toetsing van het basismodel naar voren zijn gekomen. Hiertoe is een hiërarchische multiple regressie analyse uitgevoerd op deze afhankelijke variabele (zie ook 6.3.1).

Op basis van de resultaten van deze analyse (zie bijlage $C$, tabel 3) kan worden vastgesteld dat coping inderdaad een rol speelt. Na stap 1, waarin stapsgewijs de determinanten uit het basismodel zijn ingevoerd, i.c. gezinsverstoring, zelfwaardering en het opleidingsniveau van moeder, wordt $52 \%$ van de variantie in het psychosomatisch onwelbevinden verklaard (zie ook tabel 7.6). Na stap 2, waarin stapsgewijs de vijf copingstijlen zijn opgenomen, wordt $7 \%$ meer variantie verklaard en na stap 3 , waarin de 20 interactietermen tussen de vijf copingstijlen en de vier concrete problemen zijn ingevoerd, wordt nog eens 3\% meer variantie verklaard. Uiteindelijk 
verklaren de determinanten uit het basismodel, de copingstijlen en de interacties tussen coping en de concrete problemen van de ouders, samen $62 \%$ van de variantie in het psychosomatisch onwelbevinden van ouders.

\section{Tabel 7.7}

Pearson correlaties tussen de copingstijlen, blok 7 , en de concrete problemen en het psychosomatisch onwelbevinden van de ouders, blok 5 en 6 ( $n=181$ )

\begin{tabular}{|c|c|c|c|c|c|}
\hline \multirow[b]{2}{*}{ Blok 5 en 6} & \multicolumn{4}{|c|}{ Blok 7: Copingstijlen } & \multirow[b]{2}{*}{$\begin{array}{l}\text { Expressie } \\
\text { van emoties }\end{array}$} \\
\hline & $\begin{array}{l}\text { Depressief } \\
\text { reactie- } \\
\text { patroon }\end{array}$ & $\begin{array}{l}\text { Sociale } \\
\text { stem } \\
\text { zocken }\end{array}$ & $\begin{array}{l}\text { Pallia- } \\
\text { tieve } \\
\text { reactie }\end{array}$ & Vermijding & \\
\hline \multicolumn{6}{|l|}{ Blok 5: Concrete problemen } \\
\hline 1. Gezinsverstoring & $.44 * *$ & $22 *$ & .15 & .17 & $.29 \div$ \\
\hline 2. Praktische druk & $.24 *$ & .16 & .008 & .12 & .07 \\
\hline 3. Problemen m.b.t. de partner & $.26 * *$ & .07 & -.07 & .17 & .08 \\
\hline $\begin{array}{l}\text { 4. Zorgen over de ontwikkeling } \\
\text { van de andere kinderen }\end{array}$ & $.29^{* * *}$ & .16 & .18 & $.20^{*}$ & .07 \\
\hline \multicolumn{6}{|c|}{ Blok 6: Psychosomatisch onwelbevinden } \\
\hline $\begin{array}{l}\text { 5. Psychosomatisch } \\
\text { onwelbevinden }\end{array}$ & $.59 * *$ & .12 & .09 & $.24^{* *}$ & $.33^{* * *}$ \\
\hline
\end{tabular}

${ }^{*} \mathrm{p}<.01$, twee-zijdig. ${ }^{* *} p<.001$, twee-zijdig.

Vervolgens is nagegaan op welke wijze coping een rol speelt. Hiertoe zijn eerst de bêta's en hun significantieniveaus wit de hiërarchische regressie analyse bestudeerd (zie bijlage $C$, tabel 3), die de grootte van de eigen bijdrage van de betreffende predictor aan de verklaring van de variantie in het psychosomatisch onwelbevinden aangeven.

Hieruit blijkt in de eerste plaats dat ouders die veel concrete problemen ervaren niet meér profiteren van het gebruik ven een bepaalde copingstijl dan ouders met minder ernstige problemen. Aangezien geen van de bêta's van de interactietermen een statistisch significant niveau bereikt, kan geconcludeerd worden dat coping in samenhang met de concrete problemen geen modererende functie vervult ten aanzien van het psychosomatisch welbevinden van de ouders.

In de tweede plaats blijkt dat naarmate ouders de copingstijl depressief reactiepatroon frequenter hanteren, zij zich psychisch en somatisch slechter voelen $(B=.30$; $p<.001$ ). Het meer of minder frequent hanteren van én van de overige copingstijlen draagt onder de assumpties van het copingmodel niet bij aan het psychosomatisch wellbevinden van ouders.

Van de copingstijl depressief reactiepatroon is vervolgens nagegaan in hoeverre deze copingstijl wellicht een mediërende functie vervult (zie 2.4). Hiertoe zijn eerst de antecedenten van deze copingstijl bepaald. Aangezien coping in het copingmodel is 
geplaatst tussen de kenmerken van het gehandicapte kind, de ouders, de andere kinderen, de leeftijden van de gezinsleden en de concrete problemen (blok $1 \mathrm{t} / \mathrm{m} 5$ ) en het psychosomatisch onwelbevinden (blok 6), is met een stapsgewijze multiple regressie analyse nagegaan welke variabelen uit de blokken $1 \mathrm{t} / \mathrm{m} 5$ als antecedenten vain de copingstijl depressief reactiepatroon kunnen worden opgevat. De procedure is stopgezet toen geen van deze onafhankelijke variabelen meer een significante $(p<.01)$ eigen bijdrage leverde aan de verklaring van de variantie in deze copingstijl.

De resultaten van deze analyse (zie tabel 7.8) maken duidelijk dat ouders vaker een depressieve copingstijl hanteren naarmate zij meer gezinsverstoring ervaren en naarmate zif minder zelfwaardering hebben. Beide variabelen spelen, onder de assumpties van het basismodel, ook een belangrijke rol in de predictie van het psychosomatisch onwelbevinden van ouders. Dit kan erop duiden dat de copingstijl depressief reactiepatroon een mediërende rol speelt tussen de gezinsverstoring en de zelfwaardering van ouders enerzijds en hun psychosomatisch welbevinden anderzijds.

Tabel 7.8

Resultaten van de stapsgewijze multiple regressie analyse op de copingstijl depressief reactiepatroon met de variabelen uit de blokken $1 \mathrm{t} / \mathrm{m} 5$ als mogelijke predicto$\operatorname{ren}(n=181)$

\begin{tabular}{lllllllllr}
\hline Stap & Variabele & $\mathbb{R}$ & $\mathbb{R}^{2}$ & $\mathbb{R}^{2}$-change & $\mathbb{F}\left(R^{2}\right.$-change $)$ & d.f. & p< & B & \multicolumn{1}{c}{} \\
\hline 11. & Gezinsverstoring & .43 & .19 & .19 & 40.77 & 1,179 & .001 & .32 & .44 \\
2. & Zelfwaardering & .52 & .27 & .09 & 20.79 & 2,178 & .001 & -.31 & -.43
\end{tabular}

Van volledige mediatie is sprake wanneer beide determinanten uit het basismodel hun significante eigen bijdrage aan de verklaring van de variantie in het psychosomatisch onwelbevinden van ouders zouden verliezen wanneer de copingstijl depressief reactiepatroon bij de voorspelling van dit onwelbevinden wordt betrokken (Baron \& Kenny, 1986; zie ook 6.3.1).

In de hiërarchische regressie analyse met alle copingstijlen en álle interacties daarvan met de concrete problemen dragen beide determinanten uit het basismodel nog significant bij aan de predictie van het psychosomatisch onwelbevinden (zie bijlage $\mathrm{C}$, tabel 3 ).

Aangezien de bêta-gewichten echter afhangen van de overige in de set opgenomen predictoren, is een tweede hiërarchische multiple regressie analyse op het psychosomatisch onwelbevinden uitgevoerd, waarin na de determinanten uit het basismodel c.q. de antecedenten van een depressieve copingstijl (i.c. gezinsverstoring, zelfwaardering en opleidingsniveau van moeder), in de tweede stap alleen de copingstij1 depressief reactiepatroon is opgenomen. De resultaten van deze tweede hiërarchische regressie analyse staan vermeld in tabel 7.9 . 


\section{Tabel 7.9}

Resultaten van de hiërarchische multiple regressie analyse op het psychosomatisch onwelbevinden met de determinanten uit het basismodel en de copingstijl depressief reactiepatroon als predictoren $(n=181)$

\begin{tabular}{|c|c|c|c|c|c|c|c|c|c|}
\hline Stap & Variabele & $\mathbf{R}$ & $\mathbf{R}^{2}$ & $\mathrm{R}^{2}$-change & $\mathrm{F}\left(\mathbf{R}^{2}\right.$-change $)$ & d.f. & $\mathrm{p}<$ & $B$ & $r$ \\
\hline \multirow[b]{3}{*}{ c. } & & .58 & .34 & .34 & 92,00 & 1,179 & .001 & 37 & .61 \\
\hline & Zelf w aardering & .71 & .50 & .16 & 57.46 & 2,178 & .001 & -32 & -.61 \\
\hline & $\begin{array}{l}\text { Opleidingsniweau } \\
\text { moeder }\end{array}$ & .72 & .52 & .02 & 7.94 & 3,177 & .01 & -.15 & -16 \\
\hline 2. a. & $\begin{array}{l}\text { Depressief } \\
\text { reactiepatroon }\end{array}$ & .76 & .58 & .05 & 22.24 & 4,176 & .001 & .27 & .59 \\
\hline
\end{tabular}

De gegevens in tabel 7.9 laten zien dat alle determinanten uil het basismodel blifven bijdragen aan de voorspelling van het psychosomatisch onwelbevinden van de ouders wanneer de copingstijl depressief reactiepatroon in de analyse wordt opgenomen. Wel zijn de eigen bijdragen van de gezinsverstoring en de zelfwaardering van de ouders kleiner dan wanneer deze copingstijl niet bij de predictie van het onwelbevinden wordt betrokken (vergelijk de bêta's in tabel 7.9 met die in tabel 7.6).

Schema 7.2 vat de empirische bevindingen ten aanzien van het copingmodel samen.

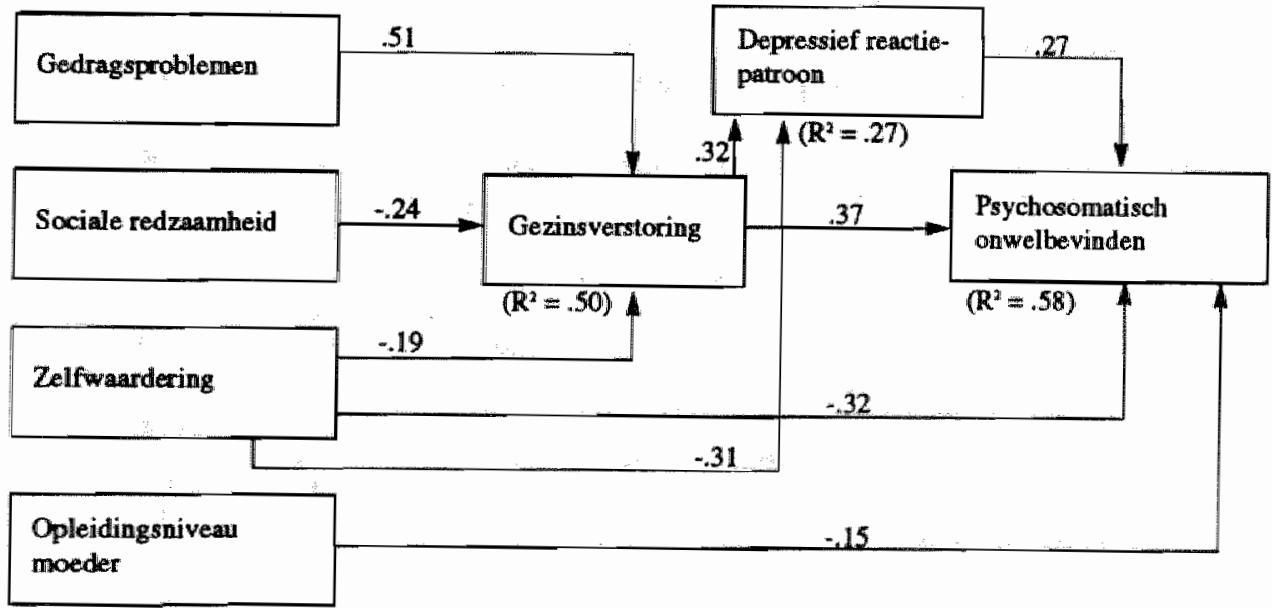

Schema 7.2. Copingmodel ten aanzien van stress bij ouders van een kind met een verstandelijke handicap: beperkt model

Uit schema 7.2 blijkt dat alleen de copingstijl depressief reactiepatroon van belang is in de predictie van de stress van ouders van een verstandelijk gehandicapt kind. Deze copingstijl vervult onder de assumpties van het copingmodel gedeeltelijk een 
mediërende functie: ouders die veel gezinsverstoring ervaren en ouders die een geringe zelfwaardering hebben, voelen zich in psychosomatisch opzicht slecht omdat zij als gevolg daarvan depressief op problemen reageren. Gedeeltelijk levert kennis over de frequentie van het gebruik van een depressieve copingstijl een extra verklaring voor de verschillen in de stress van ouders: wanneer deze variabele in de analyse wordt opgenomen, wordt $6 \%$ mér variantie in hun psychosomatisch onwelbevinden verklaard. Ouders die in het algemeen depressief op problemen reageren, voelen zich lichamelijk en geestelijk slechter dan ouders die deze copingstijl minder frequent hanteren, ongeacht de omstandigheden waarin zij zich bevinden.

\subsection{Het sociale-steunmodel (schema 6.3)}

In het model in schema 6.3 is sociale steun aan het basismodel toegevoegd als mogelijke verklaring voor de verschillen in stress tussen ouders van een verstandelijk gehandicapt kind. Zes indices voor sociale steun zijn bestudeerd: burgerlijke staat, totaal aantal steungevenden, lidmaatschap van een geloofsgemeenschap of levensbeschouwelijke groepering, partnersteun, steun uit het geloof of de levensbeschouwing en sociale isolatie. De eerste drie indices verwijzen naar structurele sociale steun, de laatste drie naar functionele sociale steun (zie 2.3 .3 en 3.4).

Tabel 7.10 bevat de correlaties tussen de zes indices voor sociale steun en de concrete problemen van ouders en hun psychosomatisch onwelbevinden (blok 5 en 6). De correlaties met de variabelen uit de blokken $1 \mathrm{t} / \mathrm{m} 4$ staan in bijlage $C$, tabel 4 .

Tabel 7.10

Pearson correlaties tussen de indices voor sociale steun, blok 8 , en de concrete problemen en het psychosomatisch onwelbevinden van de ouders, blok 5 en 6 $(n=181)$

Blok 8: Sociale steun

Blok 5 en 6

\begin{tabular}{llllll}
\hline Burger- & Partner- & Totaal & Lidimaat- & Steun & Sociale \\
lijke & steun & aantal & schap & uit & isolatio \\
staat & & steur- & geloofs- & geloof & \\
& & gevenden & gemeenschap &
\end{tabular}

Blok 5: Concrete problemen

$\begin{array}{lrrrrrr}\text { 1. Gezinsverstoring } & .03 & .01 & .01 & -.06 & -.13 & .39 * \\ \text { 2. Praktische druk } & -.03 & -.14 & .06 & -.02 & .09 & .36^{*} \\ \text { 3. Problemen m.b.t. de partner } & .00 & -.08 & -.03 & .01 & -.01 & .43^{*} \\ \text { 4. Zorgen over de ontwikke- } & -.05 & -.07 & .17 & .07 & -.05 & .24^{*}\end{array}$

Blok 6: Psychosomatisch onwelbevinden
5. Psychosomatisch
$-.08$
$.01 \quad-.04$
.17
$-.02$
$.46^{*}$
onwelbevinden

*p<.001, twee-zijdig. 
In het sociale-steunmodel is een onderscheid gemaakt tussen de wijze waarop structurele sociale steun een rol speelt bij de stress van ouders met een verstandelijk gehandicapt kind en de wijze waarop functionele sociale steun een rol in dit stressproces speelt (zie 3.4).

Verondersteld is dat structurele sociale steun een rol speelt bij de verklaring van de concrete problemen van ouders, naast de kenmerken van het verstandelijk gehandicapte kind, de kenmerken van de ouders, de kenmerken van de andere kinderen en de leeftijden van de gezinsleden. Om dit na te gaan is per concreet probleem een hiêrarchische multiple regressie analyse uitgevoerd. In de eerste stap zijn de determinanten van elk probleem uit het basismodel (zie tabel 7.5) stapsgewijs opgenomen, in de tweede stap zijn daaraan stapsgewijs de drie indices voor structurele sociale steun toegevoegd (zie ook 6.3.1).

De resultaten van deze vier regressie analyses maken duidelijk dat structurele sociale steun, gemeten aan de hand van de burgerlijke staat van de ouders, het totaal aantal steungevenden dat zij noemen en het al of niet lid zijn van een geloofsgemeenschap of levensbeschouwelijke groepering, niet van extra belang is voor de verklaring van de verschillen tussen ouders in de gezinsverstoring die zij ervaren, hun praktische druk, hun problemen met betrekking tot de partner en hun bezorgdheid over de ontwikkeling van de andere kinderen. De resultaten van de vier hiërarchische regressie analyses wijken niet af van de bevindingen van de analyses waarin alleen de kenmerken van het verstandelijk gehandicapte kind, de ouders en de andere kinderen en de leeftijden van de gezinsleden' (blok $1 \mathrm{t} / \mathrm{m} \mathrm{4}$ ) zijn opgenomen (zie tabel 7.5).

Voorts is verondersteld dat zowel structurele als functionele sociale steun een rol speelt bij de verklaring van de verschillen in het psychosomatisch welbevinden van de ouders. Dit gedeelte van het sociale-steunmodel is in essentie op dezelfde wijze onderzocht als het copingmodel (zie 7.2 en 6.3.1).

Eerst is nagegaan of sociale steun iets toevoegt aan de verklaring van de verschillen in het psychosomatisch onwelbevinden van ouders. Uit de resultaten van de hiertoe uitgevoerde hiërarchische multiple regressie analyse (bijlage $\mathrm{C}$, tabel 5) blijkt dat kennis over de steun die ouders uit hun sociale omgeving ontvangen, extra informatie oplevert met betrekking tot hun psychosomatisch onwelbevinden. Na de eerste stap verklaren de determinanten uit het basismodel samen $52 \%$ van de variantie in het welbevinden van ouders (zie ook tabel 7.6). Na de tweede stap, waarin de zes indices voor sociale steun stapsgewijs zijn ingevoerd, wordt $58 \%$ van de variantie verklaard. $\mathrm{Na}$ de derde stap, waarin de 24 interactietermen tussen deze indices en de vier concrete problemen stapsgewijs zijn toegevoegd, wordt $63 \%$ van de variantie verklaard. In totaal wordt $11 \%$ meer variantie in het psychosomatisch welbevinden van ouders verklaard dan wanneer alleen de determinanten uit het basismodel als predictoren worden opgenomen. 
Inspectie van de bêta's en de daarbij behorende significantieniveaus in bijlage $C$, tabel 5 leert vervolgens dat sociale steun de ouders niet beschermt tegen psychosomatisch onwelbevinden wanneer zij veel concrete problemen hebben. Aangezien geen van de interactietermen uit stap 3 van de hiërarchische regressie analyse significant bijdraagt aan de verklaring van de variantie in deze afhankelijke variabele, moet geconcludeerd worden dat sociale steun onder de aannames van het sociale steunmodel geen modererende functie heeft ten aanzien van het psychosomatisch onwelbevinden van de ouders.

Tevens blijkt dat ouders meer psychosomatische klachten hebben naarmate zij zich meer sociaal geïsoleerd voelen $(B=.18 ; p<.01)$. De andere indices voor de mate waarin ouders zich door mensen uit hun sociale omgeving ondersteund voelen, spelen geen rol in de voorspelling van hun psychosomatisch welbevinden. Dit geldt zowel voor de structurele als voor de overige functionele indices.

"Sociale isolatie" kan een mediërende functie vervullen. Uit bijlage $C$, tabel 5 blijkt namelijk dat de variabele "opleidingsniveau van moeder" zijn significante bijdrage aan de verklaring van het psychosomatisch onwelbevinden verliest wanneer alle indices voor sociale steun en álle interacties daarvan met de concrete problemen van ouders in de voorspelling worden opgenomen.

Om de mogelijk mediërende rol van sociale isolatie nader te onderzoeken, zijn eerst de antecedenten van sociale isolatie bepaald. Aangezien sociale isolatie als én van de indices voor functionele sociale steun volgens het sociale steun-model gedetermineerd kan worden door kenmerken van het verstandelijk gehandicapte kind, de ouders, de andere kinderen, de leeftijden van de gezinsleden en de concrete problemen van de ouders (blok $1 \mathrm{t} / \mathrm{m} \mathrm{5}$ ), zijn in de hiertoe gebruikte stapsgewijze multiple regressie analyse de variabelen in de blokken $1 \mathrm{t} / \mathrm{m} 5$ als mogelijke predictoren ingevoerd. De resultaten hiervan (zie tabel 7.11) laten zien dat ouders zich meer sociaal geïsoleerd voelen naarmate zij meer problemen met betrekking tot hun partner en meer gezinsverstoring ervaren én naarmate zij lager zijn opgeleid.

Tabel 7.11

Resultaten van de stapsgewijze multiple regressie analyse op sociale isolatie met de variabelen uit de blokken 1 t $m 5$ als mogelijke predictoren ( $n=181$ )

\begin{tabular}{llcccccccc}
\hline Stap & Variabele & $\mathrm{R}$ & $\mathrm{R}^{2}$ & $\mathrm{R}^{2}$-change & $\mathrm{F}\left(\mathrm{R}^{2}\right.$-change) & d.f. & $\mathrm{p}<$ & $\mathrm{B}$ & $\mathbb{}$ \\
\hline 1. & $\begin{array}{l}\text { Problemen } \\
\text { m.b.t. de }\end{array}$ & .43 & .18 & .18 & 40.13 & 1,179 & .001 & .35 & .43 \\
2. & $\begin{array}{l}\text { partner } \\
\text { Opleidings- }\end{array}$ & .48 & .23 & .05 & 11.48 & 2,178 & .001 & -.21 & -.14 \\
3. $\begin{array}{l}\text { nivenu vader } \\
\text { Gexinsver- } \\
\text { storing }\end{array}$ & .51 & .26 & .03 & 7.78 & 3.177 & .01 & .21 & .39 \\
\hline
\end{tabular}


Om te kunnen vaststellen of sociale isolatie inderdaad medieert tussen het opleidingsniveau en de concrete problemen van ouders enerzijds en hun psychosomatisch welbevinden anderzijds, is vervolgens een tweede hiërarchische multiple regressie analyse op het psychosomatisch onwelbevinden uitgevoerd. In de eerste stap zijn alle antecedenten van sociale isolatie ingevoerd (problemen met betrekking tot de partner, opleidingsniveau van vader en gezinsverstoring) alsmede de determinanten uit het basismodel (zie tabel 7.6). In de tweede stap is sociale isolatie toegevoegd.

\section{Tabel 7.12}

Resultaten van de hiërarchische multiple regressie analyse op het psychosomatisch onwelbevinden met de determinanten uit het basismodel en sociale isolatie als predictoren $(n=181)$

\begin{tabular}{|c|c|c|c|c|c|c|c|c|c|}
\hline Stap & Variabele & $\mathbf{R}$ & $\mathbb{R}^{2}$ & $\mathrm{R}^{2}$-change & $\mathrm{F}\left(\mathrm{R}^{2}\right.$-change) & d.f. & $p<$ & B & $r$ \\
\hline \multirow[t]{3}{*}{1.} & $\begin{array}{l}\text { Gezinsver- } \\
\text { storing }\end{array}$ & .58 & .34 & .34 & 92.00 & 1.179 & .001 & .38 & .61 \\
\hline & Zelfwaardering & .71 & .50 & .16 & 57.46 & 2,178 & .001 & -.39 & -.61 \\
\hline & $\begin{array}{l}\text { Opleidingsniveau } \\
\text { moeder }\end{array}$ & .72 & .52 & .02 & 7.94 & 3.177 & .01 & -.13 & -.16 \\
\hline 2. a. & Sociale isolatie & .75 & .56 & .04 & 14.84 & 4,176 & .001 & .21 & .46 \\
\hline
\end{tabular}

Uit de resultaten van deze analyse (zie tabel 7.12) blijkt, dat de variabelen "problemen met betrekking tot de partner" en "opleidingsniveau van vader", zoals verwacht, niet significant $(p<.01)$ bijdragen aan de verklaring van de variantie in het psychosomatisch onwelbevinden van ouders. De variabele "opleidingsniveau van moeder" blijft een weliswaar kleine, maar op p<.01-nivo significante eigen bijdrage aan de voorspelling van het psychosomatisch onwelbevinden van ouders leveren. Ook de variabele "gezinsverstoring" levert een minder grote eigen bijdrage aan de predictie van het onwelbevinden dan wanneer sociale isolatie niet in de analyse wordt betrokken (vergelijk de bêta's in tabel 7.12 met die in tabel 7.6).

Schema 7.3 vat de resultaten van de toetsingen van het sociale-steunmodel ten aanzien van stress bij ouders van een kind met een verstandelijke handicap samen.

Sociale isolatie is gedeeltelijk een medièrende factor tussen de gezinsverstoring en het opleidingsniveau wan ouders enerzijds en hun psychosomatisch onwelbevinden anderzijds: naarmate ouders meer gezinsverstoring ervaren en naarmate zij minder hoog zijn opgeleid, voelen zij zich onder de assumpties van het sociale-steunmodel in psychosomatisch opzicht slechter omdat zij meer sociaal geïsoleerd zijn.

Sociale isolatie levert gedeeltelijk ook onafhankelijk hiervan extra informatie op: opname van deze variabele voegt $4 \%$ toe aan de verklaring van de verschillen in stress tussen ouders van een verstandelijk gehandicapt kind. Ouders die zich ongeacht de omstandigheden waarin zij verkeren, in sociaal opzicht geïsoleerd voelen, hebben meer psychosomatische klachten dan ouders die zich niet of minder sociaal geïsoleerd voelen. 


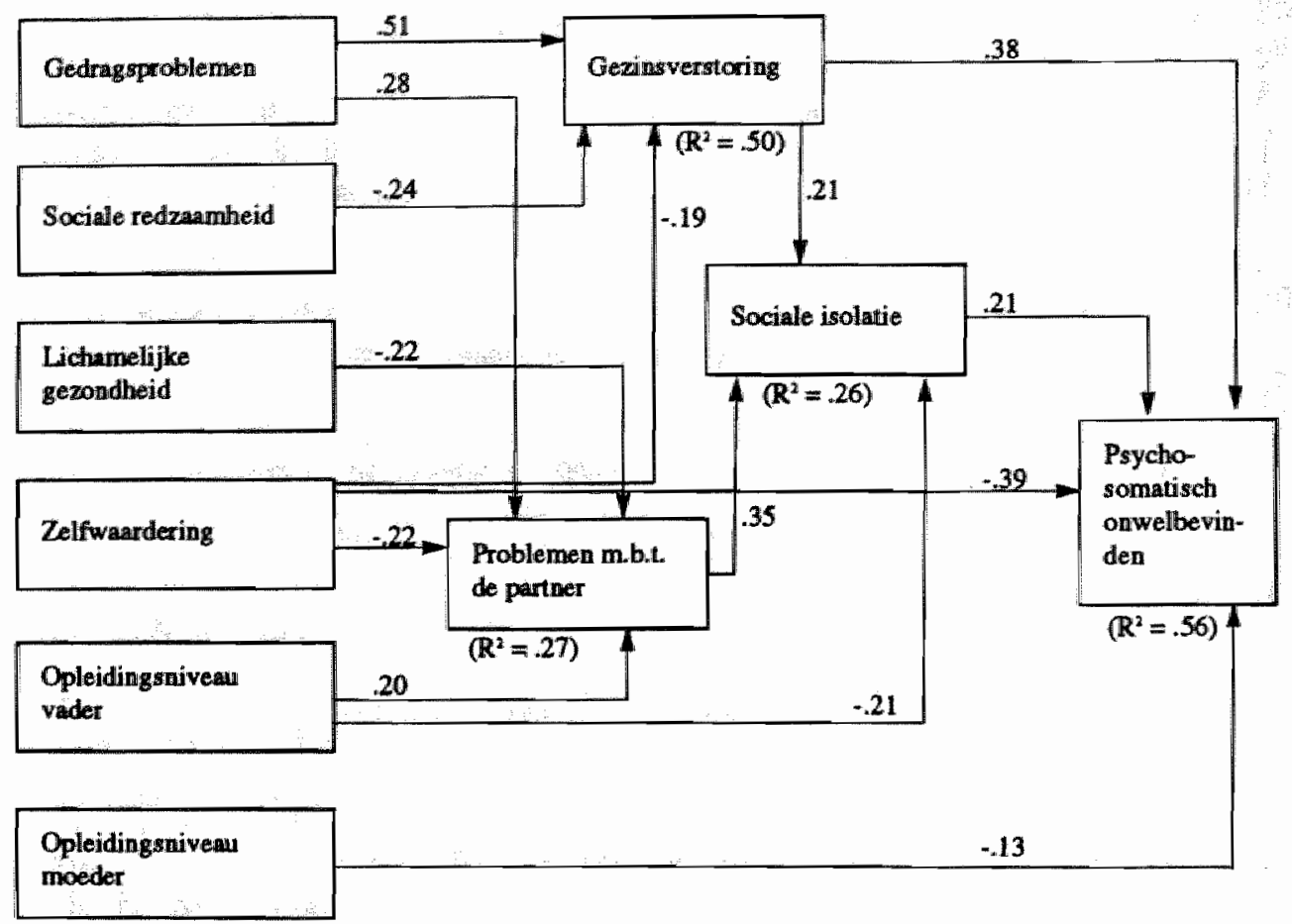

Schema 7.3. Sociale-steunmodel ten aanzien van stress bij ouders van een kind met een verstandelijke handicap: beperkt model

\subsection{Besluit: Toetsing van de stressmodellen}

\subsubsection{Samenvatting van de resultaten}

Uit de empirische toetsingen van de stressmodellen blijkt dat ouders die een kind met een verstandelijke handicap in het eigen gezin grootbrengen, meer concrete problemen ervaren naarmate dit kind meer stresserende kenmerken heeft, de ouders minder zelfwaardering hebben en de ouders een hogere opleiding hebben afgerond.

Onder de assumpties van het basismodel zijn van de vier bestudeerde stresserende kenmerken van het gehandicapte kind: (a) extraverte gedragsproblemen gerelateerd aan een toename in alle concrete problemen; (b) een geringe sociale redzaamheid gerelateerd aan een toename in de gezinsverstoring en in de zorgen over de ontwikkeling van de andere kinderen in het gezin; (c) geringe vaardigheden ten aanzien van sociaal gedrag en zelfredzaamheid gerelateerd aan een toename in de praktische druk van ouders; en (d) een zwakke lichamelijke gezondheid gerelateerd aan een toename in de problemen met betrekking tot de partner. Voorts hebben ouders meer 
concrete problemen naarmate hun zelfwaardering geringer is. Naarmate ouders een hogere opleiding hebben afgerond, ervaren zij meer praktische druk en meer problemen met betrekking tot de partner.

Onder de assumpties van het basismodel zijn voorts een grote mate van gezinsverstoring, een lage zelfwaardering en een laag opleidingsniveau van de ouders op directe wijze gerelateerd aan het psychosomatische onwelbevinden van de ouders. Op indirecte wijze dragen extraverte gedragsproblemen en een geringe sociale redzaamheid van het verstandelijk gehandicapte kind eveneens bij aan een grotere mate van psychosomatisch onwelbevinden bij de ouders. Aangezien met name deze gedragsproblematiek direct en indirect van groot belang blijkt te zijn voor de stress van ouders en aangezien dit stresserende kenmerk theoretisch in een eerste blok geplaatst is, kan deze gedragsproblematiek worden opgevat als de belangrijkste determinant van de stress van ouders.

Kennis over de copingstijlen die ouders hanteren, voegt iets toe aan de verklaring van de verschillen tussen ouders in de stress die zij ervaren. De vijf onderzochte copingstijlen, i.c een depressief reactiepatroon, sociale steun zoeken, een palliatieve reactie, vermijding en expressie van emoties, vormen in tegenstelling tot de verwachting echter geen buffer tegen psychosomatische klachten wanneer ouders veel concrete problemen hebben. Een depressief reactiepatroon is, onder de assumpties van het copingmodel; als enige copingstijl gerelateerd aan het psychosomatisch welbevinden van ouders: ouders die deze copingstijl frequenter hanteren, voelen zich slechter dan ouders die deze copingstijl minder frequent hanteren. Ouders hanteren deze copingstijl vooral wanneer zij veel gezinsverstoring ervaren en een negatief zelfbeeld hebben: als zodanig levert kennis over een depressieve copingstijl geen extra informatie op. Daarnaast draagt het frequent hanteren van een depressieve copingstijl ook ongeacht de ernst van de concrete problemen en ongeacht de persoonlijkheidskenmerken van ouders bij aan het psychosomatisch onwelbevinden van ouders: het feit dat sommige ouders in het algemeen depressief reageren op moeilijke situaties, vormt voor hen dan ook een probleem op zich.

Kennis over de steun die ouders uit hun sociale omgeving ontvangen, blijkt eveneens iets toe te voegen aan de verklaring van de verschillen tussen ouders in de stress die zij ervaren. In tegenstelling tot de verwachting levert de beschikbare, structurele sociale steun echter geen extra bijdrage aan de verklaring van de verschillen in de emst van de concrete problemen van ouders. Evenmin is aangetoond dat ouders met veel concrete problemen meer zouden profiteren van de beschikbare of waargenomen sociale steun dan ouders met weinig problemen. Van de zes bestudeerde indices voor sociale steun, i.c. burgerlijke staat, partnersteun, totaal aantal steungevenden, lidmaatschap van een geloofsgemeenschap of levensbeschouwelijke groepering, steun uit het geloof of de levensbeschouwing en sociale isolatie, zijn bovendien alleen gevoelens van sociale isolatie gerelateerd aan het psychosomatisch onwelbevinden van ouders. Onder de assumpties van het sociale-steunmodel vervult sociale isolatie gedeeltelijk een mediërende rol: naarmate ouders lager zijn opgeleid en naarmate zijj meer concrete problemen ervaren, voelen zij zich meer sociaal geïsoleerd hetgeen 
bijdraagt aan thun psychosomatisch onwelbevinden. Gedeeltelijk is sociale isolatie op te vatten als een apart probleem: ongeacht de stressvolle omstandigheden van ouders en ongeacht hun opleidingsniveau, leggen gevoelens van sociale isolatie een extra druk op hun psychosomatisch welbevinden.

\subsubsection{Implicaties voor de hypotheses ten aanzien van de hulpverlening}

De empirische bevindingen van de toetsingen van de stressmodellen hebben implicaties voor de hypotheses die zijn opgesteld ten aanzien van de drie te bestuderen hulpvormen, i.c. Praktisch Pedagogische Gezinsbegeleiding, Praktische Thuishulp en Weekendopvang (zie hoofdstuk 5). Deze hypotheses betreffen zowel de kenmerken van de gezinnen die deze achtereenvolgende hulpvormen aanvragen als de effecten van de hulp op de stress van de ouders en de determinanten daarvan. Zij hebben telkens betrekking op een gedeelte van de variabelen uit de stressmodellen. Daar waar de toetsingen van deze modellen verbanden hebben aangetoond met andere (blokken van) variabelen, kunnen deze hypotheses worden aangevuld.

De hypotheses ten aanzien van Praktisch Pedagogische Gezinsbegeleiding hebben betrekking op variabelen uit de blokken 1 (stresserende kenmerken van het verstandelijk gehandicapte kind), 2 (kenmerken van de ouders), 5 (concrete problemen) en 6 (psychosomatisch onwelbevinden). Ten aanzien van de kenmerken van de gezinnen die deze hulp aanvragen, kunnen op basis van de toetsingen van de stressmodellen drie hypotheses worden toegevoegd, die evenals in 5.1 met het cijfer 1 beginnen:

In gezinnen die Praktisch Pedagogische Gezinsbegeleiding aanvragen:

Hypothese 1-5: behoren de ouders tot een lagere sociale klasse c.q. hebben de ouders een lager opleidingsniveau;

Hypothese 1-6: hanteren de ouders vaker de copingstijl "depressief reactiepatroon"; en

Hypothese 1-7: voelen de ouders zich meer sociaal geïsoleerd, dan in gezinnen die geen Praktisch Pedagagische Gezinsbegeleiding aanvragen.

Ten aanzien van de effecten van PPG kunnen twee hypotheses worden toegevoegd. Deze beginnen met een 2:

In gezinnen die Praktisch Pedagogische Gezinsbegeleiding hebben gehad:

Hypothese 2-5: zijn de ouders minder vaak de copingstijl "depressief reactiepatroon" gaan gebruiken; en

Hypothese 2-6: heeft zich bij de ouders een grotere afname in de gevoelens van sociale isolatie voorgedaan, dan in gezinnen die geen Praktisch Pedagogische Gezinsbegeleiding hebben gehad.

Op basis van de beschrijving van Praktische Thuishulp is in 5.2 eén hypothese opgestell betreffendle de praktische druk in deze gezinnen (blok 5). Met betrekking tot de kenmerken van de gezinnen die deze hulp aanvragen, geven de toetsingen van de stressmodellen aanleiding tot het opstellen van drie aanvullende hypotheses, die met het cijfer 3 beginnen: 
In gezinnen die Praktische Thuishulp aanvragen:

Hypothese 3-2: heeft het verstandelijk gehandicapte kind meer stresserende kenmerken, met name meer gedragsproblemen en minder vaardigheden ten aanzien van sociaal gedrag en zelfredzaamheid;

Hypothese 3-3: behoren de ouders tot een hogere sociale klasse c.q. hebben de ouders, met name de vaders, een hoger opleidingsniveau; en

Hypothese 3-4: hebben de ouders minder zelfwaardering, dan in gezinnen die geen Praktische Thuishulp aanvragen.

Ten aanzien van de effecten van de hulp zijn twee hypotheses toegevoegd. Deze beginnen evenals in 5.2 met het cijfer 4 :

In gezinnen die Praktische Thuishulp hebben:

Hypothese 4-2: heeft zich een grotere afname in de stresserende kenmerken van het verstandelijk gehandicapte kind voorgedaan, met name wat de gedragsproblematiek en de vaardigheden ten aanzien van sociaal gedrag en zelfredzaamheid betreft; en

Hypothese 4-3: hebben de ouders meer zelfwaardering gekregen, dan in gezinnen die geen Praktische Thuishulp hebben.

De beschrijving van de projecten Weekendopvang leidde tot twee hypotheses die betrekking hebben op de concrete problemen van ouders (blok 5) en hun psychosomatisch onwelbevinden (blok 6; zie 5.3). De resultaten van de toetsingen van de stressmodellen voegen aan de hypotheses betreffende de kenmerken van de gezinnen die deze hulp aanvragen, vijf hypotheses toe, die met een 5 beginnen:

In gezinnen die Weekendopvang aanvragen:

Hypothese 5-3: heeft het verstandelijk gehandicapte kind meer stresserende kenmerken:

Hypothese 5-4: behoren de ouders tot een lagere sociale klasse c.q. hebben de ouders een lager opleidingsniveau;

Hypothese 5-5: hebben de ouders minder zelfwaardering;

Hypothese 5-6: hanteren de ouders vaker de copingstijl "depressief reactiepatroon", en

Hypothese 5-7: voelen de ouders zich meer sociaal geisoleerd, dan in gezinnen die geen Weekendopvang aanvragen.

Ten aanzien van de effecten van de hulp zijn vier aanvullende hypotheses opgesteld, die met het cijfer 6 beginnen:

In gezinnen die Weekendopvang hebben:

Hypothese 6-3: heeft zich een grotere afname in de stresserende kenmerken wan het verstandelijk gehandicapte kind voorgedaan;

Hypothese 6-4: hebben de ouders meer zelfwaardering gekregen;

Hypothese 6-5: zijn de ouders minder vaak de copingstijl "depressief reactiepatroon" gaan gebruiken; in

Hypothese 6-6: heeft zich bij de ouders een grotere afname in de gevoelens van sociale isolatie voorgedaan, dan in gezimnen die geen Weekendopvang hebben. 


\section{Resultaten II: Hulpvragers en hulpvragen}

Wat zijn de kenmerken van de gezinnen die zich aanmelden bij Praktisch Pedagogische Gezinsbegeleiding, Praktische Thuishulp en Weekendopvang en wat zijn hun hulpvragen? Hoofdstuk 8 geeft de resultaten weer van de analyses die zijn uitgevoerd om deze eerste twee evaluatieve subvraagstellingen te beantwoorden (zie 1.3). $\mathrm{Na}$ een korte beschrijving van de gezinnen in de controlegroep vindt de presentatie van de resultaten per hulpvorm plaats in $8.2,8.3 \mathrm{en} 8.4$.

\subsection{De controlegroep}

Bij het onderhavige onderzoek zijn 60 ouders betrokken die ten tijde van de voormeting geen gebruik maken van noch een aanvraag voor hulp hebben ingediend bij Praktisch Pedagogische Gezinsbegeleiding, Praktische Thuishulp en Weekendopvang: de controlegroep (zie 6.2). De meeste van hen zijn op de hoogte van het bestaan van deze hulpvormen: 43 ouders hebben wel eens van Praktisch Pedagogische Gezinsbegeleiding gehoord, 46 ouders wel eens van Praktische Thuishulp en 36 ouders wel eens van de projecten Weekendopvang.

De ouders in de controlegroep hebben echter weinig behoefte aan de hulp die deze hulpvormen bieden. Van de 60 ouders heeft 1 ouderpaar "veel" en 5 ouders "enigszins" behoefte aan hulp bij de opvoeding van en de omgang met het gehandicapte kind. Voorts hebben 3 ouders "veel" en 7 ouders "enigszins" behoefte aan hulp bij problemen van praktische aard. Tenslotte hebben 3 ouders "veel" en 13 ouders "enigszins" behoefte aan Weekendopvang voor het gehandicapte kind. De ouders in de controlegroep kunnen beschouwd worden als "gemiddelde" ouders van een kind met een verstandelijke handicap die, voor zover zij al behoefte hebben aan professionele hulp op de genoemde gebieden, daar althans ten tijde van de voormeting geen gebruik van maken of willen gaan maken. 
Tabel 8.1

Gemiddelden en standaarddeviaties van de variabelen in de blokken 1.2 en 5 t/m 8 van de controle - en de hulpverleningsgroepen: voormeting

\begin{tabular}{|c|c|c|c|c|}
\hline \multirow[b]{2}{*}{ Variabelen } & \multicolumn{4}{|c|}{ Groepen } \\
\hline & $\begin{array}{l}\text { Conirole } \\
(n=60)\end{array}$ & $\begin{array}{l}\text { PPG } \\
(n=58)\end{array}$ & $\begin{array}{l}\text { PT } \\
(n=25)\end{array}$ & $\begin{array}{l}\text { WO } \\
(n=64)\end{array}$ \\
\hline \multicolumn{5}{|c|}{ Blok 1: Stresserende kenmerken verstande lijk gehandicapt kind } \\
\hline 1. Gedragsproblemen & $\begin{array}{l}1.53 \\
(.43)\end{array}$ & $\begin{array}{l}2.08 * * * \\
(.54)\end{array}$ & $\begin{array}{l}1.56 \\
(.57)\end{array}$ & $\begin{array}{l}1.60 \\
(.41)\end{array}$ \\
\hline 2. Sociale redzaamheid & $\begin{array}{l}2.77 \\
(.34)\end{array}$ & $\begin{array}{l}2.41^{* * * *} \\
(.45)\end{array}$ & $\begin{array}{l}2.64 \\
(.44)\end{array}$ & $\begin{array}{l}2.72 \\
(.33)\end{array}$ \\
\hline $\begin{array}{l}\text { 3. Socialle vaardigheden en } \\
\text { zelfredzaamheid }\end{array}$ & $\begin{array}{l}2.31 \\
(.53)\end{array}$ & $\begin{array}{l}2.09 * \\
(.48)\end{array}$ & $\begin{array}{l}2.04^{*} \\
(.50)\end{array}$ & $\begin{array}{l}2.24 \\
(.52)\end{array}$ \\
\hline 4. Lichamelijke gezondheid & $\begin{array}{l}2.36 \\
(.66)\end{array}$ & $\begin{array}{l}2.31 \\
(.71)\end{array}$ & $\begin{array}{l}2.16 \\
(.69)\end{array}$ & $\begin{array}{l}2.30 \\
(.70)\end{array}$ \\
\hline \multicolumn{5}{|l|}{ Blok 2: Kenmerken van de ouders } \\
\hline 5. Sociale klasse & $\begin{array}{l}3.51 \\
(1.47)\end{array}$ & $\begin{array}{l}2.62 * * \\
(1.32)\end{array}$ & $\begin{array}{l}4.24 * \\
(1.36)\end{array}$ & $\begin{array}{l}3.59 \\
(1.62)\end{array}$ \\
\hline 6. Opleidingsniveau moeder & $\begin{array}{l}2.80 \\
(1.26)\end{array}$ & $\begin{array}{l}2.69 \\
(1.44)\end{array}$ & $\begin{array}{l}3.72 * * \\
(1.57)\end{array}$ & $\begin{array}{l}2.98 \\
(1.55)\end{array}$ \\
\hline 7. Opleidingsniveau vader & $\begin{array}{l}3.39 \\
(1.68)\end{array}$ & $\begin{array}{l}2.94 \\
(1.67)\end{array}$ & $\begin{array}{l}4.55^{* *} \\
(1.77)\end{array}$ & $\begin{array}{l}3.59 \\
(2.06)\end{array}$ \\
\hline 8. Zelfwaardering & $\begin{array}{l}2.59 \\
(.43)\end{array}$ & $\begin{array}{l}2.27 \\
(.53)\end{array}$ & $\begin{array}{l}2.50 \\
(.47)\end{array}$ & $\begin{array}{l}2.62 \\
(.41)\end{array}$ \\
\hline \multicolumn{5}{|l|}{ Blok 5: Concrete problemen } \\
\hline 9. Gezinsverstoring & $\begin{array}{l}1.44 \\
(.49)\end{array}$ & $\begin{array}{l}1.90^{* * * *} \\
(.55)\end{array}$ & $\begin{array}{l}1.81 * * \\
(.63)\end{array}$ & $\begin{array}{l}1.68^{*} \\
(.50)\end{array}$ \\
\hline 10. Praktische druk & $\begin{array}{l}1.54 \\
(.54)\end{array}$ & $\begin{array}{l}1.89 * * \\
(.65)\end{array}$ & $\begin{array}{l}2.03^{* * * *} \\
(.62)\end{array}$ & $\begin{array}{l}1.77 * * \\
(.59)\end{array}$ \\
\hline 11. Problemen m.b.t. de partner & $\begin{array}{l}1.37 \\
(.41)\end{array}$ & $\begin{array}{l}1.59 * \\
(.52)\end{array}$ & $\begin{array}{l}1.70^{*} \\
(.47)\end{array}$ & $\begin{array}{l}1.48 \\
(.38)\end{array}$ \\
\hline $\begin{array}{l}\text { 12. Zorgen over de ontwikkeling } \\
\text { van de andere kinderen }\end{array}$ & $\begin{array}{l}1.19 \\
(.31)\end{array}$ & $\begin{array}{l}1.48 * * \\
(.51)\end{array}$ & $\begin{array}{l}1.44 * \\
(.56)\end{array}$ & $\begin{array}{l}1.38 * \\
(.39)\end{array}$ \\
\hline \multicolumn{5}{|c|}{ Blok 6: Psychosomatisch onwelbevinden } \\
\hline $\begin{array}{l}\text { 13. Psychosomatisch } \\
\text { onwellbevinden }\end{array}$ & $\begin{array}{l}1.63 \\
(.45)\end{array}$ & $\begin{array}{l}1.91^{* * *} \\
(.48)\end{array}$ & $\begin{array}{l}1.66 \\
(.43)\end{array}$ & $\begin{array}{r}1.62 \\
(.38)\end{array}$ \\
\hline \multicolumn{5}{|l|}{ Blok 7 : Coping } \\
\hline 14. Depressief reactiepatroon & $\begin{array}{l}1.98 \\
(.39)\end{array}$ & $\begin{array}{l}2.21 * * \\
(.51)\end{array}$ & $\begin{array}{l}2.25 * \\
(.55)\end{array}$ & $\begin{array}{l}2.01 \\
(.42)\end{array}$ \\
\hline \multicolumn{5}{|l|}{ Blok 8: Sociale steun } \\
\hline 15. Sociale isolatie & $\begin{array}{l}1.48 \\
(.56)\end{array}$ & $\begin{array}{l}1.79 * * \\
(.61)\end{array}$ & $\begin{array}{l}1.59 \\
(.55)\end{array}$ & $\begin{array}{l}1.49 \\
(.49)\end{array}$ \\
\hline
\end{tabular}

Verschil met de controlegroep:

${ }^{*} \mathrm{p}<.05$, een-zijdig. ${ }^{*}$ p $<<.01$, een-zijdig. ${ }^{* * *}$ p $<.001$, een-zijdig. 
De eerste kolom van tabel 8.1 bevat van de controlegroep de gemiddelden en de standaarddeviaties op de variabelen waarover voor eén of meer hulpvormen hypotheses zijn opgesteld. De frequenties, gemiddelden en standaarddeviaties op de overige variabelen staan vermeld in bijlage $D$, tabel 1 en 2 .

\subsection{Praktisch Pedagogische Gezinsbegeleiding}

In totaal hebben 58 ouders de vragenlijst ingevuld alvorens van Praktisch Pedagogische Gezinsbegeleiding (PPG) gebruik te maken. De tweede kolom van tabel 8.1 bevat de gemiddelden en standaarddeviaties van de scores van deze ouders op de variabelen waarover hypotheses zijn opgesteld. De scores op de overige variabelen staan vermeld in bijlage $\mathrm{D}$, tabel 1 en 2 . Verschillen met de controlegroep staan eveneens in de tweede kolom van de genoemde tabellen aangegeven.

De 58 gezinnen uit de PPG-groep worden in 8.2.1 kort beschreven. Paragraaf 8.2.2 geeft de resultaten weer van de analyses ter toetsing van de hypotheses betreffende de kenmerken van deze gezinnen. In 8.2.3 worden de hulpvragen van de PPG-ouders besproken.

\subsubsection{Beschrijving van de PPG-gezinnen}

Van de 58 ouders in de PPG-groep hebben 19 ouders een verstandelijk gehandicapte dochter en 39 een gehandicapte zoon (zie bijlage $\mathrm{D}$, tabel 2): er zijn meer jongens en minder meisjes in de PPG-groep dan in de controlegroep (chi ${ }^{2}(1)=11.78 ; p<.001$ ). Van de 58 ouders zijn 10 ouders, allen moeders, alleenstaand: dit zijn er relatief meer dan in de controlegroep $\left(\operatorname{chi}^{2}(1)=17.22 ; p<.001\right)$. De leeftijden van de gehandicapte kinderen lopen uiteen van 16 maanden tot 30 jaar, met een gerniddelde van ruim 7 jaar. Hun moeders zijn tussen 24 en 56 jaar oud, hun vaders tussen 26 en 58 jaar. De verstandelijk gehandicapte kinderen en hun ouders zijn gemiddeld genomen jonger dan de kinderen en hun ouders in de controlegroep (multivariate $F(3,99)=4.46 ; p<.01)$.

Onder de verstandelijk gehandicapte kinderen in de PPG-groep zijn meer enig kinderen en minder jongste kinderen dan in de controlegroep (chi² 3$)=1.97 ; p<.001$ ). Voor zover er andere kinderen in het gezin zijn, zijn deze in de PPG-groep jonger dan in de controlegroep $(t(88)=-2.63 ; p<.01$, twee-zijdig), terwijl de relatie tussen het gehandicapte kind en deze kinderen in de PPG-gezinnen slechter is dan in de gezinnen in de controlegroep ( $t(88)=-5.56 ; p<.001$, twee-zijdig).

\subsubsection{Toetsing van de hypotheses}

Op basis van de beschrijving van de hulpverlening (zie 5.1) en de resultaten van de toetsingen van de stressmodellen (zie 7.4.2) zijn in totaal zeven hypotheses opgesteld ten aanzien van de kenmerken van de PPG-gezinnen:

In gezinnen die Praktisch Pedagogische Gezinsbegeleiding aanvragen: 
Hypothese 1-1: heeft het verstandelijk gehandicapte kind meer stresserende kenmerken, met name meer gedragsproblemen en een geringere sociale redzaamheid:

Hypothese 1-2: hebben de ouders minder zelfwaardering:

Hypothese 1-3: ervaren de ouders meer concrete problemen;

Hypothese 1-4: woelen de ouders zich in psychosomatisch opzicht slechter;

Hypothese 1-5: behoren de ouders tot een lagere sociale klasse c.q. hebben de ouders een lager opleidingsniveau;

Hypothese 1-6: hanteren de ouders vaker de copingstijl "depressief reactiepatroon"; en

Hypothese 1-7: voelen de ouders zich meer sociaal geisoleerd, dan in gezinnen die geen Praktisch Pedagogische Gezinsbegeleiding aanvragen.

Multivariate variantie analyses (MANOVA's) zijn gebruikt voor de toetsing van de hypotheses 1-1 en 1-5 en voor de concrete problemen "gezinsverstoring", "praktische druk" en "problemen met betrekking tot de partner" uit hypothese 1-3. Student"s t-toetsen zijn gebruikt voor de toetsing van de hypotheses 1-2,1-4, 1-6 en 1-7 en, gezien het grote aantal gezinnen in de PPG-groep waarin het verstandelijk gehandicapte kind enig kind is (zie 8.2.1), voor het vierde probleemgebied uit hypothese 1-3, "zorgen over de ontwikkeling van de andere kinderen" (zie ook 6.3.2).

Tabel 8.2

Analyse-resultaten van de hypothese-toetsingen ten aanzien van de kenmerken van de $P P G-$ groep

Hypotheses

Resultaten

1. Stresserende kenmerken verstandelijk gehandicapt kind

multivariate $\mathrm{F}(4,97)=12.61 ; \mathrm{p}<, 001$

univariaat: gedragsproblemen: $p<, 001$

sociale redzaamheid: $p<, 001$

saciale vaardigheden en

zelfredzaamheid: $p<.05$

12. Zelfwaardering

13. Concrete problemen

$t(114)=-3.58$; $p<001$, een-zijdig

a. Gezinsverstoring, praktische druk, problemen m.b.t. de partner

multivariate $\mathrm{F}(3,97)=6.45 ; \mathrm{p}<.001$

univariaat: gezinswerstoring: $p<.001$

praktische druk: $\mathrm{p}<.01$

problemen m.b.t. de partner: $p<.05$

b. Zorgen over de ontwikkeling van de andere kinderen

14. Psychosomatisch onwelbevinden

15. Socialle klasse/opleidingsniveau

16. Depressief reactiepatroon

17. Sociale isolatie $t(82)=2.85 ;$ p<.01, een-zijdig

(114)=3.31; p<001, een-zijdig

multivariate $F(3,99)=3,33 ; p<.05$

univariaat: sociale klasse: $p<, 01$

opleidingsniveau moeder: n.s.

opleidingsniveau vader: n.s.

(1112) $=2.69 ;$ p $<.01$, een-zijdig

$\mathfrak{t}(113)=2.85$; $p<.01$, een-zijdig 
Uit het overzicht van de analyse-resultaten in tabel 8.2 blijkt dat de hypotheses ten aanzien van de kenmerken van de gezinnen die Praktisch Pedagogische Gezinsbegeleiding aanvragen, geen van alle zijn verworpen. Vergeleken met gezinnen die geen Praktisch Pedagogische Gezinsbegeleiding aanvragen, zijn de gezinnen in de PPGgroep zwaar belasi: de verstandelijk gehandicapte kinderen hebben meer stresserende kenmerken, de sociale klasse van de gezinnen is lager, de zelfwaardering van de ouders is geringer, de concrete problemen zijn emstiger, de ouders hanteren vaker de copingstijl "depressief reactiepatroon", voelen zich meer sociaal geissoleerd en hebben meer psychosomatische klachten.

De grotere mate van stress in de PPG-groep ten opzichte van de controlegroep is niet te verklaren uit de verschillen tussen beide groepen in de burgerlijke staat van de ouders of het geslacht van het gehandicapte kind (zie 8.2.1). Dit blijkt uit de (M)ANCOVA's op alle variabelen uit de hypotheses waarin achtereenvolgens gecontroleerd is voor de verbanden met deze demografische kenmerken (zie 6.3.2). Aan de jongere leeftijd van de gehandicapte kinderen in de PPG-groep is wel toe te schrijven dat zij minder sociaal vaardig en zelfredzaam zijn, maar niet dat zij meer gedragsproblemen en een geringere sociale redzaamheid hebben (hypothese 1-1). Aan de jongere leeftijd van de PPG-groep zijn de overige verschillen met de controlegroep evenmin toe te schrijven.

De grotere belasting van de ouders in de PPG-groep is daarentegen wél te verklaren uit de algemene determinanten van de stress van ouders. De toetsingen van de stressmodellen hebben duidelijk gemaakt wat de determinanten zijn van de concrete problemen van ouders (zie tabel 7.5), een depressieve copingstijl (zie tabel 7.8), de mate van sociale isolatie van ouders (zie tabel 7.11) en hun psychosomatisch onwelbevinden (zie tabel 7.6). De zelfwaardering van ouders heeft geen determinanten in de strikte zin van het woord omdat deze variabele in de stressmodellen als exogene variabele is opgevat. Wel bestaat er in het algemeen een belangrijke correlatie met de gedragsproblematiek van het gehandicapte kind (zie bijlage C, tabell 1).

Uit (M)ANCOVA's (zie 6.3.2) blijkt dat de verschillen tussen de PPG-groep en de controlegroep in de zelfwaardering van de ouders (hypothese 1-2), de ernst van de concrete problemen (hypothese 1-3), het gebruik van een depressieve copingstijl (hypothese 1-6), de gevoelens van sociale isolatie (hypothese 1-7) en het psychosomatisch onwelbevinden (hypothese 1-4) tot stand komen via de belangrijkste correlaat respectievelijk de determinanten van deze variabelen. Aangezien de hypotheses $1-1$ en 1-5 exogene variabelen zonder belangrijke correlaten betreffen, zijn deze niet nader geanalyseerd. Dit betekent een extra ondersteuning voor de stressmodellen: het psychosomatisch onwelbevinden is ook bij ouders die PPG aanvragen, te verklaren vanuit de gedragsproblemen van het gehandicapte kind, een geringe zelfwaardering van de ouders, een lage sociale klasse, een grote mate van concrete problemen, veelvuldig gebruik van een depressieve copingstijl en gevoelens van sociale isolatie. Bovendien is de grote belasting van de ouders in de PPG-groep 
onder de assumpties van de stressmodellen uiteindelijk te verklaren uit de gedragsproblematiek wan de verstandelijk gehandicapte kinderen in deze groep.

\subsubsection{Hulpvragen en subgroepen}

De 58 ouders in de PPG-groep noemen gemiddeld twee opvoedingsproblemen die zij met behulp van Prakktisch Pedagogische Gezinsbegeleiding hopen te leren hanteren of op te lossen. De hulpvragen hebben betrekking op (a) de gedragsproblemen van het verstandelijk gehandicapte kind, (b) de stimulering van de ontwikkeling van het gehandicapte kind, (c) de omgang tussen het gehandicapte kind en de overige gezinsledlen, (d) de sociale vaardigheden van het kind, van belang bij de omgang van het kind met mensen buiten het gezin, en (e) andere gebieden.

Alle ouders met een zelfde hulpvraag zijn in eén subgroep ondergebracht zodat vijf subgroepen zijn ontstaan. Gezinnen in één subgroep zijn telkens vergeleken met alle overige PPG-gezinnen wat de stress van de ouders betreft en de determinanten

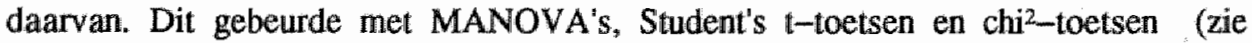
6.3.2). Aangezien de ouders gemiddeld twee hulpwragen stellen en dus gemiddeld in twee subgroepen geplaatst zijn, sluiten deze subgroepen elkaar niet uit. De analyses zijn uitgevoerd vanwege de mogelijke bruikbaarheid van de uitkomsten voor de praktijk van de hulpverlening. De uitkomsten moeten met de nodige voorzichtigheild geïnterpreteerd worden.

\section{Subgroep gedragsproblemen ( $n=36$ )}

Bijna twee derde van de ouders noemt eén of meer gedragsproblemen van het verstandelijk gehandicapte kind als reden voor hun aanmelding bij Praktisch Pedagogische Gezinsbegeleiding. Zij noemen voomamelijk extraverte gedragsproblemen, zoals agressief en destructief gedrag, ongehoorzaamheid, driftbuien, druk en opgewonden gedrag en problemen rond de maaltijd. Bij de vergelijkingen tussen de subgroep "gedragsproblemen" en de overige PPG-gezinnen blijkt deze subgroep zich te onderscheiden in:

(a) de stresserende kenmenken van de gehandicapte kinderen (multivariate $F(4,43)=4.03 ; p<.01)$ : de kinderen in deze subgroep hebben meer gedragsproblemen (univariaat: $\mathrm{p}<.05$ ) en zijn sociaal vaardiger en zelfredzamer (univariaat: p<.05);

(b) de concrete problemen: de ouders in de subgroep ervaren meer gezinsverstoring en praktische druk (multivariate $F(3,43)=3.14 ; p<.05$; univariaat: $p<.01$ respectievelijk $\mathrm{p}<<_{i} 05$ );

(c) coping (multivariate $F(5,48)=2.67 ; p<.05$ ): de ouders in de subgroep "gedragsproblemen" gebruiken met name de copingstijl "vermijding" vaker (univariaat: $\mathrm{p}<.01$ ); en

(d) sociale steun: de ouders in de subgroep "gedragsproblemen" noemen minder mensen die hen emotioneel steunen $(t(46)=-2.24 ; p<.05$, twee-zijdig) dan de overige PPG-ouders. 


\section{Subgroep ontwikkelingsstimulering ( $n=25$ )}

lets minder dan de helft van de ouders heeft. Praktisch Pedagogische Gezinsbegeleiding aangevraagd om geholpen te worden bij de stimulering van de ontwikkeling van het verstandelijk gehandicapte kind. Van hen hebben 9 ouders hulp gevraagd bij de ontwikkeling van het spelen, 4 ouders bij de ontwikkeling van de zelfredzaamheid, 3 ouders bij de taalontwikkeling en 2 ouders bij de bevordering van de zelfstandigheid van het kind. Voorts zoeken 5 ouders PPG-hulp bij de stimulering van de verstandelijke ontwikkeling van het kind en de overige 2 ouders bij de verstandelijke en motorische ontwikkeling van het gehandicapte kind. De vergelijkingen tussen deze subgroep en de overige PPG-gezinnen maken duidelijk dat in de subgroep "ontwikkelingsstimulering":

(a) de verstandelijk gehandicapte kinderen gemiddeld jonger zijn $(M=5.0$ jaar respectievelijk $M=9.1$ jaar; $t(56)=-2.90 ; p<.01$, twee-zijdig);

(b) de verstandelijk gehandicapte kinderen lichamelijk minder gezond zijn (multivariate $F(4,43)=2.59 ; p<.05$; univariaat: $p<.01$ ). Dit verschil is niet toe te schrijven aan hun jongere leeftijd, zoals blijkt uit een MANCOVA op de stresserende kenmerken met de leeftijd van de kinderen als covariaat; en

(c) de ouders zich minder sociaal geïsoleerd voelen $(\mathrm{t}(56)=-2.41 ; \mathrm{p}<.05$, tweezijdig) en meer mensen noemen die hen emotioneel steunen $(t(46)=2.13 ; p<.05$, twee-zijdig). Deze verschillen in sociale steun worden evenmin verklaard door het leeftijdsverschil tussen beide PPG-subgroepen.

\section{Subgroep omgangsproblemen binnen het gezin ( $n=17)$}

De problemen waarbij de ouders in de subgroep "omgangsproblemen binnen het gezin" geholpen willen worden, betreffen gedeeltelijk de relatie tussen de ouders en het gehandicapte kind, zoals een te sterke binding tussen moeder en kind, de afwezigheid van (oog-) contact bij autistiforme kinderen en voortdurende conflicten tussen ouders en kind, en gedeeltelijk de relaties tussen het gehandicapte kind en zijn of haar broer(s) en/of zus(sen), zoals vaak ruzie hebben en niet samen kunnen spelen. Negen ouders menen dat de gezinsverhoudingen mede door de gedragsproblematiek van het gehandicapte kind verstoord zijn geraakt en hebben Praktisch Pedagogische Gezinsbegeleiding ook aangevraagd om deze gedragsproblemen te doen afnemen. De ouders in de subgroep "omgangsproblemen binnen het gezin" voelen zich meer sociaal geïsoleerd dan de overige PPG-ouders $(t(56)=3.04 ; p<.01$, twee-zijdig). Andere verschillen zijn niet aangetoond.

\section{Subgroep sociale vaardigheden $(n=11)$}

De ouders die problemen met de sociale vaardigheden van het gehandicapte kind als reden noemen voor hun aanvraag van Praktisch Pedagogische Gezinsbegeleiding, gaat het voornamelijk om hulp bij het aanleren van de vaardigheden die het kind in staat stellen contacten buiten het gezin, met name met leeftijdgenoten, te maken en te onderhouden. Er zijn geen verschillen aantoonbaar tussen de ouders in deze subgroep en de overige 47 PPG-ouders. 
Hulpvragen op andere terreinen ( $n=13$ )

Door 13 ouders zijn andere redenen genoemd bij hun aanmelding bij Praktisch Pedagogische Gezinsbegeleiding, zoals hulp bij de acceptatie van de verstandelijke handicap van het kind, hulp bij de sexuele opvoeding van het kind, hulp bij het verkrijgen van een zekere regelmaat in de hwishouding en hulp die erop gericht is het gehandicapte kind of de ouders meer zelfvertrouwen te geven. De hulpvragen zijn te divers om deze ouders als én subgroep te beschouwen.

\subsubsection{Samenvatting: Hulpwragers en hulpwragen bij PPG}

Ouders die zich aanmelden bij Praktisch Pedagogische Gezinsbegeleiding zoeken hulp bij opvoedkundige moeilijkheden. De beschrijving van hetgeen landelijk over PPG bekend is, leidde tot de veronderstelling dat ouders die deze hulp aanvragen, zich in aanzienlijke mate belast voelen. Dit beeld is in het onderhavige onderzoek bevestigd. Ouders die Praktisch Pedagogische Gezinsbegeleiding aanvragen, ervaren veel concrete problemen en voelen zich geestelijk en lichamelijk slecht. Dit is, zoals verwacht, te verklaren uit de determinanten die in het algemeen gerelateerd zijn aan de belasting van ouders: de aanzienlijke gedragsproblemen en geringe sociale redzaamheid van het veelal nog jonge gehandicapte kind, de lage sociale klasse van de ouders, de geringe zelfwaardering van de ouders, het veelvuldig gebruik van een depressieve copingstijl en het gevoel er alleen voor te staan.

In het algemeen zijn de stresserende kenmerken van het gehandicapte kind en met name zijn of haar gedragsproblemen de belangrijkste determinanten van de stress van ouders. Het leven met een verstandelijk gehandicapt kind blijkt inderdaad het zwaarst te zijn voor ouders wier hulpvraag het problematische gedrag van het gehandicapte kind betreft. Andere hulpvragen bij PPG hebben betrekking op de stimulering van de ontwikkeling van jonge, veelal lichamelijk zwalkke verstandelijk gehandicapte kinderen, de relaties binnen het gezin en de ontwikkeling van de sociale vaardigheden van het gehandicapte kind ten behoeve van contacten met mensen buiten het gezin. Het landelijke beeld dat ouders die PPG aanvragen, vaak meervoudige opvoedingsvragen hebben, is in deze studie eveneens bevestigd.

\subsection{Praktische Thuishulp}

Bij het onderzoek zijn 25 ouders betrokken die de vragenlijst hebben ingevuld na hun aanmelding bij één van de zes projecten Praktische Thuishulp (PT). De derde kolom van tabel 8.1 bevat de gemiddelden en standaarddeviaties van de scores van deze 25 ouders op de variabelen waarover hypotheses zijn opgesteld. De scores op de overige variabelen staan vermeld in bijlage $D$, tabel 1 en 2 . Verschillen met de controlegroep staan ook in de derde kolom van de genoemde tabellen aangegeven.

De PT-groep wordt in 8.3.1 kort beschreven. Paragraaf 8.3.2 geeft de resultaten weer van de toetsingen van de hypotheses ten aanzien van de kenmerken van de PTgezinnen. In 8.3.3 komen de hulpvragen van de ouders aan de orde en in 8.3.4 de frequentie waarmee zij een beroep willen doen op de Praktische Thuishulp. 


\subsubsection{Beschrijving van de PT-gezinnen}

Van de 25 PT-ouders hebben 9 ouders een dochter met een verstandelijke handicap en 16 een gehandicapte zoon. De leeftijden van deze kinderen lopen uiteen van 17 maanden tot ruim 30 jaar, met een gemiddelde van 9 jaar. De ouders zijn gemiddeld ruim 37 jaar oud en de andere kinderen in het gezin gemiddeld ruim 8 jaar. De relaties tussen het gehandicapte kind en zijn of haar broer(s) en/of zus(sen) zijn in de PT-groep slechter dan in de controlegroep $(t(70)=-1.94 ; p<.05$, twee-zijdig, zie bijlage $\mathrm{D}$, tabel 1). Het aantal alleenstaande ouders is in de PT-groep even gering als in de controlegroep.

\subsubsection{Toetsing van de hypotheses}

Naar aanleiding van de beschrijving van Praktische Thuishulp (zie 5.2) en de toetsingen van de stressmodellen (zie 7.4.2) zijn vier hypotheses opgesteld met betrekking tot de kenmerken van de gezinnen die deze hulp aanvragen:

In gezinnen die Praktische Thuishulp aanvragen:

Hypothese 3-1: ervaren de ouders meer praktische druk;

Hypothese 3-2: heeft het verstandelijk gehandicapte kind meer stresserende kenmerken, met name meer gedragsproblemen en minder vaardigheden ten aanzien van sociaal gedrag en zelfredzaamheid;

Hypothese 3-3: behoren de ouders tot een hogere sociale klasse c.q. hebben de ouders, met name de vaders, een hoger opleidingsniveau; en

Hypothese 3-4: hebben de ouders minder zelfwaardering, dan in gezinnen die geen Praktische Thuishulp aanvragen.

De hypotheses 3-2 en 3-3 zijn met MANOVA's getoetst, de hypotheses 3-1 en 3-4 met Student's t-toetsen (zie 6.3.2).

Tabel 8.3

Analyse-resultaten van de hypothese-toetsingen ten aanzien van de kenmerken van de PT-groep

Hypotheses

3-1. Praktische druk

3-2. Stresserende kenmerken verstandelijk gehandicapt kind

multivariate $F(2,73)=2.83 ; p<10$

uniwariaat: gedragsproblemen: n.s.

sociale vaardigheden en zelfredzarmbeid: $p<.05$

3-3. Sociale klasse/opleidingsniveau

multivariate $F(3,73)=3.72 ; p<01$

univariaal: sociale klasse: $p<.05$

opleidingsniveau moeder: $p<01$

opleidingsniveau vader: $\mathrm{p}<01$ 
Uit het overzicht van de analyse-resultaten in tabel 8.3 blijkt dat twee van de vier hypotheses niet verworpen kunnen worden: de ouders die Praktische Thuishulp aanvragen, ervaren meer praktische druk en hebben een hoger niveau van opleiding dan de ouders in de controlegroep. De verstandelijk gehandicapte kinderen in de PT-groep hebben iets minder vaardigheden ten aanzien van sociaal gedrag en zelfredzaamheid. Hun gedragsproblematiek is niet zoals verwacht groter dan in de controlegroep. De ouders in de PT-groep hebben evenmin een geringere zelfwaardering dan de ouders in de controlegroep.

De grotere praktische druk in de PT-groep (hypothese 3-1) kan niet worden toegeschreven aan de algemene determinanten van dit concrete probleem, i.c. de gedragsproblemen en de sociale en zelfredzaamheidsvaardigheden van het verstandelijk gehandicapte kind, de zelfwaardering van de ouders en het opleidingsniveau van vader (zie tabel 7.5). De PT-groep blijft meer praktische druk ervaren dan de controlegroep, ook wanneer de verbanden met deze determinanten in een ANCOVA worden uitgepartialiseerd (zie 6.3.2).

\subsubsection{Hulpwragen en subgroepen}

De 25 PT-ouders hebben gemiddeld twee antwoorden gegeven op de open vraag om welke redenen zij Praktische Thuishulp hebben aangevraagd. Een deel van de antwoorden heeft betrekking op het soort hulp dat men heeft aangevraagd, namelijk (a) oppas, (b) bezigheidsbegeleiding, (c) hulp bij de verzorging van het gehandicapte kind, en (d) hulp bij vervoersproblemen. Daamaast hebben 11 ouders aangegeven dat zij met de hulp (e) een verlichting van hun taken hopen te bewerkstelligen.

Alle ouders met een zelfde reden voor hun aanmelding bij Praktische Thuishulp zijn in één subgroep samengebracht zodat vijf subgroepen zijn ontstaan. Getracht is na te gaan in hoeverre deze. PT-subgroepen van de overige PT-gezinnen afwijken in de stress van de ouders en de determinanten daarvan (zie 6.3.2). De geringe omvang van de subgroepen maakt het noodzakelijk de uitkomsten van deze vergelijkingen met meer voorbehoud te presenteren dan bij de PPG-subgroepen reeds het geval was (zie 8.2.3).

\section{Subgroep oppas $(n=15)$}

De gezinnen die via Praktische Thuishulp een deskundige, vertrouwde en vaste oppas voor hun gehandicapte kind hopen te vinden, lijken van de overige 10 gezinnen af te wijken met betrekking tot de plaats van het gehandicapte kind in de kinderrij en zijn of haar leeftijd. In de totale PT-groep zijn 7 kinderen het jongste kind in het gezin (zie bijlage D, tabel 2). Van deze 7 ouders zoeken 6 ouders oppas. De gemiddelde leeftijd van de gehandicapte kinderen in de subgroep "oppas" is dan ook lager dan de gemiddelde leeftijd van de overige kinderen ( $M=6.4$ jaar respectievelijk $M=12.9$ jaar; $t(23)=-2.34 ; p<.05$, twee-zijdig). 


\section{Subgroep bezigheidsbegeleiding $(n=7)$}

De gexinnen die Praktische Thuishulp hebben aangevraagd opdat de vrijwilliger leuke dingen met het gehandicapte kind gaat doen, zoals spelen, wandelen, zwemmen, aandacht geven als moeder druk is met koken, lijken alleen van de overige 18 PT-gezinnen te verschillen wat het geslacht van het gehandicapte kind betreft: 6 van de 7 kinderen voor wie bezigheidsbegeleiding is aangevraagd, zijn jongens.

\section{Subgroep hulp bij de verzorging ( $n=4$ )}

Praktische Thuishulp is door 4 ouders aangevraagd voor hulp bij de verzorging van het verstandelijk gehandicapte kind. Van deze kinderen heeft 1 kind een zwakke lichamelijke gezondheid en zijn de overige kinderen meervoudig gehandicapt.

\section{Subgroep vervoersproblemen ( $n=3)$}

Bij 3 ouders vormen problemen in het vervoer met een auto, bijwoorbeeld naar een arts of een hobbyclub, een reden om zich bij Praktische Thuishulp aan te melden.

\section{Subgroep taakverlichting ( $n=11)$}

De ouders die Praktische Thuishulp hebben aangevraagd ter verlichting van hun taken, hebben verschillende soorten hulp aangevraagd: oppas ( 8 ouders), bezigheidsbegeleiding ( 1 ouderpaar), hulp bij de verzorging ( 2 ouders) en hulp bij vervoersproblemen ( 1 ouderpaar). Er lijken geen verschillen te bestaan tussen de ouders in de subgroep "taakverlichting" en de overige PT-ouders wat de emst van hun concrete problemen en hun psychosomatisch onwelbevinden betreft. Wel is er eén verschil met betrekking tot de plaats van het gehandicapte kind in de kinderrij $\left(\operatorname{chi}^{2}(3)=33.3\right.$; p<.001). Slechts 1 van de 11 gehandicapte kinderen in de subgroep "taakverlichting" is het jongste in het gezin tegenover 6 van de 14 overige kinderen. Daarentegen zijn 7 wan de 11 gehandicapte kinderen in de subgroep "taakverlichting" het oudste kind in het gezin, tegenover 3 van de 14 kinderen in de overige PT-gezinnen.

\subsubsection{Gewenste frequentie}

Van de 22 ouders die de vraag hoe vaak zij gebruik willen maken van Praktische Thuishulp, hebben beantwoord, geven 10 ouders aan dat tenminste eens per week te willen doen, 6 ouders eens per twee weken, 5 ouders eens per maand en 1 ouderpaar eens per twee tot drie maanden. Er is geen relatie tussen de gewenste frequentie en de hulpvragen van de ouders. Correlaties met de variabelen uit de blokken 1 t/m 8 laten zien dat ouders vaker gebruik willen maken van Praktische Thuishulp naarmate het gehandicapte kind minder sociaal vaardig en zelfredzaam is $(r=-.59$; $\mathrm{p}<.01$, een-zijdig). Andere significante relaties zijn niet aangetroffen.

\subsubsection{Samenvatting: Hulpvragers en hulpvragen bij PT}

Praktische Thuishulp biedt hulp bij problemen en vragen van praktische aard. Gezien de geringe omvang van de PT-groep in het onderhavige onderzoek en gezien het feit dat landelijk weinig bekend is over gezinnen die Praktische Thuishulp aanvragen, moeten conclusies over de kenmerken van deze gezinnen voorzichtig worden getrok- 
ken. De ouders die zich bij de centrales aanmelden, lijken een hoog opleidingsniveau te hebben. Hun gehandicapte kind lijkt gemiddeld genomen weinig sociaal vaardig en weinig zelfredzaam te zijn. De ouders ervaren, zoals verwacht, vrij veel concrete problemen, met name veel praktische druk. Hun zelfwaardering lijkt even hoog te zijn als die van ouders die geen Praktische Thuishulp aanvragen.

Deskundige oppas is de meest aangevraagde hulpsoort bij de zes centrales in het onderzoek. Oppas wordt vooral aangevraagd door ouders van een jong verstandelijk gehandicapt kind. De vraag naar bezigheidsbegeleiding lijkt vooral te leven bij ouders van een verstandelijk gehandicapte zoon. De vraag naar hulp bij de verzorging van het gehandicapte kind wordt vrij weinig gesteld en dan voomamelijk door ouders van een meervoudig gehandicapt of lichamelijk zwak kind. Hulp bij vervoersproblemen is eveneens een weinig gestelde vraag. Vooral ouders wier gehandicapte kind het oudste kind is, vragen Praktische Thuishulp aan ter verlichting van hun taken. De frequentie waarmee ouders Praktische Thuishulp hopen te ontvangen, is voor elk van de aangevraagde soorten hulp even hoog, namelijk gemiddeld eens per twee weken.

\subsection{Weekendopvang}

In totaal hebben 64 ouders de vragenlijst ingevuld bij hun aanmelding voor cén van de drie projecten Weekendopvang (WO). De gemiddelden en standaarddeviaties van deze ouders op de variabelen waarover hypotheses zijn opgesteld, staan vermeld in de vierde kolom van tabel 8.1. De scores op de overige variabelen staan in bijlage D, tabel 1 en 2. Verschillen met de controlegroep staan eveneens in de vierde kolom van de genoemde tabellen aangegeven.

Paragraaf 8.4.1 geeft een korte beschrijving van de gezinnen in de WO-groep. In 8.4.2. komen de resultaten aan de orde van de toetsingen van de hypotheses ten aanzien van de kenmerken van deze gezinnen. In 8.4.3 staan de hulpvragen van de ouders in de WO-groep centraal en in 8.4 .4 de frequentie waarmee zij gebruik hopen te maken van de Weekendopvang.

\subsubsection{Beschrijving van de WO-gezinnen}

Onder de 64 verstandelijk gehandicapte kinderen wier ouders Weekendopvang hebben aangevraagd, zijn 28 meisjes en 36 jongens. Hun leeftijden lopen uiteen van 3 tot 19 jaar, met een gemiddelde van ruim 12 jaar. De gemiddelde leeftijd van hun moeders is 40 jaar, van hun vaders ruim 42 jaar en van de andere kinderen in het gezin nuim 12 jaar. Onder de oudlers in de WO-groep bevinden zich drie alleenstaande moeders.

Weekendopvang wordt vooral aangevraagd door gezinnen waarin het gehandicapte kind het oudste is en door gezinnen waarin het gehandicapte kind zowel (een) jongere als (een) oudere broer(s) en/of zus(sen) heeft ( $\operatorname{chi}^{2}(3)=11.77 ; \mathrm{p}<.01$, zie bijlage $\mathrm{D}$, tabel 2). In de WO-gezinnen met meer kinderen is de relatie tussen deze 
kinderen slechter dan in die gezinnen in de controlegroep $(t(107)=-2.97 ; p<.01$, twee-zijdig, zie bijlage $\mathrm{D}$, tabel 1 ).

\subsubsection{Toetsing van de hypotheses}

Op basis van de beschrijving van de projecten Weekendopvang (zie 5.3) en de resultaten van de toetsingen van de stressmodellen (zie 7.4.2) zijn in totaal zeven hypotheses opgestell ten aanzien van de kenmerken van de gezinnen in de WOgroep:

In gezinnen die Weekendopvang aanvragen:

Hypothese 5-1: ervaren de ouders meer concrete problemen;

Hypothese 5-2: voelen de ouders zich in psychosomatisch opzicht slechter;

Hypothese 5-3: heeft het verstandelijk gehandicapte kind meer stresserende kenmerken;

Hypothese 5-4: behoren de ouders tot een lagere sociale klasse c.q. hebben de ouders een lager opleidingsniveau;

Hypothese 5-5: hebben de ouders minder zelfwaardering:

Hypothese 5-6: hanteren de ouders vaker de copingstijl "depressief reactiepatroon"; en

Hypothese 5-7: voelen de ouders zich meer sociaal gelsoleerd, dan in gezinnen die geen Weekendopvang aanvragen.

Tabel 8.4 geeft een overzicht van de analyse-resultaten.

Tabel 8.4

Analyse-resultaten van de hypothese-toetsingen ten aanzien wan de kenmerken van de WO-groep

Hypotheses Resulliten

$5-1$. Concrete problemen

multivariate $F(4,90)=2.30 ; p<.10$

univariaat: gezinswerstoring: $\mathrm{p}<.05$

praktische druk: p<.01

problemen met betrekking tot de partner: n.s. zorgen over de ontwikkeling van de andere kinderen: p<.05

5-2. Psychosomatisch onwelbevinden n.s.

5-3. Stresserende kermerken verstandelijk gehandicapt kind n..s.

5-4. Sociale klasse/opleidingsniveau n.s.

5-5. Zelfwardering nus.

5-6. Depressief reactiepatroon n.s.

5-7. Sociale isolatie m.s.

Uit de gegevens in tabell 8.4 blijkt dat de hypotheses 5-2 t/m 5-7 verworpen moeten worden. Alleen hypothese $5-1$ is niet verworpen: ouders die Weekendopvang aanvragen, ervaren meer gezinsverstoring en praktische druk en maken zich meer bezorgd over de ontwikkeling van hun andere kinderen dan ouders die geen Week- 
endopvang aanvragen. Verschillen tussen ouders in de emst van hun concrete problemen worden, onder de assumpties van de stressmodellen, in het algemeen gemedieerd door de stresserende kenmerken van het gehandicapte kind, de zelfwaardering van ouders en het opleidingsniveau van vader (zie tabel 7.5). De grotere ernst van drie van de vier concrete problemen in de WO-groep ten opzichte van de controlegroep is echter niet aan deze determinanten toe te schrijven: de ouders in de WO-groep blijven meer concrete problemen ervaren dan de ouders in de controlegroep ook wanneer de verbanden met deze determinanten in een MANCOVA worden uitgepartialiseerd (zie 6.3.2).

\subsubsection{Hulpwragen en subgroepen}

De ouders hebben gemiddeld twee redenen genoemd voor hun aanmelding bij de projecten Weekendopvang. Deze redenen weerspiegelen de verwachtingen die zij van de opvang hebben. Zij betreffen gedeeltelijk de ouders zelf en de andere kinderen in het gezin, namelijk (a) rust en ontspanning voor de ouders, (b) het ondernemen van activiteiten die met het gehandicapte kind erbij niet of nauwelijks mogelijk zijn, (c) tijd, rust en aandacht voor de andere kinderen in het gezin, en (d) ontlasting van de extra zorg voor het gehandicapte kind. Andere redenen die bij de aanmelding genoemd worden, zijn (e) ontspanning voor het verstandelijk gehandicapte kind, (f) gewenning aan een toekomstige uithuisplaatsing van het gehandicapte kind, en (g) een vertrouwde opvang voor het gehandicapte kind.

Alle ouders die een zelfde reden voor hun aanmelding bij de projecten Weekendopvang noemen, zijn in eén subgroep ondergebracht, zodat in totaal zeven subgroepen zijn ontstaan. Aangezien deze elkaar deels overlappen, moeten de resultaten van de analyses die zijn uitgevoerd om na te gaan in welke opzichten de achtereenvolgende subgroepen van de overige WO-gezinnen afwijken wat de stress van de ouders en de determinanten daarvan betreft (zie 6.3.2), voorzichtig worden geïnterpreteerd.

\section{Subgroep rust voor de ouders ( $n=26$ )}

Ongeveer $40 \%$ van de ouders heeft Weekendopvang aangevraagd om zelf een weekend rust te hebben, te ontspannen, "op adem te komen en bij te tanken". De vergelijkingen tussen de gezinnen in deze subgroep en de 38 overige WO-gezinnen laten zien dat in de subgroep "rust voor de ouders":

(a) de verstandelijk gehandicapte kinderen meer gedragsproblemen hebben (multivariate $F(4,58)=2.19 ; p<.10$; univariaat: $p<.01)$;

(b) de zelfwaardering van de ouders lager is $(\mathrm{t}(62)=-1.79 ; \mathrm{p}<.10$, twee-zijdig);

(c) de ouders meer gezinsverstoring ervaren (multivariate $F(3,55)=2.61 ; p<.10$; univariaat: $\mathrm{p}<.01$ ); en

(d) het psychosomatisch welbevinden van de ouders slechter is $(\mathrm{t}(62)=2.12 ; \mathrm{p}<.05$, twee-zijdig).

\section{Subgroep activiteiten ( $n=16$ )}

Een kwart van de ouders heeft als reden voor hun aanvraag genoemd dat zij activiteiten willèn ondememen die naar hun mening met het gehandicapte kind erbij 
nauwelijks mogelijk zijn, zoals winkelen, wandelen, fietsen, sporten, een avond uit, naar het theater of de film, op bezoek bij familie of vrienden, en een weekend weg. Er zijn enkele verschillen tussen de ouders die om deze reden Weekendopvang aanvragen en de 48 overige ouders:

(a) de gezinnen in de subgroep "activiteiten" zijn jonger dan de resterende WOgezinnen (multivariate $F(4,48)=2.95 ; p<.05$ ), en

(b) de gehandicapte kinderen in de subgroep "activiteiten" hebben meer stresserende kenmerken (multivariate $F(4,58)=5.26 ; p<.001$ ): zij zijn minder sociaal redzaam (univariaat: $p<.01$ ) en hebben minder vaardigheden ten aanzien van sociaal gedrag en zelfredzaamheid (univariaat: p<.001). Dit verschil is niet toe te schrijven aan hun jongere leeftijd. Wanneer leeftijd als covariaat wordt opgenomen in een MANCOVA op de stresserende kenmerken, blijken de gehandicapte kinderen in de subgroep "activiteiten" niet alleen minder sociaal redzaam, sociaal vaardig en zelfredzaam te zijn, maar eveneens meer gedragsproblemen (univariaat: $\mathrm{p}<.05$ ) te hebben.

\section{Subgroep tijd voor de andere kinderen ( $n=15)$}

De ouders die Weekendopvang aanvragen om meer tijd en aandacht te kunnen besteden aan de andere kinderen in het gezin, menen dat het verstandelijk gehandicapte kind zoveel tijd en aandacht vraagt dat de andere kinderen wel eens te kort komen. Bovendien menen zij dat de andere kinderen zo nu en dan ongestoord hun eigen gang moeten kunnen gaan en ruimte moeten hebben voor hun eigen ontwikkeling, zonder in hun spel of sociale bezigheden rekening te hoeven houden met hun gehandicapte broer of zus. De vergelijkingen met de resterende WO-gezinnen laten zien dat in de subgroep "tijd voor de andere kinderen":

(a) de gehandicapte kinderen jonger zijn ( $M=9.4$ jaar respectievelijk $M=13.1$ jaar; multivariate $F(4,48)=2.39 ; p<.10$; univariaat: $p<.01$ );

(b) de gehandicapte kinderen meer stresserende kenmerken hebben (multivariate $F(4,58)=3.02 ; p<.05)$ : zij zijn minder sociaal vaardig en zelfredzaam (univariaat: $p<.01$ ), hebben meer gedragsproblemen (univariaat: $p<.05$ ) en zijn minder sociaal redzaam (univariaat: $\mathrm{p}<, 05$ ). Deze verschillen worden door hun jongere leeftijd verklaard; en

(c) de concrete problemen van de ouders ernstiger zijn (multivariate $F(4,46)=6.58$; $\mathrm{p}<.001)$ : zij maken zich meer zorgen over de ontwikkeling van deze kinderen (univariaat: $p<.001$ ), ervaren meer gezinsverstoring (univariaat: $p<.001$ ) en meer praktische druk (univariaat: $\mathrm{p}<.05$ ). Ook wanneer rekening gehouden wordt met de verschillen in leeftijd en stresserende kenmerken van het gehandicapte kind, ervaren de ouders in de subgroep "tijd voor de andere kinderen" meer concrete problemen dan de overige WO-ouders, zoals uit een MANCOVA blijkt.

\section{Subgroep ontlasting van de extra zorg ( $n=10$ )}

De ouders die de opvang hebben aangevraagd om eens een weekend ontlast te zijn van de extra zorg voor het verstandelijk gehandicapte kind willen, zoals éen van hen het verwoordde, "eens een keer een gewoon gezin zijn", zonder voortdurend op het gehandicapte kind te hoeven opletten, zonder het kind voortdurend te hoeven bezighouden en zonder te hoeven denken aan zijn of haar medicatie of dieet. Er zijn 
geen verschillen gevonden tussen de gezinnen in deze subgroep en de overige 54 gezinnen.

\section{Subgroep ontspanning voor hel werstandelijk gehandicapte kind $(n=28)$}

In totaal hebben 28 ouders Weekendopvang aangevraagd om hon verstandelijk gehandicapte kind in staat te stellen ook buiten schooltijd met leeftijd- en niveaugenoten te spelen. Het kind dreigt geissoleerd te raken en begint zich thuis te vervelen omdat er niet altijd mensen zijn om mee te spelen. Bovendien zou het voor het kind goed zijn te leren sociale contacten te leggen en het gezin los te laten. De verschillen tussen deze subgroep en de overige WO-gezinnen betreffen:

(a) de leeftijden van de gezinsleden (multivariate $F(4,48)=2.66 ; p<.05$ ): het verstandelijk gehandicapte kind en de andere kinderen in het gezin zijn in deze subgroep ouder dan in de overige WO-gezinnen (verstandelijk gehandicapte kinderen: $M=14.1$ jaar respectievelijk $M=10.7$ jaar; univariaat: $p<.01$; de andere kinderen: $M=14.2$ jaar respectievelijk $M=11.1$ jaar; univariaat: $p<10$ );

(b) de plaats van het gehandicapte kind in de kinderrij $\left(\operatorname{chi}^{2}(3)=14.92 ; p<.01\right)$ : veel gehandicapte kinderen in deze subgroep zijn enig kind of het middelste kind en weinig kinderen zijn het jongste kind; en

(c) de stresserende kenmerken van de verstandelijk gehandicapten (multivariate $F(4,58)=8.46 ; p<.001)$ : de kinderen in de subgroep "ontspanning voor het verstandelijk gehandicapte kind" zijn sociaal vaardiger en meer zelfredzaam (univariaat: $\mathrm{p}<.001$ ), zijn sociaal redzamer (univariaat: $\mathrm{p}<.01$ ), lichamelijk gezonder (univariaat: $\mathrm{p}<.05$ ) en hebben minder gedragsproblemen (univariaat: p<.05) dan de overige WO-kinderen. Het leeftijdsverschil tussen de subgroepen biedt onvoldoende verklaring voor deze verschillen: in een MANCOVA op de stresserende kenmerken met leeftijd als covariaat blijven de beide subgroepen van elkaar verschillen.

\section{Subgroep gewenning aan toekomstige uithuisplaatsing ( $n=7$ )}

In totaal noemen 7 ouders als reden voor hun aanmelding dat het gezin op deze wijze kan wennen aan een toekomstige uithuisplaatsing van het verstandelijk gehandicapte kind. Voor het gehandicapte kind zou het goed zijn te leren dat het ergens anders dan in het eigen gezin ook gezellig kan zijn en dat hij of zij zich elders ook op zijn of haar gemak kan voelen. De ouders en de andere kinderen kunnen er op deze wijze eveneens aan wennen dat het gehandicapte kind niet altijd thuis zal blijven wonen. Voor 2 van deze ouders is dit de enige reden voor hun aanmelding bij Weekendopvang. Er zijn geen verschillen tussen deze 7 gezinnen en de overige 57 WO-gezinnen.

\section{Subgroep vertrouwde opvang ( $n=3$ )}

Tenslotte hebben 3 ouders als reden voor hun aanmelding bij de Weekendopvang genoemd dat zij een deskundige en vaste opvang voor het gehandicapte kind in een vertrouwde omgeving hopen te vinden. Deze subgroep is te klein om te kunnen analyseren. 


\subsubsection{Gewenste frequentie}

Van de 58 ouders die hebben aangegeven hoe vaak zij wan de Weekendopvang gebruik willen maken, hopen 26 ouders het gehandicapte kind eens per maand of vaker naar de opvang te mogen brengen, 18 ouders, onder wie alle ouders wier gehandicapte kind enig kind is, én weekend per zes tot acht weken en 14 ouders eens per drie maanden of minder vaak. Met een multiple discriminant analyse is de veronderstelling getoetst dat ouders die zich het meest belast voelen, het meest frequent van de Weekendopvang gebruik willen maken. De ouders zijn in drie groepen ingedeeld op grond van de door hen opgegeven gewenste frequentie van deelname. Alle variabelen uit de blokken $1 \mathrm{t} / \mathrm{m} 8$ zijn als onafhankelijke variabelen ingebracht. Van de twee mogelijke discriminantfuncties is alleen de eerste statistisch significant: $\left(\mathrm{chi}^{2}(5)=17.71 ; \mathrm{p}<.005\right)$. De interpretatie van deze functie is gebaseerd op de gemiddelde scores van de drie groepen op deze functie (naarmate men vaker van de Weekendopvang gebruik wil maken, heeft men een lagere discriminantfunctiescore) en op de correlaties van de onafhankelijke variabelen met deze discriminantfunctie (alleen correlaties met een absolute waarde van $r \geq 20$ zijn bij de interpretatie betrokken).

Ouders willen vaker wan de Weekendopvang gebruik maken naarmate:

(a) het verstandelijk gehandicapte kind minder sociaal redzaam $(r=.55)$ en sociaal vaardig en zelfredzaam ( $r=.52)$ is en meer gedragsproblemen heeft $(r=-.30)$;

(b) de ouders minder zelfwaardering hebben ( $r=39$ ); en

(c) de moeders een hogere opleiding hebben afgerond $(r=-.21)$.

In de gezinnen met meer kinderen willen de ouders bovendien vaker van de Weekendopvang gebruik maken, naarmate:

(d) de relatie tussen het gehandicapte kind en zijn of haar broer(s) en/of zus(sen) slechter is ( $r=.54)$; en

(e) de andere kinderen jonger zijn ( $r=.40)$.

\subsubsection{Samenvatting: Hulpvragers en hulpvragen bij wO}

Weekendopvang beoogt de ouders en de eventuele andere kinderen in het gexin te ondersteunen door hen de kans te geven zo nu en dan een weekend op adem te komen. Aan het onderzoek werken drie projecten Weekendopvang mee. De verstandelijk gehandicapte kinderen die bij deze projecten worden aangemeld, zijn gemiddeld ongeveer 12 jaar oud en zijn vaak het oudste of het middelste kind in het gezin. $\mathrm{Zij}$ hebben een slechtere relatie met hun broer(s) en/of zus(sen) dan kinderen voor wie geen Weekendopvang is aangevraagd. Hoewel zij evenveel stresserende kenmerken hebben als kinderen die niet zijn aangemeld, ervaren hun ouders, zoals verwacht, meer gezinsverstoring en praktische druk en maken zij zich meer bexorgd over de ontwikkeling van de andere kinderen dan ouders die geen opvang voor hun gehandicapte kind aanvragen. Zij voelen zich lichamelijk en geestelijk echter even goed.

Een groot gedeelte van de hulpuragen blijkt aan te sluiten bij de doelstelling van de projecten Weekendopvang. Ouders die zich voor Weekendopvang aanmelden om zelf 
tot rust te komen, woelen zich lichamelijk en geestelijk slechter dan ouders die de opvang om andere redenen aanvragen. Jongere gezinnen vragen Weekendopvang aan om activiteiten te kuninen ondememen die zij met het veelal ernstig gehandicapte kind erbij nauwelijks de moeite waard vinden en om de andere kinderen in het gezin eens aan bod te laten komen. Veel ouders vragen Weekendopvang niet zozeer aan vanwege de belasting die zij zelf ervaren maar vanwege beperkingen in de leefomgeving van het gehandicapte kind, i.c. het ontbreken van voldoende sociale contacten in de situatic thuis. Het zijn vaak de enig kinderen in het gezin en de oudere verstandelijk gehandicapte kinderen die om deze reden bij de projecten worden aangemeld. Weinig ouders vragen Weekendopvang aan met alls enige reden te wennen aan cen toekomstige uithuisplaatsing van het gehandicapte kind. Ouders die zich voor Weekendopvang aanmelden, hopen gemiddeld eens per één of twee maanden van de opvang gebruik te kunnen maken.

\subsection{Besluit: Hulpvragers en hulpvragen bij thuiszorg}

De resultaten in dit hoofdstuk maken duidelijk hoe belastend het leven met een verstandelijk gehandicapt kind is voor ouders die hulp aanvragen en krijgen toegewezen. Ouders die de hulp van Praktisch Pedagogische Gezinsbegeleiding inroepen, voelen zich vóor de aanvang van de hulpverlening zwaarder belast dan ouders die, voor zover zij al pedagogische vragen hebben, daarvoor geen beroep op PPG doen. Dit is uiteindelijk te wijten aan de grotere gedragsproblematiek van het verstandelijk gehandicapte kind in de gezinnen die PPG aanvragen. Gezinnen die geholpen willen worden bij het leren hanteren of oplossen van deze gedragsproblemen, voelen zich binnen de PPG-groep dan ook zwaarder belast dan gezinnen wier hulpvragen betrekking hebben op de ontwikkelingsstimulering van het kind, de interne gezinsrelaties of de relaties van het kind met mensen buiten het gezin.

Opvallend bij de evaluatie van Praktische Thuishulp is het feit dat de zes centrales die aan het onderzoek meewerken, in twee jaar tijd niet meer dan 25 aanvragen voor hulp hebben kunnen honoreren. Deze ouders hebben, zoals verwacht, een hoger opleidingsniveau en ervaren meer praktische druk dan ouders die zich bij eventuele praktische problemen niet tot Praktische Thuishulp wenden. Hun gehandicapte kind heeft gemiddeld genomen minder sociale vaardigheden en een geringere zelfredzaamheid. Oppas en bezigheidsbegeleiding zijn de meest aangewraagde hulpsoorten, terwijl taakverlichting vaak als reden voor de aanvraag genoemd wordt.

Ouders die Weekendopvang aanvragen, ervaren, zoals verwacht, meer concrete problemen dan ouders die hun gehandicapte kind niet aanmelden voor opvang gedurende de weekends. Opmerkelijk hierbij is dat beide groepen niet verschillen in de ernst van de determinanten van deze problemen. Een groot gedeelte van de redenen van ouders om zich bij de projecten Weekendopvang aan te melden, betreft de ondersteuning van de ouders en de andere kinderen in het gezin. Daamaast hopen veel ouders het (dreigende) sociale isolement van hun gehandicapte kind te kunnen doorbreken door het kind zo nu en dan een weekend met leeftijd- en niveaugenoten te laten logeren in cen vertrouwde omgeving. 


\section{Resultaten III: Effecten en oordelen}

Hoofdstuk 9 presenteert de resultaten van de analyses die zijn uitgevoerd om na te gaan welke effecten de drie hulpvormen na éen jaar hebben op de stress van de ouders en de determinanten daarvan. Daarnaast worden de oordelen van de ouders over de vormgeving en de inhoud van de hulp besproken. De gegevens worden per hulpvorm weergegeven in de paragrafen $9.2 \mathrm{t} / \mathrm{m} \mathrm{9.4}$. Hieraan voorafgaand wordt in 9.1 een beschrijving gegeven van de controlegroep in de nameting.

\subsection{De controlegroep}

Bij de analyses ten aanzien van de effecten van de hulp zijn 47 van de 60 gezinnen uit de oorspronkelijke controlegroep betrokken (zie 6.2). Vergelijkingen op de variabelen uit de blokken $1 \mathrm{t} / \mathrm{m} 8$ in de voormeting laten zien dat deze 47 gezinnen toen in geen enkel opzicht afweken van de 13 gezinnen uit de controlegroep die niet bij de analyses ten aanzien van de effecten van de hulp zijn betrokken. Om deze reden zijn de scores op de nameting van deze 47 gezinnen (zie de eerste kolom in tabel 9.1 voor de variabelen waarover voor eén of meer hulpvormen hypotheses zijn opgesteld en bijlage E, tabel $1 \mathrm{en} 2$ voor de overige variabelen) te vergelijken met de scores op de voormeting in de eerste kolom van tabel 8.1 respectievelijk bijlage D, tabel 1 en 2.

In de controlegroep hebben enkele veranderingen plaatsgehad tussen de voor- en de nameting. MANOVA's op de verschilscores en gepaarde Student's t-toetsen (zie 6.3.2) laten zien dat de vaardigheden ten aanzien van sociaal gedrag en zelfredzaamheid van de verstandelijk gehandicapte kinderen zijn toegenomen (multivariate $F(4,38)=2.88$; $p<.05$; univariaat: $p<.05$ ). Dit komt, zoals uit een MANCOVA blijkt, doordat zij gemiddeld een jaar ouder zijn geworden. Tevens is de relatie tussen het gehandicapte kind en zijn of haar broer(s) en/of zus(sen) verslechterd $(\mathrm{t}(39)=-2.21$; p<.05, twee-zijdig). Dit is niet te verklaren wit het feit dat zij ouder zijn geworden. 
Zoals verwacht, hebben zich geen veranderingen voorgedaan in de stress van de ouders noch in de determinanten daarvan.

Tabel 9.1

Gemiddelden en standaarddeviaties van de variabelen in de blokken 1,2 en $5 \mathrm{t} / \mathrm{m} 8$ van de controle - en de hulpverleningsgroepen: nameting

\begin{tabular}{|c|c|c|c|c|}
\hline \multirow[b]{2}{*}{ Variabelen } & \multicolumn{4}{|c|}{ Groepen } \\
\hline & $\begin{array}{l}\text { Controle } \\
(n=47)\end{array}$ & $\begin{array}{l}\text { PPG } \\
(=48)\end{array}$ & $\begin{array}{l}\text { PT } \\
(n=11)\end{array}$ & $\begin{array}{l}\text { WO } \\
(\mathrm{n}=42)\end{array}$ \\
\hline \multicolumn{5}{|c|}{ Blok 1: Stresserende kenmerken verstandelijk gehandicapt kind } \\
\hline 1. Gedragsproblemen & $\begin{array}{l}1.51 \\
(.47)\end{array}$ & $\begin{array}{l}1.88 * * * \\
(.47)\end{array}$ & $\begin{array}{l}1.58 \\
(.37)\end{array}$ & $\begin{array}{l}1.58 \\
(.48)\end{array}$ \\
\hline 2. Sociale redxaamheid & $\begin{array}{l}2.75 \\
(.38)\end{array}$ & $\begin{array}{l}2.57^{*} \\
(.40)\end{array}$ & $\begin{array}{l}2.74 \\
(.36)\end{array}$ & $\begin{array}{l}2.74 \\
(.39)\end{array}$ \\
\hline $\begin{array}{l}\text { 3. Sociale vaardigheden en } \\
\text { zelfredzaamheid }\end{array}$ & $\begin{array}{l}2.36 \\
(.56)\end{array}$ & $\begin{array}{l}2.24 \\
(.40)\end{array}$ & $\begin{array}{l}2.14 \\
(.46)\end{array}$ & $\begin{array}{l}2.27 \\
(.55)\end{array}$ \\
\hline 4. Lichamelijke gezondheid & $\begin{array}{l}2.45 \\
(.69)\end{array}$ & $\begin{array}{l}2.44 \\
(.61)\end{array}$ & $\begin{array}{l}1.91 * * \\
(.70)\end{array}$ & $\begin{array}{l}2.41 \\
(.70)\end{array}$ \\
\hline \multicolumn{5}{|l|}{ Bllok 2: Kenmerken van de ouders } \\
\hline 5. Zelfwaardering & $\begin{array}{l}2.57 \\
(.49)\end{array}$ & $\begin{array}{l}2.38^{*} \\
(.50)\end{array}$ & $\begin{array}{l}2.84^{*} \\
(20)\end{array}$ & $\begin{array}{l}2.61 \\
(.39)\end{array}$ \\
\hline \multicolumn{5}{|l|}{ Blok 5: Concrete problemen } \\
\hline 6. Gexinswerstoring & $\begin{array}{l}1.46 \\
(.52)\end{array}$ & $\begin{array}{l}1.79 * \\
(.59)\end{array}$ & $\begin{array}{l}1.71 \\
(.31)\end{array}$ & $\begin{array}{l}1.63 \\
(.52)\end{array}$ \\
\hline 7. Praktische druk & $\begin{array}{l}1.46 \\
(.62)\end{array}$ & $\begin{array}{l}1.68 \\
(.60)\end{array}$ & $\begin{array}{l}1.86^{*} \\
(.28)\end{array}$ & $\begin{array}{l}1.68 * \\
(.60)\end{array}$ \\
\hline 8. Problemen m.b.t. de partner & $\begin{array}{l}1.42 \\
(.46)\end{array}$ & $\begin{array}{l}1.58 \\
(.57)\end{array}$ & $\begin{array}{l}1.45 \\
(.45)\end{array}$ & $\begin{array}{l}1.44 \\
(.39)\end{array}$ \\
\hline $\begin{array}{l}\text { 9. Zorgen over de ontwikkeling } \\
\text { var de anderen kinderen }\end{array}$ & $\begin{array}{l}1.25 \\
(.39)\end{array}$ & $\begin{array}{l}1.37 \\
(.52)\end{array}$ & $\begin{array}{l}1.44 \\
(.44)\end{array}$ & $\begin{array}{l}1.34 \\
(.40)\end{array}$ \\
\hline \multicolumn{5}{|c|}{ Blok 6: Psychosomatisch onwellbevinden } \\
\hline $\begin{array}{l}\text { 10. Paychosomatisch } \\
\text { onwelbevinden }\end{array}$ & $\begin{array}{l}1.65 \\
(.52)\end{array}$ & $\begin{array}{l}1.85 \text { * } \\
(.57)\end{array}$ & $\begin{array}{l}1.53 \\
(.22)\end{array}$ & $\begin{array}{l}1.60 \\
(.37)\end{array}$ \\
\hline \multicolumn{5}{|l|}{ Blok 7: Coping } \\
\hline 11. Depressief reactiepatroon & $\begin{array}{l}1.99 \\
(.39)\end{array}$ & $\begin{array}{l}2.23^{*} \\
(.60)\end{array}$ & $\begin{array}{l}2.12 \\
(.52)\end{array}$ & $\begin{array}{l}2.03 \\
(.28)\end{array}$ \\
\hline $\begin{array}{l}\text { Blok 8: Sociale steun } \\
\text { 12. Sociale isolatie }\end{array}$ & $\begin{array}{l}1.45 \\
(.54)\end{array}$ & $\begin{array}{l}1.64 \\
(.62)\end{array}$ & $\begin{array}{l}1.62 \\
(.62)\end{array}$ & $\begin{array}{l}1.42 \\
(.45)\end{array}$ \\
\hline
\end{tabular}

Verschil met de controlegroep:

${ }^{*} \mathrm{p}<.05$, een-zijdig. ${ }^{* *} \mathrm{p}<.01$, een-zijdig. ${ }^{* * *}$ p<.001, een-zijdig. 


\subsection{Praktisch Pedagogische Gezinsbegeleiding}

\subsubsection{Beschrijving van de PPG-groep in de nameting}

In totaal vulden 48 van de oorspronkelijke 58 PPG-ouders de vragenlijst in na afloop van Praktisch Pedagogische Gezinsbegeleiding (zie 6.2). Vergelijkingen op de scores in de voormeting tussen deze 48 ouders en de 10 ouders die de vragenlijst niet voor een tweede keer invulden, laten alleen zien dat de laatstgenoemde ouders ten tijde van de voormeting vaker gebruik maakten van de copingstijlen "vermijding" en "palliatieve reactie" (multivariate $\mathrm{F}(5,48)=2.00 ; \mathrm{p}<1$ 10; univariaat: $\mathrm{p}<.05$ respectievelijk p<.10). Dit betekent onder andere dat de nametingsscores van de PPGgroep (zie de tweede kolom van tabel 9.1 respectievelijk bijlage E, tabel 1 en 2) op alle andere punten met de voormetingsscores te vergelijken zijn (zie tabel 8.1 en bijlage $\mathrm{D}$, tabel 1 en 2 ).

Evenals in de voormeting blijkt de PPG-groep ook in de nameting op enkele punten van de controlegroep af te wijken (zie bijlage E, tabel 1 en 2). In de PPG-groep zijn meer jongens en minder meisjes, zijn meer moeders alleenstaand en zijn de gezinnen jonger dan in de controlegroep. Voorts is in de PPG-groep de sociale klasse lager, het gehandicapte kind valker enig kind en minder vaak het jongste kind en de relatie tussen het gehandicapte kind en zijn of haar broer(s) en/of zus(sen) slechter (zie ook 8.2.1 en 8.2.2).

\subsubsection{Effecten}

Ten aanzien van de effecten van Praktisch Pedagogische Gezinsbegeleiding zijn zes hypotheses opgesteld (zie 5.1 en 7.4.2):

In gezinnen die Praktisch Pedagogische Gezinsbegeleiding hebben gehad:

Hypothese 2-1: heeft zich een grotere afname in de stresserende kenmerken van het verstandelijk gehandicapte kind voorgedaan, met name wat de gedragsproblematiek en sociale redzaamheid betreft;

Hypothese 2-2: hebben de ouders meer zelfwaardering gekregen;

Hypothese 2-3: heeft een grotere reductie in de concrete problemen van de ouders plaatsgehad;

Hypothese 2-4: heeft een grotere toename in het psychosomatisch welbevinden van de ouders plaatsgehad;

Hypothese 2-5: zijn de ouders minder vaak de copingstijl "depressief reactiepatroon" gaan gebruiken; en

Hypothese 2-6: heeft zich bij de ouders een grotere afname in de gevoelens van sociale isolatie voorgedaan. dan in gezinnen die geen Praktisch Pedagogische Gezinsbegeleiding hebben gehad.

De invloed van PPG is eerst voor de totale PPG-groep nagegaan (9.2.2.1) en vervolgens voor elk van de PPG-subgroepen (9.2.2.2). 


\subsubsection{Effecten voor de totale PPG-groep}

De effecten van PPG zijn in drie analyse-rondes bestudeerd (zie 6.3.2). Uit de eerste ronde, waarin is nagegaan of er binnen de totale PPG-groep tussen de vooren de nameting veranderingen zijn opgetreden in de variabelen waarop de hypotheses betrekking hebben, blijkt dat er veranderingen hebben plaatsgehad in de stresserende kenmerken van het gehandicapte kind, de zelfwaardering van de ouders, hun psychosomatisch onwelbevinden en hun gevoelens van sociale isolatie (zie tabel 9.2 onder (A)). Deze veranderingen betreffen in alle gevallen verbeteringen. Vergelijkbare anallyses in de controlegroep hebben nauwelijks verbeteringen in deze opzichten laten zien (zie 9.1).

Tabel 9.2

Analyse-resultaten ten aanzien van de effecten van Praktisch Pedagogische Gezinsbegeleiding

\section{Resultaten}

(A) PPG-groep:

Verschillen voor- nameting

Hypotheses:

(B) PPG-controlegroep: Verschillen met controle voor initięle verschillem

2-1. Stresserende kenmerken verstandelijk gehandicapt kind

$\begin{array}{ll}\text { (A) } F(4,36)=6.39 ; & \text { (B) }<.001 \\ \text { univariaat: } & \text { univariaat: } \\ \text { gedragsproblemen: } p<.01 & \text { n.s. } \\ \text { sociale redzaamheid: } p<.001 & p<.05 \\ \text { sociale vaardigheden en } & \\ \text { zelfredzaamheid: } p<.001 & p<10 \\ \text { (A) } 1(46)=1.88 ; p<.05 \text {, een-zijdig } & \text { (B) n.s. }\end{array}$

\section{2-2. Zelfwaardering}

(A) $\mathrm{t}(46)=1.88 ; \mathrm{p}<.05$, een-zijdig

(B) n.s.

2-3. Concrete problemen

a. Gezinsverstoring, praktische duk, problemen m.b.t. de partner

(A) n.s.

(B) n.s.

b. Zorgen over de ontwikkeling van de andere kinderen

(A) n.s.

(B) n.s.

2-4. Psychosomatisch onwelbevinden
(A) $\mathrm{t}(46)=1.84 ; p<.05$, een-zijdig
(B) n.s.

$2-5$. Depressief reactiepatroon (A) n.s.

(B) n.\%.

2-6. Socialle isolatie

(A) $\mathrm{t}(47)=-1,90 ; \mathrm{p}<, 05$, een-zijdig

(B) n.s.

In de tweede analyse-ronde zijn ter toetsing van de hypotheses de scores van de PPG-groep in de nameting met die van de controlegroep vergeleken, onder constanthouding van de initièle verschillen (zie 6.3.2). Uit het overzicht van de resultaten van deze (M)ANCOVA's in tabel 9.2 onder (B) blijkt dat de hypotheses $2-2 \mathrm{t} / \mathrm{m}$ 2-7 verworpen moeten worden. Hypothese $2-1$ wordt gedeeltelijk verworpen: de verstandelijk gehandicapte kinderen in de PPG-groep zijn meer sociaal redzaam geworden en hebben iets meer vaardigheden ten aanzien van sociaal gedrag en zelfredzaamheid ontwikkeld dan de kinderen in de controlegroep. De afname in hun gedragsproblemen is niet aantoonbaar groter. In de MANCOVA op de drie genoem- 
de stresserende kenmerken is overigens ook de leeftijd van de kinderen in de nameting als covariaat opgenomen (zie ook 8.2.2).

In de derde analyse-ronde is nagegaan in welke opzichten de PPG-groep na afloop van een jaar hulpverlening (nog) van de controlegroep verschilt: Uit de tweede kolom van tabel 9.1 wordt duidelijk dat de verstandelijk gehandicapte kinderen in de PPG-groep na een jaar hulpverlening meer gedragsproblemen en een geringere sociale redzaamheid hebben dan de kindenen in de controlegroep, terwijl hun ouders minder zelf waardering hebben, meer gezinsverstoring ervaren, vaker een depressieve copingstijl hanteren en zich in psychosomatisch opzicht slechter voelen dan de ouders in de controlegroep.

Een aantal verschillen die voorafgaand aan de hulpverlening tussen de PPG-groep en de controlegroep bestonden (zie tabel 8.1), blijken na een jaar Praktisch Pedagogische Gezinsbegeleiding niet meer aantoonbaar te zijn. De verstandelijk gehandicapte kinderen in de PPG-groep zijn niet langer minder sociaal vaardig en zelfredzaam, hun ouders ervaren niet langer meer praktische druk en meer problemen met betrekking tot hun partner, zij maken zich niet langer meer bezorgd over de ontwikkeling van hun andere kinderen en zij voelen zich niet langer meer sociaal geïsoleerd. De andere verschillen lijken minder pregnant te zijn dan voorafgaand aan de hulpverlening. (M)ANCOVA's maken, evenals in de voormeting (zie 8.2.2), duidelijk dat de verschillen na een jaar PPG niet door demografische variabelen worden gemedieerd, maar wel door de belangrijkste correlaat respectievelijk de determinanten van de achtereenvolgende variabelen. Dit betekent dat ook na afloop van een jaar hulpverlening de grotere mate van stress bij de ouders in de PPG-groep uiteindelijk te verklaren is vanuit de grotere gedragsproblematiek van de verstandelijk gehandicapte kinderen in deze groep. De gedragsproblematiek is weliswaar iets afgenomen, maar deze afname kan, zoals gebleken is, niet eenduidig aan de hulpverlening worden toegeschreven.

\subsubsection{Effecten per subgroep}

Voorafgaand aan de hulpverlening zijn vier subgroepen onderscheiden op grond van de hulpvragen van de ouders (zie 8.2.3). Na afloop van de hulp is ellke PPGsubgroep vergeleken met de overige $P P G$-gezinnen om na te gaan in hoeverre de subgroepen in gelijke mate van de hulp hebben geprofiteerd. De analyses zijn in dezelfde drie rondes uitgevoerd als die ten aanzien van de effecten van de hulp op de totale PPG-groep (zie 6.3.2 en 9.2.2.1). Bestudeerd zijn de variabelen waarop de hypotheses $2-1 \mathrm{t} / \mathrm{m} \mathrm{2-6}$ betrekking hebben. Voor zover er in de voormeting ook op andere punten verschillen tussen de subgroepen bestonden, zijn deze eveneens bij de analyses betrokken.

\section{Subgroep gedragsproblemen ( $n=29)$}

In de subgroep "gedragsproblemen" zijn tussen de voor- en de nameting verbeteringen opgetreden in:

(a) de stresserende kenmerken van het gehandicapte kind (multivariate $\mathrm{F}(4,22)=3.13 ; \mathrm{p}<.05)$, met name in het gedrag (univariaat: $\mathrm{p}<.05$ ), de sociale 
redzaamheid (univariaat: $p<.05$ ) en de sociale vaardigheden en zelfredzaamheid (uniwariaat: $\mathrm{p}<.01$ ); en

(b) de zelfwaardering van de ouders ( $t(28)=1.80 ; p<.05$, een-zijdig).

Hoewel uit de (M)ANCOVA's in de tweede analyse-ronde blijkt dat deze verbeteringen niet aantoonbaar groter zijn dan die bij de overige PPG-gezinnen, verschillen de beide subgroepen na afloop van de hulpverlening alleen nog in de emst van de stresserende kenmerken van het gehandicapte kind (multivariate $F(4,43)=4.44$; p<.01). De kinderen in de subgroep "gedragsproblemen" hebben iets meer gedragsproblemen (univariaat: $p<10$ ) en meer vaardigheden ten aanzien van sociaal gedrag en zelfredzaamheid (univariaat: $p<.01$ ) dan de overige PPG-kinderen. De overige verschillen uit de voormeting, namelijk ten aanzien van de concrete problemen, de copingstijl "vermijding" en het aantal mensen dat de ouders emotioneel ondersteunt, zijn na afloop van de hulp niet meer aan te tonen.

\section{Subgroep ontwikkelingsstimulering $(n=21)$}

Evenals in de voormeting zijn de verstandelijk gehandicapte kinderen in de subgroep "ontwikkelingsstimulering" na een jaar PPG gemiddeld jonger dan de overige PPGkinderen ( $M=5.5$ jaar respectievelijk $M=10$ jaar; $t(46)=-2.69 ; p<, 01$, een-zijdig). In de subgroep "ontwikkelingsstimulering" zijn verbeteringen opgetreden in:

(a) de stresserende kenmerken van het verstandelijk gehandicapte kind (multivariate $F(4,11)=5.90 ; p<.01$ ), met name wat betreft het gedrag (univariaat: $p<.05$ ), de sociale redzaamheid (univariaat: $p<01$ ) en de sociale vaardigheden en zelfredzaamheid (univariaat: $\mathrm{p}<.001$ );

(b) de zelfwaardering van de ouders (t(19) $=2.08 ; \mathrm{p}<.05$, een-zijdig); en

(c) het psychosomatisch welbevinden van de ouders $(t(19)=-1.39 ; p<.10$, eenzijdig).

De subgroep "ontwikkelingsstimulering" heeft echter niet aantoonbaar meer dan de overige PPG-gezinnen van de hulpverlening geprofiteerd, zoals de (M)ANCOVA's in de tweede analyse-ronde laten zien. $\mathrm{Na}$ afloop van de hulpverlening hebben de verstandelijk gehandicapte kinderen in de subgroep "ontwikkelingsstimulering" nog steeds meer stresserende kenmerken dan de overige PPG-kinderen (multivariate $F(4,43)=3.93$; $p<.01$ ). Vooral hun lichamelijke gezondheid is slechter (univariaat: $p<.01)$. Dit verschil is niet toe te schrijven aan hun jongere leeftijd. Voorts voelen de ouders zich in lichamelijk en geestelijk opzicht beter dan de overige PPG-ouders $(t(46)=-1.46 ; p<.05$, een-zijdig), terwijl zij zich evenals in de voormeting minder sociaal geirsoleerd voelen $(t(46)=-2.03 ; p<.05$, een-zijdig).

\section{Subgroep omgangsproblemen binnen het gezin ( $n=15)$}

De ouders in de subgroep "omgangsproblemen binnen het gezin" zijn zich tussen de voor - en de nameting minder sociaal geïsoleerd gaan voelen $(t(14)=-1.88 ; p<.05$, cen-zijdig). Voor het overige zijn geen veranderingen geconstateerd in deze subgroep. Bij de resterende 33 PPG-gezimnen is de sociale isolatie niet afgenomen, maar hebben de verstandelijk gehandicapte kinderen na afloop van de hulp minder stresserende kenmerken dan zij in de voormeting hadden (multivariate $F(4,24)=6.36$; $p<.001$ ). Zij hebben minder gedragsproblemen (univariaat: $p<.01$ ), een grotere mate 
van sociale redzaamheid (univariaat: $p<.01$ ) en meer vaardigheden ten aanzien van sociaal gedrag en zelfredzaamheid (univariaat: $p<001$ ).

De subgroep "omgangsproblemen binnen het gezin" heeft niet meer of minder van de hulpverlening geprofiteerd dan de overige PPG-gezinnen, zoals de (M)ANCOVA's laten zien. $\mathrm{Na}$ afloop van de hulpverlening voelen de ouders in deze subgroep zich, evenals vór de hulp, meer sociaal geïsoleerd dan de overige gezinnen $(t(46)=2.12$; $\mathrm{p}<.05$, een-zijdig). Voorts is er in tegenstelling tot voorafgaand aan de hulpverlening een verschil in de emst van de concrete problemen van de ouders (multivariate $F(3,37)=3.04 ; p<.05)$. De ouders in de subgroep "omgangsproblemen binnen het gezin" ervaren meer problemen met betrekking tot de partner (univariaat: $p<.01$ ), meer gezinsverstoring (univariaat: $p<.05$ ) en meer praktische druk (univariaat: $p<.10$ ) dan de overige PPG-ouders. Het feit dat er geen afname heeft plaatsgehad in de stresserende kenmerken van de gehandicapte kinderen, heeft de concrete problemen van de ouders in deze subgroep waarschijnlijk doen toenemen. De resultaten van een MANCOVA op de concrete problemen waabij gecontroleerd is voor eventuele verschillen in de stresserende kenmerken van de gehandicapte kinderen, wijzen in deze richting.

\section{Subgroep sociale vaardigheden $(n=11)$}

In de subgroep "sociale vaardigheden" hebben geen aantoonbare veranderingen plaatsgehad tussen de voor- en de nameting. Deze subgroep heeft dan ook niet aantoonbaar meer profijt van de hulpverlening gehad dan de overige PPG-gezinnen. $\mathrm{Na}$ atloop van de hulp wijkt de subgroep "sociale vaardigheden" evenmin als in de voormeting van de overige PPG-gezinnen af.

\subsubsection{Samenvatting: Effecten van PPG}

Praktisch Pedagogische Gezinsbegeleiding heeft een deel van de belasting die de ouders ervoeren toen zij zich bij de afdelingen PPG aanmeldden, kunnen reduceren. Als gevolg van de hulpverlening zijn de sociale redzaamheid en de vaardigheden ten aanzien van sociaal gedrag en zelfredzaamheid van de verstandelijk gehandicapte kinderen aanzienlijk toegenomen. De overige verbeteringen, in de zelfwaardering van de ouders, hun gevoelens van sociale isolatie, concrete problemen en psychosomatisch onwelbevinden, zijn niet ondubbelzinnig aan de hulpverlening toe te schrijven. Dit is wellicht te wijten aan het feit dat de hulpverlening niet in staat is gebleken de gedragsproblematiek van de verstandelijk gehandicapte kinderen, uiteindelijk de belangrijkste determinant van de stress van de ouders, in voldoende mate te reduceren.

Het algemene beeld van de effecten van PPG kan nader gepreciseerd worden als rekening gehouden wordt met de aard van de hulpvragen. Dan lijken ouders die PPG aanvroegen om geholpen te worden bij de gedragsproblemen van het gehandicapte kind en ouders die hulp wilden bij de stimulering van de ontwikkeling van het kind, het meest van de hulp te hebben geprofiteerd. Bij beide subgroepen zijn verbeteringen in de stresserende kenmerken van het gehandicapte kind en de zelfwaardering van de ouders opgetreden. Deze hebben een bijdrage geleverd aan de afname van de 
stress van de ouders. Ouders met vragen omtrent de omgang van het gehandicapte kind met de overige gezinsleden en ouders die PPG aanvroegen om geholpen te worden bij de ontwikkeling van de sociale vaardigheden van het gehandicapte kind, lijken minder van de hulp geprofiteerd te hebben. De ouders in de subgroep "omgangsproblemen binnen het gezin" lijken na afloop van de hulp zelfs meer concrete problemen te ervaren dan voorafgaand aan de hulpverlening, wellicht ondat er geen afname in stresserende kenmerken van de gehandicapte kinderen in deze subgroep heeft plaatsgehad. In de subgroep "sociale vaardigheden" lijkt tenslotte niets te zijn veranderd.

\subsubsection{Oordelen}

Aan de PPG-ouders zijn vragen gesteld over enkele aspecten van de vormgeving van Praktisch Pedagogische Gezinsbegeleiding, de mate waarin hun vragen met behulp van Praktisch Pedagogische Gezinsbegeleiding zijn beantwoord en hun algemene satisfactie met de hulp (zie 6.1.2). De gegevens worden in 9.2.3.1 t/m 9.2.3.3 weergegeven.

\subsubsection{Vormgeving}

\section{Duur en frequentie}

Van de 48 ouders rapporteren 6 ouders korter dan een half jaar Praktisch Pedagogische Gezinsbegeleiding gehad te hebben, 14 ouders ongeveer een half jaar, 6 ouders tussen een half jaar en een jaar, 15 ouders ongeveer een jaar en de resterende 7 ouders langer dan een jaar. In totaal zijn 6 ouders van mening dat de hulp langer had mogen duren. De overige 42 ouders zijn tevreden over de duur van PPG. Er is geen verband tussen de gerapporteerde duur en het oordeel van de ouders daarover.

De pedagogisch werkende bezocht 26 van de 48 gezinnen eens per week en 3 gezinnen vaker. Bij 15 gezinnen kwam de pedagogisch werkende én keer per twee weken en bij 4 gezinnen minder vaak dan éen keer per twee weken. Slechts 1 gezin vond de frequentie te laag; de overige 47 gezinnen menen dat de pedagogisch werkende vaak genoeg bij hen kwam. Naarmate de hulpverlening langer duurde, $k w a m$ de pedagogisch werkende minder frequent $(r=-.26 ; p<.05$, een-zijdig).

In de subgroep "omgangsproblemen binnen het gezin" duurdle PPG langer dan bij de resterende gezinnen $(\mathrm{t}(46)=2.24 ; \mathrm{p}<.05$, twee-zijdig). In de andere subgroepen duurde de hulp gemiddeld genomen even lang. De hulpverlening duurde tevens langer naarmate het gehandicapte kind bij de aanvang van de hulp meer gedragsproblemen had ( $r=.26 ; p<.05$, een-zijdig) en minder sociaal redzaam was ( $r=-.26$; $\mathrm{p}<.05$, een-zijdig), de relatie tussen het kind en zijn of haar broer(s) en/of zus(sen) slechter was ( $r=-.40 ; p<.01$, een-zijdig), de ouders zich meer sociaal geïsoleerd voelden ( $r=.24 ; p<.05$, een-zijdig) en minder zelfwaardering hadden $(r=-.19 ; p<.10$, een-zijdig). De frequentie waarmee de pedagogisch werkende de gezinnen bezocht, was niet afhankelijk van de hulpvragen of de emst van de problematiek binnen de gezinnen bij de aanvang van de hulp. 


\section{Negen aspecten van de vormgeving}

De gegevens in tabel 9.3 maken duidelijk dat de ouders zeer positief zijn over alle negen vormgevingsaspecten die hun zijn voorgelegd. Het totale oordeel over de wijze waarop Praktisch Pedagogische Gezinsbegeleiding is uitgevoerd, een score geconstrueerd door sommatie en middeling van de scores op de afzonderlijke vormgevingsaspecten, is dan ook zeer positief.

Tabel 9.3

Aantal ouders die zeer tor niet tevreden zijn over de vormgeving van Praktisch Pedagogische Gezinsbegeleiding ( $n=48$ )

Tevredenheid

1. Contact ouder - p.w.

2. Contact P.W. - k.W.h.

3. Contact p.w. - overige gezinsleden

4. Wekelijkse gesprekken

5. Evaluatiegesprekken

6. Schriftelijke verslagen

7. Praktische aanwijzingen

8. Opdrachten

9. Werken volgens werkplan

10. Totaal oordee!

$\begin{array}{ll}45 & 3 \\ 43 & 5 \\ 42 & 3 \\ 45 & 3 \\ 43 & 4 \\ 39 & 4 \\ 38 & 4 \\ 36 & 8 \\ 34 & 6 \\ 45 & 3\end{array}$

Noot. P.w.= pedagogisch werkende. K.v.h.= kind met een verstandelijke handicap.

\subsubsection{Inhoud}

De hulpvragen die de ouders bij de aanvang van PPG hadden, zijn na de hulp in dezelfde bewoordingen aan hen voorgelegd. Hun is gevraagd in welke mate PPG hen geholpen heeft deze vragen te beantwoorden. De resultaten staan in tabel 9.4.

Tabel 9.4

Aantal ouders wier hulpvragen met behulp van Praktisch Pedagogische Gezinsbegeleiding helemaal tot niet zijn beantwoord $(n=48)$

Hulpvragen beantwoord

1. Gedragsproblemen $(\mathrm{n}=27)$

2. Ontwikkelingsstimulering $(\mathrm{n}=20)$

3. Omgangsproblemen binnen het gezin $(n=15)$

4. Sociale vaardigheden $(n=11)$

5. Anders ( $n=9)$

18

9

9

5 
Gezien de variatie in de antwoorden, is binnen de eerste drie subgroepen nagegaan welke ouders meer en welke ouders minder van de hulp geprofiteerd zeggen te hebben. Aangezien slechts 2 van de ouders in de subgroep "sociale vaardigheden"' aangeven dat hun hulpviaag grotendeels is beantwoord, zijn in deze subgroep geen analyses uitgevoerd, evenmin als in de vijfde subgroep, die vanwege de diversiteit van de hulpvragen niet als een groep wordt beschouwd (zie 8.2.3).

Ten eerste is met Student's t-toetsen nagegaan of de duur en de frequentie van de hulpverlening van invloed is geweest op de mate waarin de hulpvragen van de ouders zijn beantwoord. Dit blijkt niet het geval te zijn.

Ten tweede is nagegaan in hoeverre de stress van de ouders van invloed is geweest op de mate waarin de hulpvragen zijn beantwoord. Hierbij zijn drie veronderstellingen getoetst, namelijk:

(1) Is de hulpvraag van de ouders beter beantwoord naarmate de ouders zich voorafgaand aan de hulpverlening minder belast voelden? Deze veronderstelling komt voort uit de gedachte dat het succes van Praktisch Pedagogische Gezinsbegeleiding mede afhankelijk is van de inzet van de ouders (zie 5.1). Verwacht wordt dat de ouders zich meer kunnen inzetten om de benodigde veranderingen te bewerkstelligen naarmate de stress in het gezin geringer is.

(2) Ervaren de ouders wier hulpvraag geheel of grotendeels is beantwoord, na afloop van de hulpverlening inderdaad minder stress dan de ouders die aangeven dat hun hulpvraag niet of nauwelijks is beantwoord?

(3) Hebben bij de ouders wier hulpvraag geheel of grotendeels is beantwoord, meer positieve veranderingen in hun stressbeleving en de determinanten daarvan plaatsgehad tussen de voor- en de nameting dan bij de ouders wier hulpvraag niet of nauwelijks is beantwoord?

Bij deze drie veronderstellingen zijn de ouders wier hulpvraag geheel of grotendeels is beantwoord, in de stress die zij ervaren en de determinanten daarvan telkens vergeleken met de ouders wier hulpvraag niet of slechts voor een klein gedeelte is beantwoord. Voor de toetsing van de eerste twee veronderstellingen zijn MANOVA's gebruikt voor zover de vergelijkingen bloksgewijs plaatsvonden en Student's ttoetsen voor zover de vergelijkingen éen afhankelijke variabele betroffen. Bij de eerste veronderstelling zijn de analyses uitgevoerd op de scores in de voormeting, bij de tweede op de scores in de nameting. Voor de toetsing van de derde veronderstelling zijn (M)ANCOVA's uitgevoerd op de scores in de nameting met de betreffende scores in de voormeting als covariaten. Alleen significante bevindingen worden weergegeven.

\section{Subgroep gedragsproblemen}

Voorafgaand aan de hulpverlening ervoeren de 18 ouders wier hulpvragen op het gebied van de gedragsproblemen van het gehandicapte kind geheel of grotendeels zijn beantwoord, op twee punten minder stress dan de 9 ouders wier hulpvragen op dit terrein niet of nauwelijks beantwoord zijn. Zij maakten zich minder bezorgd over de ontwikkeling van hun andere kinderen $(t(16)=-2.83 ; p<.01$, een-zijdig) en lijken 
zich in psychosomatisch opzicht beter te hebben gevoeld. Dit laatste kan niet worden getoetst aangezien in beide groepen geen variantie in de scores op deze variabele bestaat: alle 18 ouders wier hulpvragen helemaal of grotendeels zijn beantwoord, hebben de laagste score, namelijk 1 , terwijl alle overige ouders een 2 scoren op deze variabele (range: 1-4; zie Bijlage $A$, tabel 5). Na afloop van de hulp maken de ouders wier hulpvragen zijn beantwoord, zich nog steeds minder bezorgd over de ontwikkeling van de andere kinderen $(t(18)=-2.54 ; p<.01$, een-zijdig), terwijl zij zich eveneens geestelijk en lichamelijk beter zijn blijven voelen $(t(25)=-3.17 ; p<.01$, een-zijdig).

De ouders wier hulpvragen zijn beantwoord, verschilden voorafgaand aan de hulpverlening niet van de overige 9 ouders in hun zelfwaardering, copingstijlen en gevoelens van sociale isolatie. $\mathrm{Na}$ afloop van de hulp blijken de eerste 18 ouders echter meer zelfwaardering te hebben $(t(25)=2.92 ; p<.01$, een-zijdig), minder vaak een depressieve copingstijl te gebruiken $(t(25)=-1.66 ; p<.05$, een-zijdig) en zich minder sociaal geïsoleerd te voelen $(t(25)=-3.57 ; \mathrm{p}<.001$, een-zijdig). ANCOVA's tonen aan dat de ouders wier hulpvragen zijn beantwoord, tussen de voor- en de nameting inderdaad meer zelfwaardering hebben gekregen $(F(2,24)=9.68 ; p<.01)$, minder vaak de copingstijl "depressief reactiepatroon" zijn gaan gebruiken $(F(2,24)=6.28 ; \quad p<.05)$ en zich minder sociaal geïsoleerd zijn gaan voelen $(F(2,24)=16.33 ; p<.001)$ dan de overige ouders.

\section{Subgroep ontwikkelingsstimulering}

Voorafgaand aan de hulpverlening ervoeren de 11 ouders wier hulpvragen op het gebied van de stimulering van het gehandicapte kind helemaal of grotendeels zijn beantwoord, op drie punten minder stress dan de ouders wier hulpvragen op dit gebied niet of nauwelijks zijn beantwoord. $\mathrm{Zij}$ maakten zich minder bezorgd over de ontwikkeling van hun andere kinderen $(\mathrm{t}(11)=-2.62 ; \mathrm{p}<.01$, een-zijdig), voelden zich minder sociaal geïsoleerd $(t(18)=-2.15 ; p<.05$, een-zijdig) en lijken zich geestelijk en lichamelijk beter te hebben gevoeld, hoewel dit laatste niet getoetst kan worden gezien de afwezigheid van variantie in hun scores $(M=1, S D=0$ versus $M=1.75$, $\mathrm{SD}=.50$ ). $\mathrm{Na}$ afloop van PPG maken de ouders wier hulpvragen zijn beantwoord, zich nog steeds minder bezorgd over de ontwikkeling van hun andere kinderen (t(11) $=-1.86 ; \mathrm{p}<.05$, een-zijdig), voelen zij zich in sociaal opzicht minder geïsoleerd $(t(18)=-1.76 ; p<.05$, een-zijdig $)$ en geestelijk en lichamelijk beter $(t(18)=-1.71$; p<.05, een-zijdig).

\section{Subgroep omgangsproblemen binnen het gezin}

De ouders wier hulpvragen betreffende de omgang van het gehandicapte kind met de overige gezinsleden helemaal of grotendeels zijn beantwoord, gebruiken na afloop van de hulpverlening andere copingstijlen dan de ouders wier hulpvragen op dit gebied niet of nauwelijks zijn beantwoord (multivariate $F(5,9)=4.64, p<.05$ ). Zij gebruiken met name de copingstijl "vermijding" minder vaak (univariaat: $p<.01$ ). De ouders wier hulpvragen zijn beantwoord, zijn deze copingstijl gedurende de hulpverlening minder vaak gaan hanteren terwijl de ouders wier hulpvragen niet of nauwe- 
lijks zijn beantwoord, de copingstijl "vermijding" vaker zijn gaan gebruiken $(\mathrm{F}(2,12)=10.46 ; \mathrm{p}<.01)$.

\subsubsection{Algemene satisfactie}

De ouders zijn tenslotte drie vragen gesteld die samen een beeld geven van hun algemene satisfactie met Praktisch Pedagogische Gezinsbegeleiding (zie 6.1.2):

(1) In totaal geven 37 ouders aan in het algemeen "zeer tevreden", 7 ouders "redelijk tevreden", 1 ouderpaar "nauwelijks tevreden" en 1 ouderpaar "niet tevreden" te zijn over de hulpverlening. De overige 2 ouders zijn het antwoord op deze vraag schuldig gebleven.

(2) Voorts zouden 41 ouders andere ouders aanraden zich bij PPG aan te melden als ziji vragen of problemen hebben over de opvoeding van of de omgang met het gehandicapte kind. De overige 7 ouders zeggen dit niet te weten. De 41 eerstgenoemde ouders zijn in het algemeen meer tevreden over PPG dan de overige ouders ( $(\mathrm{t}(44)=3.04 \%, \mathrm{p}<.01$, een-zijdig).

(3) Tenslotte zeggen 19 ouders de opvoeding van het verstandelijk gehandicapte kind "helemaal", 26 ouders de opvoeding "grotendeels", 2 ouders de opvoeding "nauwelijks" en 1 ouderpaar de opvoeding van het gehandicapte kind "helemaal niet" zelf weer aan te kunnen mu de hulpverlening is afgesloten. De antwoorden op deze vraag naar het uiteindelijke doel van PPG hangen niet samen met de algemene tevredenheid met de hulp $(r=.08 ; n . s$.$) en slechts in geringe mate met$ de antwoorden op de vraag of men andere ouders zou aanraden zich voor PPG aan te melden. ( $(\mathrm{t}(46)=1.37 ; \mathrm{p}<.10$, een-zijdig).

Gezien de verbanden tussen de drie indices van de algemene satisfactie met de hulpverlening, zijn alleen de antwoorden op vraag 1 (algemene tevredenheid) en vraag 3 (doel van PPG) gerelateerd aan de duur en frequentie van Praktisch Pedagogische Gezinsbegeleiding, de stress van de ouders en de determinanten daarvan na afloop van de hulpverlening en de veranderingen daarin tussen de vooren de nameting. Tabel 9.5 geeft alleen de significante correlaties weer. Hieruit blijkt onder andere dat ouders de opvoeding van hun gehandicapte kind beter menen aan te kunnen naarmate zij na afloop van PPG minder stress ervaren en naarmate de determinanten daarvan minder ernstig zijn.

De algemene satisfactie met PPG is voorts gedeeltelijk afhankelijk van de aard van de hulpvragen. Alle subgroepen zijn in het algemeen even tevreden over PPG. De ouders in de subgroepen "omgangsproblemen binnen het gezin" en "sociale vaardigheden" menen echter de opvoeding van het gehandicapte kind minder goed weer aan te kunnen dan de ouders in de overige subgroepen $(t(46)=-2.90 ; p<.01$, een-zijdig respectievelijk $\mathbf{t}(46)=-1.84 ; p<.05$, een-zijdig).

In eén subgroep hangt de algemene satisfactie met PPG tevens samen met de mate waarin de hulpvragen zijn beantwoord: de ouders in de subgroep "gedragsproblemen" wier hulpvragen geheel of grotendeels zijn beantwoord, zijn meer tevreden over PPG $(t(24)=2.74 ; p<.01$, een-zijdig) en hebben meer het idee de opvoeding van het gehandicapte kind zelf weer aan te kunnen $(t(25)=1.79 ; p<.05$, een-zijdig) dan de 
ouders wier vragen over de gedragsproblematiek van het kind niet of nauwelijks zijn beantwoord.

\section{Tabel 9.5}

Pearson correlaties van de algemene tevredenheid en het doel van PPG met duur, frequentie, stress na afloop en stressveranderingen $(n=48)$

Algemene Doel PPG
tevredenheid

\section{Dour PPG}

Frequentie PPG

Stress en determinanten na PPG:

1. Sociale redzaamheid k.v.h.

2. Sociale vaardigheden en zelfredzaamheid kw.h.

3. Zelfwaardering ouders

4. Relatie k.v.h. met broer(s) en/of zus(sen)

5. Gezinswerstoring

6. Praktische druk

7. Problemen met betrekking tot de partner

8. Psychosomatisch onwelbevinden

9. Copingstijl "depressief reactiepatroon"

10. Copingstijl "expressie van emoties"

11. Sociale isolatie

Verandleringen in:

1. Lichamelijke gezondheid k.v.h.

2. Zorgen over ontwikkeling van de andere kinderen

3. Copingstijl "depressief reactiepatroor"

4. Copingstijl "expressie van emoties"

$\begin{array}{cc}.10 & -.12 \\ .20^{*} & .03 \\ & \\ -.10 & .29^{* *} \\ -.15 & .20^{*} \\ .13 & .36^{* * *} \\ .16 & .28^{* * *} \\ -.13 & -.33^{* * *} \\ -.09 & -.22^{*} \\ -.12 & -.41^{* * *} \\ -.25^{* *} & -.36^{* * *} \\ -.25^{* *} & -.29^{* * *} \\ .20^{*} & .20^{*} \\ -.26^{* *} & -.33^{* * *} \\ & -.03 \\ .25^{* * *} & -.40^{* * * *} \\ -.18 & -.10 \\ -.19^{*} & .19^{*}\end{array}$

Noot. K.v.h.= kind met een verstandelijke handicap.

${ }^{*} p<.10$, een-zijdig. ${ }^{* *} p<.05$, een-zijdig. ${ }^{* * *} p<.01$, een-zijdig.

\subsubsection{Samenvatting: Oordelen over PPG}

De ouders die bij deze evaluatie zijn betrokken, zijn in het algemeen tevreden over de hulp die zij van de afdelingen Praktisch Pedagogische Gezinsbegeleiding hebben gekregen. De meeste ouders menen tevens de opvoeding van het gehandicapte kind zelf weer aan te kunnen nu de hulpverlening is afgesloten. Dit geldt met name voor die ouders die na afloop van de hulp minder stress ervaren en bij wie de determinanten ervan minder emstig zijn. De ouders zijn bovendien uitermate positief over de vormgeving van $\mathrm{PPG}$.

In totaal is ruim de helft van alle hulpvragen met behulp van Praktisch Pedagogische Gezinsbegeleiding beantwoord. In ongeveer twee derde van de gezinnen zijn de hulpvragen betreffende de gedragsproblemen van het gehandicapte kind beantwoord. In de subgroep "gedragsproblemen" is tevens enige ondersteuning gevonden voor de veronderstelling dat ouders beter geholpen kunnen worden naarmate zij voorafgaand aan de hulp minder stress ervaren: vooral ouders die zich relatief weinig zorgen maakten over de ontwikkeling van de andere kinderen en ouders die zich in psychosomatisch opzicht relatief goed voelden, zijn met PPG goed geholpen. Bovendien 
zijn binnen deze subgroep vooral de ouders wier zelfwaardering is toegenomen, wier gevoelens van sociale isolatie zijn afgenomen en die minder vaak een depressieve copingstijl zijn gaan hanteren, van oordeel dat hun hulpvragen zijn beantwoord.

Praktisch Pedagogische Gezinsbegeleiding is in ongeveer de helft van de gezininen een adequate vorm van hulp gebleken bij vragen betreffende de stimulering van de ontwikkeling van het gehandicapte kind. In de subgroep "ontwikkelingsstimulering" is eveneens gebleken dat ouders die zich voorafgaand aan de hulpverlening minder bezorgd maakten over de ontwikkeling van de andere kinderen, zich in psychosomatisch opzicht beter en in sociaal opzicht minder geïsoleerd voelden, meer profijt van de hulpverlening hebben.

Met een langere hulpverleningsperiode dan bij de andere opvoedingsvragen nodig was, zijn ook omgangsproblemen tussen het gehandicapte kind en de overige gezinsleden voor een groot gedeelte door PPG hanteerbaar gemaakt. De ouders wier hulpvragen op dit terrein liggen, zijn even tevreden over Praktisch Pedagogische Gezinsbegeleiding als ouders met andere hulpvragen, maar hebben, of hun hulpvragen nu zijn beantwoord of niet, minder het gevoel de opvoeding van hun gehandicapte kind zelf weer aan te kunnen. In de subgroep "omgangsproblemen binnen het gezin" hebben vooral ouders die tijdens de hulpverlening de copingstijl "vermijding" minder frequent zijn gaan gebruiken, baat bij de hulp gehad.

Praktisch Pedagogische Gezinsbegeleiding heeft tenslotte vragen van ouders op het gebied van de ontwikkeling van de sociale vaardigheden die het gehandicapte kind in staat moeten stellen contacten buiten het gezin te onderhouden, nauwelijks kunnen beantwoorden. Toch zijn ouders met hulpvragen op dit gebied even tevreden over de hulpverlening als ouders met andere hulpvragen. Na de afsluiting van PPG hebben zij echter minder dan andere ouders het gevoel de opvoeding van het gehandicapte kind zelf weer aan te kunnen.

\subsection{Praktische Thuishulp}

\subsection{Beschrijing van de PT-groep in de nameting}

Bij de analyses ten aanzien van de effecten van en oordelen over Praktische Thuishulp zijn de gegevens van 11 van de oorspronkelijke 25 PT-ouders betrokken (zie 6.2). Analyses op de variabelen uit de blokken $1 \mathrm{t} / \mathrm{m} 8$ in de voormeting lijken erop te duiden dat onder deze 11 verstandelijk gehandicapte kinderen toen minder meisjes en meer jongens waren $\left(\operatorname{chi}^{2}(1)=3.07 ; \mathrm{p}<.10\right)$ en meer jongste, meer enig en minder oudste kinderen $\left(\operatorname{chi}^{2}(3)=10.47 ; \mathrm{p}<, 05\right)$ dan onder de 14 gehandicapte kinderen wier ouders niet bij de analyses in de nameting zijn betrokken. Bovendien lijkt het aantal ouders dat steun ontvangt van de partner, onder de eerste 11 ouders groter te zijn dan onder de overige ouders $\left(\mathrm{chi}^{2}(1)=5.56 ; \mathrm{p}<.05\right)$. De nametingsscores van de PT-groep op de overige variabelen (zie de derde kolom in tabel 9.1 respectievelijk bijlage $E$, tabel 1 en 2) kunnen dan ook worden vergeleken met de voormetingsscores (zie tabel 8.1 respectievelijk bijlage $\mathrm{D}$, tabel 1 en 2). 
De verschillen die in de voormeting met de controlegroep bestonden, ten aanzien van de sociale klasse en het opleidingsniveau van de ouders en de relatie tussen het gehandicapte kind en zijn of haar broer(s) en/of zus(sen) (zie 8.3.1 en 8.3.2), zijn in

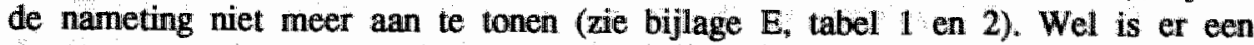
verschil in coping (multivariate $F(5,51)=2.37 ; \mathrm{p}<.05$ ). De ouders in de PT-groep gebruiken de copingstijl "sociale steun zoeken" vaker dan de ouders in de controlegroep (univariaat: $\mathrm{p}<.001$ ), omdat deze laatste ouders gedurende de hulpverleningsperiode minder vaak steun in hun omgeving zijn gaan zoeken en de PT-ouders juist vaker $(\mathrm{F}(2,53)=2.13 ; \mathrm{p}<.01)$.

\subsubsection{Effecten}

Naar aanleiding van de beschrijving van Praktische Thuishulp als hulpvorm (zie 5.2) en de resultaten van de toetsen op de stressmodellen (zie 7.4.2) zijn drie hypotheses opgesteld ten aanzien van de effecten van Praktische Thuishulp:

In gezinnen die Praktische Thuishulp hebben:

Hypothese 4-1: heeft een grotere reductie in de praktische druk van de ouders plaatsgehad;

Hypothese 4-2: heeft zich een grotere afname in de stresserende kenmerken van het verstandelijk gehandicapte kind voorgedaan, met name wat de gedragsproblematiek en de vaardigheden ten aanzien van sociaal gedrag en zelfredzaamheid betreft; en Hypothese 4-3: hebben de ouders meer zelfwaardering gekregen, dan in gezinnen die geen Praktische Thuishulp hebben.

De effecten van de hulp zijn alleen voor de totale PT-groep geanalyseerd en wel in dezelfde drie rondes als de effecten van PPG (zie 9.2.2.1 en 6.3.2). De geringe omvang van de PT-groep maakt analyses bedoeld om na te gaan in hoeverre de PT-subgroepen in gelijke mate van de hulp hebben geprofiteerd, onmogelijk. Bovendien maakt de geringe omvang enig voorbehoud met de in tabel 9.6 gepresenteerde resultaten van de eerste twee analyse-rondes noodzakelijk.

Tabel 9.6

Analyse-resultaten ten aanzien van de effecten van Praktische Thuishulp

Resultaten

(A) PT-groep: $\quad$ (B) PT-controlegroep:

Verschillen voor- nameting Verschillen met controle

Hypotheses voor initiéle vergchillen

4-1. Praktische druk

(A) n.s.

(B) n.s.

4-2. Stresserende kenmerken verstandelijk gehandicapt kind

$\begin{array}{lll} & \text { (A) n.s. } & \text { (B) n.s. } \\ \text { 4-3. Zelfwaardering } & \text { (A) } t(10)=2.14 ; p<.05, & \text { (B) } F(2,54)=5.94 ; p<.05 \\ & \text { een-zijdig } & \end{array}$


Uit tabel 9.6 lijkt alleen de zelfwaardering van de ouders in de PT-groep meer te zijn toegenomen dan de zelfwaardering van de ouders in de controlegroep. De twee overige hypotheses lijken te moeten worden verworpen. De gegevens in de derde kolom van tabel 9.1 ondersteunen de conclusies uit de eerste twee analyse-rondes gedeeltelijk. Na een jaar is de praktische druk in de PT-groep groter dan in de controlegroep (hypothese 4-1), zoals ook in de voormeting het geval was. Een ANCOVA (zie 6.3.2) maakt duidelijk dat deze grotere praktische druk evenmin als in de woormeting gemedieerd wordt door de determinanten ervan (zie tabel 7.5). Voorts is er geen verschil meer tussen beide groepen in de vaardigheden ten aanzien van sociaal gedrag en zelfredzaamheid van de verstandelijk gehandicapte kinderen (hypothese 4-2). Hoewel dit voorafgaand aan de Praktische Thuishulp wel het geval was (vergelijk tabel 8.1), kan gezien de resultaten in tabel 9.6 niet geconcludeerd worden dlat de afname van dit stresserende kenmerk aan de thuishulp moet worden toegeschreven.

Tenslotte blijkt uit tabel 9.1 dat de zelfwaardering van de ouders in de PT-groep na een jaar Praktische Thuishulp groter is dan de zelfwaardering van de ouders in de controlegroep (hypothese 4-3). Voorafgaand aan de hulpverlening was er geen verschill in dit opzicht. De grotere zelfwaardering in de PT-groep blijkt los te staan van de gedragsproblematiek van de gehandicapte kinderen, de belangrijkste correlaat van de zelfwaardering van ouders in het algemeen (zie bijlage $\mathrm{C}$, tabel 1).

Op basis van deze gegevens kan worden geconcludeerd dat Praktische Thuishulp geen invloed heeft op de praktische druk van de ouders en de stresserende kenmerken van de gehandicapte kinderen, maar wel de zelfwaardering van de ouders doet toenemen.

\section{3 .3 Oordelen}

Na een jaar Praktische Thuishulp is de ouders een oordeel gevraagd over de vormgeving van de hulp, de mate waarin de hulp aan hun verwachtingen heeft voldaan en de algemene satisfactie met de hulp (zie 6.1.2). Gezien de geringe ornvang van de PT-groep moeten de gegevens voorzichtig worden geïnterpreteerd en zijn analyses met betrekking tot de vraag welke ouders meer en welke ouders minder positief oordelen over de hulpverlening, als te weinig zinvol achterwege gelaten. De data worden in 9.3.3.1 t/m 9.3.3.3 weergegeven.

\subsubsection{Vormgeving}

\section{Frequentie}

Van de 11 ouders hebben 2 ouders gemiddeld eens per twee weken hulp gehad, 2 ouders gemiddeld eens per maand, 4 ouders gemiddeld eens per twee tot drie maanden en 3 ouders minder vaak dan eens per drie maanden. Vergelijkingen met de frequentie die de ouders bij hun aanmelding als wenselijk opgaven (zie 8.3.4), laten zien dat:

(a) 1 ouderpaar vaker van de hulp gebruik gemaakt heeft (eens per twee weken) dan

het bij de aanmelding wenste (eens per maand); 
(b) 1 ouderpaar even frequent van Praktische Thuishulp gebruik gemaakt heeft als het wenste (eens per twee tot drie maanden); en

(c) de overige 9 ouders minder frequent van Praktische Thuishulp gebruik gemaakt hebben dan zij bij hun aanmelding wensten.

Vier aspecten van de vormgeving

De ouders zijn gemiddeld genomen redelijk tot zeer tevreden over de wijze waarop de vrijwilliger omgaat met het gehandicapte kind en de overige gezinsleden (zie tabel 9.7). Een aantal ouders mist echter het contact met de contactpersoon of (wijk-)coördinator van de Praktische Thuishulpcentrale omdat er soms ,problemen met de vrijwilliger zijn, bijvoorbeeld omdat deze niet altijd op de gewenste tijden beschikbaar is, geen eigen vervoer heeft of niet goed geïnformeerd lijkt te zijn over de handicap van het kind. Het totale oordeel over de hulp is evenwel positief.

Tabel 9.7

Aantal ouders die zeer tot niet tevreden zijn over de vormgeving van Praktische Thuishulp $(n=11)$

Tevredenheid

\section{Vormgevingsaspecten}

zeer redelijk/nauwelijks/niet

1. Contact ouder - vrijwilliger

2. Contact vrijwilliger - k.v.h.

3. Relatie vrijwilliger - overige gezinsleden

4. Contact ouder - contactpersoon

5. Totaal oordeel

$\begin{array}{ll}6 & 5 \\ 8 & 2 \\ 8 & 1 \\ 4 & 4 \\ 7 & 3\end{array}$

Noot. K.v.h.= kind met een verstandelijke handicap.

\subsubsection{Inhoud}

De verwachtingen die de ouders bij hun aanmelding van Praktische Thuishulp hadden (zie 8.3.3), zijn een jaar later in dezelfde bewoordingen aan hen woorgelegd met de vraag in welke mate de hulpverlening hieraan heeft kunnen voldoen. De gegevens staan in tabel 9.8 .

Tabel 9.8

Aantal ouders aan wier verwachting Praktische Thuishulp helemaal tot niet heeft voldaan $(n=11)$

Aan de verwachting voldaan

helemaalgrotendeels nauwellijks/niet

1. Oppas $(n=5)$

2. Bezigheidsbegeleiding ( $n=5)$

3. Hulp bij de verzorging $(n=1)$

4. Vervoersproblemen $(n=1)$

5. Taakwerlichting $(n=3)$

$\begin{array}{ll}2 & 3 \\ 5 & - \\ 1 & - \\ -1 & 2\end{array}$


Uit tabel 9.8 kan gezien de geringe omvang van de subgroepen en gezien het feit dat niet alle ouders deze vraag hebben beantwoord, niet mér geconcludeerd worden dan dat ouders die bezigheidsbegeleiding of hulp bij de verzorging van het kind aanvroegen, meer tevreden over de inhoud van de hulp lijken te zijn dan ouders die Praktische Thuishulp om andere redenen aanvroegen.

\subsubsection{Algemene satisfactie}

Gevraagd naar de mate waarin men in het algemeen tevreden is over Praktische Thuishulp, geven 5 ouders aan "zeer tevreden", 4 ouders "redelijk tevreden", 1 ouderpaar "nauwelijks tevreden" en 1 ouderpaar "niet tevreden" te zijn. Van de 10 ouders die de vraag hebben beantwoord of zij andere ouders met praktische problemen zouden aanraden zich bij de Praktische Thuishulpcentrales aan te melden, geven 9 ouders aan dat zij dat zouden doen en zegt 1 ouderpaar dit niet te weten.

\subsubsection{Samenvatting: Effecten van en oordelen over PT}

Van de 25 ouders die Praktische Thuishulp aanvroegen, maken slechts 11 ouders na een jaar (nog) gebruik van deze hulp. Deze ouders ervaren nog steeds meer praktische druk dan ouders die geen Praktische Thuishulp aanvroegen. Zij hebben daarentegen beduidend meer zelfwaardering gekregen. Ondanks het feit dat de ouders minder frequent een beroep op de vrijwilliger van de Praktische Thuishulpcentrales hebben gedaan dan zij bij hun aanmelding wensten, zijn hun oordelen over de hulp redelijk tot zeer positief. Enkele ouders zouden alleen meer contact willen hebben met de contactpersoon of (wijk-)coördinator van de centrale om problemen in hun relatie met de vrijwilliger te kunnen bespreken. Over de mate waarin de hulp heeft voldaan aan de verschillende verwachtingen van de ouders, zijn gezien de geringe omvang van de PT-groep nauwelijks uitspraken te doen.

\subsection{Weekendopvang}

\subsection{Beschrijving van de WO-groep in de nameting}

Bij de analyses ten aanzien van de effecten van en oordelen over Weekendopvang zijn de gegevens van 42 van de oorspronkelijke 64 ouders in de WO-groep betrokken (zie 6.2). Vergelijkingen op de voormeting tussen deze ouders en de $22 \mathrm{WO}-$ ouders die niet bij de nameting zijn betrokken, laten zien dat er toen in geen enkel opzicht verschillen waren. Dit betekent onder meer dat de scores op de nameting (zie de vierde kolom in tabel 9.1 respectievelijk bijlage $E$, tabel 1 en 2) te vergelijken zijn met die op de voormeting (zie tabel 8.1 en bijlage D, tabel 1 en 2) om een indruk te krijgen van de effecten van Weekendopvang.

Het verschil dat voorafgaand aan de hulpverlening met de controlegroep bestond ten aanzien van de plaats van het gehandicapte kind in de kinderrij (zie 8.4.1) is in de nameting niet meer aangetroffen (zie bijlage $\mathrm{E}$, tabel 2). Ook de relatie tussen het gehandicapte kind en zijn of haar broer(s) en/of zus(sen) is na een jaar Weekendopvang niet meer slechter dan in de controlegroep (zie bijlage E, tabel 1). Dit komt 
niet doordat deze relaties in de WO-groep zouden zijn verbeterd (gepaarde Student's t-toets: $t(37)=.80$; n.s.), maar doordat zij in de controlegroep meer zijn verslechterd dan in de WO-groep $(F(2,75)=2.89 ; p<.10)$.

\subsubsection{Effecten}

Naar aanleiding van de beschrijving van Weekendopvang als hulpvorm (zie 5.3) en de resultaten van de toetsen op de stressmodellen (zie 7.4.2) zijn zes hypotheses opgesteld ten aanzien van de effecten van de opvang:

In gezinnen die Weekendopvang hebben:

Hypothese 6-1: heeft een grotere reductie in de concrete problemen van de ouders plaatsgehad;

Hypothese 6-2: heeft een grotere toename in het psychosomatisch welbevinden van de ouders plaatsgehad:

Hypothese 6-3: heeft zich een grotere afname in de stresserende kenmerken van het verstandelijk gehandicapte kind voorgedaan,

Hypothese 6-4: hebben de ouders meer zelfwaardering gekregen:

Hypothese 6-5: zijn de ouders minder vaak de copingstijl "depressief reactiepatroon" gaan gebruiken; en

Hypothese 6-6: heeft zich bij de ouders een grotere afname in de gevoelens van sociale isolatie voorgedaan.

dan in gezinnen die geen Weekendopvang hebben.

De effecten van Weekendopvang zijn eerst woor de totale WO-groep nagegaan (9.4.2.1) en vervolgens voor elk van de WO-subgroepen (9.4.2.2).

\subsubsection{Effecten voor de totale WO-groep}

De analyses ten aanzien van de effecten van Weekendopvang op de totale WOgroep zijn in dezelfde drie rondes uitgevoerd als die ten aanzien van de effecten van PPG (zie 6.3.2 en 9.2.2.1). De uitkomsten ervan zijn als volgt samen te vatten. Uit de eerste analyse-ronde blijkt dat er binnen de WO-groep geen verschillen zijn tussen de voor- en nameting met betrekking tot de variabelen uit de hypotheses 6-1 t/m 6-6. De resultaten uit de tweede analyse-ronde laten zien dat do WO-groep in de loop van het jaar tussen de voor- en de nameting in deze opzichten niet meer of minder is veranderd dan de controlegroep. Op grond hiervan moeten alle zes hypotheses verworpen worden.

De vergelijkingen tussen de WO-groep en de controlegroep op de scores in de nameting alleen, de derde analyse-ronde, maken cén voorzichtige uitzondering en wel ten aanzien van de in hypothese 6-1 genoemde concrete problemen van de ouders. Na een jaar Weekendopvang is er in dit opzicht namelijk nog slechts een gering verschil tussen beide groepen (multivariate $F(4,69)=2.01 ; p<.10$ ), dat bovendien alleen is toe te schrijven aan de grotere praktische druk in de WO-groep (zie de vierde kolom in tabel 9.1). Tevens blijkt dat deze grotere praktische druk geheel voor rekening komt van de determinanten van dit concrete probleem (zie tabel 7.5). Bij hun aanmelding voor Weekendopvang hadden de ouders mér concrete problemen en betroffen ze naast een grotere praktische druk ook een grotere gezinsver- 
storing en een grotere bezorgdheid over de ontwikkeling van de andere kinderen in het gezin (vergelijk tabel 8.1). Bovendien konden deze verschillen toen niet worden toegeschreven aan de determinanten van deze problemen.

Hoewel geconcludeerd moet worden dat Weekendopvang geen aantoonbare en eenduidige invloed heeft op de stress van de ouders, kan tevens worden vastgesteld dat de relaties tussen de ouders en de kinderen en tussen de kinderen onderling (zie 9.4.1) na een jaar Weekendopvang beter zijn dan toen de gezinnen zich voor deze hulp aanmeldden.

\subsubsection{Effecten per subgroep}

In de voormeting zijn zeven subgroepen onderscheiden op basis van de redenen die de ouders bij hun aanmelding voor Weekendopvang noemden (zie 8.4.3). In dezelfde drie analyse-rondes als bij de totale WO-groep zijn zes daarvan na een jaar met de overige WO-gezinnen vergeleken om na te gaan of deze subgroepen in gelijke mate van de hulp hebben geprofiteerd. De subgroep "vertrouwde opvang" $(\mathrm{n}=3$ ) is hiervoor te gering van omvang. Alle variabelen waarop de hypotheses 6-1 t/m 6-6 betrekking hebben, zijn bestudeerd. Andere verschillen uit de voormeting zijn eveneens in de analyses betrokken.

\section{Subgroep rust voor de ouders ( $n=15$ )}

Bij de ouders in de subgroep "rust voor de ouders" hebben geen veranderingen tussen de voor- en de nameting plaatsgehad. Deze subgroep heeft dan ook niet aantoonbaar meer of minder van de Weekendopvang geprofiteerd dan de resterende WO-ouders. Wel blijkt dat de subgroep na een jaar Weekendopvang niet meer te onderscheiden is van de resterende ouders. Dit in tegenstelling tot voorafgaand aan de hulpverlening, toen de ouders in deze subgroep meer stress bleken te ervaren dan de overige WO-ouders.

\section{Subgroep activiteiten $(n=10)$}

Het leeftijdsverschil dat bij de aanmelding bestond tussen de subgroep "activiteiten" en de overige WO-gezinnen, is in de nameting niet meer aantoonbaar, omdat de periode tussen de voor- en de nameting in de subgroep gemiddeld een half jaar langer was dan bij de overige gezinnen. Tussen de voor- en de nameting hebben zich in de subgroep "activiteiten" geen wijzigingen voorgedaan in de stress van de ouders of de determinanten daarvan. De subgroep heeft dan ook niet aantoonbaar meer profijt van de Weekendopvang gehad dan de overige gezinnen. Na een jaar Weekendopvang hebben de verstandelijk gehandicapte kinderen in de subgroep "activiteiten" evenals in de voormeting meer stresserende kenmerken dan de overige gehandicapte kinderen (multivariate $F(4,37)=3.02 ; p<.05)$ : zij hebben minder sociale vaardigheden en een geringere zelfredzaamheid (univariaat: $\mathrm{p}<.01$ ) en een slechtere lichamelijke gezondheid (univariaat: $p<.05$ ).

\section{Subgroep tijd voor de andere kinderen $(n=11)$}

Evenals in de voormeting zijn de verstandelijk gehandicapte kinderen in de subgroep "tijd voor de andere kinderen" jonger dan de overige gehandicapte kinderen in de 
WO-groep ( $M=10.6$ jaar respectievelijk $M=13.9$ jaar; $t(40)=-2.00, p<.05$, eenzijdig). In deze subgroep is tussen de voor- en de nameting alleen een lichte vertbetering in én van de concrete problemen van de ouders opgetreden: zij zijn zich minder bezorgd gaan maken over de onfwikkeling van de andere kinderen in het gezin $(t(9)=-2.39 ; p<.05$, een-zijdig). Hoewel uit de tweede analyse-ronde blijkt dat deze verbetering niet significant groter is dan bij de overige gezinnen, blijkt uit de derde analyse-ronde dat de ouders in de subgroep "tijd voor de andere kinderen" na een jaar Weekendopvang op geen enkel terrein mér concrete problemen ervaren dan de overige WO-gezinnen. Voorafgaand aan de hulpverlening was dat wel het geval. $\mathrm{Na}$ een jaar Weekendopvang hebben de verstandelijk gehandicapte kinderen in deze subgroep nog steeds meer stresserende kenmerken dan de kinderen in de overige WO-gezinnen (multivariate $F(4,37)=3.65 ; \mathrm{p}<.01$ ). Zij hebben meer gedragsproblemen (univariaat: $p<.05$ ), minder sociale vaardigheden en een geringere zelfredzaamheid (univariaat: $\mathrm{p}<.05$ ) en een slechtere lichamelijke gezondheid (univariaat: $p<.05$ ). In tegenstelling tot vór de Weekendopvang kunnen deze verschillen niet worden toegeschreven aan hun jongere leeftijd.

\section{Subgroep ontlasting van de extra zorg $(n=8)$}

Het enige verschil tussen de voor- en de nameting betreft het feit dat do ouders in de subgroep "ontlasting van de extra zorg" iets meer dan de overige WO-ouders het gevoel hebben gekregen er alleen voor te staan $(F(2,38)=3.79 ; \mathrm{p}<.10)$. Na een jaar Weekendopvang blijken de ouders in deze subgroep zich dan ook meer sociaal geilsoleerd te voelen dan de overige ouders $(t(39)=2.49 ; p<.01$, een-zijdig). In de voormeting bestond geen enkel verschil tussen deze subgroep en de overige WOgezinnen.

\section{Subgroep ontspanning voor het verstandelijk gehandicapte kind $(n=17)$}

De gezinnen in de subgroep "ontspanning voor het verstandelijk gehandicapte kind" zijn evenals in de voormeting ouder dan de overige WO-gezinnen (multivariate $F(4,29)=2.51 ; p<.10)$. Ook de plaats van het gehandicapte kind in de kinderrij wijkt in deze subgroep nog steeds af van die van het gehandicapte kind in de overige WO-gezinnen (chi² $(3)=19.54 ; \mathrm{p}<.001)$ : er zijn weinig jongste en veel middelste en enig kinderen in deze subgroep. Er hebben zich in deze subgroep geen veranderingen tussen de voor- en de nameting voorgedaan. Na een jaar Weekendopvang betreft het enige verschil met de overige WO-gezinnen evenalls in de voormeting de stresserende kenmerken van de gehandicapte kinderen (multivariate $F(4,37)=3.38 ; p<.05$ ): in de subgroep zijn zij meer sociaal redzaam (univariaat: $p<.05$ ) en hebben zij meer sociale vaardigheden en een grotere zelfredzaamheid (univariaat: $p<.001$ ). Deze verschillen zijn geheel uit het leeftijdsverschil tussen beide subgroepen te verklaren.

\section{Subgroep gewenning aan toekomstige uithuisplaatsing ( $n=7$ )}

In de subgroep "gewenning aan toekomstige uithuisplaatsing" zijn geen veranderingen tussen de voor- en de nameting opgetreden. $\mathrm{Na}$ afloop van de Weekendopvang zijn er evenmin als in de voormeting verschillen tussen deze subgroep en de overige WO-gezinnen. 


\subsubsection{Sameniatting: Effecten wan WO}

Weekendopvang heeft geen eenduidige invloed op de stress van de ouders of de determinanten daarvan. Alle hypotheses dienaangaande zijn verworpen. Wel zijn de gezinsrelaties na een jaar Weekendopvang beter dan zij voordien waren. Weekendopvang heeft bovendien nawwelijks differentiëlle effecten per subgroep. In de subgroep "rust voor de ouders" lijkt de belasting, die voorafgaand aan de hulpverlening groot was, enigszins te zijn afgenomen. In de subgroep "tijd voor de andere kinderen" lijken de ouders zich minder bezorgd te zijn gaan maken over de ontwikkeling van hun andere kinderen. De ouders in de subgroep "ontlasting van de extra zorg" lijken daarentegen meer het gevoel te hebben gekregen er alleen voor te staan. Van de gezinnen in de resterende subgroepen is niet aangetoond dat zij meer of minder van de Weekendopvang geprofiteerd hebben dan de overige WO-gezinnen.

\subsubsection{Oordelen}

De ouders is gevraagd naar hun oordelen over de vormgeving van de Weekendopvang, naar de mate waarin de opvang aan hun verwachtingen heeft voldaan en naar hun algemene satisfactie met de opvang (zie 6.1.2). De antwoorden worden in 9.4.3.1 t/m 9.4.3.3 gepresenteerd. Aangezien 1 deelnemer slechts eén keer van de opvang gebruik gemaakt heeft en deze ouders geen oordelen hebben gegeven, zijn de gegevens van 41 ouders bij de analyses betrokken.

\subsubsection{Vormgeving}

De ouders is gevraagd acht aspecten betreffende de wijze waarop de Weekendopvang wordt gerealiseerd, te beoordelen. Sommatie en middeling van hun antwoorden (tabel 9.9), resulterend in een totaal oordeel, laat zien dat ongeveer twee derde van de ouders zeer tevreden en ongeveer éen derde redelijk, nauwelijks of niet tevreden is over de vormgeving van Weekendopvang.

Tabel 9.9

Aantal ouders die zeer tot niet tevreden zijn over de vormgeving van Weekendopvang $(n=4 I)$

Tevredenheid

Vormgevingsaspecten

zeer nedelijk/nauwelijks/niet

1. Verzorging

2. Begeleiding

$37 \quad 4$

3. Contact ouders - leiding

4. Accommodatie

5. Activiteiteni

6. Planning

7. Groepssamenstelling

8. Frequentie

9. Totaal oordeel 
Om na te gaan welke ouders minder positief oordelen over de acht afzonderlijke vormgevingsaspecten, zijn de ouders die zeer tevreden zijn over het betreffende aspect, telkens vergeleken met de ouders die redelijk, nauwelijks of niet tevreden zijn over het betreffende aspect. Nagegaan is of de oordelen afhankelijk zijn van:

(a) de hulpvragen van de ouders (met chi²-toetsen);

(b) de stress van de ouders na afloop van de hulpverlening (met MANOVA's, Student's t-toetsen en chi ${ }^{2}$-toetsen op de variabelen uit de blokken $1 \mathrm{t} / \mathrm{m} \mathrm{8}$ ); en

(c) de veranderingen tussen de voor- en de nameting in de stress van de ouders. Uit de hiertoe uitgevoerde (M)ANCOVA's blijkt dit niet het geval te zijn.

Gezien de zeer positieve oordelen over de verzorging en begeleiding van het gehandicapte kind tijdens de Weekendopvang, zijn deze twee vormgevingsaspecten buiten beschouwing gebleven.

Contact tussen ouders en leiding: Ouders zijn minder tevreden over hun contact met de leiding naarmate zij ouder zijn (multivariate $F(4,30)=2.69$; $p<.05$ ) en maarmate hun gehandicapte kind lichamelijk minder gezond is (multivariate $F(4,36)=2.39$; $\mathrm{p}<.10$; univariaat: $\mathrm{p}<.01$ ). Deze ouders willen beter geïnformeerd worden over de wijze waarop hun kind het weekend doorbrengt, bijvoorbeeld door middel van een kort schriftelijk verslag.

Accommodatie: Ouders zijn minder tevreden over de accommodatie naarmate zij zelf, hun gehandicapte kind en de andere kind(eren) in het gezin ouder zijn (multivariate $\mathrm{F}(4,30)=3.16 ; \mathrm{p}<.05)$. De ouders in subgroep "ontspanning voor het verstandelijk gehandicapte kind", waarin de gezinnen, zoals gezegd (zie 9.4.2.2), ouder zijn dan in de andere subgroepen, hebben meer kritiek op de accommodatie dan de overige ouders (chiz $(1)=3.25 ; p<10$ ). De kritiek in Zuidoost-Brabant betreft het feit dat de vakantieboerderij vrij klein is. De kritiek in Noordoost- en Midden-Brabant heeft betrekking op het feit dat de kinderdagverblijven weinig mogelijkheden voor privacy bieden.

Activiteiten: Naarmate de gezinnen ouder zijn, de ouders minder tevreden zijn over de activiteiten die 's weekends ondemomen worden (multivariate $F(4,28)=2.68$; p<.05). Deze ouders willen beter geïnformeerd worden over de activiteiten en voor zover zij wel goed geïnformeerd zijn, menen zij dat te weinig activiteiten specifiek op oudere kinderen gericht zijn. Eén ouderpaar geeft aan dat de activiteiten "gewoner" zijn dan zij hadden verwacht.

Planning: De kritiek op de planning betreft enerzijds het feit dat het kind regelmatiger van de Weekendopvang gebruik zou moeten kunnen maken en anderzijds het feit dat de planning tijdiger bij de ouders bekend zou moeten zijn. Het zijn met name ouders van een lichamelijk zwak verstandelijk gehandicapt kind (multivariate $F(4,35)=2.66 ; p<.05$; univariaat: $p<.05$ ) en ouders uit een hogere sociale klasse respectievelijk met een hoger opleidingsniveau (multivariate $F(3,35)=3.45 ; p<.05$ ) die dit soort kritiek uiten. 
Groepssamenstelling: Ruim de helft van de ouders uit kritiek op de samenstelling van de groepen die gezamenlijk het weekend doorbrengen in de vakantieboerderij respectievelijk in éen van de kinderdagverblijven. De groepen worden heterogeen samengesteld (zie 5.3). Uit de opmerkingen van de ouders blijkt dat zij met name moeite hebben met de verschillen in leeftijd, verstandelijk niveau van functioneren en gedrag. Aangezien geen van de analyses significante resultaten laat zien, kan worden vastgesteld dat de kritiek op de groepssamenstelling vrij algemeen is.

Frequentie: Over de frequentie waarmee het gehandicapte kind in het jaar tussen de voor- en de nameting een weekend van de opvangmogelijkheid gebruik heeft gemaakt, is men minder tevreden dan over de meeste andere vormgevingsaspecten (zie tabel 9.9). Deze frequentie ligt volgens opgave van de ouders tussen én en negen weekends op jaarbasis met een gemiddelde van vier weekends per jaar. Wanneer de gerealiseerde frequentie vergeleken wordt met de frequentie die de ouders bij hun aanmelding als wenselijk opgaven (zie 8.4.4), dan blijkt dat:

(a) 4 kinderen frequenter thebben deelgenomen dan hun ouders bij de aanvang wensten. $\mathrm{Z}_{\mathrm{ij}}$ waren aangemeld voor een frequentie van eens per drie maanden en hebben uiteindelijk tussen vijf en acht weekends in de opvang doorgebracht;

(b) 3 kinderen even frequent van de Weekendopvang gebruik hebben gemaakt als hun ouders bij de aanvang wensten, namelijk 2 kinderen eens per drie maanden en 1 kind eens per zes tot acht weken; en

(c) de overige 31 kinderen minder frequent van de Weekendopvang gebruik hebben gemaakt dan hun ouders bij de aanmelding wensten (van de resterende kinderen ontbreken de gegevens). Onder deze 31 kinderen bevinden zich alle 16 kinderen wier ouders een frequentie van éen weekend per maand wenselijk vonden, 10 van de 11 kinderen wier ouders eens per zes tot acht weken een weekend opvang wensten en 5 van de 11 kinderen wier ouders eens per drie maanden van de Weekendopvang gebruik wilden maken.

Uit tabel 9.9 blijkt dat 24 van de 31 ouders die minder frequent van de Weekendopvang gebruik hebben gemaakt dan zij bij hun aanmelding hoopten, daar ontevreden over zijn. Deze ouders ervaren op drie punten meer stress dan de 16 ouders die wel tevreden zijn over de frequentie, ook al is deze voor een aantal van hen lager dan zij bij hun aanmelding wensten. De eerstgenoemde 24 verstandelijk gehandicapte kinderen hebben meer gedragsproblemen (multivariate $F(4,35)=2.27 ; p<.10$; univariaat: $p<.01$ ), hun ouders ervaren meer gezinsverstoring (multivariate $F(4,27)=3.72$; $p<.05$; univariaat: $p<.01$ ) en voelen zich lichamelijk en geestelijk slechter $(t(38)=2.32 ; p<.01$, een-zijdig). Het zijn met name de ouders in de subgroep "rust voor de ouders" die niet tevreden zijn over de frequentie waarmee hun gehandicapte kind in de periode tussen de voor-en de nameting van de Weekendopvang gebruik heeft kunnen maken $\left(\mathrm{chi}^{2}(1)=3.10 ; \mathrm{p}<10\right)$.

Bij de beschrijving van de projecten Weekendopvang (zie 5.3) is opgemerkt dat, aangezien de vraag naar Weekendopvang het aanbod overstijgt, de hulpverleners het aanbod over de gezinnen verdelen op basis van de relatieve ernst van de belasting in de betrokken gezinnen. Uit correlaties tussen de gerealiseerde frequentie van 
deelname en de stress en de determinanten daarvan voorafgaand aan de hulpverlening, blijkt dat gezinnen vaker van de Weekendopvang gebruik hebben mogen maken naarmate het gehandicapte kind minder sociaal redzaam was $(r=-.33 ; p<.05$, eenzijdig), zijn of haar relatie met de andere kinderen in het gezin siechter was ( $r=-29$; $p<.05$, een-zijdig), de ouders minder zelfwaardering hadden ( $r=-24, p<10$, eenzijdig), meer problemen met hun partner ervoeren ( $r=.22 ; p<10$, een-zijdig), zich in psychosomatisch opzicht slechter voelden $(r=.28 ; p<.05$, een-zijdig) en meer sociaal geïsoleerd waren ( $r=.22 ; p<.10$, een-zijdig). Afgezien van het feit dat de hulpverleners meer aandacht aan de gedragsproblematiek van het gehandicapte kind zouden kunnen besteden, blijkt de verdeling van de weekends inderdaad op basis van de relatieve belasting van de gezinnen te hebben plaatsgevonden.

Tenslotte blijkt noch de door de ouders gerapporteerde frequentie van deelname noch hun oordeel daarover van invloed te zijn geweest op de effecten van Weekendopvang (hypotheses $61 \mathrm{t} / \mathrm{m}$ 66). Uit (M)ANCOVA's waarbij de gerealiseerde frequentie respectievelijk het oordeel van de ouders daarover als factor is ingevoerd, blijkt dat ouders die minder vaak van de Weekendopvang gebruik hebben gemaakt respectievelijk ouders die minder tevreden zijn over de frequentie van deelname, in de stress die zij ervaren en de determinanten daarvan evenveel van de opvang hebben geprofiteerd als ouders die frequenter van de opvang gebruik maakten respectievelijk als ouders die tevreden zijn over de frequentie van deelname.

\subsubsection{Inhoud}

In de voormeting is de ouders gevraagd welke verwachtingen zij van de Weekendopvang hadden. In de nameting zijn de verwachtingen in dezelfde bewoordingen aan hen voorgelegd met de vraag in hoeverre de opvang hieraan heeft voldaan. Uit de antwoorden op deze vraag (zie tabel 9.10) blijkt dat Weekendopvang aan alle verwachtingen voldoet.

Tabel 9.10

Aantal ouders aan wier verwachting de Weekendopvang helemaal tot niet heeft voldaan $(n=41)$

Aan de verwachting voldaan

Subgroepen

helemaal/grotendeels

nawwelijks/niet

1. Rust voor de ouders $(n=15)$

2. Activiteiten $(n=10)$

3. Tijd voor die andere kinderen $(n=11)$

4. Ontlasting van de extra zorg ( $n=8$ )

5. Ontspanning voor het verstandelijk. gehandicapte kind $(n=17)$

6. Gewenning an toekomstige uithuisplaatsing $(n=7)$

7. Vertrouwde opvang ( $n=3)$

15

10

11

7

14

5

2

-
-
-
1
2
1
1


De ouders is daamaast gevraagd of de weekends waarin het gehandicapte kind van de Weekendopvang gebruik maakt, anders zijn dan de weekends waarin het kind thuis is. De 40 ouders die deze vraag beantwoord hebben, reageerden als volgt:

(1) Van hen geven 5 ouders aan dat deze weekends en in de activiteiten die het gezin onderneemt en in de sfeer thuis, niet anders zijn dan andere weekends.

(2) Voorts geven 24 ouders aan dat zij in deze weekends activiteiten ondememen die met het gehandicapte kind erbij moeilijk te realiseren zijn. Onder deze ouders bevinden zich veel ouders uit de subgroepen "tijd voor de andere kinderen" $\left(\operatorname{ch}^{2}(1)=5.20 ; \mathrm{p}<, 05\right)$ en "activiteiten" $\left(\operatorname{chi}^{2}(1)=2.80 ; \mathrm{p}<.10\right)$. De betreffende 24 verstandelijk gehandicapte kinderen hebben meer gedragsproblemen, zijn minder sociaal redzaam, hebben minder vaardigheden ten aanzien van sociaal gedrag en zelfredzaamheid en een slechtere lichamelijke gezondheid dan de kinderen wier ouders niet aangeven tijdens de "vrije" weekends speciale activiteiten te ondememen (multivariate $F(4,37)=2.89$; $p<.05$; univariaat: $p<.05$ bij alle stresserende kenmerken).

(3) Tenslotte geven 24 ouders aan deze weekends rustiger, gemakkelijker en meer ontspannen te vinden dan de andere weekends. Overigens ondememen 13 van deze 24 ouders ook speciale activiteiten in deze weekends. De 24 gehandicapte kinderen hebben meer gedragsproblemen dan de overige kinderen (multivariate $F(4,37)=3.43$; $p<.05$; univariaat: $p<.05$ ). Hun ouders maken gemiddeld even frequent van de Weekendopvang gebruik als de resterende ouders, maar leveren vaker kritiek op de te lage frequentie van deelname $(t(38)=-1.70 ; p<.05$, eenzijdig).

\subsubsection{Algemene satisfactie}

Alle ouders zouden andere ouders aanraden zich bij de projecten Weekendopvang aan te melden als zij behoefte zouden hebben aan opvang van het gehandicapte kind gedurende de weekends. Op de vraag hoe tevreden men in het algemeen is over de Weekendopvang, antwoorden 29 ouders "zeer tevreden" en 12 ouders "redelijk tevreden" te zijn.

De algemene tevredenheid met de Weekendopvang hangt gedeeltelijk samen met de redenen die de ouders hadden om hun kind voor de opvang aan te melden. De ouders in de subgroepen "rust voor de ouders" en "tijd voor de andere kinderen" zijn meer tevreden $\left(\mathrm{chi}^{2}(\mathbb{1})=2.90 ; \mathrm{p}<.10\right.$ respectievelijk $\left.\mathrm{chi}^{2}(1)=2.96 ; \mathrm{p}<.10\right)$ en de ouders in de subgroep "ontspanning voor het verstandelijk gehandicapte kind" zijn minder tevreden $\left(\right.$ chi $\left.^{2}(1)=2.66 ; \mathrm{p}<10\right)$ dan de overige ouders.

De algemene tevredenheid over de Weekendopvang hangt niet samen met de frequentie waarmee het gehandicapte kind van de Weekendopvang gebruik heeft kunnen maken noch met de tevredenheid van de ouders hilerover, maar wel met de oordelen over de overige vormgevingsaspecten. Uit Student's t-toetsen op deze zeven aspecten en uit de toets op het totaal oordeel over de vormgeving van Weekendopvang blijkt dat men minder tevreden is over de opvang naarmate men meer kritiek op de vormgeving heeft $(t(38)=-5.11 ; p<.001$, een-zijdig). 
Voorts zijn de ouders minder tevreden over de Weekendopvang naarmate: (a) het verstandelijk gehandicapte kind lichamelijk minder gezond is (multivariate $\mathrm{F}(4,36)=2.61 ; \mathrm{p}<.05$; univariaat: $\mathrm{p}<.01$ ); (b) de sociale klasse waartoe het gezin behoort, hoger is respectievelijk de ouders een hogere opleiding hebben afgerond (multivariate $\mathrm{F}(3,36)=2.39 ; \mathrm{p}<10$ ); en (c) de gezinnen ouder zijn (multivariate $F(4,28)=3.30 ; p<.05)$. Andere rellaties met de stress van de ouders en de determinanten daarvan of met veranderingen daarin gedurende de hulpverleningsperiode zijn niet aangetroffen.

\subsubsection{Samenvatting: Oordelen over WO}

De oordelen van de ouders over de Weekendopvang zijn in het algemeen zo positief, dat alle ouders andere gezinnen zouden aanraden zich bij de drie onderzochte projecten aan te melden wanneer zij behoefte zouden hebben aan Weekendopvang voor het gehandicapte kind. De ouders zijn tevreden over de vormgeving van de projecten, met uitzondering van de heterogene groepssamenstelling en de te lage frequentie van deelname. De ouders hebben hun kind gemiddeld vier weekends naar de opvang mogen brengen, terwijl drie kwart van hen bij hun aanmelding een hogere frequentie wenste. Hoewel men gezinnen die zwaarder belast zijn, vaker van de opvang gebruik heeft laten maken dan gezinnen die zich minder belast voelen, zouden vooral ouders die veel stress ervaren als gevolg van de gedragsproblemen van het gehandicapte kind, vaker van de Weekendopvang gebruik willen maken.

Weekendopvang heeft grotendeels voldaan aan de verwachtingen van de ouders die deze hulp aanvroegen ter ondersteuning van hen zelf en de andere kinderen in het gezin. Deze ouders, wier gehandicapte kind veel stresserende kenmerken heeft, genieten van de rust in de "vrije" weekends en gebruiken deze om activiteiten te ondememen waar zij anders nauwelijks aan toe komen. De ouders die Weekendopvang vooral ter ontspanning van hun gehandicapte kind hebben aangevraagd, zijn minder tevreden over de opvang. Naar hun oordeel brengt het kind de weekends veelal door met kinderen die te jong zijn, zijn de activiteiten tijdens de weekends nauwelijks op oudere kinderen afgestemd en is er voor deze oudere kinderen te weinig ruimte en privacy in de accommodaties waarin de respectievelijke projecten hun opvang realiseren. Ook ouders van lichamelijk zwakke kinderen hebben kritiek op de opvang, met name op de planning en op de te summiere informatie vanuit de leiding over de wijze waarop hun kind het weekend heeft doorgebracht.

\subsection{Besluit: Effecten van en oordelen over thuiszorg}

De effecten van Praktisch Pedagogische Gezinsbegeleiding, Praktische Thuishulp en Weekendopvang op de stress van de ouders en de determinanten daarvan zijn niet zo groot als werd verwacht op basis van de beschrijvingen van deze hulpvormen en de resultaten van de toetsen op de stressmodellen. PPG beïnvloedt alleen de sociale redzaamheid en de vaardigheden ten aanzien van sociaal gedrag en zelfredzaamheid van de verstandelijk gehandicapte kinderen in positieve zin, Praktische Thuishulp heeft alleen een gunstige invloed op de zelfwaardering van de ouders en de hypotheses ten aanzien van de effecten van Weekendopvang zijn alle verworpen. Er hebben 
weliswaar meer verbeteringen plaatsgehad, met name in de PPG-groep en in mindere mate ook in de WO-groep, maar deze zijn niet eenduidig aan de hulpwormen toe te schrijuen.

De effecten van Praktisch Pedagogische Gezinsbegeleiding zijn gedeeltelijk afhankelijk van de hulpvragen van de ouders. Ouders die geholpen willen worden bij de gedragsproblematiek of de ontwikkelingsstimulering van hun gehandicapte kind, lijken meer profijt van de hulp te hebben dan ouders wier hulpvragen de gezinsrelaties of de sociale vaardigheden van het kind betreffen. Bij Praktische Thuishulp zijn deze differentièle effecten per subgroep niet aan te tonen vanwege de geringe omvang vân de PT-groep in de nameting. Weekendopvang lijkt voornamelijk positieve effecten te hebben in gezinnen waarin de opvang ter ondersteuning van de ouders en de andere kinderen werd aangevraagd.

De oordelen van de ouders over de vormgeving en de inhoud van de drie hulpvormen zijn in het algemeen positief. De vormgeving van Praktisch Pedagogische Gezinsbegeleiding wordt uitermate positief beoordeeld. Ruim de helft van alle hulpvragen zijn met behulp van PPG beantwoord. Hulpvragen op het gebied van de sociale vaardigheden van het gehandicapte kind zijn echter nauwelijks beantwoord. Ouders met deze hulpvraag en ouders wier hulpvraag de gezinsrelaties betreft, zijn dan ook vaker dan ouders met andere hulpvragen van mening dat het uiteindelijk doel van PPG, i.c. de opvoeding zelf weer aankunnen, niet is bereikt.

De ouders die in de nameting nog Praktische Thuishulp ontvangen, zijn in het algemeen redelijk tevreden over de hulp. Het belangrijkste punt van kritiek lijkt te bestaan uit de afwezigheid van contact met de contactpersoon of (wijk-)coördinator van de Praktische Thuishulpcentrale. Over de mate waarin de hulp aan de verwachtingen van de ouders voldoet, zijn gezien de geringe omvang van de PT-groep nauwelijks uitspraken te doen.

Weekendopvang voldoet voomamelijk aan de verwachtingen van die ouders die zich voor de opvang aanmeldden om zichzelf en hun andere kinderen eens een weekend rust te gunnen. Ouders die de (dreigende) sociale isolatie van het gehandicapte kind ermee hoopten te voorkomen, zijn over de inhoud en vormgeving minder tevreden. De heterogene groepssamenstelling en de geringe frequentie waarmee de kinderen in de respectievelijke accommodaties welkom zijn, zijn voor veel ouders minder positieve aspecten van de hulp, ongeacht hun reden voor aanmelding. 


\section{Discussie en aanbevelingen}

Met het onderzoek waarover dit proefschrift rapporteert, is in de eerste plaats getracht inzicht te verwerven in de determinanten van de stress van ouders van een kind met een verstandelijke handicap. Op basis van de transactionele en cognitieffenomenologische theorie over emoties, stress en coping van Richard S. Lazarus zijn hiertoe drie stressmodellen opgesteld. In het basismodel is verondersteld dat het psychosomatisch onwelbevinden van ouders wordt bepaald door kenmerken van het verstandelijk gehandicapte kind, kenmerken van de ouders, kenmerken van de andere kinderen in het gezin en de concrete problemen van ouders. In het copingmodel is verondersteld dat de wijze waarop ouders met problemen omgaan, eveneens is gerelateerd aan hun psychosomatisch onwelbevinden. In het sociale-steunmodel is tenslotte verondersteld dat, naast de determinanten uit het basismodel, de steun die ouders krijgen van mensen uit hun sociale omgeving eveneens gerelateerd is aan hun psychosomatisch welbevinden. Deze stressmodellen zijn aan de empirie getoetst. $\mathrm{Na}$ een bespreking van de belangrijkste resultaten van dit meer theoretisch georienteerde gedeelte van de studie worden in 10.1 aanbevelingen gedaan voor toekomstig stressonderzoek in het algemeen en voor stressonderzoek onder ouders van een verstandelijk gehandicapt kind in het bijzonder.

In de tweede plaats zijn in deze studie drie relatief nieuwe hulpvormen geèvalueerd in de zorg voor mensen met een verstandelijke handicap en hun directe omgeving: Praktisch Pedagogische Gezinsbegeleiding, Praktische Thuishulp en Weekendopvang. Deze hulpvormen zijn vanaf de zeventiger jaren ontwikkeld als gevolg van de wens van een toenemend aantal ouders geholpen te worden bij het grootbrengen van hun gehandicapte kind in het eigen gezin. De nieuwe hulpvormen beogen het evenwicht te bevorderen tussen de draagkracht van de ouders in deze gezinnen en de draaglast die het leven met een verstandelijk gehandicapt kind met zich kan brengen. De evaluatie van de hulpvormen betreft enerzijds de kenmerken van de gezinnen die deze hulp aanvragen en hun redenen voor aanmelding en anderzijds de effecten van de hulp op 
de stress van ouders en hun cordelen over de hulp. In 10.2 worden eerst de belangrijkste resultaten weergegeven van dit meer op de praktijk gerichte gedeelte van het onderzoek. Daarnat worden aanbevelingen opgesteld voor het onderzoek naar en de inhoud van deze hulpwormen.

\subsection{Stress bij ouders wan een kind met een verstandelijke handicap}

De exploratieve stressmodellen die in hoofdstuk 3 zijn opgesteld ter bepaling van de determinanten van de stress van ouders die een kind met een verstandelijke handicap in het eigen gezin grootbrengen, veronderstellen lineaire, unidirectionele en additieve verbanden tussen de erin opgenomen (blokken van) variabelen. De werkelijkheid in de betreffende gezinnen is ongetwijfeld complexer dan deze modellen impliceren. De continu veranderende relaties tussen mens en omgeving die Lazarus in zijn transactionele visie op stressprocessen als belangrijkste onderwerp van studie benadrukt, benaderen de realiteit in deze gezinnen waarschijnlijk meer. Deze voortdurende terugkoppelingsmechanismen zijn echter nauwelijks in hun totaliteit te onderzoeken en leveren ons inziens bovendien te weinig concrete inzichten en aangrijpingspunten voor de hulpverlening op.

De stressmodellen veronderstellen een zekere hiërarchische ordening tussen sommige erin opgenomen (blokken van) variabelen. Ter toetsing van dit soort modellen zijn longitudinale studies te prefereren boven cross-sectionele studies. Gezien de opzet van het onderhavige onderzoek zou een longitudinale toetsing van de stressmodellen echter alleen voor de ouders in de controlegroep te realiseren zijn geweest. Aangezien van de hulpverlening effecten werden verwacht op verschillende variabelen in de modellen, zouden de ouders in de hulpverleningsgroepen immers niet betrokken kunnen worden bij een longitudinale toetsing van de stressmodellen. De toetsingen van de stressmodellen zijn in de onderhavige studie dan ook gebaseerd op correlaties tussen metingen aan én persoon op eén tijdstip.

In niet-experimentele cross-sectionele studies is de theoretische explicitering van hiërarchisch geordende relaties van essentieel belang. In dit soort studies kan een hierrarchische ordening van variabelen niet worden afgeleid uit de manipulatie van onafhankelijke variabelen, maar alleen uit de mate waarin empirische relaties consistent zijn met de vanuit de theorie afgeleide verbanden (Cook \& Campbell, 1979). Om die reden zijn de variabelen in de stressmodellen en hun onderlinge relaties dan ook geformuleerd op basis van stresstheorieën en gegevens uit (stress)onderzoeken onder ouders van een verstandelijk gehandicapt kind en verwante onderzoeksterreinen.

Wanneer uit analyses op dit soort modellen blijkt dat variabelen die in de theoretische modellen als oorzaak worden beschouwd, inderdaad van invloed zijn op variabelen die als gevolg worden beschouwd, betekent dat echter niet méér dan dat de modellen niet weerlegd zijn. Andere, zelfs theoretisch tegenstrijdige modellen, kunnen consistent zijn met dezelfde dataset. De uitspraak van Pearlin, Lieberman, Menaghan en Mullan (1981) aan het eind van hun onderzoek naar stressprocessen 
illustreert dit punt: "The paradigm represents our own conceptual imagery, and although it is empirically supported, it does not preclude the possibility that there are alternative models which, when tested against the same body of data, would also be supported" (p. 351).

Zoals reeds eerder werd opgemerkt (zie 6.3.1), weerspiegelen de drie stressmodellen even zo vele inhoudelijke visies op de werkelijkheid in gezinnen met een verstandelijk gehandicapt kind. Hoewel, gelet op het voorgaande, conclusies over de richting van de causaliteit in deze modellen met de nodige voorzichtigheid geinterpreteerd dienen te worden, blijkt uit de toetsingen van de stressmodellen dat een gedeeite van de empirische relaties overeenkomt met de uit de theorie afgeleide verbanden.

Van de potentieel stressvolle kenmerken van het verstandelijk gehandicapte kind (zie schema 6.1, blok 1) komen extraverte gedragsproblemen als meest stresserende kenmerken naar voren: ouders ervaren meer concrete problemen naarmate het gehandicapte kind drukker, agressiever, destructiever en ongehoorzamer is, sneller huilt, meer schreeuw- en gilbuien heeft, meer aandacht vraagt en meer problemen rond de maaltijd en het slapen geeft. Daarentegen blijken ouders introverte gedragingen van hun gehandicapte kind, zoals stereotiep en in zichzelf gekeerd gedrag, als minder belastend te ervaren.

Een geringe sociale redzaamheid van het gehandicapte kind draagt, zoals voorspeld (zie 3.2.1), eveneens bij tot de concrete problemen van ouders. Naarmate het gehandicapte kind minder sociaal gericht en minder vriendelijk is, minder gemakkelijk contacten maakt en slechtere relaties met zijn of haar ouders en broer(s) en/of zus(sen) heeft, ervaren ouders meer gezinsverstoring en maken zij zich meer bezorgd over de ontwikkeling van hun andere kinderen. Voorts blijkt dat een ouder, meestal de moeder, zich te kort voelt schieten in de tijd en aandacht die zij aan haar partner en haar andere kind(eren) kan besteden wanneer zij de zorg heeft voor een lichamelijk zwak verstandelijk gehandicapt kind.

Ten aanzien van de onduidelijkheid die in het algemeen bestaat rondom de wijze waarop het verstandelijk niveau van functioneren van het gehandicapte kind gerelateerd is aan de stress van ouders (zie 3.2.1), laten de bevindingen van het onderhavige onderzoek zien dat niet het intelligentiequotient op zich geassocieerd is met de stress van ouders, maar veeleer de beperkingen in vaardigheden die gerelateerd zijn aan een laag niveau van functioneren. Dit zijn met name een gebrek aan sociale en zelfredzaamheidsvaardigheden (zie ook Kraijer, 1988; Van Gemert \& Kraijer, 1985). Deze beperkingen blijken vooral gerelateerd te zijn aan de praktische druk van ouders, i.c. de tijd die zij voor hun eigen bezigheden hebben. De chronologische leeftijd van het gehandicapte kind voegt voorts als zodanig niets toe aan een beter inzicht in de belasting van ouders. Dat jongere gezinnen meer gezinsverstoring ervaren, blijkt te kunnen worden toegeschreven aan het feit dat jongere verstandelijk gehandicapten in deze studie meer stresserende kenmerken hebben dan oudere. Tenslotte blijkt het geslacht van het gehandicapte kind in het geheel niet gerelateerd te zijn aan de concrete problemen van ouders. 
In het onderhavige onderzoek is "stress" geoperationaliseerd alls waargenomen concrete problemen van ouders en als psychosomatisch onwelbevinden (zie 3.1). De stresserende kenmerken van het gehandicapte kind blijken sterker gerelateerd te zijn aan de concrete problemen van ouders dan aan hun psychosomatisch onwelbevinden. Onder de assumpties van het basismodel zijn extraverte gedragsproblemen en een geringe sociale redzaamheid wia hun relaties met eén van de concrete problemen, namelijk gezinsverstoring, wel op indirecte wijze geassocieerd met het psychosomatisch onwelbevinden, maar niet op een directe manier. Een zwakke lichamelijke gezondheid en een gebrek aan sociale en zelfredzaamheidsvaardigheden zijn noch op directe noch op indirecte manieren gerelateerd met het psychosomatisch welbevinden van ouders.

De stresserende kenmerken van het verstandelijk gehandicapte kind, en met name de extraverte gedragsproblemen, blijken uiteindelijk de belangrijkste determinanten te zijin van de stress van ouders. Hieruit mag niet worden geconcludeerd, dat de oorzaak van de belasting van ouders alléen bij het gehandicapte kind ligt. Aangezien opvoeding een langdurend interactief proces tussen ouders en kinderen is en aangezien in cross-sectioneel onderzoek niet is na te gaan waar een keten van achtereenvolgende gebeurtenissen begint, zijn in de stressmodellen ook kenmerken van ouders als exogene variabelen opgevat (zie 3.2.4). Er is dan ook geen causale interpretatie gegeven aan de correlaties tussen de stresserende kenmerken van het gehandicapte kind en enkele kenmerken van de ouders, zoals hun zelfwaardering. Dat in de theoretische modellen de stresserende kenmerken van het gehandicapte kind in een eerste blok zijn ondergebracht en de kenmerken van ouders in een tweede blok, heeft als achtergrond de gedachte dat deze gezinnen juist vanwege de aanwezigheid van een kind met een verstandelijke handicap van andere gezinnen afwijken.

Van de bestudeerde kenmerken van de ouders (zie schema 6.1, blok 2) blijkt de leeftijd van de ouders, zoals verwacht (zie 3.2.2), niet gerelateerd te zijn aan de stress die zij ervaren. Een geringe zelfwaardering blijkt daarentegen wel van groot belang te zijn. Zoals in 2.3 .2 reeds werd verondersteld, is dit persoonlijkheidskenmerk op verschillende manieren van belang voor de uitkomsten van het stressproces bij ouders van een kind met een verstandelijke handicap. Onder de aannames van de stressmodellen draagt een geringe zelfwaardering er op een directe wijze toe bij dat ouders op alle onderzochte terreinen concrete problemen ervaren en dat zij zich in psychosomatisch opzicht slecht voelen. Daarnaast blijkt een geringe zelfwaardering gerelateerd te zijn aan een grote mate van gedragsproblematiek van het gehandicapte kind, een grote mate van gezinsverstoring bij de ouders en een frequent gebruik van een depressieve copingstijl. Onder de assumpties van de stressmodellen draagt een geringe zelfwaardering ook via deze relaties op indirecte manieren bij aan het psychosomatisch onwelbevinden van ouders.

Het opleidingsniveau van ouders respectievelijk de sociale klasse waartoe zij behoren, is eveneens geassocieerd met de stress die zij ervaren. De uitkomsten van het onderhavige onderzoek bevestigen het consistente beeld uit epidemiologische studies, dat mensen uit lagere sociale klassen meer stress ervaren dan mensen uit 
hogere sociale klassen (zie 2.3.1), echter slechts ten dele. Ouders met een lager opleidingsniveau blijken zich in psychosomatisch opzicht slechter te voelen dan ouders met een hoger niveau van opleiding, maar de eerstgenoemde ouders blijken minder praktische druk en minder problemen met betrekking tot de partner te ervaren dan de laatstgenoemde ouders.

Het onderzoek zelf biedt geen afdoende verklaringen voor deze tegenstrijdige bevindingen. Deze bevindingen blijken namelijk niet te kunnen worden toegeschreven aan de gebruikelijke verklaringen voor de verschillen in stress tussen mensen uit uiteenlopende sociale klassen, zoals verschillen in zelfwaardering of in de ernst van de stressvolle omstandigheden waarin men zich bevindt (zie 2.3.1). Het feit dat lager opgeleide ouders zich meer sociaal geïsoleerd voelen, verklaart gedeeltelijk de geconstateerde verschillen in hun psychosomatisch onwelbevinden, maar niet de hieraan tegengestelde verschillen in de emst van de concrete problemen.

Uit de resultaten van het onderhavige onderzoek kan geconcludeerd worden dat er in de wijze waarop ouders hun stress uiten, blijkbaar verschillen zijn die gerelateerd zijn aan hun opleidingsniveau c.q. hun sociale klasse: ouders uit hogere sociale klassen uiten hun belasting in de vorm van concrete problemen en ouders met lagere niveaus van opleiding in de vorm van psychosomatische klachten. Hoewel de onderhavige studie daartoe weinig aanknopingspunten biedt; ligt aan dit verschil wellicht een verschil in coping ten grondslag. Het is niet onmogelijk dat ouders met een lager opleidingsniveau de neiging hebben problemen voor zichzelf te ontkennen en er als gevolg daarvan weinig aan doen om te voorkomen dat deze problemen tot psychosomatische klachten leiden. Hoger opgeleiden zouden zich daarentegen meer bewust kunnen zijn van hun concrete problemen en deze problemen met meer of minder adequate copingstrategieën het hoofd kunnen bieden om geestelijk of lichamelijk onwelbevinden te voorkomen. Het is de moeite waard dit aspect in toekomstig stressonderzoek nader te bestuderen.

In tegenstelling tot de verwachting blijkt niet én van de kenmerken van de andere kinderen in het gezin (zie schema 6.1, blok 3) wan doorslaggevend belang te zijn bij de verklaring van de stress van ouders (zie 3.2.3). Ouders wier andere kinderen jonger zijn, blijken niet meér stress te ervaren dan ouders wier andere kinderen ouder zijn. Ouders van kleinere gezinnen blijken evenveel stress te ervaren als ouders van grotere gezinnen. De plaats van het gehandicapte kind in de kinderrij, zoals jongste, oudste of middelste, is evenmin van belang voor een beter inzicht in de belasting van ouders. Ofschoon een slechte relatie tussen het gehandicapte kind en zijn of haar broer(s) en/of zus(sen) niet bevorderlijk is voor de sfeer in het gezin, blijkt deze relatie te zeer afhankelijk te zijn van de stresserende kenmerken van het gehandicapte kind om naast deze kenmerken nog een eigen bijdrage te leveren aan de verklaring van de verschillen in de belasting tussen ouders.

De bestudeerde concrete problemen van ouders, gezinsverstoring, praktische druk, problemen met betrekking tot de partner en zorgen over de ontwikkeling van de andere kinderen (zie schema 6.1, blok 5), zijn in de stressmodellen enerzijds opgevat 
alls indicatoren voor de aanwezigheid van stress (zie 3.1). Elk van deze problemen blijkt specifieke determinanten te hebben. De concrete problemen zijn anderzijds beschouwd als mogelijke voorlopers voor het ontstaan van psychosomatische klachten (zie schema 6.1, blak 6). De concrete problemen blijken onderling sterk samen te hangen én in hoge mate te correleren met het psychosomatisch onwelbevinden van ouders. Dit multicollineariteitsprobleem is statistisch opgelost door de concrete problemen stapsgewijs in te voeren in de analyse ter voorspelling van het psychosomatisch onwelbevinden. In deze statistische predictie blijkt de mate van gezinsverstoring van primair belang te zijn. Inhoudelijk komt dit overeen met het gegeven dat gezinsverstoring, zoals het gemeten is, het meest algemene concrete probleem is. Bovendien is in het meetinstrument voor dit probleem eveneens de psychische druk van ouders verwerkt (zie 6.1.1). De drie andere, meer specifieke problemen versterken bij ouders waarschijnlijk het idee dat het gehandicapte kind het hele gezinsleven verstoort. Juist dit algemene probleem blijkt meer belastend te zijn dan de meer specifieke concrete problemen.

Het psychosomatisch welbevinden van ouders blijkt voorts slechts in geringe mate afhankelijk te zijn van de wijze waarop $z i j$ in het algemeen hun problemen hanteren (zie schema 6.2, blok 7). Dit is in tegenspraak met de bewering van Lazarus dat de wijze van probleemhantering van meer belang is voor de uitkomsten van stressprocessen dan het probleem op zich (zie 2.2).

Het copingmodel veronderstelt dat het gebruik van (een) bepaalde copingstijl(en) hetzij voor alle ouders ongeacht de belasting die zij ervaren, hetzij alleén voor ouders in de meest stressvolle omstandigheden, positief gerelateerd zou zijn aan hun psychosomatisch welbevinden. Deze laatste, zogeheten moderator-effecten zijn voor geen van de onderzochte copingstijlen aangetroffen: coping vormt geen buffer tegen het ontstaan van psychosomatische klachten wanneer ouders veel concrete problemen hebben.

De veronderstelling, gebaseerd op Lazarus' theorievorming, dat mensen zelf iets kuninen doen om te voorkomen dat problematische situaties tot onwelbevinden leiden, heeft vaak tot hypotheses betreffende moderator-effecten van coping geleid, die echter zelden empirisch worden aangetroffen (zie ook 2.4). Dit is wellicht niet zo verwonderlijk, omdat frequent gebruikte meetinstrumenten voor coping, zoals de Ways of Coping Checklist (WCC) en de Utrechtse Coping Lijst (UCL), meer emotieregulerende dan actieve, op oplossing van het probleem gerichte copingstijlen bevatten (zie ook 2.2). Deze sterke preoccupatie "with defense mechanisms ... has the effect of creating an overemphasis on failure of coping and pathology rather than effectiveness and growth" (Lazarus \& Launier, 1978, p. 311). Het verdient dan ook aanbeveling om alvorens in het vervolg effecten van coping te bestuderen, het totale copingterrein inhoudelijk te analyseren, met speciale aandacht voor probleemgerichte copingstrategieèn, alsmede een op een dergelijke analyse gebaseerd meetinstrument te ontwikkelen (zie cok Van Heck \& Vingerhoets, 1989). 
In het onderhavige onderzoek doet de gebruikelijke ondervertegenwoordiging van probleemgerichte copingstijlen zich des te sterker voor. Voor de meting van coping is gebruik gemaakt van de twee hoogst ladende items uit elk van de zeven subschalen van de UCL (zie 2.2 en 6.1.1). De factor analyse op deze 14 items die het best te interpreteren is, laat vijf factoren zien: de oorspronkelijke UCL-subschaal "actief problemen aanpakken, confronteren" blijkt in de populatie van ouders van een verstandelijk gehandicapt kind niet als een aparte factor te zijn gehandhaafd. Wellicht heeft dit als achtergrond dat deze ouders vaak het gevoel hebben er beter aan te doen situaties maar te accepteren zoals zij zijn (secundaire appraisal). Dit kan ertoe bijdragen dat zij voomamelijk copingstijlen hanteren die juist nít op hun concrete problemen gericht zijn, zoals vermijding, en/of copingstijlen die voomamelijk op emotie-regulatie gericht zijn, zoals een palliatieve reactie of expressie van emoties (zie ook Folkman, Lazarus, Dunkel-Schetter, DéLongis \& Gruen, 1986). Ook de onderzoeksbevindingen van Last (1986) ten aanzien van coping bij ouders van een kind met kanker (zie 3.3), lijken erop te wijzen dat ervaringen met emstige en oncontroleerbare gebeurtenissen veranderingen in copingstijlen tot gevolg kunnen hebben. Het verdient aanbeveling nader onderzoek op dit punt te verrichten.

Het zoeken van sociale steun, een palliatieve reactie op problemen, vermijding van problemen en de expressie van emoties naar aanleiding van moeilijke situaties zijn voorts noch positief noch negatief gerelateerd aan het psychosomatisch welbevinden van ouders. Alleen een frequenter gebruik van de copingstijl "depressief reactiepatroon" is onder de assumpties van het copingmodel gerelateerd aan een grotere mate van psychosomatisch onwelbevinden. Dit is gedeeltelijk te wijten aan het feit dat ouders zich met name somber en piekerend in zich zelf terugtrekken wanneer zij veel gezinsverstoring ervaren en een negatief zelfbeeld hebben. Een depressieve copingstijl is dan ook gedeeltelijk op te vatten als een "barometer" voor of een afspiegeling van de emst van de situatie en de emotionele verwerking ervan (zie ook Feij, Van Kampen, Doom, Resing \& Van den Berg, 1990).

De mediërende rol van de copingstijl depressief reactiepatroon is naar voren gekomen doordat in de onderhavige studie (a) stressvolle omstandigheden en coping als hiërarchisch geordend zijn opgevat en geanalyseerd en niet, zoals gebruikelijk is (zie 2.4), als nevengeschikt; en (b) verschillende hulpbronnen, waaronder persoonlijkheidskenmerken, causaal gerelateerd zijn aan stressvolle omstandigheden, copingstijlen én uitkomsten van het stressproces. Voor een beter inzicht in de wijze waarop coping een rol speelt in stressprocessen wordt voor toekomstig onderzoek dan ook aanbevolen de verbanden tussen stressvolle omstandigheden en coping als hiërarchisch geordend te relateren aan de uitkomsten van stressprocessen en de invloed van hulpbronnen meer uitputtend te anallyseren dan veelal gebruikelijk is.

De copingstijl "depressief reactiepatroon" is niet alleen op te vatten als een "[epiphenomenon] with no real impact on stress and life adaptation" (McCrae \& Costa, 1986, p. 401), maar ook als een probleem op zich. Dit blijkt wit het feit dat ouders die in het algemeen depressief op problemen reageren, zich ook ongeacht de ernst van hun omstandigheden en ongeacht hun persoonlijkheidskenmerken, in psychoso- 
matisch opzicht slechter voelen dan ouders die deze copingstijl minder frequent gebruiken. Deze conclusie is gebaseerd op de toetsingen van het copingmodel en wordt tevens bevestigd door het gegeven dat de positieve effecten van Praktisch Pedagogische Gezinsbegeleiding zich des te sterker voordoen wanneer ouders deze copingstijl gedurende de hulpverleningsperiode minder frequent gaan gebruiken (zie 9.2.3.2). Hulpverleners kunnen hieruit afleiden dat zij zich, wanneer zij een afname in de belasting van ouders beogen, niet alleen dienen te richten op de stresserende kenmerken van het verstandelijk gehandicapte kind, de concrete problemen van ouders en hun zelfwaardering, maar ook op de wijze waarop ouders met problemen omgaan.

De bestudering van het sociale-steunmodel (schema 6.3) laat zien dat de structurele indices voor sociale steun, i,c. burgerlijke staat, totaal aantal steungevenden en lidmaatschap van een geloofsgemeenschap of levensbeschouwelijke groepering (blok 8 a), noch aan de concrete problemen van ouders gerelateerd zijn noch aan hun psychosomatisch welbevinden. Bovendien blijkt dat ouders met veel concrete problemen niet mér profiteren van de objectieve of waargenomen steun uit hun socialle ongeving dan ouders met weinig problemen. Deze bevinding komt niet overeen met de verwachting, dat voor de functionele indices van sociale steun, i.c. partnersteun, steun uit het geloof of de levensbeschouwing en afwezigheid van gevoelens van sociale isolatie (blok 8 b), een modererende invloed aantoonbaar zou zijn (zie 2.3.3).

Wel is gebleken dat het psychosomatisch welbevinden van ouders slechter is naarmate zij zich meer sociaal geïsoleerd voelen. Onder de assumpties van het sociale-steunmodel is dit gedeeltelijk te verklaren vanuit het feit dat ouders vooral het gevoel hebben er alleen voor te staan wanneer zij laag zijn opgeleid en veel concrete problemen hebben. Voor toekomstig onderzoek wordit aanbevolen de medièrende rol van sociale steun nader te bestuderen. Hiertoe dienen de gebruikelijke relatief eenvoudige modellen waarin de invloed van sociale steun veelal onafhankelijk van die van stressvolle omstandigheden wordt geanalyseerd, te worden vervangen door meer complexe modellen waarin tevens verschillende hulpbronnen, zoals sociale klasse en persconlijkheidskenmerken, zijn opgenomen.

De relatie tussen sociale isolatie en psychosomatisch onwelbevinden is niet alleen af te leiden uit de ernst van de concrete problemen en het opleidingsniveau van ouders. Ouders blijken zich ook ongeacht de ernst van hun problemen en hun opleidingsniveau in psychosomatisch opzicht slechter te voelen naarmate zij meer sociaal geïsoleerd zijn. Deze conclusie, die gebaseerd is op de toetsingen van het socialesteunmodell, wordt bevestigd door de analyses ten aanzien van de effecten van Praktisch Pedagogische Gezinsbegeleiding. Hieruit blijkt dat ouders meer van de hulp geprofiteerd hebben naarmate zij zich voorafgaand aan PPG minder geîsoleerd voelden en naarmate zij gedurende de hulpverleningsperiode minder het gevoel hebben gekregen er alleen voor te staan (zie 9.2.3). Hulpverleners zouden er dan ook goed aan doen zich ook op deze gevoelens van sociale isolatie richten. 
Dat sociale isolatie een probleem op zich vormt, was te verwachten. Menig ouder van een verstandelijk gehandicapt kind heeft de ervaring dat familieleden, buren en kennissen zich wat afzijdig houden, dat zij zelf vaak beperkt zijn in bun mogelijkheden andere mensen te bezoeken of dat de andere kinderen in hun sociale contacten belemmerd worden door hun gehandicapte broer of zus. In eerste instantie is sociale isolatie dan ook betrokken bij de meting van de concrete problemen van ouders (zie 6.1.1). Pas in tweede instantie is sociale isolatie uit statistische en inhoudelijke overwegingen opgevat als mogelijk interveniërende variabele in het stressproces. Uit de onderzoeksbevindingen blijkt dat beide interpretaties van sociale steun zinvol zijn in het geval van ouders van een kind met een verstandelijke handicap.

Samenvattend zijn op basis van de bevindingen van de toetsingen van de stressmodellen de volgende aanbevelingen opgesteld ten aanzien van onderzoek naar stress in het algemeen en naar stress bij ouders van een kind met een verstandelijke handicap in het bijzonder:

(1) Het verdient aanbeveling na te gaan of mensen/ouders uit verschillende sociale klassen de stress die zij ervaren op verschillende manieren uiten en of daaraan verschillen in coping ten grondslag liggen.

(2) Ten aanzien van onderzoek naar coping wordt aanbevolen:

(a) een inhoudelijke analyse van het totale copingterrein te verrichten, met specialle aandacht voor actieve, probleemgerichte copingstrategieèn, alsmede op basis daarvan een meetinstrument te ontwikkelen;

(b) na te gaan of emstige, oncontroleerbare gebeurtenissen leiden tot de ontwikkeling van andere patronen van coping, in het bijzonder tot de ontwikkeling van copingstrategieën die gericht zijn op vermijding van problemen respectievelijk op emotie-regulatie;

(c) meer complexe theoretische modellen op te stellen ten aanzien van de manieren waarop stressvolle omstandigheden, coping en diverse hulpbronnen in hun onderlinge samenhang gerelateerd zijn aan verschillende uitkomsten van stressprocessen.

(3) Ten aanzien wan onderzoek naar sociale steun verdient het aanbeveling de medièrende rol van sociale steun nader te bestuderen.

Ten aanzien van de hulpverlening op het gebied van ouders van een kind met een verstandelijke handicap wordt aanbevolen:

(4) niet alleen aandacht te hebben voor de stresserende kenmerken van het gehandicapte kind en de persoonlijkheidskenmerken van de ouders, maar ook in te gaan op de manieren waarop ouders hun problemen hanteren en op gevoelens van sociale isolatie van ouders.

\subsection{Evaluatie van thuiszorg}

De tweede doelstelling van het onderhavige onderzoek heeft betrekking op de evaluatie van Praktisch Pedagogische Gezinsbegeleiding (PPG), Praktische Thuishulp (PT) en Weekendopvang (WO). 
Per hulpvorm worden in 10.2.1 $\mathrm{k} / \mathrm{m} 10.2 .3$ de resultaten van deze evaluaties samengevat. Op basis daarvan worden tevens aanbevelingen opgesteld ten aanzien van toekornstig onderzoek naar deze hulpvormen en ten aanzien van verbeteringen in de inhoud van de hulp.

\subsubsection{Praktisch Pedagogische Gezinsbegeleiding}

Ouders die hulp zoeken bij de afdelingen Praktisch Pedagogische Gezinsbegeleiding van de Sociaal Pedagogische Diensten blijken bij hun aanmelding, zoals voorspeld (zie 5.1 en 7.4.2), meer stress te ervaren dan ouders die, als zij al opvoedingsvragen of -problemen hebben, daarvoor niet de hulp van Praktisch Pedagogische Gezinsbegeleiding inroepen. Deze grotere belasting is te verklaren uit de determinanten van stress in het algemeen (zie ook 10.1): in de PPG-gezinnen hebben de verstandelijk gehandicapte kinderen meer gedragsproblemen en een geringere sociale redzaamheid, behoren de ouders tot een lagere sociale klasse, hebben zij een geringere zelfwaardering, ervaren zij meer concrete problemen, waarop zij bovendien dikwijls met een depressieve copingstijl reageren en voelen zij zich meer sociaal geïsoleerd dan ouders die geen PPG aanvragen. Dit leidt ertoe dat ouders die zich aanmelden voor PPG zich geestelijk en lichamelijk slechter voelen dan ouders die geen beroep doen op Praktisch Pedagogische Gezinsbegeleiding.

De mate waarin PPG-ouders zich belast voelen, blijkt gedeeltelijk afhankelijk te zijn van het specifieke opvoedingsprobleem waarbij zij de hulp van PPG inroepen. Vooral ouders wier hulpvraag de gedragsproblematiek van het gehandicapte kind betreft, voelen zich zwaar belast. Dagelijks terugkerende gedragsproblemen zijn voor het hele gezin ingrijpend en bestaan, als de ouders zich bij PPG aanmelden, al geruime tijd zonder dat zij er adequate oplossingen voor hebben gevonden. Dat ouders met deze hulpvraag zich het meest belast voelen, is in overeenstemming met het gegeven dat de gedragsproblematiek van het verstandelijk gehandicapte kind, onder de assumpties van de stressmodellen, in het algemeen de belangrijkste determinant is van de stress van ouders.

Ouders die PPG inschakelen voor hulp bij de ontwikkelingsstimulering van hun jonge en veelal lichamelijk zwakke gehandicapte kind, voelen zich opvallend meer gesteund door mensen uit hun sociale omgeving dan ouders met andere hulpvragen. Daarentegen voelen ouders die PPG aanvragen om geholpen te worden bij de verbetering van de gezinsrelaties, zich juist meer sociaal geïsoleerd dan ouders met andere hulpvragen. Ouders die zich tot Praktisch Pedagogische Gezinsbegeleiding wenden voor hulp bij het stimuleren van vaardigheden die het gehandicapte kind in staat moeten stellen contacten met mensen buiten het gezin aan te gaan, blijken zich tenslotte niet te onderscheiden van de "gemiddelde" PPG-ouders.

$\mathrm{Na}$ de afsluiting van Praktisch Pedagogische Gezinsbegeleiding blijkt de invloed van de hulpverlening op de stress van de ouders en de determinanten ervan mager te zijn geweest. Verwacht werd dat de hulpverlening alle verschillen met ouders die geen PPG aanvroegen, teniet zou doen. Dat blijkt niet het geval te zijn geweest (zie 
9.2.2.1). Als gevolg van de hulp zijn alleen de sociale redzaamheid en de sociale en zelfredzaamheidsvaardigheden van de verstandelijk gehandicapte kinderen in de PPG-groep meer toegenomen dan van de kinderen die geen PPG hebben gehad. Op basis van de uitkomsten van covariantie analyses zijn alle overige hypotheses ten aanzien van de effecten van $\mathrm{PPG}$ verworpen. Analyses op de verschilscores tussen de voor- en de nameting en analyses op de scores in de nameting alleen maken echter duidelijk dat er gedurende de hulpverleningsperiode wél verbeteringen in de PPG-groep zijn opgetreden en dat de PPG-groep na afloop van de hulpverlening meér op de controlegroep lijkt dan voorafgaand aan de hulp. Dit betreft met name de zelfwaardering van de ouders, enkele concrete problemen, hun gevoelens van sociale isolatie en hun psychosomatisch onwelbevinden (zie 9.2.2.1).

De verbeteringen in de PPG-groep zijn niet groot genoeg geweest om met covariantie analyses te kunnen worden opgespoord c.q. om eenduidig aan de hulpverlening te kunnen worden toegeschreven. Dit is waarschijnlijk te wijten aan het feit dat Praktisch Pedagogische Gezinsbegeleiding niet in staat is gebleken de gedragsproblematiek van de verstandelijk gehandicapte kinderen, zowel voor als na de hulpverlening de belangrijkste determinant van de stress van de ouders, in voldoende mate te reduceren.

Het is maar de vraag of een directe invloed van PPG op deze gedragsproblematiek verwacht mocht worden. Praktisch Pedagogische Gezinsbegeleiding richt zich immers niet met een therapeutische interventie op de behandeling van problemen bij het verstandelijk gehandicapte kind. PPG richt zich in eerste instantie op de ouders en beoogt hun opvoedingscompetentie en probleemoplossend vermogen te vergroten (zie 5.1). De antwoorden op de vraag naar de mate waarin de ouders na de afsluiting van de hulpverlening menen de opvoeding van hun kind zelf weer aan te kunnen (zie 9.2.3.3), geven weliswaar aan PPG deze doelstelling in de meeste gezinnen grotendeels bereikt heeft. Vragen naar de pedagogische kennis en vaardigheden van de ouders en naar hun pedagogische onmacht of frustratie zouden echter een scherper inzicht kunnen geven in de mate waarin de primaire doelstelling van PPG is bereikt. Opname van dit soort vragen in toekomstige evaluaties van deze hulpvorm is dan ook aan te bevelen.

In de doelstelling van PPG wordt impliciet verondersteld dat een groter probleemoplossend vermogen en een grotere opvoedingscompetentie na verloop van tijd leiden tot een afname van de problemen in het gezin. Wanneer deze assumptie juist is, kan een tweede verklaring voor het grotendeels ontbreken van aantoonbare effecten van Praktisch Pedagogische Gezinsbegeleiding op de stress van de ouders liggen in het feit dat de nameting te snel na de afsluiting van de hulpverlening heeft plaatsgevonden. Een tweede nameting, een half jaar of een jaar na de eerste nameting, zou duidelijk kunnen maken of de gedragsproblemen van het kind, de concrete problemen van de ouders en hun gevoelens van sociale isolatie inderdaad zijn afgenomen respectievelijk of hun zelfwaardering en psychosomatisch welbevinden zijn toegenomen. Een tweede nameting is dikwijls moeilijk te realiseren, onder 
andere vanwege uitval van respondenten, en moeilijk te interpreteren vanwege testingeffecten, maar is bij toekomstig onderioek stellig na te streven.

De positieve invloed van Praktisch Pedagogische Gezinsbegeleiding blijkt afhankelijk te zij́n van de aard van de hulpvragen. PPG is een adequate vorm van hulpverlening gebleken voor ouders die hulp zoeken bij de gedragsproblematiek of de ontwikkelingsstimulering van het verstandelijk gehandicapte kind. Bij beide hulpvragen kunnen ouders bovendien beter geholpen worden naarmate zij bij hun aanmelding minder stress ervaren. Dit pleit voor een vroegtijdige signalering van opvoedingsproblemen alsmede voor toekenning van de hulp op een moment waarop ouders de nodige energie hebben om zich voor het welslagen van de hulpverlening in te zetten. Dit zijn belangrijke taken voor deskundigen in en buiten de specifieke zorg- en dienstverlening ten behoeve van mensen met een verstandelijke handicap, zoals het cliènt-gerichte gespecialiseerde maatschappelijk werk en andere deskundigen binnen Sociaal Pedagogische Diensten, hwisartsen, kinderartsen en VTO-teams. Wat de hulp bij de ontwikkelingsstimulering betreft, sluit deze vroegtijdige signalering van opvoedingsproblemen en toekenning van hulp overigens aan bij het leeftijdscriterium dat gehanteerd wordt bij de experimenten met de zogeheten early intervention of vroeghulp: ter voorkoming van onnodige ontwikkelingsachterstand bij het kind en gevoelens van opvoedingsincompetentie en stress bij de ouders, richten deze experimenten zich op kinderen die bij aanmelding niet ouder dan 24 maanden zijn (Federatie van Ouderverenigingen, 1990b; Maan, 1991).

Bij de aanmelding voor PPG respectievelijk de intake dient men tevens oog te hebben voor de bestaande stress van ouders. Dit ter voorkoming van teleurstelling bij ouders en hulpverleners. Alvorens tot uitvoering van PPG over te gaan, kan in sommige gezinnen overwogen worden eerst de draaglast van de ouders te doen verminderen, bijvoorbeeld door een tijdelijk intensiever contact met het gespecialiseerde maatschappelijk werk. door inschakeling van andere hulpverleners, zoals de gezinszorg of Praktische Thuishulp of, bij jonge kinderen, door plaatsing van het kind in een kinderdagverblijf (zie ook De Goede, 1991).

Ouders die Praktisch Pedagogische Gezinsbegeleiding aanvroegen om geholpen te worden bij de hantering van problematische gezinsrelaties, blijken gemiddeld genomen langer hulp te hebben gehad dan ouders met andere hulpvragen. Hoewel velen van hen aangeven dat hun hulpvragen met PPG zijn beantwoord, achten deze ouders zich na afloop van de hulpverlening nog onvoldoende in staat de opvoeding van het gehandicapte kind zelf weer op te pakken. Waarschijnlijk is dit een gevolg van het feit dat hun concrete problemen tijdens de hulpverleningsperiode in hun ogen eerder zijn toe- dan zijn afgenomen. Dit is ofwel toe te schrijven aan het achterwege blijven van een afname in de gedragsproblematiek van het verstandelijk gehandicapte kind (zie 9.2.2.2) ofwel aan een afname in de frequentie van het gebruik van de copingstijl vermijding (zie 9.2.3.2).

Wellicht is Praktisch Pedagogische Gezinsbegeleiding in deze gezinnen toch nog te vroeg afgesloten. De ouders zijn zich weliswaar meer bewust geworden van de 
moeilijke situatie waarin zij zich bevinden, maar voelen zich nog onzeker in de hantering van hun problemen. Het is dan ook aan te bevelen in gezinnen waarin problematische gezinsrelaties de centrale hulpvraag vormen, PPG te continueren totdat de ouders het nodige zelfvertrouwen hebben gekregen respectievelijk totdat hun competentie in het oplossen van problemen daadwerkelijk is toegenomen.

In dit onderzoek blijkt Praktisch Pedagogische Gezinsbegeleiding niet in staat te zijn geweest hulpvragen te beantwoorden op het gebied van de ontwikkeling van de sociale vaardigheden ten behoeve van contacten van het gehandicapte kind met mensen buiten het gezin. In de subgroep van ouders met een hulpvraag op dit terrein zijn geen positieve veranderingen aangetoond. Het is mogelijk dat er verbeteringen hebben plaatsgehad die niet gemeten zijn, bijvoorbeeld op het gebied van het zelfvertrouwen van het verstandelijk gehandicapte kind. Dit lijkt overigens te worden tegengesproken door het feit dat de ouders zich na de afsluiting van de hulpverlening onvoldoende in staat achten de opvoeding van het gehandicapte kind weer zelf op te pakken. Uit gesprekken met hulpverleners is gebleken dat de hulpvraag van deze ouders vaak de strekking heeft vrienden of vriendinnen voor het gehandicapte kind te vinden. Om teleurstellingen te voorkomen, is het dan ook aan te bevelen dat PPG het gezin, bijvoorbeeld na een observatieperiode, wijst op meer geêigende personen of instanties. Men kan hierbij denken aan inschakeling van leiding op scholen en dagverblijven, aan contacten met nivo- en leeftijdgenoten in ontspannings- of sportclubs, of aan meer gerichte interventies, zoals Goldsteintherapieen.

Opvallend bij de evaluatie van Praktisch Pedagogische Gezinsbegeleiding is tenslotte de uitermate positieve beoordeling van de vormgeving van deze hulp door de ouders. Ongeacht de hulpvragen van de ouders, hun oordeel over de inhoud van de hulpverlening en de mate waarin zij zich na afloop van de hulp (nog) belast voelen, spreken zij vrijwel zonder uitzondering positieve oordellen uit over de contacten met de pedagogisch werkende, de wekelijkse en de evaluatiegesprekken, de schriftelijke verslagen, de praktische aanwijzingen en het werken volgens cen vast werkplan. De aandacht die gedurende jaren op landelijk en instellingsnivo aan de methodiekontwikkeling van PPG is besteed, blijkt in dit opzicht zijn vruchten ruimschoots afgeworpen te hebben.

Samenvattend zijn op basis van de evaluatie van de vier bij het onderhavige onderzoek betrokken afdelingen Praktisch Pedagogische Gezinsbegeleiding twee aanbevelingen ten aanzien van toekomstig onderzoek op dit terrein gedaan:

(1) Om na te gaan of de primaire doelstelling van Praktisch Pedagogische Gezinsbegeleiding wordt bereikt, wordt aanbevolen zowel in een voor- als in een nameting vragen op te nemen betreffende de pedagogische competentie en het probleemoplossend vermogen van ouders;

(2) Om na te gaan of de stress van de ouders en de determinanten daarvan op de langere termijn afnemen, wordt aanbevolen een tweede nameting te verrichten, cen half jaar of een jaar na een eerste nameting.

Ten aanzien van de inhoud van de hulpverlening zijn drie aanbevelingen opgesteld: 
(3) Aangezien ouders meer van Praktisch Pedagogische Gezinsbegeleiding profiteren naarmate zij voorafgaand aan de hulp minder stress ervaren, wordt aanbevolen:

(a) opvoedingsproblemen in een vroeg stadium te signaleren;

(b) opvoedingshulp vroegtijdig toe te kennen; en

(c) de reeds aanwezige stress, indien deze groot is, eerst te doen afnemen alvorens opvoedingshulp toe te kennen.

(4) Bij gezinnen waarin problematische gezinsrelaties tén van de hulpwragen is, wordt aanbevolen PPG te laten voortduren tot de ouders voldoende zelfvertrouwen in hun eigen handelen hebben gekregen en/of tot hun vaardigheden in het oplossen wan problemen is toegenomen.

(5) Bij gezinnen met een hulpwraag op het terrein van de ontwikkeling van sociale vaardigheden ten behoeve van contacten van het gehandicapte kind met mensen buiten het gezin, wordt aanbevolen tijdens de intake of, als dat onmogelijk is, zo vroeg mogelijk in de observatieperiode na te gaan of deze hulpvraag het zoeken van vrienden of vriendinnen betreft. Indien dit het geval blijkt te zijn, wordt aanbevolen PPG af te sluiten met een verwijzing naar meer geëigende personen, instanties of clubs.

De aanbevelingen 3(a) en 3(b) hebben betrekking op alle hulpverleners die te maken hebben met (ouders van) kinderen met een verstandelijke handicap, zowel in als buiten de specifieke zorg voor mensen met een verstandelijke handicap. De overige aanbevelingen richten zich meer specifiek op de afdelingen PPG van de Sociaal Pedagogische Diensten. De aanbevelingen $3(c)$ en 5 betreffen gedeeltelijk aanscherpingen van de indicatie-criteria voor PPG.

\subsubsection{Praktische Thuishulp}

De verstandelijk gehandicapte kinderen wier ouders Praktische Thuishulp aanvragen, lijken weinig sociale vaardigheden en een geringe zelfredzaamheid te hebben. Hun ouders lijken tot een hogere sociale klasse te behoren dan ouders die zich bij eventuele praktische problemen niet tot Praktische Thuishulpcentrales wenden. Tevens lijken de eerstgenoemde ouders meer concrete problemen te ervaren, met name meer praktische druk. De ouders hopen, ter verlichting van hun taken, gemiddeld eens per twee weken een beroep te kunnen doen op een vrijwilliger van de centrale, en wel voor oppas, bezigheidsbegeleiding, hulp bij de lichamelijke verzorging van het gehandicapte kind of hulp bij vervoersproblemen.

$\mathrm{Na}$ een jaar blijkt de hulpvraag in een aantal gezinnen van tijdelijke aard te zijn geweest. Andere gezinnen maken, zij het minder frequent dan zij bij hun aanmelding wensten, nog van de hulp gebruik. Praktische Thuishulp lijkt bij deze ouders niet, zoals verwacht, een afname in hun gevoelens van praktische druk te hebben bewerkstelligd, maar wel een toename in hun zelfwaardering. Dit laatste is opvallend: Praktische Thuishulp richt zich immers niet in eerste instantie op vergroting van de zelfwaardering van ouders (zie 5.2). Een verklaring hiervoor kan liggen in het feit dat iemand die tijdelijk een deel van de taken ovemeemt, hiermee onder andere 
duidelijk maakt hoe groot de belasting in feite is. Het besef bij de ouders dat zaj deze belasting gedurende langere tijd alleén hebben kunnen dragen, kan hun zelfwaardering hebben doen toenemen. Vrijwel alle ouders zijn tevreden over de hulp die zij ontvangen en zouden andere ouders aanraden zich met gelijksoortige hulpvragen tot een Praktische Thuishulpcentrale te wenden.

De conclusies ten aanzien van de kenmerken van de PT-gezinnen ten tijde van hun aanmelding en ten aanzien van de effecten van de hulp een jaar later, zijn met enig voorbehoud gepresenteerd, omdat zij zijn gebaseerd op de gegevens van 25 respectievelijk 11 gezinnen. Het is verwonderlijk dat de zes centrales die hun medewerking aan het onderzoek hebben verleend, in de twee jaar durende periode van gegevensverzameling maar zo weinig hulpvragen hebben kunnen honoreren. Het gebrek aan breed inzetbare vrijwilligers en de eisen die ouders stellen aan degene aan wie zij, vaak tijdens hun afwezigheid, de zorg voor hun gehandicapte kind overdragen, lijken de belangrijkste oorzaken hiervan.

Zoals reeds in 5.4 werd opgemerkt, was de gegevenswerwerving ten behoeve van deze studie afgerond vórdat de coordinatie van vrijwilligers ten behoeve van thuishulp in handen kwam te liggen van een daartoe vrijgestelde en betaalde coördinator (zie ook 4.3). Het staat nog te bezien of met een dergelijke coobrdinator het kwantitatieve tekort aan vrijwilligers kan worden teruggebracht. Wel bestaat de indruk dat in een professioneel opgezette werkomgeving de kwaliteit van de hulpverlening planmatiger kan worden bewaakt en verbeterd dan in een pure vrijwilligersorganisatie.

Om tegemoet te komen aan de wensen van de ouders, is het aan te bevelen de vrijwilligers beter voor hun taak toe te rusten. Voorafgaand aan hun werkzaamheden moeten zij goed geïnformeerd worden over de problematiek van gezinnen met een verstandelijk gehandicapte huisgenoot in het algemeen, en over die van het gezin waarin zij geplaatst worden in het bijzonder. Informatieve thema-bijeenkomsten waarin ouders en in de zorg werkzame deskundigen een rol kunnen spelen, kunnen de bekwaamheid van de vrijwilligers verder doen toenemen. Voorts wordt ter bevordering van de kwaliteit van de hulpverlening aanbevolen de viijwilligers te blijven begeleiden wanneer zij bij de gezinnen werkzaam zijn, zodat zij op geregelde tijden hun gevoelens en indrukken kunnen uiten en hun problemen kunnen bespreken. Tevens wordt een geregeld contact tussen de coördinator en het gezin aanbevolen om problemen in de relatie tussen het gezin en de vrijwilliger tijdig te kunnen onderkennen en verhelpen.

Door de coördinator ten behoeve van thuiszorg aan te stellen bij voorzieningen in de eerste lijns gezondheidszorg, bestaat de kans dat weinig aandacht besteed zal worden aan gezinnen met een verstandelijk gehandicapt kind en hun hulpvragen (zie 4.3). Deze hulpvragen lijken zo eenvoudig dat zij wel eens buiten de indicatiecriteria zouden kunnen vallen. Aangezien uit het onderhavige onderzoek geconcludeerd kan worden dat ouders geen hulp bij praktische problemen vragen wanneer zij zich niet in aanzienlijke mate belast voelen, wordt aambevolen praktische druk, i.e. nauwelijks 
tijd hebben voor eigen bezigheden en werkzaamiheden, als indicatiecriterium op te nemen bij de toekenning van thuishulp (zie ook: Centrale Raad van Gezinsverzorging, 1988; Stichting Nederlandse Gehandicaptenraad, 1986).

Samenvattend kan ten aanzien wan onderzoek ter evaluatie van Praktische Thuishulp eén aanbeveling worden opgesteld:

(1) Voor een beter inzicht in de kenmerken van de gezinnen die Praktische Thuishulp aanvragen en in de effecten van de hulp wordt aanbevolen het onderhavige onderzoek te herhalen bij meer PT-centrales c.q. instellingen voor thuiszorg.

Van de twee aanbevelingen die ten aanzien van de inhoud van de hulpverlening zijn opgesteld, heeft de eerste betrekking op de individuele instellingen voor thuiszorg en de tweede op de landelijke organisatie van de thuishulp:

(2) Op instellingsnivo wordt aanbevolen de kwaliteit van de hulp te verbeteren door

(a) mecr aandacht te besteden aan vergroting van de bekwaamheid van de vrijwilligers c.q. van de uitvoerders van de thuishulp; en

(b) meer tijd te besteden aan contacten met de gezinnen.

(3) Op landelijk nivo wordt aanbevolen de drempel van de thuiszorg voor ouders van een kind met een verstandelijke handicap laag te houden, door opname van overbelasting in de vorm van praktische druk als indicatiecriterium.

\subsubsection{Weekendopvang}

Uit de evaluatie van de drie bij de studie betrokken projecten Weekendopvang blijkt dat ouders die hun verstandelijk gehandicapte kind aanmelden voor Weekendopvang, meer gezinsverstoring en praktische druk ervaren en zich meer bezorgd maken over de ontwikkeling van hun andere kinderen dan ouders die zich, als zij al behoefte hebben aan opvang van het gehandicapte kind gedurende de weekends, niet bij de drie projecten aanmelden. Tevens blijken de relaties tussen het gehandicapte kind en zijn of haar broer(s) en/of zus(sen) in gezinnen die Weekendopvang aanvragen slechter te zijn. De grotere concrete belasting van de eerstgenoemde ouders kan niet worden verklaard vanuit het feit dat hun verstandelijk gehandicapte kind meer stresserende kenmerken zou hebben, noch uit een lager opleidingsnivo of een geringere zelfwaardering van de ouders zelf, noch uit het feit dat zij vaker depressief reageren op problemen of zich sociaal meer geïsoleerd voelen. Hun psychosomatisch welbevinden wijkt dan ook niet af van dat van ouders die geen behøefte hebben aan Weekendopvang.

Een gedeelte van de redenen op grond waarvan ouders hun kind voor Weekendopvang aanmelden, blijkt aan te sluiten bij de primaire doelstelling van de betreffende projecten. Ouders hopen op deze wijze zelf tot rust te komen, hun aandacht (meer) vrij te maken voor de andere kinderen in het gezin, activiteiten te ondememen waar zij met het gehandicapte kind erbij nauwelijks toe komen, kortom het gezin tijdelijk te ontlasten van de extra zorg voor het gehandicapte kind. Ouders met dit soort redenen voor aanmelding lijken zich meer belast te voelen dan ouders die hun gehandicapte kind voor Weekendopvang aanmelden om dit, overigens gemiddeld ge- 
nomen oudere kind eens een weekend ontspanning te bezorgen. Gemiddeld hopen alle ouders hun kind eens per én à twee maanden van de Weekendopvang gebruik te kumnen laten maken.

Weekendopvang heeft in dit onderzoek na een jaar geen aantoonbare positieve effecten op de stress van de ouders of de determinanten daarvan. Aangezien ouders die van Weekendopvang gebruik maken, zich voorafgaand aan de hulpverlening niet van "gemiddelde" ouders onderscheidden met betrekking tot de algemene determinanten van stress of hun psychosomatisch welbevinden, waren in deze opzichten nauwelijks positieve effecten te verwachten. De ouders ervoeren alleen meer concrete problemen. Juist daarin lijken verbeteringen te zijn opgetreden, met name wat de relaties tussen de ouders en hun kinderen en de relaties tussen de kinderen onderling aangaat. Hoewel dit in overeenstemming is met de verbeteringen in gezinsrelaties die ouders in een voorstudie rapporteerden (Van Berkum, Bremer, Kok \& Wijffels, 1988), kan de oorzaak van deze verbeterde gezinsrelaties in het onderhavige onderzoek niet eenduidig bij de projecten Weekendopvang worden gelegd (zie 9.4.2.1).

Wellicht vindt het ontbreken van aantoonbare effecten op de concrete problemen van de ouders zijn oorzaak in het feit dat ouders bij de nameting gemiddeld slechts vier weekends ervaring hebben met de Weekendopvang (zie 9.4.3.1). Uit de gesprekken die bij het ophalen van de ingevulde vragenlijsten met de ouders zijn gevoerd (zie $6.2)$, werd onder meer duidelijk dat zij enige tijd nodig hebben om zonder schuldgevoelens ten opzichte van het gehandicapte kind te kunnen genieten van de rust in deze "vrije" weekends en van de mogelijkheden die deze weekends bieden om activiteiten te ondernemen. Een tweede nameting na mér weekends, bijvoorbeeld na nog cens een jaar opvang, zou de positieve invloed van Weekendopvang op de langere termijn al dan niet aantonen en wordt voor een toekomstig onderzoek dan ook aanbevolen.

Een andere verklaring voor het uitblijven van aantoonbare positieve effecten op de concrete problemen van de ouders is te ontlenen aan de wijze waarop de projecten Weekendopvang hun doelstelling trachten te bereiken. Weekendopvang beoogt de ouders en de andere kinderen te ondersteunen door hen zo nu en dan een weekend op adem te laten komen. Dat de projecten daarin geslaagd zijn, blijkt uit het feit dat het merendeel van de ouders aangeeft de "vrije" weekends te gebruiken om tot rust te komen, aandacht aan de andere kinderen te schenken en activiteiten te ondememen waar zij anders nauwelijks toe komen (zie 9.4.3.2).

De ondersteuning van de ouders en de andere kinderen in het gezin vindt echter op een indirecte wijze plaats, namelijk door het gehandicapte kind tijdelijk uit het gezin te halen. Aangezien Weekendopvang niet direct ingaat op de concrete problemen van de ouders of op de gezinsrelaties, kan verondersteld worden dat de opvang vooral tijdens en, zoals uit de voorstudie blijkt (Van Berkum et al., 1988), vlak na de "vrije" weekends een positieve invloed heeft op het welbevinden van de ouders en hun concrete problemen. Gezien de aard en de frequentie van de opvang kan tevens 
verondersteld worden dat meer werstrekkende effecten zich pas op de langere termijn voordoen. Ook om deze reden zou een nameting na nog een jaar Weekendopvang meer uitkomst bieden.

Positieve effecten van deelname aan de Weekendopvang lijken met name te hebben plaatsgehad in gezinnen waarin de reden voor aanmelding aansluit bij de doelstelling van de projecten. Tevens zijn ouders die Weekendopvang aanvroegen ter ondersteuning van hen zelf en hun andere kinderen in het algemeen meer tevreden over de inhoud en vooral over de vormgeving van de opvang dan ouders die hoopten hun verstandelijk gehandicapte kind met de Weekendopvang uit zijn of haar sociale isolement te kurnen halen. Laatstgenoemde ouders lijken enigszins teleurgesteld in de opvang: hun kind brengt de weekends naar hun idee niet met leeftijdgenoten door maar met te jonge andere kinderen, er is te weinig ruimte en privacy voor deze oudere kinderen en de activiteiten die tijdens de weekends ondemomen worden, zijn meer afgestemd op jongere dan op oudere kinderen.

Weekendopvang zou meer gericht moeten zijn op oudere kinderen. Aangezien ouders van jongere gehandicapte deelnemers eveneens moeite hebben met de ook qua leeftijd heterogeen samengestelde groepen (zie 9.4.3.1), verdient het aanbeveling eens per 6 tot 8 weken een apart weekend te organiseren voor oudere deelnemers, vanaf ongeveer 14 jaar. Tevens wordt aanbevolen de maximum leeftijdsgrens van 18 respectievelijk 20 jaar die de projecten nu hanteren (zie 5.3), te laten vervallen om ook oudere kinderen en hun ouders in aanmerking te laten komen voor de opvang. Dat deze oudere ouders behoefte hebben aan dit soort opvang, blijkt wel uit het feit dat ruim een kwart van de gebruikers van de logeerhuizen, waar de doelstelling van de hulp identiek is, ouder dan 20 jaar is (Federatie van Ouderverenigingen, 1990a).

Een tweede aanbeveling betreft de lichamelijk zwakke dan wel meervoudig gehandicapte deelnemers. Om tegemoet te komen aan de kritiek van de ouders van deze kinderen (zie 9.4.3) wordt aanbevolen hen, hetzij mondeling hetzij door middel van een kort schriftelijk verslag, beter te informeren over de wijze waarop hun kind het weekend heeft doorgebracht, te meer daar het kind het vaak zelf niet kan vertellen. Hun kritiek op de planning zou verholpen kunnen worden door hen zelf te laten aangeven op welke data zij van de opvang gebruik willen maken en hen bijtijds in kennis te stellen van de mogelijkheden daartoe.

De bij het onderzoek betrokken projecten kunnen, zoals gezegd (zie 5.3), weinig lichamelijk zwakke kinderen opnemen en zeker niet tegelijkertijd, vanwege de vereiste accommodatie, deskundigheid van de leiding en de extra tijd die deze deelnemers vragen. Lichamelijke ongezondheid is een factor die een rol speelt bij de belasting van ouders in het algemeen (zie 7.1). Hoezeer juist ook ouders van deze kinderen behoefte hebben aan tijdelijke opvang van het kind buiten het gezin, moge blijken uit het feit dat ongeveer de helft van de gebruikers van de logeerhuizen een bijkomende motorische of zintuiglijke handicap heeft dan wel meervoudig gehandicapt is (Federatie van Ouderverenigingen, 1990a). Voor de projecten Weekendopvang worden dan ook aanpassingen in de accommodaties en een grotere deskundig- 
heid in de leiding aanbevolen zodat meer lichamelijk zwakke of meervoudig gehandicapte kinderen kunnen worden opgevangen.

Een derde aanbeveling betreft de frequentie van deelname. Evenals in het vooronderzoek (Van Berkum et al., 1988) blijkt ongeveer drie kwart van de gezinnen minder frequent in aanmerking te komen voor de opvang dan de ouders bij hun aanmelding wenselijk achtten. Hoewel gezimnen vaker een weekend opvang krijgen toegewezen naarmate ouders zich zwaarder belast voelen, zijn het met name ouders van gedragsmoeilijke kinderen die kritiek hebben op de te lage frequentie van deelname. Bovendien zijn het juist deze ouders die genieten van de rust in de "vrije" weekends en van de mogelijkheden dan activiteiten te ontplooien die zij anders nauwelijks kunnen ondernemen. Aangezien de gedragsproblematick van het verstandelijk gehandicapte kind, onder de assumpties van de stressmodellen, in het algemeen de belangrijkste oorzaak van stress bij ouders is, wordt aanbevolen juist deze ouders frequenter van de Weekendopvang gebruik te laten maken.

Samenvattend is op grond van de onderzoeksbevindingen eén aanbeveling opgesteld ten aanzien van toekomstige evaluaties van Weekendopvang:

(1) Om na te gaan of Weekendopvang op de langere termijn effecten op de stress van ouders heeft, met name op hun concrete problemen en op de gezinsrelaties, wordt een (tweede) nameting na nog een jaar opvang aanbevolen.

Ten aanzien van de inhoud van de hulpverlening zijn drie aanbevelingen opgesteld:

(2) Wat de leeftijd van de deelnemers betreft, wordt aanbevolen:

(a) aparte weekends te organiseren voor jongere en oudere kinderen met een verstandelijke handicap (leeftijdsgrens ongeveer 14 jaar); en

(b) de huidige maximum leeftijdsgrens te laten vervallen, zodat ook kinderen die ouder zijn dan 18 respectievelijk 20 jaar van de Weekendopvang gebruik kunnen maken.

(3) Om meer lichamelijk zwakke of meervoudig gehandicapte kinderen in aanmerking te laten komen voor Weekendopvang, worden aanpassingen in de betreffende accommodaties en meer deskundigheid in de leiding aanbevolen.

(4) Ten einde ouders van een verstandelijk gehandicapt kind met aanzienlijke gedragsproblemen beter te kunnen ontlasten, wordt aanbevolen juist deze ouders in de gelegenheid te stellen frequenter van Weekendopvang gebruik te maken.

De aanbevelingen ten aanzien van de inhoud van de hulpverlening hebben in eerste instantie betrekking op de projecten Weekendopvang die aan het onderhavige onderzoek hebben deelgenomen en op soortgelijke projecten. De uitvoering van deze aanbevelingen impliceert een aanzienlijke uitbreiding van de mogelijkheden voor wederkerende kortdurende opvang van het gehandicapte kind buiten het gezin. De capaciteit van de drie projecten kan nauwelijks worden uitgebreid. Bovendien is de zorg voor verstandelijk gehandicapten en het gezin waartoe zij behoren een zorg van alle regionale hulpverieners en voorzieningen en een zorg voor de landelijke overheid. Daarom wordt ervoor gepleit het totaal aantal beschikbare plaatsen voor 
tijdelijke opvang buitenshuis wit te breiden. De functies "logeren" en "verzorgd verblijf woor korte duur" bieden hiertoe de mogelijkheden.

\subsubsection{Besluit: Evaluatie van thuiszorg}

De gegevens in dit proefschrift maken duidelijk dat Praktisch Pedagogische Gezinsbegeleiding, Praktische Thuishulp en Weekendopvang worden aangevraagd door en toegewezen aan gezimnen waarvoor deze hulpvormen bestemd zijn. Dit is een eerste indicatie van de kwaliteit van deze hulp. Voorts is gebleken dat twee van deze hulpwormen hun primaire doelstelling bereiken: het merendeel van de ouders die Praktisch Pedagogische Gezinsbegeleiding hebben gehad, meent na de afsluiting van de hulpverlening de opvoeding van het gehandicapte kind weer grotendeels zelf aan te kunnen en het merendeel van de ouders die Weekendopvang krijgen, gebruikt de "vrije" weekends zoals deze bedoeld zijn, namelijk om tot rust te komen, de andere kinderen in het gezin aan bod te laten komen en activiteiten te ontplooien waar zij anders moeilijk toe komen. Praktische Thuishulp bereikt zijn beoogde doel nauwelijks: de bij het onderzoek betrokken centrales bereiken slechts weinig gezinnen. Een derde indicatie voor de kwaliteit van de geboden zorg heeft well op alle drie hulpvormen betrekking: de ouders zijn redelijk tot zeer positief in hun oordelen over de hulp.

Uit de gegevens is tenslotte niet te concluderen dat de drie hulpvormen hun uiteindelijke doelstelling hebben waargemaakt: de hulpwormen zijn er in een jaar tijd niet aantoonbaar in geslaagd de balans te bevorderen tussen de draaglast en de draagkracht van de ouders die een beroep op hen doen. Voor toekomstige onderzoekers lijkt het de moeite waard na te gaan of dit te wijten is aan beperkingen in de hulpverlening, aan beperkingen van de in deze studie gebruikte onderzoeksmethodiek dan wel aan de, ook blijkens dit onderzoek, niet te onderschatten zwaarte van de draaglast van het leven met een verstandelijk gehandicapt kind. 
Het doel van de studie waarover dit proefschrift rapporteert, is tweeledig: bepaling van de determinanten van de stress van ouders die thuis een kind met een verstandelijke handicap grootbrengen en evaluatie van recentelijk ontwikkelde hulpvormen in de zorg - en dienstverlening ten behoeve van mensen met een verstandelijke handicap.

In hoofdstuk 1 wordt het eerste, theoretisch georiènteerde gedeelte van het onderzoek kort aan de orde gesteld door de introductie van de transactionele, cognitieffenomenologische theorie over emoties, stress en coping van Richard S. Lazarus. Tevens wordt kort ingegaan op het tweede, meer op de praktijk gerichte gedeelte van het onderzoek door een beschrijving van ontwikkelingen in de gezondheidszorg als geheel en de zwakzinnigenzorg in het bijzonder. Vanaf de jaren zestig hebben deze ontwikkelingen ertoe bijgedragen dat steeds meer ouders hun verstandelijk gehandicapte kind in het eigen gezin willen grootbrengen. Ouders van een verstandelijk gehandicapt kind zijn lange tijd als een homogene groep beschouwd, wier psychisch onwelbevinden als een onvermijdelijke reactie op de geboorte van dit kind werd opgevat. Sinds de zeventiger jaren trachten onderzoekers onder andere naar aanleiding van Lazarus' stresstheorie inzicht te verwerven in de verschillen in stress tussen deze ouders die in de praktijk te constateren zijn.

Hoofdstuk 2 gaat dieper in op Lazarus' stresstheorie. Volgens Lazarus is er sprake van psychologische stress wanneer iemand inschat dat een specifieke situatie of gebeurtenis de hulpmiddelen die hem of haar op dat moment ter beschikking staan, te zeer belast of overschrijdt en wanneer deze situatie of gebeurtenis in de cognitieve taxatie van de persoon in kwestie zijn of haar welbevinden bedreigt. $\mathrm{Na}$ een bespreking van vele onderzoeken die op basis van de ideeèn van Lazarus en zijn groep van medewerkers zijn uitgevoerd, wordt vastgesteld dat er weinig duidelijkheid en eenstemmigheid bestaat omtrent de definiëring en in het verlengde daarvan de operationalisering van belangrijke elementen uit Lazarus' theorie, zoals cognitieve appraisal, coping en hulpbronnen, waaronder utilitaire bronnen, persoonlijkheidskenmerken en sociale steun. Bovendien acht Lazarus een zeer grote hoeveelheid variabelen van belang voor de uitkomsten van stressprocessen. Dit maakt zijn theorie inhoudelijk aantrekkelijk, maar heeft er tevens toe bijgedragen dat onderzoekers meestal slechts een beperkt gedeelte van de totale theorie bestuderen. Over de wijze waarop een specifieke gebeurtenis of situatie uiteindelijk de uitkomsten van stressprocessen beïnvloeden, is dan ook weinig met zekerheid te voorspellen.

In hoofdstuk 3 worden exploratief drie hiërarchisch geordende stressmodellen opgesteld ten aanzien van stress bij ouders van een kind met een verstandelijke handicap. Het eerste zogeheten basismodel veronderstelt dat de mate waarin ouders concrete problemen ervaren, i.c. gezinsverstoring, praktische druk, problemen met 
betrekking tot de partner en zorgen over de ontwikkeling van de andere kinderen in het gezin, afhankelijk is van: (a) kenmerken van het verstandelijk gehandicapte kind, i.c. zijn of haar geslacht, leeftijd, verstandelijk niveau van functioneren, lichamelijke gezondheid, gedragsproblemen, sociale redzaamheid en zelfnedzaamheid; (b) kenmerken van de ouders, i.c. hun leeftijd, sociale klasse/opleidingsniveau en zelfwaardering; en/of (c) kenmerken met betrekking tot de andere kinderen in het gezin, i.c. hun leeftijd, aantal, relatie met hun gehandicapte broer of aus en de plaats van het gehandicapte kind in de kinderrij. In dit model wordt tevens verondersteld dat het uiteindelijk psychosomatisch welbevinden van ouders direct afhankelijk is van hun concrete problemen en direct of indirect van kenmerken wan het verstandelijk gehandicapte kind, de ouders en/of de andere kinderen.

In het tweede model, het copingmodel, wordt verondersteld dat de wijze waarop ouders in het algemeen reageren op hun problemen naast de determinanten uit het basismodel eveneens gerelateerd is aan hun psychosomatisch welbevinden. Het derde model, het sociale-steurimodel, veronderstelt tenslotte dat de inbedding van ouders in sociale netwerken en/of de subjectieve ervaring door de sociale omgeving ondersteund te worden, naast de determinanten uit het basismodel eveneens geassocieerd is met hun psychosomatisch welbevinden.

Hoofdstuk 4 gaat nader in op recente ontwikkelingen in de zorg-en dienstverlening ten behoeve van mensen met een verstandelijke handicap en het gezin waartoe zij behoren. Eerst worden enkele knelpunten belicht in de structuur en het functioneren van de zwakzinnigenzorg die de deelnemers aan de Conferentie Gezinsbegeleiding (1977) als obstakels noemden voor het thuis grootbrengen van een kind met een verstandelijke handicap: de afstemming van thet hulpaanbod op de hulpvraag, de samenhang in het hulpaanbod, de houding van hulpverleners en ouders tegenover elkaar en enige lacunes in de hulpverlening, namelijk ten aanzien van hulp bij de opvoeding van het verstandelijk gehandicapte kind, hulp bij praktische problemen en tijdelijke opvang van het kind buiten het gezin. Dit hoofdstuk gaal voorts in op de maatregelen en nota's waarmee de overheid sinds 1978 heeft getracht vorm te geven aan haar beleid ten aanzien van mensen met een verstandelijke handicap. Deze hebben ertoe bijgedragen dat een belangrijk deel van de belemmeringen voor ouders om hun kind thuis op te voeden, in de loop van de jaren tachtig zijn opgeheven.

Hoofdstuk 5 beschrijt de organisatie, de doelstellingen en doelgroepen en de werkwijze van drie nieuwe vormen van gezinsbegeleiding die vanaf de zeventiger jaren zijn ontstaan. Praktisch Pedagogische Gezinsbegeleiding (PPG) tracht de draagkracht van ouders te doen toenemen door vergroting van hun opvoedingscompetentie en probleemoplossend vermogen. Deze hulp wordt aangevraagd door en toegewezen aan ouders die vragen en problemen hebben ten aanzien van de opvoeding van en de omgang met het verstandelijk gehandicapte kind. Praktische Thuishulp (PT) tracht de draaglast van ouders (tijdelijk) te verminderen door hun hulp te bieden bij praktische problemen, zoals oppas, bezigheidsbegeleiding van het kind en hulp bij de lichamelijke verzorging van het kind. Weekendopvang (WO) tracht de draaglast van ouders te verminderen door het gehandicapte kind zo nu en dan een 
weekend in een vertrouwde omgeving te laten logeren. Op basis van de beschrijvingen van deze hulpvormen zijn hypotheses opgesteld ten aanzien van de kenmerken van de gezinnen die de respectievelijke hulpvormen aanvragen en de effecten van de hulp op de stress van ouders en de determinanten ervan.

Hoofdstuk 6 gaat in op de methode die ontwikkeld is om de theoretische en de praktische vraagstelling te kunnen beantwoorden. Op basis van stresstheoretische literatuur, onderzoeken naar stress bij ouders van een verstandelijk gehandicapt kind, de te bestuderen hulpvormen en gesprekken met ouders en hulpverleners is een uitgebreide vragenlijst geconstrueerd. In het algemene gedeelte van de vragenlijst zijn alle theoretische concepten uit de stressmodellen geoperationaliseerd, het specifieke gedeelte bevat vragen over de hulpvormen. De vragenlijst is voorgelegd aan ouders die zich vanaf januari 1988 aanmeldden bij de bij het onderzoek betrokken afdelingen Praktisch Pedagogische Gezinsbegeleiding en projecten Praktische Thuishulp en Weekendopvang alsmede aan een controlegroep van ouders die geen gebruik van deze hulpvormen maakten of wilden gaan maken. Het algemene gedeelte van de lijst is zowel in de voormeting als in de nameting een jaar later aan alle ouders voorgelegd. Het specifieke gedeelte is in de voormeting aan alle ouders voorgelegd; in de nameting hebben de ouders alleen vragen beantwoord die betrekking hebben op de hulp waarvan zij gedurende het jaar ervoor gebruik maakten. De nametingen zijn in februari 1991 afgerond. Dit hoofdstuk gaat tevens in op de analyses die gebruikt zijn on de vraagstellingen te kunnen beantwoorden.

Hoofdstuk 7 bevat de resultaten van de analyses die zijn uitgevoerd om na te gaan welke variabelen uit het basis-, coping- respectievelijk sociale-steunmodel de variantie kunnen verklaren in het psychosomatisch welbevinden van ouders. Ten aanzien van het basismodel zijn met multiple discriminant analyses de twaalf onderzochte potentieel stressvolle kenmerken van het verstandelijk gehandicapte kind gereduceerd tot vier kenmerken die geassocieerd zijn met de concrete problemen van ouders: extraverte gedragsproblemen, een geringe sociale redzaamheid, geringe sociale en zelfredzaamheidsvaardigheden en een slechte lichamelijke gezondheid. Voorts blijkt uit multiple regressie analyses dat het psychosomatisch onwelbevinden van ouders groter is naarmate zij meer gexinsverstoring ervaren, een geringere zelfwaardering hebben en op een lager niveau zijn opgeleid. Ook een grotere mate van gedragsproblematiek en een geringere sociale redzaamheid van het verstandelijk gehandicapte kind dragen bij tot het psychosomatisch onwelbevinden van ouders en wel op indirecte wijze, via de gezinsverstoring die ouders ervaren.

Ten aanzien van het copingmodel blijkt dat opname van de vijf onderzochte copingstijlen, i.c. een depressief reactiepatroon, sociale steun zoeken, een palliatieve reactie, vermijding en expressie van emoties, een toename in het totale percentage verklaarde variantie in het psychosomatisch onwelbevinden tot gevolg heeft. Deze toename is alleen toe te schrijven aan de copingstijl "depressief reactiepatroon". Ouders die deze copingstijl frequenter gebruiken, blijken zich geestelijk en lichamelijk slechter te voelen dan ouders die minder vaak depressief op problemen reageren, ongeacht de omstandigheden waarin zij zich bevinden. Daarnaast medieert een 
depressieve copingstijl, onder de assumpties van het copingmodel, tussen een grote mate van gezinsverstoring en een geringe zelfwaardering van ouders enerzijds en hun psychosomatisch onwelbevinden anderzijds.

Ten aanzien van het sociale-steunmodel blijkt dat het psychosomatisch onwelbevinden van ouders beter wordt voorspeld na opname van de zes indices voor sociale steun, i.c. burgerlijke staat, partnersteun, totaal aantal steungevenden, lidmaatschap van een geloofsgemeenschap of levensbeschouwelijke groepering, steun uit het geloof of de levensbeschouwing en sociale isolatie, dan wanneer alleen de determinanten uit het basismodel bij de analyse worden betrokken. Dit effect komt geheel voor rekening van eén van de indices, namelijk sociale isolatie. Gevoelens van sociale isolatie zijn, onder de assumpties van het sociale-steunmodel, op directe wijze gerellateerd aan het geestelijk en lichamelijk onwelbevinden van ouders. Tevens voelen ouders zich meer sociaal geïsoleerd naarmate zij meer gezinsverstoring ervaren en een lagere opleiding hebben afgerond, hetgeen op indirecte wijze bijdraagt aan hun psychosomatisch onwelbevinden. In tegenstelling tot hetgeen uit Lazarus' theorievorming afgeleid kan worden, blijken coping en sociale steun ouders niet te beschermen tegen psychosomatisch onwelbevinden wanneer zij veel concrete problemen ervaren.

De hoofdstukken 8 en 9 bevatten de resultaten van de analyses die zijn uitgevoerd ter evaluatie van de drie hulpvormen. Uit hoofdstuk 8 komt naar voren dat ouders die Praktisch Pedagogische Gezinsbegeleiding aanvragen, zoals voorspeld, meer concrete problemen ervaren en zich in psychosomatisch opzicht slechter voelen dan ouders die deze hulp niet aanvragen (controlegroep). Deze zwaardere belasting is te verklaren uit de determinanten die onder de assumpties van de stressmodellen in het algemeen de stress van ouders beïnvloeden. Dit betekent dat de grotere belasting van de ouders die zich aanmelden voor Praktisch Pedagogische Gezinsbegeleiding uiteindelijk is te wijten aan de grote gedragsproblematiek van hun verstandelijk gehandicapte kind. De hulpvragen in deze groep betreffen de gedragsproblemen van het kind, zijn of haar ontwikkelingsstimulering, de gezinsrelaties en de ontwikkeling van de sociale vaardigheden van het kind.

Ouders die Praktische Thuishulp aanvragen, hebben, zoals verwacht, in het algemeen een hoog niveau van opleiding en ervaren veel praktische druk. Hun gehandicapte kind is weinig sociaal vaardig en weinig zelfredzaam. Deze ouders vragen voomamelijk oppas en bezigheidsbegeleiding aan om hun taken te verlichten. Ouders die Weekendopvang aanvragen, blijken, zoals voorspeld, meer gezinsverstoring en praktische druk te ervaren en zich meer bezorgd te maken over de ontwikkeling van hun andere kinderen dan ouders die zich niet voor deze hulp aanmelden. Aangezien er geen verschillen tussen beide groepen blijken te bestaan in de determinanten van deze concrete problemen, is niet aangetoond dat het psychosomatisch welbevinden bij de ouders die Weekendopvang aanvragen slechter is dan bij de ouders in de controlegroep. Een gedeelte van de redenen van ouders om Weekendopvang aan te vragen, betreft de primaire doelstelling van de projecten Weekendopvang, i.c. ondersteuning van hen zelf en hun andere kinderen. Andere ouders blijken de opvang 
vooral aan te vragen om het (dreigende) sociale isolement van hun oudere gehandicapte kind te doorbreken.

Hoofdstuk 9 behandelt de effecten van en de oordelen over de hulpvormen. Praktisch Pedagogische Gezinsbegeleiding blijkt de sociale redzaamheid en de vaardigheden ten aanzien van sociaal gedrag en zelfredzaamheid van de verstandelijk gehandicapte kinderen aanzienlijk te doen toenemen. De geconstateerde verbeteringen in het gedrag van het gehandicapte kind, de zelfwaardering van de ouders, hun gevoelens van sociale isolatie, concrete problemen en psychosomatisch welbevinden zijn niet eenduidig aan de hulpverlening toe te schrijven, in tegenstelling tot hetgeen voorspeld werd. Ouders met hulpvragen op het gebied van de gedragsproblematiek en de ontwikkelingsstimulering van het gehandicapte kind hebben meer profijt van de hulp dan ouders met andere hulpvragen. De ouders blijken zeer positief te oordelen over de inhoud en de vormgeving van Praktisch Pedagogische Gezinsbegeleiding.

Praktische Thuishulp blijkt een positieve invloed te hebben op de zelfwaardering van de ouders, maar reduceert hun gevoelens van praktische druk niet, zoals werd voorspeld. De ouders zijn redelijk tot zeer positief over de inhoud en de vormgeving van de hulp. Weekendopvang blijkt geen aantoonbare invloed op de stress van ouders of de determinanten daarvan te hebben. Dit in tegenstelling tot hetgeen voorspeld werd. Er zijn weliswaar verbeteringen in de gezinsrelaties te constateren, maar deze zijn niet eenduidig aan de opvang toe te schrijven. Weekendopvang voldoet vooral aan de verwachtingen van die ouders die de hulp aanvroegen ter ondersteuning van hen zelf en hun andere kinderen. De ouders die zich aanmeldden om de sociale isolatie van hun gehandicapte kind te doorbreken, zijn minder positief over de inhoud en vormgeving van de hulpverlening.

Hoofdstuk 10 bevat de conclusies en de aanbevelingen van de studie. Ten aanzien van de stressmodellen wordt onder andere opgemerkt dat een inhoudelijke analyse van het totale copingterrein, uitmondend in een classificatieschema en een meetinstrument, verder onderzoek op dit gebied kan stimuleren en meer inzicht kan bieden in de wijze waarop coping een rol speelt in stressprocessen. Tevens wordt opgemerkt dat onderzoekers meer recht zouden doen aan Lazarus' bijdrage aan de theorievorming over stress wanneer zij meer complexe coping-en sociale-steunmodellen zouden opstellen waarin de variabelen als hiërarchisch geordend worden opgevat en geanalyseerd. Ten aanzien van de bestudeerde hulpvormen worden onder andere enige verklaringen naar voren gebracht voor de teleurstellende resultaten met betrekking tot de effecten van de hulp op de stress van ouders en de determinanten daarvan. Voorts zijn aanbevelingen opgesteld voor toekomstig onderzoek naar deze hulpvormen en aanbevelingen ter verbetering van de inhoud van de hulp, waaronder aambevelingen ter verscherping van de indicatiecriteria. 
The purpose of this study is twofold: to investigate the determinants of parental stress in raising a mentally retarded child at home and to evaluate recently developed programs in the care for mentally retarded persons and their families. Chapter 1 introduces Richard S. Lazarus' transactional, cognitive-phenomenological theory on emotions, stress and coping and developments in general health care and in the care for mentally retarded persons in particular. From the sixties onwards, these developments converged with the wishes of parents to raise their mentally handicapped child in their own environment. The assumption has formerly been made that parents of mentally retarded children form a homogeneous group who are inevitably psychopathologically disturbed as a reacton to the handicapped child's birth. It was not until the seventies that researchers, inspired by Lazarus' theoretical views on stress processes, devoted themselves to conducting studies aimed at explaining the diversity in parental stressreactions reported from clinical practice.

Chapter 2 focuses on Lazanus' theory on stress. Lazarus defines psychological stress as a particular relationship between a person and the environment that is appraised by the person as taxing or exceeding the resources available to him or her and endangering his or her well-being. An extensive review of studies based on Lazarus' theoretical points of view leads to the conclusion that key concepts in this theory, such as cognitive appraisal, coping and coping resources (e.g. utilitarian resources, personality characteristics and social support), are not clearly and unequivocally defined and operationalized. The sheer number of variables Lazarus considers to be of interest for the adaptational outcomes of stress processes adds to the theory's appeal. It also contributes to the fact that researchers generally restrict themselves to explore limited segments of his theory. For these reasons, predictions about how and why a specific stressful situation influences adaptational outcomes of stress processes can hardly be made.

In chapter 3 three causal models are formulated relating to stress in parents of mentally retarded children. The first, basic stress model assumes that the extent to which parents actually experience problems, e.g. family disruption, practical problems, problems with spouse and concerns about their other children's development, is directly determined by: (a) the mentally retarded child's characteristics, i.e. sex, age, intellectual level of functioning, physical health, behavior problems, social functioning and self-care skills; (b) parent attributes, i.e. age, social class/educational level and self-esteem; and/or (c) sibling factors, i.e. age, number, relationship with their handicapped brother or sister and ordinal position of the mentally retarded child (birth order). This model further assumes that the parents' psychological and physical well-being is directly determined by their actual problems and is directly or indirectly determined by the handicapped child's characteristics, parent attributes and/or sibling factors. 
The second model, the coping model, assumes that in addition to the basic model's determinants the ways parents generally cope with stressful situations also affect their overall well-being. The third model, the social-support model, assumes that in addition to the basic model's determinants being part of social networks and/or perceiving social support also influences parental psychological and physical wellbeing.

In chapter 4 recent developments in the Dutch care for mentally retarded persons and their families are outlined. Structural and functional problems designated by the Family Support Conference (1977) as obstacles in raising a mentally retarded child in the home environment are reviewed. These include: (a) services supplied do not meet parental needs; (b) the service system lacks coherence; (c) service providers and parents need to change their attitudes; and (d) three gaps in the service supply system have to be filled: parents need pedagogical assistance, in-home respite care programs and out-of-home respite care programs during the weekends. This chapter further reviews government policies regarding the care for mentally retarded persons and their families. It is concluded that partly as a consequence of departemental regulations many obstacles for parents to raise their handicapped child in their own families have been removed throughout the eighties.

Chapter 5 reviews the organisation, objectives, target groups and procedures of three family support services developed in the seventies. Practical pedagogical family support programs (PPG) aim to enhance parental resilience by increasing the parents" pedagogical competence and problem-solving skills. Parents with a mentally retarded child who apply for these programs are confronted with pedagogical questions and problems they are unable to solve without professional guidance. Inhome respite care services (PT) are set up to alleviate the parents' burden of care by assisting the parents in handling practical problems at home. These programs generally include baby-sitting services, recreational activities for the handicapped children and assistance for the parents in the physical care for the handicapped child. Programs providing out-of-home respite care during the weekends (WO) aim to reduce parental strains by placing the mentally retarded child out of the home for the weekend. On the basis of this review hypotheses have been formulated regarding the characteristics of families applying for these programs as well as hypotheses concerning the programs' effects on parental stress and its determinants.

In chapter 6 the methods used in this study are described. A detailed questionnaire is constructed on the basis of stress theories, studies on stress in parents of mentally retarded children, the programs under study and interviews with parents and service providers. In the questionnaire's general sections the theoretical stress concepts have been operationalized. Questions on each of the programs under study are included in the questionnaire's more specific sections. Parents who apply for one of the programs participating in the study and a control group of parents who do not (wish to) apply for these programs have been contacted to complete the questionnaire. All parents completed the questionnaire's general sections, both in the pretest and in the posttest after a year. In the pretest, parents have been asked to answer all questions 
in the questionnaire's specific sections, in the posttest parents only answered questions regarding the program they participated in. Data have been acquired from January 1988 to February 1991. This chapter also discusses the designs and statistical analyses used in the study.

In chapter 7 results are presented conceming the study's theoretical objectives: which variables in the respective basic, coping and social-support models account for the variance in the parents' psychological and physical well-being? In exploring the first, basic stress model. multiple discriminant analyses have shown that the twelve handicapped children's potentially stressful characteristics studied can be reduced to four actually stressful characterictics. It is found that the child's extemalizing behavior problems, limitations in social functioning, limited social and self-care skills and poor physical health aggravate their parents' problems. Furthermore, multiple regression analyses have shown that overall parental well-being is directly determined by one specific parent problem, namely family disruption, low parental self-esteem and a low level of education. Finally, the mentally retarded children's extemalizing behavior problems and limitations in social functioning have been found to affect their parents' well-being indirectly by their feelings of family disruption.

The second model analysed in this chapter explores five coping styles: depressive reactions, seeking social support, palliatives, avoidance and expression of emotions. Adding the five coping styles to the basic model's determinants is found to account for a statistically significant extra proportion of the variance explained in parental well-being. This coping effect can be ascribed entirely to one of the coping styles: depressive reactions. This coping style is shown to have a negative main effect on parental overall well-being. A depressive copingstyle also functions as a mediator between parental family disruption and low self-esteem on the one hand and psychological and physical complaints on the other.

In the third model six social support indices are explored: marital status, support from spouse, number of supportive persons, religious orientation, support from religious orientation and social isolation. Analyses of this social-support model indicate that adding these indices to the basic model's determinants accounts for a significant extra proportion in the variance explained in parental overall well-being. This effect of social support is entirely explained by the variable "social isolation". This variable is found to have a main effect on parental psychological and physical well-being and, in addition, feeling socially isolated mediates between family disruption and a low educational level on the one hand and psychosomatic complaints on the other. Contrary to predictions based on Lazarus" theoretical views on stress, no moderating effects of coping and social support are found.

In chapters 8 and 9 the programs' evaluation results are presented. Data in chapter 8 indicate as hypothesized that parents who apply for the practical pedagogical family support programs (PPG) have more problems and psychosomatic complaints than control group parents. These PPG-group strains can be ascribed to the general 
determinants of parental stress, which means they are ultimately due to the mentally retarded children's extemalizing behavior problems. Reasons why parents apply for the pedagogical family support services include leaming to handle the mentally retarded child's behavior problems, learning to stimulate the child's mental and physical development, to improve family relations and to improve the handicapped child's sociall skills.

Results further suggest that parents who apply for the in-home respite care programs under study (PT) have a higher level of formal education and experience more practical problems than control group parents, as hypothesized. Their mentally retarded child is found lacking in social and self-care skills. Parents applying for these programs usually do so hoping to find a reliable baby-sitter for the handicapped child and hoping to find assistance regarding the child's recreational activities. Finally, results show that parents applying for the out-of-home weekend programs (WO) experience more family disruption and practical problems and are more concerned about their other children's development than control group parents. Since both groups do not appear to differ in the general determinants of parental stress, results do not indicate that WO-group parents have more psychosomatic complaints than control group parents. Parents apply for the out-of-home weekend programs partly for reasons which are in accordance with the programs' aims, i.e to support them and their other children, partly for other reasons, among which hoping to alleviate the handicapped child's (anticipated) loneliness in the home situation figures predominantly.

Chapter 9 focuses upon the programs' effects and the parents' opinions on the services received. Analyses reveal that the practical pedagogical family support services (PPG) considerably improve the mentally retarded children's social functioning and social and self-care skills. Contrary to predictions some other improvements can not be ascribed unequivocally to the programs, for instance the improvements in the handicapped children's behavior, the parents' self-esteem, social isolation, problems and psychological and physical well-being. Parents applying for the pedagogical programs in order to learn to handle their handicapped child's behavior problems and parents hoping to learn to stimulate his or her development, seem to profit more from the programs than parents who participated for other reasons. In general, parents' opinions about the programs are found to be very positive.

Data further indicate that the in-home respite care programs (PT) enhance parental self-esteem. Contrary to the hypothesis, the programs are not found to reduce the parents' practical problems. Parents' opinions on the programs range from moderately to very positive. No effects have been revealed by the out-of-home weekend programs (WO) on parental stress and its determinants. Contrary to hypotheses the improvements in family relations reported can not be ascribed unambiguously to the programs. Parents who applied for the out-of-home weekend programs in order to be supported as a family appear to be more satisfied by the services delivered than parents who applied in order to alleviate their handicapped child's loneliness. 
In chapter 10 the major outcomes of the study are reviewed. Considering the study's theoretical objectives, it is suggested that a content analysis of the entire coping domain, resulting in a classification scheme and a measurement device, might stimulate further research in this domain, thus clarifying the processes underlying the influence of coping on adaptational outcomes of stress processes. Moreover, researchers might do more justice to Lazarus' fundamental contribution to the stress field in formulating more complex coping and social support models in which variables would be treated as if they were causally linked and analysed accordingly. Considering the programs' evaluation results, some preliminary reasoning is proposed in an attempt to find explanations for the unsatisfactory results regarding the effects of the family support programs on parental stress and its determinants. Finally, recommandations are presented to improve future evaluations of family support programs and to improve the programs" contents. 



\section{LITERATUUR}

Arrindell, W.A. \& Ettema, H. (1981). Dimensionele structuur, betrouwbaarheid en validiteit van de Nederlandse bewerking wan de Symptom Checklist (SCL-90); gegevens gebaseerd op een fobische en een "normale" populatie. Nederlands Tijdschrift voor de Psychologie, 36, 77-108.

Bandura, A. (1977). Self-efficacy: Toward a unifying theory of behavioral change. Psychological Review, 84, 191-215.

Bandura, A. (1986). Social foundations of thought and action. A social cognitive theory. Englewood Cliffs: Prentice-Hall Inc.

Baron, R.M. \& Kenny, D.A. (1986). The moderator-mediator variable distinction in social psychological research: Conceptual, strategic and statistical considerations. Journal of Personality and Social Psychology, 51, 1173-1182.

Beckman, P.J. (1983). Influence of selected child characteristics on stress in families of handicapped infants. American Journal of Mental Deficiency. 88, 150-156.

Beerens, P.J.M. (1990). Enkele cijfers over VTO-samenwerking in Nederland. VTO-Nieuwsbrief, 7(1), 7-8.

Bij de Vaate, J. (1986). De centrale overheid. In N.F. van Manen, C.A. de Jong, I.M. Gunters, J. bij de Vaate \& C. Weber (Reds.), Vademecum zorg voor geestelijk gehandicapten (pp. A3110-1 - A3110-30). Alphen aan de Rijn/ Brussel: Samson Stafleu.

Billings, A.G. \& Moos, R.H. (1984). Coping, stress, and social resources among adults with unipolar depression. Journal of Personality and Social Psychology, $46,877-891$.

Blacher, J., Nihira, K. \& Meyers, C.E. (1987). Characteristics of home environment of families with retarded children: Comparison across levels of retardation. American Journal of Mental Deficiency, 91, 313-320.

BOEGG. (1990). Rapportage begeleidingscommissie onderzoek en experiment nieuwe verstrekkingensystematiek voor geestelijk gehandicapten. Amstelveen.

Bontje, L. \& Van der Post, M. (1989). Extra zorg in beeld: De invloed van een geestelijk gehandikapt kind op een aantal aspekten van het gezinsfunctioneren. Utrecht: Rijks Universiteit Utrecht, doctoraalscriptie Orthopedagogiek.

Bos, J.M. (1977). Het gezin met een hartekind. Amsterdam/Lisse: Swets \& Zeitlinger B.V.

Bradshaw, J. \& Lawton, D. (1978). Tracing the causes of stress in families with handicapped children. British Journal of Social Work, 8, 181-192.

Burks, N. \& Martin, B. (1985). Everyday problems and life change events: Ongoing versus acute sources of stress. Journal of Human Stress, 11, 27-35.

Buunk, B. \& Janssen, P. (1991). Sociale vergelijking en omgaan met tegenslagen in de beroepsloopbaan. Gedrag en Gezondheid, 19, 1-11. 
Byme, E.A. \& Cunningham, C.C. (1985). The effects of mentally handicapped children on families: A conceptual review. Journal of Child Psychology and Psychiatry and Allied Disciplines, 26, 847-864.

Centrale Raad van Gezinsverzorging. (1988). Het inclusief beleid binnen de gezinsverzorging. Driebergen.

Choi, T., Josten, L.V. \& Christensen, M.L. (1983). Health-Specific Family Coping Index for Noninstitutional Care. American Journal of Public Health, $73,1275-1277$.

Cobb, S. (1976). Social support as a moderator of life stress. Psychosomatic Medecine, 38, 300-314.

Cobb, S. (1982). Social support and health through the life course. In H.I. MoCubbin, A.E. Cauble \& J.M. Patterson (Eds.), Family stress, coping and social support (pp. 189-199). Springfield, LL: Charles C. Thomas Publisher.

Cohen, S. \& Wills, T.A. (1985). Stress, social support, and the buffering hypothesis. Psychological Bulletin, 98, 310-357.

Commissie Structuur en Financiering Gezondheidszorg. (1987). Bereidheid tot verandering. Den Haag.

Cook, T.D. \& Campbell, D.T. (1979). Quasi-Experimentation. Boston: Houghton Mifflin Company.

Cox, T. (1978). Stress. Houndmills: MacMillan Education Ltd.

Coyne, J.C. \& Lazarus, R.S. (1981). Cognitive style, stress perception and coping. In I.L. Kutash \& L.B. Schlesinger (Eds.), Handbook on stress and anxiety (pp. 144-158). San Fransisco: Jossey-Bass Publishers.

Cmic, K.A., Friedrich, W.N. \& Greenberg, M.T. (1983). Adaptation of families with mentally retarded children: A model of stress, coping and family ecology. American Journal of Mental Deficiency, 88, 125-138.

Cummings, S.T. (1976). The impact of the child's deficiency on the father: A study of fathers of mentally retarded and of chronically ill children. American Journal of Orthopsychiatry, 46, 246-255.

Cummings, S.T., Bayley, H.C. \& Rie, H.E. (1966). Effects of the child's deficiency on the mother: A study of mothers of mentally retarded, chronically ill and neurotic children. American Journal of Orthopsychiatry, 36, 595-608.

De Goede, A. (1991). Praktisch Pedagogische Thuishulp. In H. Baartman (Red.), Praktisch-pedagogische thuishulp in bewerkelijke gezinnen (pp. 56-70). Houten/Antwerpen: Bohn Stafleu Van Loghum.

Delfgauw, J. (1991). Regionaliseren hoeft niet meer zo nodig van Simons. Klik, 20(4), 3-5.

Denis, R. \& Van den Borne, H.W. (1989). Een nieuwe verstrekkingensystematiek voor geestelijk gehandicapten. Tilburg: IVA, Instituut voor Sociaal-Wetenschappelijk Onderzoek van de Katholieke Universiteit Brabant.

Denis, R. \& Van den Borne, H.W. (1990). Zorg op maat in de regio. Tilburg: IVA, Instituut voor Sociaal-Wetenschappelijk Onderzoek van de Katholieke Universiteit Brabant.

De Ruijter, P.A. (1978). Hulpverlener: Deskundige vriend of vriendelijke deskundige. In Mij 'n zorg: Begeleiding van gezinnen met een zwakzinnig kind (pp. 5-8). Amersfoort: De Horstink, DIC-map. 
Dijkstra, P. (1973). Een vergelijking van de zelfbeoordelingsschaal voor depressie van Zung en de D-schaal van de MMPI in een poliklinische setting. In A.P. Cassee, P.E. Boeke \& J.T. Barendregt (Reds.), Ktinische psychologie in Nederland (Deel 2, pp. 9-29). Deventer: Van Loghum Slaterus.

Dijkstra, P. (1974). De zelfbeoordelingsschaal voor depressie van Zung. In H.M. van Praag \& H.G.M. Rooymans (Reds.), Stemming en ontstemming. Theorie en praktijk bij de diagnostiek en de behandeling van depressies (pp. 98120). Amsterdam: De Erven Bohn B.V.

Dirken, J.M. (1969). Arbeid en stress. Groningen: Wolters-Nordhoff N.V.

Dohrenwend, B.S., Dohrenwend, B.P., Dodson, M. \& Shrout, P.E. (1984). Symptoms, hassles, social supports, and life events: Problem of confounded measures. Journal of Abnomal Psychology, 93, 222-230.

Donovan, A.M. (1988). Family stress and ways of coping with adolescents who have handicaps: Matemal perceptions. American Journal on Mental Retardation, 92, 502-509.

Dunkel-Schetter, C., Folkman, S. \& Lazarus, R.S. (1987). Correllates of social support receipt. Journal of Personality and Social Psychology, 53, 71-80.

Erickson, M.T. (1969). MMPI profiles of parents of young retarded children. American Journal of Mental Deficiency, 73, 728-732.

Federatie van Ouderverenigingen. (1980). Gezinsbegeleiding: Een nieuwe wijze van helpen. Bussum.

Federatie van Ouderverenigingen. (1987). Van hulpvraag naar hulpantwoord. Utrecht.

Federatie van Ouderverenigingen. (1989). Mensen met mogelijkheden. Een visie op mensen met een geestelijke handicap. Utrecht.

Federatie van Ouderverenigingen. (1990a). Gezin en logée: Een inventarisatie van gezinnen die deelnemen aan het experiment logeerhuizen. Utrecht.

Federatie van Ouderverenigingen. (1990b). Invoeringsproject Vroegtijdige Opvoedingshulp (=Early Intervention). Utrecht.

Feij, J.A., Van Kampen, J., Doom, C.D., Resing, W.C.M. \& Van den Berg, P.T. (1990). De relatie tussen ingrijpende gebeurtenissen, coping-stijlen en klachten. Gedrag en Gezondheid, 18, 182-196.

Folkman, S. (1984). Personal control and stress and coping processes: A theoretical analysis. Journal of Personality and Social Psychology, 46, 839-825.

Folkman, S. \& Lazarus, R.S. (1980). An analysis of coping in a middle-aged community sample. Journal of Health and Social Behavior, 21, 219-239.

Folkman, S. \& Lazarus, R.S. (1986). Stress processes and depressive symptomatology. Journal of Abnormal Psychology, 95, 107-113.

Folkman, S. \& Lazarus, R.S. (1988). Coping as a mediator of emotion. Journal of Personality and Social Psychology, 54, 466-475.

Folkman, S., Lazarus, R.S., Gruen, R.J. \& DeLongis, A. (1986). Appraisal, coping, health status, and psychological symptoms. Journal of Personality and Social Psychology, 50, 571-579.

Folkman, S., Lazarus, R.S., Dunkel-Schetter, C., DeLongis, A. \& Gruen, R.J. (1986). Dynamics of a stressful encounter: Cognitive appraisal, coping, and 
encounter outcomes. Journal of Personality and Social Psychology, 50, 9921003.

Folkman, S., Schaefer, C. \& Lazarus, R.S. (1979). Cognitive processes as mediators of stress and coping. In V. Hamilton \& D.W. Warburton (Eds.), Human stress and cognition (pp. 265-298). New York: John Wiley.

Fotheringham, J.B. \& Creal, D. (1974). Handicapped children and handicapped families. International Review of Education, 20, 355-373.

Friedrich, W.N. (1979). Predictors of the coping behavior of mothers of handicapped children. Journal of Consulting and Clinical Psychology, 47, 11401141.

Friedrich, W.N., Greenberg, M.T. \& Cmic, K. (1983). A short form of the Questionnaire on Resources and Stress. American Journal of Mental Deficiency, $88,41-48$.

Friedrich, W.N., Wiltumer, L.T. \& Cohen, D.S. (1985). Coping resources and parenting mentally retarded children. American Journal of Mental Deficiency. 90, 130-139.

Gallagher, J.J., Beckman, P. \& Cross, A.H. (1983). Families of handicapped children: Sources of stress and its amelioration. Exceptional Children, 50, 1019.

Gath, A: (1977). The impact of an abnormal child upon the parents. British Journal of Psychiatry, 130, 405-410.

Geestelijk gehandicapten. Tweede Kamer, 1982-1983, 17900, nrs. 1-2.

Gezondheidszorg. Tweede Kamer, 1973-1974, 13012, nrs. 1-2.

Gleser, G. \& Ihilevich, D. (1969). An objective instrument for measuring defense mechanismes. Journal of Consulting and Clinical Psychology, 33, 51-60.

Gresnigt, H.A.A. \& Gresnigt-Strengers, A.M.C. (1973). Ouders en gezinnen met een diep zwakzinnig kind. Amsterdam: Swets \& Zeitlinger B.V.

Grossman, H. (Red.). (1973). Manual on terminalogy and classification in mental retardation (rev. ed.). Washington, DC: American Association on Mental Deficiency.

Gunters, I.M. (1985). Het kinderdagverblijf. In N.F. van Manen, C.A. de Jong, I.M. Gunters, J. bij de Vaate \& C. Weber (Reds.), Vademecum zorg voor geestelijk gehandicapten (pp. A1520-1 - A1520-65). Alphen aan de Rijn/Brussel: Samson Stafleu.

Gunters, I.M. \& De Jong, C.A. (1987). Het dagverblijf voor oudere geestelijk gehandicapten (DVO). In N.F. van Manen, C.A. de Jong, I.M. Gunters, J. bij de Vaate \& C. Weber (Reds.), Vademecum zorg voor geestelijk gehandicapten (pp. A1550-1 - A1550-26). Alphen aan de Rijn/Brussel: Samson Stafleu.

Halfens, R.J.G. (1985). Locus of control. Maastricht: Academisch Proefschrift Rijks Universiteit Limburg.

Helbing, J.C. (1982). Zelfwaardering: Meting en validiteit. Nederlands Tijdschrift voor de Psychologie, 37, 257-277.

Holmes, T.H. \& Masuda, M. (1974). Life change and illness susceptibility. In B.S. Dohrenwend \& B.P. Dohrenwend (Eds.), Stressful life events: Their nature and effects (pp, 45-72). New York: John Wiley \& Sons. 
Holmes, T.H. \& Rahe, R.H. (1967). The Social Readjustment Rating Scale. Journal of Psychosomatic Research, 11, 213-218.

Holroyd, J. (1974). The Questionnaire on Resources and Stress: An instrument to measure family response to a handicapped family member. Journal of Community Psychology, 2, 92-94.

Holroyd, J., Brown, N., Wikler, L. \& Simmons, J.Q. (1975). Stress in families of institutionalized and non-institutionalized autistic children. Journal of Community Psychology, 3, 26-31.

Holroyd, J. \& Guthrie, D. (1979). Stress in families of children with neuromuscular disease. Journal of Clinical Psychology, 35, 734-739.

Holroyd, J. \& McArthur, D. (1976). Mental retardation and stress on the parents: A contrast between Down's syndrome and childhood autisme. American Journal of Mental Deficiency, 80, 431-436.

Hulpverlening aan gezinnen met een gehandicapt kind (Eindnota Motie 19). Tweede Kamer, 1982-1983, 17899, nrs. 1-2.

Instituut voor Toegepaste Sociologie. (1975). Beroepenklapper ( $\left.3^{\circ} \mathrm{druk}\right)$. Nijmegen: ITS.

Janssen, C.G.C. (1982). Ouders van geestelijk gehandicapte kinderen. Naar een vollediger gezinsonderzoek. Lisse: Swets \& Zeitlinger B.V.

Janssen, C.G.C. \& Meester, S.R. (1985). Analyse van factoren die samenhangen met de grenzen van hometraining. Tijdschrifi voor Orthopedagogiek, 24, 508521 .

Jones, W.H. (1985). The psychology of loneliness: Some personality issues in the study of social support. In I.G. Sarason \& B.R. Sarason (Eds.), Social support: Theory, research and applications (pp. 225-241). Dordrecht: Martinus Nijhoff Publishers.

Kanner, A.D., Coyne, J.C., Schaefer, C. \& Lazarus, R.S. (1981). Comparison of two modes of stress measurement: Daily hassles and uplifts versus major life events. Journal of Behavioral Medecine, 4, 1-39.

Kiers, J. (1977). Maatschappelijk werkers: "We hebben te weinig armen en die armen zijn ook nog te kort". Klik, 6(7), 4-7.

Kingma, T. (1984). Zorg voor geestelijk gehandicapten. Ontwikkelingen in de hulpverlening en voorzieningen ( $2^{\circ}$ herz. druk). Alphen aan de Rijn/Brussel: Samson Stafleu.

Kobasa, S.C. (1979). Stressful life events, personality and health: An inquiry into hardiness. Journal of Personality and Social Psychology, 37, 1-11.

Korn, S.J., Chess, S. \& Fernandez, P. (1978). The impact of children's physical handicaps on marital quality and family interaction. In R.M. Lerner \& G.B. Spanier (Eds.), Child influences on marital and family interaction. A lifespan perspective (pp. 299-326). New York: Academic Press.

Koster van Groos, G.A.S. (1989). Beknopte handleiding bij de diagnostische criteria van de $D S M-I I I-R$ ( $3^{\circ}$ druk). Amsterdam: Swets \& Zeitlinger.

Kraijer, D.W. (1988). Intelligentieonderzoek en sociale redzaamheidsbepaling bij zwakzinnigen. Elkaar uitsluitend of juist aanvullend? Ruit, 14(53), 11-20.

Kraijer, D.W. \& Kema, G.N. (1972). Handleiding voor de SRZ, Sociale Redzaamheidsschaal voor Zwakzinnigen. Amsterdam: Swets \& Zeitlinger. 
Kraijer, D.W. Kema, G.N. (1977). Handleiding Sociale Redzaamheidsschaal Storend Gedragsschaal voor Zwakzinnigen, SRZ/SGZ. Amsterdam: Swets \& Zeitlinger.

Krol, A.T.J. (1990). Samenvattend: Beter en concreter. In Stichting J.J. Dondorpfonds, Thuiszorg: Beter en concreter (pp. 53-61). Zutphen: Thieme.

Kuipers, H.P. \& Van der Velden, J.M.H. (1986). VTO als voorportaall van de zorgverlening. In N.F. van Manen, C.A. de Jong, L.M. Gunters, J. bij de Vaate \& C. Weber (Reds.), Vademecum zorg voor geestelijk gehandicapten (pp. A1140-1 - A1140-18). Alphen aan de Rijn/Brussel: Samson Stafleu.

Landelijke Commissie Gezinsbegeleiding. (1982). Eindrapport. Stichting Nationaal Orgaan $Z$ wakzinnigenzorg/Federatie van Ouderverenigingen.

Last, B.F. (1986). Copingstrategieën en gevoelens van welbevinden bij ouders van kinderen met kanker. In P.J.G. Schreurs \& R. Rombouts (Reds.), Omgaan met ernstige ziekten (pp. 27-46). Lisse: Swets \& Zeitlinger.

Lazarus, R.S., Averill, J.R. \& Opton, E.M. (1970). Towards a cognitive theory of emotions. In M.B. Amold (Ed.), Feelings and emotions (pp. 207-232). New York: Academic Press.

Lazarus, R.S., Averill, J.R. \& Opton, E.M. (1974). The psychology of coping: Issues of research and assessment. In G.V. Coelho, D.A. Hamburg \& J.E. Adams (Eds.), Coping and adaptation (pp. 249-315). New York: Basic Books; Inc., Publishers.

Lazarus, R.S. \& Folkman, S. (1984). Stress, appraisal and coping. New York: Springer Publishing Company.

Lazarus, R.S. \& Folkman, S. (1987). Transactional theory and research on emotions and coping. European Journal of Personality, 1, 141-169.

Lazarus, R.S., Kanner, A. \& Folkman, S. (1980). Emotions: A cognitivephenomenological analysis. In R. Plutchik \& H. Kellerman (Eds.), Theories of emotion (Vol. I, pp. 189-217). New York: Academic Press.

Lazarus, R.S. \& Launier, R. (1978). Transactions between person and environment. In L.A. Pervin \& M. Lewis (Eds.), Perspectives in interactional psychology (pp. 287-327). New York: Plenum Press.

Linssen-Musters, S. (1988). Een beschrijwend onderzoek naar de redenen van stagnatie van PPG in de gezinnen van het PPG project Tilburg. Moergestel: Vrije Universiteit Amsterdam, doctoraalscriptie Ontwikkelingspsychologie, Pedologie en Speciale Pedagogiek.

Lonsdale, G. (1978). Family life with a handicapped child: The parents speak. Child: Care, Health and Development, 4, 99-120.

Luteijn, F. \& Kingma, L. (1979): Een nieuwe verkorte MMPI. Nederlands Tijdschrift voor de Psychologie, 34, 459-471.

Luteijn, F., Kok, A.R., Hamel, L.F. \& Poiesz, A. (1979). Enige ervaringen met een klachtenlijst (HSCL). Nederlands Tijdschrift voor de Psychologie, 34, 167-179.

Luteijn, F. Starren, J. \& Van Dijk, H. (1985). Nederlandse Persoonlijkheids Vragenlijst: Handleiding (herz. uitgave). Lisse: Swets \& Zeitlinger, b.v.

Maan, W. (1991). Het invoeringsproject Vroegtijdige Opvoedingshulp/Early Intervention. SOMMA-Informatief, $1 /(1)$, 5-8. 
Marcus, L.M. (1977). Pattems of coping in families of psychotic children. American Journal of Orthopsychiarry, 47, 388-399.

Mason, J.W. (1975a). A historical review of the stress field. Joumal of Human Stress, $1(1), 6-12$.

Mason, J.W. (1975b). A historical review of the stress field. Journal of Human Stress, I(2), 22-36.

McAndrew, I. (1976). Children with a handicap and their families. Child: Care. Health and Development, 2, 213-237.

McCrae, R.R. (1984). Situational determinants of coping responses: Loss, threat, and challenge. Journal of Personality and Social Psychology, 46, 919-928.

McCrae, R.R. \& Costa, P.T. (1986). Personality, coping, and coping effectiveness in an adult sample. Journal of Personality, 54, 385-405.

McCubbin, H.I. (1979). Integrating coping behavior in family stress theory. Journal of Marriage and the Family, 41, 237-244.

McCubbin, H.I., McCubbin, M.A., Patterson, J.M., Cauble, A.E., Willson, L.R. \& Warwick, W. (1983). CHIP-Coping Health Inventory for Parents: An assessment of parental coping patterns in the care of the chronically ill child. Journal of Marriage and the Family, 45, 359-370.

McCubbin, H.I., Nevin, R.S., Cauble, A.E., Larsen, A., Comeau, J.K. \& Patterson, J.M. (1982). Family coping with chronic illness: The case of cerebral palsy. In H.I. McCubbin, A.E. Cauble \& J.M. Patterson (Eds.), Family stress. coping and social support (pp. 169-188). Springfield, IL: Charles C. Thomas Publisher.

Meadow, K.P. \& Meadow, L. (1971). Changing role perceptions for parents of handicapped children. Exceptional Children, 38, 21-27.

Meiresonne, J.B. (Red). (1978). Gezinsbegeleiding: Verslag van een conferentie. Utrecht.

Menaghan, E. (1983). Individual coping efforts: Moderators of the relationship between life stress and mental health outcomes. In H.B. Kaplan (Ed.), Psychosocial stress. Trends in theory and research (pp. 157-191). New York: Academic Press.

Mij ' $n$ zorg. Begeleiding van gezinnen met een zwakzinnig kind. (1978). Amersfoort: De Horstink, DIC-map.

Miller, W.H. \& Keim, W.C. (1978). Personality measurement in parents of retarded and emotionally disturbed children: A replication. Journal of Clinical Psychology, 34, 686-690.

Motie 19. Tweede Kamer, 1977-1978, 14406, nr. 19.

Myers, J.K., Lindenthal, J.J. \& Pepper, M.P. (1974), Social class, life events, and psychiatric symptoms: A longitudinal study. In B.S. Dohrenwend \& B.P. Dohrenwend (Eds.), Stressful life events: Their nature and effects (pp. 191205). New York: John Wiley \& Sons.

Nass, G. (1989). Elf prikkelende initiatieven: Thuishulp aan mensen met een handicap en hun huisgenoten. Utrecht: Stichting Dienstverleners Gehandicapten. 
Nationale Invoering van Praktische Thuishulp in de Eerste Lijn, NIPTEL. (1987). Een paar extra handen: Informatie over praktische thuishulp ( $3^{\circ}$ herz. druk). Utrecht: Stichting Dienstverleners Gehandicapten.

Nationale Raad voor de Volksgezondheid/Nationale Raad voor Maatschappelijk Welzijn. (1986). Interimrapportage zorg- en dienstverlening aan geestelijk gehandicapten. Zoetermeer: NRV/NRMW 4077-73.

Nationale Raad voor de Volksgezondheid/Nationale Raad voor Maatschappelijk Welzijn. (1987). Advies afstemming vraag en aanbod zorg geestelijk gehandicapten: Zoetermeer: NRV/NRMW 4077-130.

Nationale Raad voor de Volksgezondheid/Nationale Raad voor Maatschappelijk Welzijn. (1988). Advies licht geestelijk gehandicapten. Zoetermeer: NRV/NRMW 4077-140.

Noorda, W.K. (1985). Definities van zwakzinnigheid en groepen zwakzinnigen; Classificatiesystemen. In G.H. van Gemert, W.K. Noorda, J. Euwema \& H. Feijen (Reds.), Leerboek zwakzinnigenzorg (pp. 15-22). Assen/Maastricht: Van Gorcum.

Olhansky, S. (1969). Chronic sorrow: A response to having a mentally defective child. In W. Wolfensberger \& R.A. Kurtz (Eds.), Management of the family of the mentally retarded (pp. 116-119). New York: Follet Education Corporation.

Oosterhof-Beugelink, C. (1984). Hometraining: Een pedagagische vorm van hulpverlening aan gezinnen met een geestelijk gehandicapt kind. Groningen: Wolters-Noordhoff, Orthovisies 21.

Oosterhof-Beugelink, C. (1985). Het pedagogische karakter van hometraining: Een terechte aanspraak of een loze pretentie? Tijdschrift voor Orthopedagogiek, 24, 458-475.

Orr, R.R., Cameron, S.J. \& Day, D.M. (1991). Coping with stress in families with children who have mental retardation: An evaluation of the double ABCX Model. American Journal on Mental Retardation, 95, 444-450.

Paunonen, S.V. \& Jackson, D.N. (1988). Type I error rates for moderated multiple regression analysis. Journal of Applied Psychology, 73, 569-573.

Pearlin, L.I., Lieberman, M.A., Meneghan, E.G. \& Mullan, J.T. (1981). The stress process. Journal of Health and Social Behavior, 22, 337-356.

Pearlin, L.I. \& Schooler, C. (1982). The structure of coping. In H.I. McCubbin, A.E. Cauble \& J.M. Patterson (Eds.), Family stress, coping and social support (pp. 109-135). Springfield, IL: Charles C. Thomas Publisher.

Pedhazur, E.J. (1982). Multiple regression in behavioral research (2nd ed.). New York: Holt, Rinehart and Winston.

Peplau, L.A. (1985). Loneliness research: Basic concepts and findings. In I.G. Sarason \& B.R. Sarason (Eds.), Social support: Theory, research and applications (pp. 269-286). Dordrecht: Martinus Nijhoff Publishers.

Plutchik, R., Kellerman, H. \& Conte, H.R. (1979). A structural theory of ego defenses and emotions. In C.E. Izard (Ed.), Emotions in personality and psychopathology (pp. 229-257). New York: Plenum Press.

Rahe, R.H. \& Arthur, R.J. (1978). Life change and illness studies: Past history and future directions. Journal of Human Stress, 4, 3-15. 
Rippetoe, P.A. \& Rogers, R.W. (1987). Effects of components of the protectionmotivation theory on adaptive and maladaptive coping with a health threat. Journal of Personality and Social Psychology, 52, 596-604.

Rosenberg, M. (1965). Society and the adolescent self-image. Princeton, NJ: Princeton University Press.

Rotter, J.B. (1975). Some problems and misconceptions related to the construct of intemal versus extemal control of reinforcement. Journal of Consulting and Clinical Psychology, 43(1), 56-67.

Sanderman, R. \& Ormel, J. (1992). De Utrechtse Coping Lijst (UCL): Validiteit en betrouwbaarheid. Gedrag en Gezondheid, 20, 32-37.

Sarason, I.G. \& Sarason, B.R. (Eds.). (1985). Social support: Theory, measurement and applications. Dordrecht: Martinus Nijhoff Publishers.

Schaefer, C., Coyne, J.C. \& Lazarus, R.S. (1981). The health-related functions of social support. Journal of Behavioral Medecine, 4, 381-406.

Schaufeli, W. \& Van Dierendonck, D. (1992). De betrouwbaarheid en validiteit van de Utrechtse Coping Lijst. Gedrag en Gezondheid, 20, 38-45.

Schreurs, P.J.G., Tellegen, B. \& Van de Willige, G. (1984). Coping-Lijst. Gedrag-tijdschrift voor Psychalogie, 12(1/2), 101-117.

Schreurs, P.J.G., Van de Willige, G., Tellegen, B. \& Brosschot, J.F. (1988). De Utrechtse Coping Lijst: UCL-Handleiding. Lisse: Swets \& Zeitlinger.

Seidman, E. \& Rapkin, B. (1983). Economics and psychosocial dysfunctioning: Toward a conceptual framework and prevention strategies. In R.D. Felner, L.A. Jason, J.N. Moritsugu \& S.S. Farber (Eds.), Preventive psychology. Theory, research and practice (pp. 175-198). New York: Pergamon Press.

Selye, H. (1956). The stress of life. New York: McGraw-Hill Book Company, Inc.

Selye, H. (1978). Stress. Utrecht/Antwerpen: Uitgeverij Het Spectrum.

Shapiro, J. (1983). Family reactions and coping strategies in response to the physically ill or handicapped child: A review. Social Science and Medecine. $17,913-931$.

SOMMA. (1986). Praktisch Pedagogische Gezinsbegeleiding: Organisatie en praktijk. Zeist.

SOMMA. (1990a). Getallen geteld: Cliëntenregistratiegegevens van de Sociaal Pedagogische Dienst. Utrecht.

SOMMA. (1990b). Handreiking voor indicatiestelling bij PPG. Utrecht.

Stichting Nederlandse Gehandicaptenraad. (1986). Thuishulp aan mensen met een handicap. Utrecht.

Strickland, B.R. (1978). Internal-external expectancies and health-related behavior. Journal of Consulting and Clinical Psychology, 46, 1192-1211.

Suls, J. (1982). Social support, interpersonal relations, and health: Benefits and liabilities. In G.N. Sanders \& J. Suls (Eds.), Social psychology of health and illness (pp. 255-277). Hillsdale, NJ: Lawrence Earlbaum Associates, Inc., Publishers.

Suurmeijer, T.P.B.M. (1980). Kinderen met epilepsie. Groningen: Academisch Proefschrift Rijks Universiteit Groningen. 
Syme, S.L. \& Berkman, L.F. (1976). Social class, susceptibility and sickness. American Journal of Epidemiology, 104, 1-8.

Tellegen, B. \& Winnubst, J.A.M. (1986). Aspecten van coping: Een analyse. Gedrag en Gezondheid, 14, 114-118.

Ter Horst, W. (1980). Algemene orthopedagogiek: Proeve van een theorieconcept. Kampen: Uitgeversmaatschappij J.H. Kok.

Te Veldhuis, F.H. (1984). Kortverblijf. In N.F. van Manen, C.A. de Jong, I.M. Gunters, J. bij de Vaate \& C. Weber (Reds.), Vademecum zorg voor geestelijk gehandicapten (pp. A1620-1 - A1620-10). Alphen aan de Rijn/Brussel: Samson Stafleu.

Tew, B. \& Laurence, K.M. (1973). Mothers, brothers and sisters of patients with spina bifida. Developmental Medecine and Child Neurology, 15(Supp. 29), 69-76.

Thoits, P.A. (1985). Social support and psychological well-being: Theoretical possibilities. In I.G. Sarason \& B.R. Sarason (Eds.), Social support: Theory, research and applications (pp. 51-72). Dordrecht: Martinus Nijhoff Publishers.

Thoits, P.A. (1986). Social support as coping assistance. Journal of Consulting and Clinical Psychology, 54, 416-423.

Turner, R.J. (1983). Direct, indirect, and moderating effects of social support on psychological distress and associated conditions. In H.B. Kaplan (Ed.), Psychological stress. Trends in theory and research (pp. 105-155). New York: Academic Press.

Uitgangspunten voor een gecoördineerde beleidsontwikkeling ten aanzien van geestelijk gehandicapten. Tweede Kamer, 1980-1981, 16400, hoofdstuk XVIII, nr. 52.

Vaillant, G.E. (1971). Theoretical hierarchy of adaptive ego defense mechanismes. Archives of General Psychiatry, 24, 107-118.

Vaillant, G.E. (1977). Adaption to life. Boston: Little, Brown and Company.

Van Berkum, G. (1986). Weekend-opvang voor geestelijk gehandicapten: Effekten van een zorgvorm. Veldhoven: Severinusstichting.

Van Berkum, H.W., Bremer, J.J.C.B., Kok, G.J. \& Wijffels, J.C.H.M. (1988). Weekendopvang voor geestelijk gehandicapten: Effecten. Ruit, 14(54), 4-17.

Van den Borne, H.W., Denis, R. \& Maas, J.M.A.G. (1988). Op weg naar zorg op maat. Tilburg: IVA, Instituut voor Sociaal-Wetenschappelijk Onderzoek van de Katholieke Universiteit Brabant.

Van der Meulen, B.F. \& Kema, G.N. (1976). Sociale Redzaamheidsschaal voor Kinderdagverblijfbezoekers, SRK. Handleiding en verantwoording. Amsterdam: Swets \& Zeitlinger, b.v.

Van der Meulen, J.J. (1989). Ouderparticipatie. In N.F, van Manen, C.A. de Jong, I.M. Gunters, J. bij de Vaate \& C. Weber (Reds.), Vademecum zorg voor geestelijk gehandicapten (pp. A1205-1 - A1205-24). Alphen aan de Rijn/Brussel: Samson Stafleu.

Van Gemert, G.H. \& Kraijer, D.W. (1985). Intelligentie, ontwikkelingsniveau en cognitie bij zwakzinnigen. In G.H. van Gemert, W.K. Noorda, J. Euwema \& 
H. Feijen (Reds.), Leerboek zwakzinnigenzorg (pp. 98-118). Assen/Maastricht: Van Gorcum.

Van Heck, G.L. \& Vingerhoets, A.J.J.M. (1989). Copingstijlen en persoonlijkheidskenmerken. Nederlands Tijdschrift voor de Psychologie, 44, 73-87.

Van Knippenberg, A. \& Siero, F. (1980). Multivariate analyse. Deventer: Van Loghum Slaterus b.v.

Van Linge, R.H. \& Janssen, C.G.C. (1985). Handelingsproblemen in gezinnen met een geestelijk gehandicapt kind die praktisch pedagogische gezinsbegeleiding ontvangen. Tijdschrift woor Orthopedagogiek, 24, 493-507.

Van Linge, R.H. \& Janssen, C.G.C. (1987). Praktisch Pedagogische Gezinsbegeleiding: Een onderzoek naar de organisatiestructuur en het functioneren. Amsterdam: Vrije Universiteit, sectie Speciale Pedagogiek.

Verbraak, P. (1978). Naar een andere zwakzinnigenzorg ( $2^{\circ}$ druk). Amsterdam/Lisse: Swets \& Zeitlinger B.V.

Verheijen, B. (1984). Hometraining: Poging tot het construeren van een algemeen toepasbaar model. Leiden: Rijks Universiteit Leiden, doctoraalscriptie Klinische- en Orthopedagogiek.

Vingerhoets, A.J.J.M., Jeninga, A.J. \& Menges, L.J. (1989). Het meten van chronische en alledaagse stressoren: Eerste onderzoekservaringen met de Alledaagse Problemen Lijst (APL) II. Gedrag en Gezondheid, 17, 10-17.

Vingerhoets, A.J.J.M. \& Menges, L.J. (1988). Het meten van chronische en alledaagse stressoren: Een literatuuroverzicht I. Gedrag en Gezondheid, 16, 124-130.

Vingerhoets, A.J.J.M. \& Van Heck, G.L. (1990). Gender, coping and psychosomatic symptoms. Psychological Medecine, 20, 125-135.

Vonk-Dekkers, R. \& Verhoeven, M. (1989). Ideeën voor verdere ontwikkeling van Praktisch Pedagogische Gezinsbegeleiding. Tilburg: Katholieke Leergangen, werkstuk Pedagogiek.

Walker, J.H., Thomas, M. \& Russell, I.T. (1971). Spina bifida and the parents. Developmental Medecine and Child Neurology, 13, 462-476.

Wels, P.M.A. \& Robbroeckx, L.M.H. (1991a). Gezinsbelasting en hulpverlening aan gezinnen I: Een model voor gezinsbelasting ten gevolge van een problematische opvoedingssituatie. Tijdschrift voor Orthopedagogiek, 30, 5-19.

Wels, P.M.A. \& Robbroeckx, L.M.H. (1991b). Gezinsbelasting en hulpverlening aan gezinnen II: De constructie van de Nijmeegse Vragenlijst voor de Opvoedingssituatie (NVOS). Tijdschrift voor Orthopedagogiek, 30, 63-79.

Werken aan zorgvernieuwing. Tweede Kamer, 1989-1990, 21545, nrs. 1-2.

Wheaton, B. (1985). Models for the stress-buffering functions of coping resources. Journal of Health and Social Behavior, 26, 352-364.

Wikler, L.M. (1986). Periodic stresses of families of older mentally retarded children: An exploratory study. American Journal of Mental Deficiency, 90 , 703-706.

Wikler, L., Wasow, M. \& Hatfield, E. (1981). Chronic sorrow revisited: Parent vs. professional depiction of the adjustment of parents of mentally retarded children. American Journal of Orthopsychiatry, 51, 63-70. 
Willcox, B.L. \& Vemberg, E.M. (1985). Conceptual and theoretical dilemmas facing social support research. In I.G. Sarason \& B.R. Sarason (Eds.), Social support: Theory, research and applications (pp. 3-20). Dordrecht: Martinus Nijhoff Publishers.

Wilde, G.J.S. (1970). Neurotische labiliteit gemeten volgens de vragenlijstmethode ( $2^{\circ}$ vermeerderde uitgave). Amsterdam: F. van Rossen.

Wills, T.A. \& Langner, T.S. (1981). Socioeconomic status and stress. In I.L. Kutash \& L.B. Schlesinger (Eds.), Handbook on stress and anxiety (pp. 159173). San Fransisco: Jossey-Bass Publishers.

Wishart, M.C., Bidder, R.T. \& Gray, O.P. (1980). Parental responses to their developmentally delayed children and the South Glamorgan Home Advisory Service. Child: Care, Health and Development, 6, 361-376.

Witteveen, F.J.L.M. (1985). Provinciale en regionale overlegorganen zwakzinnigenzorg. In N.F. van Manen, C.A. de Jong, I.M. Gunters, J. bij de Vaate $\&$ C. Weber (Reds.), Vademecum zorg voor geestelijk gehandicapten (pp. A2030-1 - A2030-14). Alphen aan de Rijn/Brussel: Samson Stafleu.

World Health Organization. (1980). International Classification of Impairments. Disabilities, and Handicaps: A manual of classification in relation to the consequences of disease. Genève: WHO.

Wortman, C.B. \& Dunkel-Schetter, C. (1987). Conceptual and methodological issues in the study of social support. In A. Baum \& J.E. Singer (Eds.), Handbook of psychology and health (Vol. V, pp. 63-108). Hillsdale, NJ: Lawrence Earlbaum Associates, Publishers.

Ziekenfondsraad. (1987a). Verstrekkingen geestelijk gehandicapten. Amstelveen: ZR-367.

Ziekenfondsraad. (1987b). Onderzoek nieuw verstrekkingensysteem geestelijk gehandicapten. Amstelveen: ZR-368.

Ziekenfondsraad. (1990a). Subsidiëring experiment nieuwe functiegerichte verstrekkingensystematiek voor geestelijk gehandicapten. Amstelveen: ZR$128 / 71$.

Ziekenfondsraad. (1990b). Cliëntgebonden budget voar de thuishulp. Amstelveen: ZR-470.

Ziekenfondsraad. (1990c). Praktische Thuishulp. Amstelveen: ZR-495.

Zorg - en dienstverlening ten behoeve van geestelijk gehandicapten: Regeringsstandpunt. Tweede Kamer, 1988-1989, 20931, nrs. 2-3.

Zorg - en dienstverlening ten behoeve van geestelijk gehandicapten: Werknotitie zorginnovatie verstandelijk gehandicapte personen. Tweede Kamer, 19901991, 20931, nrs. 17-18.

Zung, W.W.K. (1965). A Self-Rating Depression Scale. Archives of General Psychiatry, 12, 63-70.

Zung, W.W.K., Richards, C.B. \& Short, M.J. (1965). Self-Rating Depression Scale in an outpatient clinic. Archives of General Psychiatry, 13, 508-515. 
Tabel 1

Factorladingen $(\geq 30)$ na varimax rotatie: gedragsprablemen $(n=226)$

\begin{tabular}{|c|c|c|c|c|c|}
\hline \multirow[b]{2}{*}{ Items } & \multicolumn{4}{|c|}{ Factoren } & \\
\hline & 1 & 2 & 3 & 4 & \\
\hline 1. Agressief gedrag & .71 & & & & \\
\hline 2. Schreeuw- en gilbuien & .67 & & & & \\
\hline 3. Destructief gedtrag & .63 & & & & \\
\hline 4. Veel en snel huilen & .60 & & & & \\
\hline 5. Druk en opgewonden gedrag & .53 & .53 & & & \\
\hline 6. Ongehoorzaamheid & .53 & & .32 & & \\
\hline 7. Zelfverwondend gedrag & 50 & & & .38 & \\
\hline 8. Aan je hangen & & .79 & & & \\
\hline 9. Aandacht vragen & 33 & .74 & & & \\
\hline 10. Voortdurend dezelfde vragen stellen & & & .70 & & \\
\hline 11. Eetproblemen & & & .81 & & \\
\hline 12. Slaapproblemen & & & .68 & & \\
\hline 13. In zichzelf gekeerd zijin & & & & .80 & \\
\hline 14. Stereotype bewegingen maken & & & & .76 & \\
\hline Eigenwaarde & 3.56 & 1.78 & 1.29 & 1.21 & \\
\hline Percentage verklaarde variantie & $25.4 \%$ & $12.7 \%$ & $9.2 \%$ & $8.6 \%$ & $56.0 \%$ \\
\hline
\end{tabular}

\section{Tabel 2}

Factorladingen ( $\geq 30)$ na varimax rotatie: sociale redzaamheid $(n=226)$

\section{Factoren}

Items

123

1. Wensen uilien tegenover anderen

.78

2. Behulpzaam zijn 34

3. Voor zichzelf opkomen .68

4. Delen

.68

5. Lenen

.65

6. Wensen uiten tegenover ouders

7. Bewegingavijheid

8. Vriendelijk $z \mathrm{ijn}$

9. Graag met anderen omgaan

10. Gemalkkelijk contact maken

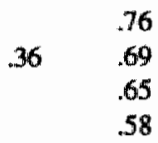

11. Zich goed gedragen in gezelschup

12. Contact met gezinsleden

13. Contact met ouders

Eigenwaarde

Percentage verklaarde variantie

$\begin{array}{cccc}5.00 & 1.68 & 1.12 & \\ 38.5 \% & 13.0 \% & 8.7 \% & 60.1 \%\end{array}$


Tabel 3.1

Intercorrelaties items ten aanzien van de problemen met betrekking tot de partmer $(n=203)$

\begin{tabular}{|c|c|c|c|}
\hline lems & 2 & 3 & 4 \\
\hline 1. Uitgaan mel partuer & $.34 *$ & .09 & $-.24 *$ \\
\hline 2. Voldoende andachit woor partner & - & $.26 *$ & $-21 *$ \\
\hline 3. Goede relatie partner-k $\mathrm{k} . \mathrm{h}$. & & - & -.08 \\
\hline $\begin{array}{l}\text { 4. Partuer heeft dingen opgegeven } \\
\text { inds geboorte kvih. }\end{array}$ & & & - \\
\hline
\end{tabular}

Noot. K.v.h. $=$ kind met een verstandelijke handicap.

*p<.001, een-zijdig.

\section{Tabel 3.2}

Intercorrelaties items ten aanzien van de zorgen over de ontwikkeling van de andere kinderen $(n=175)$

\begin{tabular}{|c|c|c|c|c|c|}
\hline Items & 2 & 3 & 4 & 5 & 6 \\
\hline $\begin{array}{l}\text { 1. Belast andere kinderen } \\
\text { met zorgen over k.v.h. }\end{array}$ & $.36^{* * *}$ & $.39 * * *$ & $.38 * * *$ & $.30 * * *$ & $.38 * * *$ \\
\hline $\begin{array}{l}\text { 2. Onvoldoende aandacht voor } \\
\text { andere kinderen }\end{array}$ & - & $.44 * * *$ & $.15^{*}$ & $.21^{* * *}$ & $.34 * * *$ \\
\hline $\begin{array}{l}\text { 3. K.v.h. verstoort ontwikkeling } \\
\text { andere kinderen }\end{array}$ & & - & $.18^{* *}$ & $.37 * *$ & $42^{* * * *}$ \\
\hline $\begin{array}{l}\text { 4. Mijn andere kinderen springen } \\
\text { te valk bij }\end{array}$ & & & - & $.20 * *$ & $.16 *$ \\
\hline $\begin{array}{l}\text { 5. Mijn andere kinderen worden } \\
\text { in sociale contactem beperkt }\end{array}$ & & & & - & $.27 * * *$ \\
\hline $\begin{array}{l}\text { 6. Mijn andere kinderen moeten } \\
\text { zich thuis inhouden }\end{array}$ & & & & & - \\
\hline
\end{tabular}

Noot. K.v.h.= kind met een verstandelijke handicap.

${ }^{*}$ p<.05, een-zijdig. **p<.01, een-zijdig. ${ }^{* * *} p<.001$, een-zijdig. 
Factorladingen ( $\geq 30$ ) na varimax rotatie: concrete problemen ( $n=226$ )

\section{Factoren}

Items

\begin{tabular}{lll}
\hline 1 & 2 & 3
\end{tabular}

1. Gedrag k.v.h. onverdragglijk voor gezin

2. Spanningen thuis

.83

3. Verzorging aarkunnèn

4. Er niet meer tegen kunnen

5. K.v.h. legt druk op gezin

.72

6. Ongestoord kunnen eten

.66

7. Verantwoordelijkheid voor

$-.58$

k.v.h. kumen dragen

8. Zich kunnen ontspannen

9. Tijd voor eigen bezigheden hebben

$-.56$

10. Dingen opgeven

(1)

11. Zelden de handen vrij hebben

12. Tijd voor huishouding hebben

13. Zich alleen voelen

$\begin{array}{rrr}-.48 & & -.39 \\ & -.74 & \\ & .69 & \\ .31 & .62 & \\ -.41 & -.48 & \\ & & .73 \\ & & -.72 \\ & & .69\end{array}$

14. Geregeld bezoek ontvangen

15. Als gezin op ons zelf staan

Eigenwaarde
Percentage verklaarde variantic

$\begin{array}{lll}5.57 & 1.37 & 1.13\end{array}$

$37.1 \% \quad 9.1 \% \quad 7.5 \% \quad 53.8 \%$

Noot. K.v.h.= kind met een verstandelijke handicap. 
Factoren

\begin{tabular}{|c|c|c|c|c|c|c|}
\hline Items: & 1 & 2 & 3 & 4 & 5 & \\
\hline 1. Zaken somber inzien (D) & .81 & & & & & \\
\hline $\begin{array}{l}\text { 2. Zich door problemen in beslag } \\
\text { laten nemen (D) }\end{array}$ & .79 & & & & & \\
\hline $\begin{array}{l}\text { 3. Denken "na regen komt } \\
\text { zonneschijn" (G) }\end{array}$ & -.65 & .45 & & & & \\
\hline $\begin{array}{l}\text { 4. Verschillende oplossingen } \\
\text { bedenken }(A)\end{array}$ & & .70 & & & & \\
\hline 5. Problemen bespreken (S) & & .69 & & & & \\
\hline 6. Troost zoeken $(\mathrm{S})$ & .49 & .58 & & & & \\
\hline $\begin{array}{l}\text { 7. Denken "anderen hebben het } \\
\text { soms ook moeilijk" }(G)\end{array}$ & & .58 & & .31 & & \\
\hline 8. Er even uit gaan $(P)$ & & & .87 & & & \\
\hline 9. Afleiding zoeken (P) & & & .81 & & & \\
\hline 10. Zaken op hun beloop laten (V) & & & & .80 & & \\
\hline 11. Problemen uit de weg gaan (V) & & & & .62 & & \\
\hline 12. Doelgericht te werk gaan (A) & -.33 & .43 & & -49 & & \\
\hline 13. $\mathbb{K}$ watheid tonen ( $E$ ) & & & & & .84 & \\
\hline 14. Ergernis laten blijken $(\mathrm{E})$ & & & & & .78 & \\
\hline Eigenwaarde & 2.75 & 2.40 & 1.59 & 1.25 & 1.01 & \\
\hline Percentage verklaarde variantie & $19.6 \%$ & $17.2 \%$ & $11.4 \%$ & $9.1 \%$ & $7.0 \%$ & $64.3 \%$ \\
\hline
\end{tabular}

Noot. Tussen haakjes staan de oorspronkelijke subschalen vermeld waartoe de items in de Utrechtse Coping Lijst behoren: (D) depressief reactiepatroon, (G) geruststellende gedachten, (A) actief problemen aanpakken, confronteren, (S) sociale steun zoeken, (P) palliatieve reactie, (V) vermijding, (E) expressie van emoties (Schreurs, Van de Willige, Tellegen \& Brosschot, 1988). 


\section{Tabel 5}

Overzicht van de variabelen in de blokken $1 \mathrm{t} / \mathrm{m}$ 8: scoring, betrowwbaarheid. gemiddelde en standaarddeviatie $(n=181)$

Variabele

Scoring/omscherijving

$\begin{array}{cll}\alpha / t \text { Gemid- Standard- } \\ \text { delde } \\ \text { (M) } & \text { (SD) }\end{array}$

(M) (SD)

Blok 1: Kenmerken werstandelijk gehandicapt kind
1. Geslacht
0 (nieisje)
$-81$
(jongen)
100
2. Verstandelijk niveau
2 (matig)
$-\quad 36$
1,95
59
van functioneren
3 (licht verstandelijk
118
gehandicapt)
3. Lichamelijke gezon
1 (slecht) tot 3 (goed)
27
a. Kan zichzelf niet bezighouden
bïj alle gedrags-
.68
$-\quad 241$
.66
problemen:
b. extravert gedrag
c. aandachtvragend gedrag
1 (weinig) tot 4 (veel)

$-\quad-\quad 2.12$
1.07
d. eell- en slaapproblemen
e. introvert gedrag
5. Sociale redzalamheid:
a. sociale vaardigheden
b. sociale gerichtheid
c. kwaliteit van hef conitact binnen het gezin

4

$.74-1.60-.52$

$.72-1.95 \quad .78$

$.48 \quad-\quad 1.49 \quad .67$

$\begin{array}{lll}.52- & -\quad 1.72 \quad .83\end{array}$
bij alle maten van sociale redzaamheid:

\begin{tabular}{|c|c|c|}
\hline .84 & - & 2.04 \\
\hline .68 & - & 2.54 \\
\hline
\end{tabular}
1. (weinig) tot 3 (sociaal
$.79-2.83$ redraam)
6. Zelfiredzaamheid
1 (meinig) tot 3
(zelfredzaam)

$\begin{array}{lll}.88-2.08 & -72\end{array}$

Blok 1 gereduceerd: Stresserende kenmerken verstandelijk gehandicapt kind

1. Gedragsproblemen

1 (weinig) tot 4 (veel)

.56

-

1.67

48

2. Sociale redzamheid

1 (weinig) tot 3 (sociaal

.55

2.68

.39 redzaam)

3. Sociale varardigheden

1 (weinig) tot 3 (veel)

$.75 \quad-$

2.20 en zelfredzaamheid

4. Lichamelijke gezondheid

1. (slecht) tot 3 (goed)

.68

.66

Blok 2: Kenmerken van de ouders

1. . Sociale klasse

1 (ongeschoolde arbeid)

$-14$

1.60

2 (geschoolde arbeid)

54

3 (lagere employés)

33

4 (kleine zelfistandigen)

17

5 (middelbare employés)

34

6 (hogere beroepen)

23

2. Opleidingsniveau moeder

opleidingsniveau beide

ouders:
1 (lagere school)
2 (lager beroepsonderwijs)
3 (MAVO, (M)ULO)
4 (MBO)

3. Opleidingsniveau vader

5 (HAVO, HBS)

6 (HBO en WO $\mathrm{t} / \mathrm{m}$ kandidaats)

7 (WO t/m doctoraal)

4. Zelfwatardering

1 (weinig) tot 3 (veel)

$.79-2.54$ 


N

$M$

SD

\title{
Blok 3: Kenmerken wan de andere kinderen
}

1. Aantal andere kinderen

\author{
1 tot 8 \\ 1 (jongste) \\ 2 (middelste) \\ 3 (oudste)
}

2. Plaats k.v.h. in de kinderrij

$\begin{array}{cccc}- & - & 1.88 & 1.37 \\ - & 87 & - & - \\ & 26 & & \\ & 68 & & \\ - & - & 262 & .58\end{array}$

3. Relatie k.v.h. met

1 (slechi) tot 3 (goed) broer(s) en/of zus(sen)

Blok 4: Leeftijden van de gezinsleden

1. Leefitijd verstandelijk $16 \mathrm{mmd}-31 \mathrm{jr}$ gehandicapt kind

$\begin{array}{llll}- & - & 10.5 \mathrm{jr} & 6.0 \mathrm{jr} \\ - & - & 39.1 \mathrm{jr} & 8.8 \mathrm{jr} \\ - & - & 40.5 \mathrm{jr} & 8.4 \mathrm{jr} \\ - & - & 11.1 \mathrm{jr} & 7.9 \mathrm{jr}\end{array}$

2. Leeftijd moeder

$26 \mathrm{jr}-65 \mathrm{jr}$

3. Leeftijd vader

$22 \mathrm{jr}-70 \mathrm{jr}$

4. Gemiddelde leeftijd

$1 \mathrm{jr}-34 \mathrm{jr}$ andere kinderen

Blok 5: Concrete probllemen

1. Gezinisverstoring

2. Praktische druk

3. Problemen met betrekking tot de partmer

4. Zorgen over de ontwrikkelling van de andere kinderen

Blok 6: Psychosomatisch 1 (goed) tot 4 (slecht) onwelbevinden

Blok 7: Coping

1. Depressief reactiepatroon

2. Sociale steun zoeken

3. Palliatieve reactie

4. Vermijding

5. Expressie van emoties

Blok 8: Sociale steun

1. Burgerlijke staat

2. Partnersteun

3. Totaal aantal steungevenden

4. Lidmotatschap geloofsgemeenschap

5. Steun uit geloof

6. Sociale isolatie

bij alle concrete problemen:

1 (weinig) tot 3 (veel)

bij alle copingstijlen

1 (weinig) tot 4

(veel gebruikt)

0 (alleenstaand)

0 (geen steun)

1 (steun)

1 tot 4

0 (geen lid)

1 (lid)

1 (geen) tot 3 (veel)

1 (niet) tot 3 (sociaal
.86

$\begin{array}{llll}.68 & - & 1.83 & .71 \\ & & & \\ .57 & - & 2.56 & .66 \\ .74 & - & 1.94 & .77 \\ .50 & - & 1.91 & .64 \\ .59 & - & 2.31 & .78\end{array}$

1 (gehuwd/samenwonend) geisoleerd)
$-1.78 \quad .62$
$-\quad 1.69$

$.51-1.49 \quad .43$

$.71 \quad-\quad 1.31 \quad .40$

$\begin{array}{lll}.80- & - & 1.68\end{array}$

-12
$-\quad 169$

\section{7}

$-42$

$\begin{array}{ccc} & 112 \\ -\quad & - & \\ & & \end{array}$

$\begin{array}{rr}26 & - \\ -\quad 155\end{array}$

$\begin{array}{llll}- & - & 1.42 & .72\end{array}$

$\begin{array}{lll}.38-1.56 & .56\end{array}$

Noot. $\alpha$ geeft een indicatie voor de betrouwbaarheid van een schaal die uit meer dan twee variabelen bestaat, $r$ van een schaal die uit twee variabelen bestaat. $N$ wordt alleen gegeven voor variabelen waarvan de waarden op nominaal of ordinaal nivo liggen. K.v.h.= kind met een verstandelijke handicap. 


\author{
Brief 1 \\ Introductie van het onderzoek: voormeting \\ Begeleidingscommissie \\ t.b.v. onderzoek naar thuiszorg \\ p/a drs. G. van Berkum \\ Postbus 6666 \\ 5500 MA Veldhoven \\ Veldhoven, datum \\ Aan alle ouders en verzorgers \\ die gebruik maken van: \\ Weekendopvang \\ Praktische Thuishulp \\ Praktisch Pedagogische Gezinsbegeleiding \\ Geen van deze hulpvormen
}

Geachte ouders en verzorgers,

Sedert enige jaren bestaan in Nederland een aantal nieuwe vormen van hulp voor ouders van een thuis wonend kind met een verstandelijke handicap of een ontwikkelingsachterstand. Deze hulpvormen proberen ouders en verzorgers ondersteuning te bieden bij de verschillende moeilijkheden die het thuis grootbrengen van deze kinderen met zich brengt.

Naar drie van deze hulpvormen wordt nu onderzoek gedaan. Dit zijn:

(1) De projecten Weekendopvang die in de vakantieboerderij in Veldhoven, het kinderdagverblijf "De Elzengaard" in Den Bosch en het kinderdagverblijf "Het Zonnelicht" in Tilburg georganiseerd worden gedurende enkele weekends per jaar ter ontlasting van het gezin;

(2) De Praktische Thuishulp voor hulp bij problemen van praktische aard, zoals bijvoorbeeld oppas; en

(3) Praktisch Pedagogische Gezinsbegeleiding voor ondersteuning bij moeilijkheden in de opvoeding van en de omgang met het kind.

Het onderzoek richt zich met name op de belasting van ouders en verzorgers van een thuis wonend kind met een verstandelijke handicap of een ontwikkelingsachterstand. De belangrijkste vraag die met het onderzoek beantwoord moet worden, is: Welke effecten hebben de drie hulpvormen op de belasting die deze ouders en verzorgers ervaren? 
Het onderzoek wordt voomamelijk uitgevoerd in de regio Zuidoost-Brabant, terwijl ook verschillende projecten in de regio's Noordoost- en Midden-Brabant eraan meewerken. Het onderzoek staat onder auspiciën van de Vereniging Regionaal Overlegorgaan Zorg voor Geestelijk Gehandicapten Zuidoost-Brabant en wordt uitgevoerd in samenwerking met de Rijks. Universiteit Limburg. Het onderzoek is opgezet door de onderzoekster die in 1986 een studie deed naar het weekendexperiment in Veldhoven, mevrouw drs. G. wan Berkum.

Om de vraagstelling van het onderzoek zo goed mogelijk te kunnen beantwoorden, doen wij een beroep op alle ouders en verzorgers die gebruik maken of willen gaan maken van eén of meer van de drie genoemde hulpvormen, om hun medewerking aan het onderzoek te verlenen. Ook zouden wij het zeer op prijs stellen als ouders en verzorgers die geen gebruik maken van de genoemde hulpvormen, zouden meewerken aan het onderzoek: hun gegevens zijn onontbeerlijk als vergelijkingsmateriaal.

Het onderzoek wordt uitgevoerd met behulp van een uitgebreide vragenlijst die aan alle ouders en verzorgers die meewerken aan het onderzoek, wordt toegestuurd. In de vragenlijst worden vragen gesteld over de drie te onderzoeken vormen van hulp (de projecten Weekendopvang, Praktische Thuishulp en Praktisch Pedagogische Gezinsbegeleiding). Voorts worden vragen gesteld over uw gehandicapte zoon of dochter of uw zoon of dochter met een ontwikkelingsachterstand, over uw eventuele andere kind(eren), over uw eigen gezondheid en over moeilijkheden die u wellicht ervaart nu u een kind met een achterstand heeft. Het invullen van de vragenlijst zal ongeveer éen tot anderhalf uur tijd kosten.

Wij willen u er met nadruk op wijzen dat de antwoorden die u geeft, volstrekt vertrouwelijk worden behandeld. Niemand krijgt inzage in de gegevens die u verstrekt en de vragenlijst wordt vemietigd zodra uw antwoorden zijn verwerkt. Aan het eindverslag zal bovendien een zodanige vorm worden gegeven dat niet is na te gaan welke antwoorden $\mathbf{u}$ of enig andere ouder of verzorger heeft gegeven. Overigens krijgt $u$ een samenvatting van de resultaten als het onderzoek is afgerond.

Wij zouden het zeer waarderen als u uw medewerking aan het onderzoek wilt verlenen. Mevrouw Van Berkum zall binnenkort contact met u opnemen om uw medewerking te vragen. Mocht u vorr die tijd vragen hebben, dan kunt u daarmee bij haar terecht.

Vertrouwende op uw medewerking, verblijf ik,

Hoogachtend,

Mevr. J.H. van Lokven, voorzitter. 


\section{Brief 2}

Invulinstructies: voor-en nameting

Begeleidingscommissie

t.b.v. onderzoek naar thuiszorg

p/a drs. G. van Berkum

Postbus 6666

5500 MA Veldhoven

Veldhoven, datum

Aan alle ouders en verzorgers

die hun medewerking verlenen aan

het onderzoek naar thuiszorg

Geachte mevrouw, mijnheer,

Wij zijn erg blij dat u uw medewerking wilt verlenen aan het onderzoek naar verschillende vormen van hulp. Bij deze sturen wij $u$, zoals afgesproken, de vragenlijst toe.

De vragenlijst bestaat uit zes gedeeltes. In het eerste gedeelte worden vragen gesteld over de handicap of de achterstand van uw zoon of dochter. Het tweede gedeelte bevat vragen over de andere leden van uw gezin (uw andere kinderen en/of uw partner). Het derde gedeelte van de vragenlijst heeft betrekking op verschillende soorten hulpverlening waarvan ouders gebruik kunnen maken. In het vierde gedeelte worden vragen gesteld over moeilijkheden die u wellicht ervaart in verband met de handicap of de achterstand van uw zoon of dochter, over manieren waarop u deze problemen probeert op te lossen en over de hulp die u hierbij van anderen ontvangt. In het vijfde gedeelte worden enige vragen gesteld over uw eigen lichamelijke en geestelijke gezondheid. De vragenlijst wordt afgesloten met een aantal vragen naar uw personalia. Aan het einde van elk gedeelte en aan het einde van de gehele vragenlijst zijn ruimtes opengelaten waar u opmerkingen over de vragen kunt maken, als u daaraan behoefte heeft.

De vragenlijst is vrij uitgebreid. $U$ kunt naturrijk alle vragen achter elkaar beantwoorden, maar het is wellicht aan te raden na het derde gedeelte van de vragenlijst even een pauze in te lassen. U kunt, als u wat minder tijd heeft, de vragen ook deel voor deel beantwoorden. Naar schatting zal het invullen van de vragenlijst u eén tot anderhalf uur tijd kosten. 
De meeste vragen gaan over persoonlijke gevoeiens, ervaringen en meningen. Wij zouden het dan ook zeer op prijs stellen wanneer de vragenlijst door tén van de ouders ingevuld wordt. Aangezien de ervaring leert dat moeders zich in het algemeen het meest bezighouden met het gezin, verzoeken wij de moeders de vragen te beantwoorden. Als dat, om welke reden dan ook, niet kan, kunnen de vragen natuurlijk ook door de vaders beantwoord worden.

Wij benadrukken nogmaals dat uw antwoorden volstrekt vertrouwelijk behandeld en verwerkt zullen worden: niemand krijgt inzage in de gegevens die u verstrekt en de vragenlijsten zullen vernietigd worden zodra uw antwoorden verwerkt zijn. In het uiteindelijke verslag is niet na te gaan welke antwoorden $u$ of enige andere ouder of verzorger gegeven heeft.

De vragenlijst is geen test: er zijn geen goede of foute antwoorden. Lees voor u de vragen gaat beantwoorden, eerst de instructies bij het invullen van de vragenlijst goed door. Lees vervolgens de vragen rustig en op uw gemak. Denk evenwel niet te lang na voor u de vragen beantwoordt: vaak geeft een eerste reactie het beste uw gedachten en gevoelens weer.

De vragenlijst wordt weer bij u opgehaald: de afgesproken datum vindt $u$ op de voorkant van de vragenlijst. Daar treft u ook mijn telefoonnummer aan, waar u mij kunt bereiken voor vragen of opmerkingen.

Wij wensen a veel succes met het beantwoorden van de vragen.

Hoogachtend,

Mevr. drs. G. van Berkum, onderzoeker. 


\section{Brief 3}

Introductie van het onderzoek: nameting

Begeleidingscommissie

t.b.v. onderzoek naar thuiszorg

p/a drs. G. van Berkum

Postbus 6666

5500 MA Veldhoven

Veldhoven, datum

Aan alle ouders en verzorgers die

gebruik maken of hebben gemaakt van:

Weekendopvang

Praktische Thuishulp

Praktisch Pedagogische Gezinsbegeleiding

Geen van deze hulpvormen

Geachte ouders en verzorgers,

Ongeveer een jaar geleden heeft $\mathrm{u}$ uw medewerking verleend aan een onderzoek naar verschillende vormen van thuiszorg die worden aangeboden aan ouders en verzorgers van een thuis wonend kind met een ontwikkelingsachterstand of een verstandelijke handicap. De onderzochte vormen van hulp waren:

(1) De projecten Weekendopvang die in de vakantieboerderij in Veldhoven, het kinderdagverblijf "De Elzengaard" in Den Bosch en het kinderdagverblijf "Het Zonnelicht" in Tilburg georganiseerd worden gedurende enkele weekends per jaar ter ontlasting van het gezin;

(2) De Praktische Thuishulp voor hulp bij praktische problemen, zoals bijvoorbeeld oppas;

(3) Praktisch Pedagogische Gezinsbegeleiding voor ondersteuning bij moeilijkheden in de opvoeding van en de omgang met het kind.

De drie genoemde hulpvormen proberen ouders en verzorgers hulp to bieden bij verschillende moeilijkheden die het thuis grootbrengen een kind met een verstandelijke handicap of een ontwikkelingsachterstand met zich kan brengen.

Het onderzoek naar deze hulpvormen richt zich met name op de vraag welke effecten de hulp heeft op de belasting die ouders en verzorgers ervaren. Zoals u zich wellicht nog herimnert, heeft $\mathrm{u}$ vorig jaar een uitgebreide vragenlijst ingevuld ten behoeve van dit onderzoek. Het onderzoek is nu zijn laatste fase ingegaan: wij willen daarom nogmaals een beroep op u doen om voor een tweede en tevens laatste maal een vragenlijst in te vullen. 
Om de vraagstelling van het onderzoek zo goed mogelijk te kunnen beantwoorden, doen wij een beroep op alle ouders en verzorgers die het afgelopen jaar gebruik gemaakt hebben van eén of meer van de genoemde hulpvormen om nogmaals hun medewerking aan het onderzoek te verlenen. Ook zouden wij het op prijs stellen als de ouders en verzorgers die geen gebruik gemaakt hebben van deze hulpvormen, zouden meewerken aan het onderzoek: hun antwoorden zijn onontbeerlijk als vergelijkingsmateriaal.

De vragenlijst is voor een groot gedeelte gelijk aan de lijst die u het afgelopen jaar heeft ingevuld. Naast vragen over de Weekendopvang, Praktische Thuishulp en Praktisch Pedagogische Gezinsbegeleiding, bevat de vragenlijst vragen over uw zoon of dochter met een ontwikkelingsachterstand of verstandelijke handicap, over uw eventuele andere kind(eren), over uw eigen gezondheid, over moeilijkheden die u wellicht ervaart nu $\mathfrak{u}$ een kind met een achterstand heeft en over uw personalia. Al deze vragen zijn bedoeld om na te gaan of er zich in de loop van het afgelopen jaar veranderingen in uw situatie hebben voorgedaan. Het invullen van de vragenlijst zal ongeveer én tot anderhalf uur tijd kosten.

Wij willen u er met nadruk op wijzen dat de antwoorden die u geeft, volstrekt vertrouwelijk worden behandeld. Niemand anders dan de onderzoekster krijgt inzage in de gegevens die u verstrekt, de vragenlijst zal worden vernietigd zodra uw antwoorden verwerkt zijn en in het eindverslag is niet na te gaan welke antwoorden u of enig andere ouder of verzorger gegeven heeft. Als het onderzoek is afgerond, krijgen alle ouders en verzorgers die eraan meegewerkt hebben, een samenvatting van de resultaten.

Wij zouden het zeer waarderen als u nogmaals uw medewerking aan het onderzoek wilt verlenen. Ik zal binnenkort contact met u opnemen om uw medewerking te vragen. Mocht u vóor die tijd nog vragen hebben, dan kunt a daarmee bij mij terecht.

Vertrouwende op uw medewerking,

Hoogachtend,

Mevr. drs. G. van Berkum, onderzoeker. 
BIJLAGE C Tabellen stressmodellen (Hoofdstuk 7)

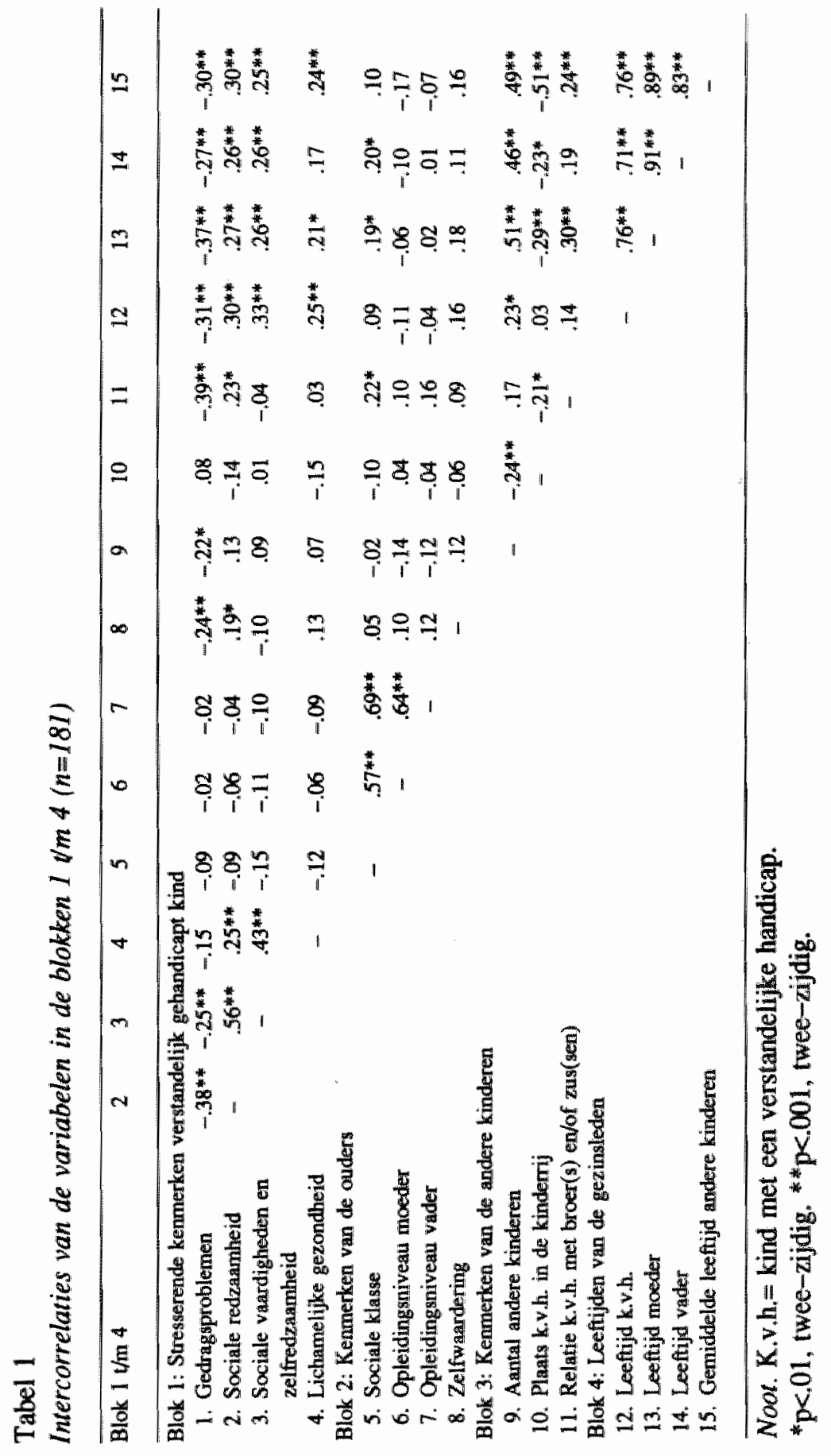


Tabel 2

Pearson correlaties tussen de variabelen in de blokken 1 t/m 4 en de copingstijlen, blok $7(n=181)$

Blok 7: Coping

Bilok 1 thm 4

\begin{tabular}{lllll}
\hline Depressief & Sociale & Palliatieve & Vermij- & Expres- \\
reactie- & steun & reactie & ding & sie van \\
patroon & zoeken & & & emoties
\end{tabular}

BLok 1: Stresserende kenmerken verstandelijk gehandicapt kind

1. Gedraggenoblemen

2. Socialie redzamineid

3. Socilale vardigheden en zelfredzamheid

4. Lichamelijke gezondheid

Blok 2: Kenmerken van de oudera

\section{Sociale klasse}

6. Opleidingsmiveau moeder

7. Opleiding gniveau vader

8. Zelfwaardering

$$
.35 \text { * }
$$$$
-19 *
$$

$-.02$

$-.11$

$-.08$

$-.43^{* *}$

Blok 3: Kenmerken van de andere kinderen

9. Aantal andere kinderen

10. Plaats k.v.h. in de kinderrij

11. Relatie $k \cdot v \cdot h$ met broer(s) en/of zus(sen)

$-.03$

O6

.194
$.22 *$

$-.20 *$

$-.11-10$

$-.18-.05$

$.18 \quad-.02$

$.23 * \quad-.01$

$.23 * \quad-.02$

$-.03 \quad-.01$
$.20 *$

$-.01$

$-.04$

$-.03$
$-.09$

$20 *$

$-.10$

01

Blok 4: Leeftijden van de gezinsleden

12. Leeftijd k.v.h.

$-.13$

$-.12$

.06

$-.03$

$-.07 \quad-.02$

$-.04$

$-.14 \quad .04$

.02

$-.01$

$-.13$

$-.01$

$-.10$

$-.01$

$-.17$

$-25 * *$

14. Leeftijd vader

$-.11$

$\begin{array}{rr}.01 & -.15 \\ .04 & .17 \\ -.03 & .08\end{array}$

15. Gemiddelde leeftijd andere kinderen

\section{Noot. K.v.h.= kind met een verstandelijke handicap.}

${ }^{*} \mathrm{p}<.01$, twee-zijdig. ${ }^{* *}$ p $<.001$, twee-zijdig. 
Tabel 3

Resultaten van de hiërarchische multiple regressie analyse ten aanzien wan het copingmodel, met als afhankelijke variabele het psychosomatisch onwelbevinden en met als predictoren de determinanten uit het basismodel, de copingstijlen en de interacties tussen de copingstijlen en de concrete problemen van ouders ( $n=181$ )

\begin{tabular}{lllll}
\hline Stap Variabele & r & B & $\mathbb{R}^{2}$
\end{tabular}

1. Determinanten basismodel
a. Gezinsverstoring
b. Zelfwraardering
c. Opleidingsniveans moeder

$\begin{array}{lc}.61^{* *} & .31^{* *} \\ -.61^{* *} & -.31^{* *} \\ -.16 & -.19^{* *} \\ & \\ .59 * * & .30^{* *} \\ .12 & .15 \\ .09 & -.01 \\ .24^{*} & .07 \\ .33^{* *} & .06\end{array}$

.52

2. Copingstijlen
a. Depressief reactiepatroon (D)
b. Sociale steun zoeken (S)
c. Palliatieve reactie (P)
d. Vermijding (V)
e. Expressie van emoties (E)
.09

3. Interacties copingstijlen met concrete problemen
a. D* gezinsverstoring
b. D* praktische druk

c. D* problemen m.b.t. de partner

d. $D *$ zorgen over de ontwikkeling van de andere kinderen

e. $S$ * gezinsverstoring

f. $S *$ praktische drulk

.18* -14

$-.02 \quad-.01$

$.14 \quad .07$

$.16 \quad .03$

g. S problemen m.b.t. de partner

$.13 \quad .06$

$.09 \quad-.13$

$.10 \quad .01$

h. S * zorgen over de ontwikkelling

$.19 * \quad .13$

van de andere kinderen

i. $P *$ gezinsverstoring

$.05 \quad .09$

j. P* praktische druk

$-.05 \quad .01$
-.02

k. $\quad$ * problemen m.b.t. de partner

$-.02 \quad-.01$

1. $\quad P^{*}$ zorgen over de ontwikkeling.

$.03 \quad .13$

van de andere kinderen

m. $V *$ gezinsverstoring

n. V* praktische druk

$-.04 \quad-.03$

a. V* problemen m.b.t. de partner $\quad .04 \quad-.03$

p. V* zorgen over de ontwikkeling $\quad .03 \quad-.07$ van de andere kinderen

q. $\mathbb{E} *$ gezinswerstoring $\quad .04 \quad .01$

r. E praktische druk $\quad-.05 \quad .08$

s. E * problemen m.b.t. de partner $\quad .01 \quad .02$

t. E zorgen over de ontwikkeling $\quad-.02 \quad-.04$ van de andere kinderen

Noot. De bêta's zijn de standaardpartièle regressiecoèfficięnten na stap 3 . ${ }^{*} \mathrm{p}<.01$, twee-zijdig. ${ }^{* *} \mathrm{p}<.001$, twee-zijdig. 
Tabel 4

Pearson correlaties tussen de variabelen uit de blokken 1 ym 4 en de indices voor sociale steun, blok $8(n=181)$

Blok 8: Sociale steun

Blok 1 th 4

\begin{tabular}{|c|c|c|c|c|c|}
\hline $\begin{array}{l}\text { Burget- } \\
\text { lijke } \\
\text { stat }\end{array}$ & $\begin{array}{l}\text { Parther- } \\
\text { steun }\end{array}$ & $\begin{array}{l}\text { Totalal } \\
\text { anntal } \\
\text { gteun- } \\
\text { gevenden }\end{array}$ & $\begin{array}{l}\text { Lid- } \\
\text { miatat- } \\
\text { schap } \\
\text { geloofs- } \\
\text { gemeen- } \\
\text { schap }\end{array}$ & $\begin{array}{l}\text { Steun } \\
\text { uit } \\
\text { gelloof }\end{array}$ & $\begin{array}{l}\text { Sociale } \\
\text { isuolatie }\end{array}$ \\
\hline
\end{tabular}

Blok 1: Stresserende kenmerken verstandelijtik gehandicapt kind

1. Gedraggproblemen $\quad .03 \quad-.01 \quad-.0$

2. Sociale redzanmeid $\quad-.07 \quad-.02 \quad-.02$

$\begin{array}{llll}.01 & .04 & -.16 & .22\end{array}$

3. Socialle vaardigheden

$-.07 \quad .02 \quad-.10$

$\begin{array}{rrr}.07 & .12 & -.15\end{array}$

en zelfiredxaamheid

4. Lichameligke gezondheid

$-.11$

.05

$-25 \%$

$\begin{array}{lll}.04 & -.02 & -.14\end{array}$

Blok 2, Kenmerken van de ouders

$\begin{array}{lrrrrrr}\text { 5. Sociale klasse } & .26 * & -.05 & .01 & -.19 & .09 & -.12 \\ \text { 6. Opleidingsniveau moeder } & .15 & .06 & .04 & -.29 * & .05 & -.08 \\ \text { 7. Opleidingsniveau vader } & .04 & -.10 & -.02 & -.24 * & .12 & -.14 \\ \text { 8. Zelfwiardering } & -.01 & .01 & .07 & -.05 & .05 & -.23 *\end{array}$

Blok 3: Kenmerken van de andere kinderen

9. Aantal andere kinderen $\quad-11$

10. Plaats k.v.h. in de $\quad .02$

$$
-.12 \quad-.13
$$

$-.13$

.04

$.11-\quad-.07 \quad-.08$

\section{kinderrij}

11. Relativ k.v.h. met

.04

$\begin{array}{lll}-.06 & -.14 & .10\end{array}$

broer(s) en/of zus(sen)

.06

$-.04$

$.16-.20$

Blok 4: Leeftijden van de gezinsleden
12. Leeftijjd k.w.h.
$-.17 \quad-.07$
$-.05$
.02
.14 .03
13. Leeftijd moeder
$-16 \quad-.10$
$-.04$
$-.01$
$.23 * \quad-.02$
14. Leeftijd wader
$-.00 \quad-.13$
.01
$-{ }_{-} 01$
$.24 * .03$
15. Gemiddelde leeftijd
$-.15 \quad-.10$
$-.01$
.22 *
.01

Noot. K.v.h. $=$ kind met een verstandelijke handicap.

${ }^{*}$ p<..01, twee-zijdig. ${ }^{* *}$ p<.001, twee-zijdig. 


\section{Tabel 5}

Resultaten van de hiërarchische multiple regressie analyse ten aanzien van het sociale-steunmodel met als afhankelijke variabele het psychosomatisch onwelbevinden en met als predictoren de determinanten uit het basismodel, de indices voor sociale steun en de interacties tussen de indices voor sociale steun en de concrete problemen van ouders $(n=181)$

\begin{tabular}{lllll}
\hline Stap Variabelen & I & $B$ & $R^{2}$
\end{tabular}

1. Determinanten basismodel
a. Gezinsverstoring
b. Zelfwaardering.
c. Opleidingsniveau moeder

$\begin{array}{ll}.61 * * & .40 * * \\ -.61 * * & -.39 * * \\ -.16 & -.09\end{array}$

2. Sociale steun
a. Burgerlijke staat (B)
b. Partnersteun (P)
c. Totale aantal steungevenden (Ts)
d. Lidmaatschap geloofsgemeenschap (L)
e. Steun uit geloof $(\mathrm{Sg})$
f. Sociale isolatie (Si)

$\begin{array}{rr}-.08 & .02 \\ .01 & -.02\end{array}$
$.01 \quad-.02$
$-.04 \quad-.03$
$.17 \quad .13$
$-.02 \quad .08$
$.46^{* *} \quad .18 *$

3. Interacties sociale steun met concrete problemen
a. $\mathrm{B} *$ gezinsverstoring
b. $B *$ praktische druk
$.04 \quad .10$
$.06 \quad .01$
c. B * problemen m.b.t. de partner
$.42 * *-.02$
d. $\mathrm{B} *$ zorgen over de ontwikkeling vd andere kinderen $\quad .01 \quad-.06$
e. $\mathbf{P} *$ gezinsverstoring
f. $\mathbf{P} *$ praktische druk
$.04 \quad-.02$
g. $\quad$ * problemen m.b.t. de partner
$.05 \quad .12$
$.08 \quad-.04$
b. $\mathrm{P} *$ zorgen over de ontwikkeling vd andere kinderen $\quad-.01 \quad-.07$
i. Ts * gezinsverstoring
j. Ts * praktische druk
k. Ts * problemen m.b.t. de parner
$.05 \quad-.10$
$.18 * \quad .11$
$.20 * \quad .09$
L. Ts * zorgen over de ontwikkeling vd andere kinderen $\quad .10 \quad-.01$
m. L * gezinsverstoring
n. L * praktische druk
o. L * problemen m.b.t. de partner
$.12 \quad .01$
$.14 \quad .03$
$.17 \quad .08$
p. L * zorgen over de ontwikkeling vd andere kinderen
$.10 \quad .03$
q. $\mathrm{Sg} *$ gezinsverstoring
r. $\quad \mathrm{Sg} *$ praktische druk
s. $\quad \mathrm{Sg} *$ problemen m.b.t. de partner
$-.02 \quad .14$
$-.02 \quad .02$
$\begin{array}{ll}-.02 & -.07\end{array}$
t. $\mathrm{Sg} *$ zorgen over de ontwikkeling vd andere kinderen $\quad-.05 \quad-.05$
u. Si * gexinswerstoring
v. Si * praktische druk
w. Si * problemen m.b.t. de partner
$\mathrm{x} . \quad \mathrm{Si}$ * zorgen over de ontwikkeling vd andere kinderen

$\begin{array}{rr}.17 & .03 \\ .08 & .12 \\ .07 & -.06 \\ .08 & -.03\end{array}$

\section{$\mathrm{R}^{2}$}





\section{BLJLAGE D Tabellen voormeting (Hoofdstuk 8)}

\section{Tabel 1}

Gemiddelden en standaarddeviaties van de variabelen in de blokken 3, 4,7 en 8 van de controle - en de hulpverleningsgroepen: voormeting

\begin{tabular}{|c|c|c|c|c|}
\hline \multirow[b]{2}{*}{ Variabelen } & \multicolumn{4}{|c|}{ Groepen } \\
\hline & $\begin{array}{l}\text { Controle } \\
(\mathrm{n}=60)\end{array}$ & $\begin{array}{l}\text { PPG } \\
(n=58)\end{array}$ & $\begin{array}{l}\mathrm{PT} \\
(\mathrm{n}=25)\end{array}$ & $\begin{array}{l}\text { Wo } \\
(n=64)\end{array}$ \\
\hline \multicolumn{5}{|c|}{ Blok 3: Kenmerken van de andere kinderen } \\
\hline 1. Aantal andere kinderen & $\begin{array}{l}1.69 \\
(.95)\end{array}$ & $\begin{array}{l}1.69 \\
(.92)\end{array}$ & $\begin{array}{l}1.62 \\
(.87)\end{array}$ & $\begin{array}{l}1.79 \\
(1.09)\end{array}$ \\
\hline $\begin{array}{l}\text { 2. Relatie k.v.h. met broer(s) } \\
\text { en/of zus(sen) }\end{array}$ & $\begin{array}{l}2.86 \\
(33)\end{array}$ & $\begin{array}{l}2.22 * \\
(73)\end{array}$ & $\begin{array}{l}2.66^{*} \\
(.31)\end{array}$ & $\begin{array}{l}2.56 * \\
(.63)\end{array}$ \\
\hline \multicolumn{5}{|l|}{ Blok 4: Leeftijden van de gezinsleden } \\
\hline 3. Leeftijd k.v.h. & $\begin{array}{l}10.7 \\
(6.5)\end{array}$ & $\begin{array}{l}7.1^{* * *} \\
(5.8)\end{array}$ & $\begin{array}{l}9.0 \\
(7.5)\end{array}$ & $\begin{array}{l}12.2 \\
(4.8)\end{array}$ \\
\hline 4. Leeftijd moeder & $\begin{array}{l}40.2 \\
(8.9)\end{array}$ & $\begin{array}{l}33.8^{* * * *} \\
(6.8)\end{array}$ & $\begin{array}{l}37.7 \\
(9.5)\end{array}$ & $\begin{array}{l}40.1 \\
(6.6)\end{array}$ \\
\hline 5. Leeftijd vader & $\begin{array}{l}41.9 \\
(8.8)\end{array}$ & $\begin{array}{l}36.2^{* * * *} \\
(7.4)\end{array}$ & $\begin{array}{l}37.0 \\
(6.6)\end{array}$ & $\begin{array}{l}42.6 \\
(6.6)\end{array}$ \\
\hline $\begin{array}{l}\text { 6. Gemiddelde leeftijd andere } \\
\text { kinderen }\end{array}$ & 13 & $\begin{array}{l}8.0^{* * 1} \\
(6.2)\end{array}$ & $\begin{array}{l}8.1 \\
(7.8)\end{array}$ & $\begin{array}{l}12.3 \\
(7.0)\end{array}$ \\
\hline \multicolumn{5}{|l|}{ Blok 7: Coping } \\
\hline 7. Sociale steun zoeken & $\begin{array}{l}2.47 \\
(.66)\end{array}$ & $\begin{array}{l}2.66 \\
(.62)\end{array}$ & $\begin{array}{l}2.75 \\
(.54)\end{array}$ & $\begin{array}{l}2.62 \\
(.61)\end{array}$ \\
\hline 8. Palliatieve reactie & $\begin{array}{l}1.94 \\
(.84)\end{array}$ & $\begin{array}{l}2.07 \\
(.81)\end{array}$ & $\begin{array}{l}2.23 \\
(.92)\end{array}$ & $\begin{array}{l}2.07 \\
(.81)\end{array}$ \\
\hline 9. Vermijding & $\begin{array}{l}1.94 \\
(.77)\end{array}$ & $\begin{array}{l}2.01 \\
(.55)\end{array}$ & $\begin{array}{l}2.10 \\
(.45)\end{array}$ & $\begin{array}{l}1.98 \\
(.37)\end{array}$ \\
\hline 10. Expressie van emoties & $\begin{array}{l}2.31 \\
(.77)\end{array}$ & $\begin{array}{l}2.38 \\
(.73)\end{array}$ & $\begin{array}{l}2.04 \\
(.78)\end{array}$ & $\begin{array}{l}2.54 \\
(.78)\end{array}$ \\
\hline \multicolumn{5}{|l|}{ Blok 8: Sociale steun } \\
\hline 11. Totaal aantal steungewenden & $\begin{array}{l}2.59 \\
(1.04)\end{array}$ & $\begin{array}{l}2.31 \\
(1.06)\end{array}$ & $\begin{array}{l}2.71 \\
(.96)\end{array}$ & $\begin{array}{l}2.43 \\
(1.17)\end{array}$ \\
\hline 12. Steun uit geloof & $\begin{array}{l}1.40 \\
(.72)\end{array}$ & $\begin{array}{l}1.22 \\
(.55)\end{array}$ & $\begin{array}{l}1.77 \\
(.83)\end{array}$ & $\begin{array}{l}1.30 \\
(.63)\end{array}$ \\
\hline
\end{tabular}

Noot. K.v.h.= kind met een verstandelijke handicap.

Verschil met de controlegroep:

${ }^{*} p<.05$, twee-zijdig. ${ }^{* *}$ p<.01, twee-zijdig. ${ }^{* * *}$ p<.001, twee-zijdig. 
Tabel 2

Frequenties van de variabelen in de blokken 1,4 en 8 van de controle- en de hulpverleningsgroepen: voormeting

\section{Groepen}

Variabelen

\begin{tabular}{llll}
\hline Conitrole & PPG & PT & WO \\
$(n=60)$ & $(n=58)$ & $(n=25)$ & $(n=64)$
\end{tabular}

1. Geslacht verstandelijk gehandicapt kind meisje jongen

$\begin{array}{lcc}19 & 9 & 28 \\ 39^{* * *} & 16 & 36\end{array}$

Blok 4: Kenmerken van de andere kinderen

2. Plaats k.w.h. in de kinderril

$\begin{array}{lcccc}\text { jongste kind } & 29 & 14 & 7 & 24 \\ \text { middellste kind } & 5 & 8 & 4 & 11 \\ \text { oudste kind } & 17 & 17 & 10 & 23 \\ \text { enig kind } & 9 & 19 * * & 4 & 6^{*}\end{array}$

Blok 8: Sociale steun

3. Burgerlijke staat gehusud alleenstaand

$\begin{array}{cccc}57 & 48 & 23 & 61 \\ 3 & 10^{* *} & 2 & 3 \\ 37 & 31 & 13 & 44 \\ 12 & 17 & 8 & 14 \\ 49 & 53 & 17 & 57 \\ 11 & 5 & 8 & 7\end{array}$

Noot. K.v.h. $=$ kind met een verstandelijke handicap.

Verschil met de controlegroep: ${ }^{*} p<.01$, twee-zijdig. ${ }^{* *} p<.001$, twee-zijdig. 


\section{Tabel 1}

Gemiddelden en standaarddeviaties van de variabelen in de blokken $2 \forall m 4,7$ en 8 van de controle - en de hulpverleningsgroepen: nameting

\begin{tabular}{|c|c|c|c|c|}
\hline \multirow[b]{2}{*}{ Variabelen } & \multicolumn{4}{|c|}{ Groepen } \\
\hline & $\begin{array}{l}\text { Controle } \\
(n=47)\end{array}$ & $\begin{array}{l}\mathrm{PPG} \\
(\mathrm{n}=48)\end{array}$ & $\begin{array}{l}\mathrm{PT} \\
(\mathrm{n}=11)\end{array}$ & $\begin{array}{l}\text { Wo } \\
(\mathrm{n}=42)\end{array}$ \\
\hline \multicolumn{5}{|l|}{ Blok 2: Kenmerken wan de ouders } \\
\hline 1. Sociale klasse & $\begin{array}{l}3.59 \\
(1.44)\end{array}$ & $\begin{array}{l}2.60 * * \\
(1.32)\end{array}$ & $\begin{array}{l}4.18 \\
(1.54)\end{array}$ & $\begin{array}{l}3.79 \\
(1.70)\end{array}$ \\
\hline 2. Opleidingsnivenu moeder & $\begin{array}{l}2.87 \\
(1.33)\end{array}$ & $\begin{array}{l}2.71 \\
(1.43)\end{array}$ & $\begin{array}{l}3.73 \\
(1.85)\end{array}$ & $\begin{array}{l}3.02 \\
(1.57)\end{array}$ \\
\hline 3. Opleidingsniveau vader & $\begin{array}{l}3.49 \\
(1.66)\end{array}$ & $\begin{array}{l}2.83 \\
(1.63)\end{array}$ & $\begin{array}{l}4.27 \\
(2.10)\end{array}$ & $\begin{array}{l}3.95 \\
(2.04)\end{array}$ \\
\hline \multicolumn{5}{|c|}{ Blok 3: Kenmerken van de andere kinderen } \\
\hline 4. Aantal andere kinderen & $\begin{array}{l}1.73 \\
(1.04)\end{array}$ & $\begin{array}{l}1.58 \\
(.79)\end{array}$ & $\begin{array}{l}1.89 \\
(1.10)\end{array}$ & $\begin{array}{l}1.84 \\
(1.03)\end{array}$ \\
\hline $\begin{array}{l}\text { 5. Relatie k.v.h. met broer(s) } \\
\text { en/of zus(sen) }\end{array}$ & $\begin{array}{l}2.68 \\
(57)\end{array}$ & $\begin{array}{l}2.34 * \\
(.57)\end{array}$ & $\begin{array}{l}2.56 \\
(.62)\end{array}$ & $\begin{array}{l}2.68 \\
(.50)\end{array}$ \\
\hline \multicolumn{5}{|l|}{ Blok 4: Leeftijden van de gezinsleden } \\
\hline 6. Leeftijd k.v.h. & $\begin{array}{l}11.2 \\
(6.0)\end{array}$ & $\begin{array}{l}8.0^{*} \\
(6.0)\end{array}$ & $\begin{array}{l}7.6 \\
(4.2)\end{array}$ & $\begin{array}{l}13.1 \\
(5.0)\end{array}$ \\
\hline 7. Leeftijd moeder & $\begin{array}{l}40.5 \\
(8.2)\end{array}$ & $\begin{array}{l}34.7^{* *} \\
(7.0)\end{array}$ & $\begin{array}{l}35.8 \\
(5.8)\end{array}$ & $\begin{array}{l}41.2 \\
(6.2)\end{array}$ \\
\hline 8. Leeftijd vader & $\begin{array}{l}41.5 \\
(8.3)\end{array}$ & $\begin{array}{l}37.4^{*} \\
(7.2)\end{array}$ & $\begin{array}{l}38.9 \\
(6.9)\end{array}$ & $\begin{array}{l}43.8 \\
(6.4)\end{array}$ \\
\hline $\begin{array}{l}\text { 9. Gemiddelde leeftijd andere } \\
\text { kinderen }\end{array}$ & $\begin{array}{l}13.2 \\
(8.1)\end{array}$ & $\begin{array}{l}9.1 * \\
(6.4)\end{array}$ & $\begin{array}{l}8.6 \\
(6.8)\end{array}$ & $\begin{array}{l}13.0 \\
(6.4)\end{array}$ \\
\hline \multicolumn{5}{|l|}{ Blok 7: Coping } \\
\hline 10. Sociale steun zoeken & $\begin{array}{l}2.36 \\
(.56)\end{array}$ & $\begin{array}{l}2.55 \\
(.61)\end{array}$ & $\begin{array}{l}3.00^{* *} \\
(.46)\end{array}$ & $\begin{array}{l}2.66 \\
(.57)\end{array}$ \\
\hline 11. Palliatieve reactie & $\begin{array}{l}1.97 \\
(.74)\end{array}$ & $\begin{array}{l}1.91 \\
(.78)\end{array}$ & $\begin{array}{l}2.32 \\
(.82)\end{array}$ & $\begin{array}{l}2.02 \\
(.83)\end{array}$ \\
\hline 12. Vermijding & $\begin{array}{l}1.99 \\
(.44)\end{array}$ & $\begin{array}{l}1.97 \\
(.44)\end{array}$ & $\begin{array}{l}2.00 \\
(.21)\end{array}$ & $\begin{array}{l}2.03 \\
(.45)\end{array}$ \\
\hline 13. Expressie wan emoties & $\begin{array}{l}2.20 \\
(.82)\end{array}$ & $\begin{array}{l}2.48 \\
(.85)\end{array}$ & $\begin{array}{l}2.23 \\
(.79)\end{array}$ & $\begin{array}{l}2.49 \\
(.77)\end{array}$ \\
\hline Blok 8: Socialle steun & & & & \\
\hline 14. Totaal astal steungevenden & $\begin{array}{l}2.45 \\
(.98)\end{array}$ & $\begin{array}{l}2.25 \\
(1.24)\end{array}$ & $\begin{array}{l}3.00 \\
(1.40)\end{array}$ & $\begin{array}{l}2.46 \\
(1.17)\end{array}$ \\
\hline 15. Steun uit geloof & $\begin{array}{l}1.33 \\
(.72)\end{array}$ & $\begin{array}{l}1.32 \\
(.61)\end{array}$ & $\begin{array}{l}1.13 \\
(.35)\end{array}$ & $\begin{array}{l}1.36 \\
(.71)\end{array}$ \\
\hline
\end{tabular}

Noot. K.v.h. $=$ kind met een verstandelijke handicap.

Verschil met de controlegroep: ${ }^{*} p<.05$, twee-zijdig. **p<.001, twee-zijdig. 


\section{Tabel 2}

Frequenties van de variabelen in de blokken 1,4 en 8 van de controle- en de hulpverleningsgroepen: nameting

\begin{tabular}{|c|c|c|c|c|}
\hline \multirow[b]{2}{*}{ Variabelen } & \multicolumn{4}{|c|}{ Groepen } \\
\hline & $\begin{array}{l}\text { Controle } \\
(n=47)\end{array}$ & $\begin{array}{l}P P G \\
(n=48)\end{array}$ & $\begin{array}{l}\text { PT } \\
(\mathrm{n}=11)\end{array}$ & $\begin{array}{l}\text { WO } \\
(m=42)\end{array}$ \\
\hline \multicolumn{5}{|c|}{ 1. Geslacht verstandelijk gehandicapt kind } \\
\hline meisje & 25 & 17 & 4 & 18 \\
\hline jongen & 22 & $31^{*}$ & 7 & 24 \\
\hline \multicolumn{5}{|c|}{ Blok 4: Kenmerken van de andere kinderen } \\
\hline \multicolumn{5}{|c|}{ 2. Plavats k.v.h. in de kinderrij } \\
\hline jongste kind & 25 & 13 & 4 & 18 \\
\hline middelste kind & 3 & 6 & 2 & 6 \\
\hline oudste kind & 12 & 14 & 2 & 14 \\
\hline enig kind & 7 & $15^{* * *}$ & 3 & 4 \\
\hline \multicolumn{5}{|l|}{ Blok 8: Sociale steun } \\
\hline \multicolumn{5}{|l|}{ 3. Burgerlijke staat } \\
\hline gehuwrd & 45 & 41 & 10 & 40 \\
\hline alleenstaand & 2 & $7^{*}$ & 1 & 2 \\
\hline \multicolumn{5}{|l|}{ 4. Partnersteun } \\
\hline ja & 24 & 22 & 7 & 26 \\
\hline nee & 14 & 19 & 2 & 13 \\
\hline \multicolumn{5}{|c|}{ 5. Lidmaatschap geloofisgemeenschap } \\
\hline ja & 39 & 43 & 8 & 40 \\
\hline nee. & 7 & 5 & 3 & 2 \\
\hline
\end{tabular}

Noot. K.v.h.= kind met een verstandelijke handicap.

Verschill met de controlegroep: * $\mathrm{p}<.05$, twee-zijdig. ${ }^{* *} \mathrm{p}<.001$, twee-zijdig. 


$\begin{array}{ll}\text { AAW } & \text { Algemene Arbeidsongeschiktsheids Wet } \\ \text { ABV } & \text { Amsterdamse Biografische Vragenlijst } \\ \text { ANCOVA } & \text { Covariantie analyse } \\ \text { ANOVA } & \text { Variantie analyse } \\ \text { AWBZ } & \text { Algemene Wet Bijzondere Ziektekosten } \\ \text { BLO } & \text { Buitengewoon lager onderwijs } \\ \text { CWZ } & \text { Centrale Wachtlijst Zwakzinnigen } \\ \text { DSM-III-R } & \text { Diagnostic and Statistical Manual of Mental Diorders (third } \\ & \text { edition revised) } \\ \text { DVO } & \text { Dagverblijf voor ouderen } \\ \text { HSCL } & \text { Hopkins Symptom Checklist } \\ \text { KDV } & \text { Kinderdagverblijf } \\ \text { MANCOVA } & \text { Multivariate covariantie analyse } \\ \text { MANOVA } & \text { Multivariate variantie analyse } \\ \text { MDGO } & \text { Middelbaar Dienstverlenend en Gezondheids Onderwijs } \\ \text { MLK } & \text { (School voor) moeilijk lerende kinderen } \\ \text { MMPI } & \text { Minnesota Multiphasic Personality Inventory } \\ \text { NPV } & \text { Nederlandse Persoonlijkheids Vragenlijst } \\ \text { PPG } & \text { Praktisch Pedagogische Gezinsbegeleiding } \\ \text { PT } & \text { Praktische Thuishulp } \\ \text { QRS } & \text { Questionnaire on Resources and Stress } \\ \text { QRS-F } & \text { Questionnaire on Resources and Stress Short-Form } \\ \text { ROZ } & \text { Regionaal Overlegorgaan Zwakzinnigenzorg } \\ \text { SCL-90 } & \text { Symptom Checklist } \\ \text { SGZ } & \text { Storend Gedragsschaal voor Zwakzinnigen } \\ \text { SRK } & \text { Sociale Redzaamheidsschaal voor Kinderdagverblijfbezoekers } \\ \text { SRZ } & \text { Sociale Redzaamheidsschaal voor Zwakzinnigen } \\ \text { SPD } & \text { Sociaal Pedagogische Dienst } \\ \text { UCL } & \text { Utrechtse Coping Lijst } \\ \text { VOEG } & \text { Vragenlijst voor Onderzoek naar de Ervaren Gezondheidstoe- } \\ & \text { stand } \\ \text { VTO } & \text { Vroegtijdige Onderkenning van Ontwikkelingsstoornissen } \\ \text { WCC } & \text { Ways Of Coping Checklist } \\ \text { WO } & \text { Weekendopvang } \\ \text { ZMLK } & \text { (School voor) zeer moeilijk lerende kinderen } \\ & \end{array}$





\section{CURRICULUM VITAE}

Hillegonda W. van Berkum werd op 15 februari 1957 in Hengelo (O) geboren. Zij volgde haar middelbare schoolopleiding aan de Scholengemeenschap Bataafse Kamp te Hengelo (O) en behaalde in 1975 haar eindexamen gymnasium alpha. Zij studeerde van 1975 tot 1979 Franse Taal- en Letterkunde aan de Rijks Universiteit Groningen. Vanaf 1979 studeerde zij Psychologie aan dezelfde universiteit, waar zij in 1985 haar doctoraal examen behaalde, met als afstudeerrichting Sociale Psychologie. Tijdens haar studie was zij student-assistent bij de vakgroepen Sociale Psychologie en Persoonlijkheidsleer. Van 1985 tot 1992 was zij als sociaalwetenschappelijk medewerker in dienst bij de Severinusstichting te Veldhoven. 